Entrepreneurs du commun
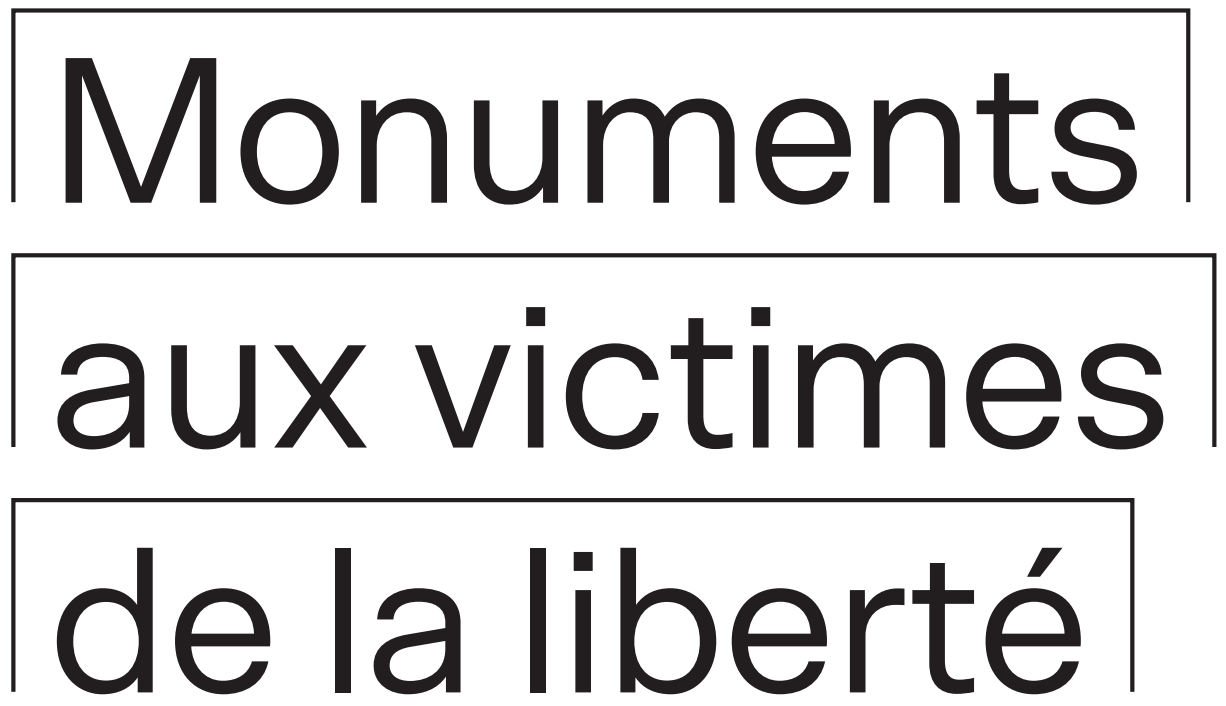
Cette publication rend compte des activités d'expositions, de symposium et de marche urbaine organisées autour du projet Monuments aux victimes de la liberté. Menées par le collectif Entrepreneurs du commun en partenariat avec la galerie AXENÉO7 et la Galerie UQO, ainsi que par des professeurs et étudiants de I'UQO, de I'Université Carleton et de l'Université d'Ottawa, ces activités ont eu lieu à Gatineau et Ottawa du 24 au 30 septembre 2015.

This publication revisits a series of exhibitions, symposium and urban walk events organized around the project Monuments to the Victims of Liberty. Steered by the collective Entrepreneurs du commun in partnership with AXENÉO7 gallery, UQO Gallery, as well as by professors and students from UQO, Carleton University and the University of Ottawa, the activities took place in Gatineau and Ottawa from September 24 to $30,2015$. 
Entrepreneurs du commun
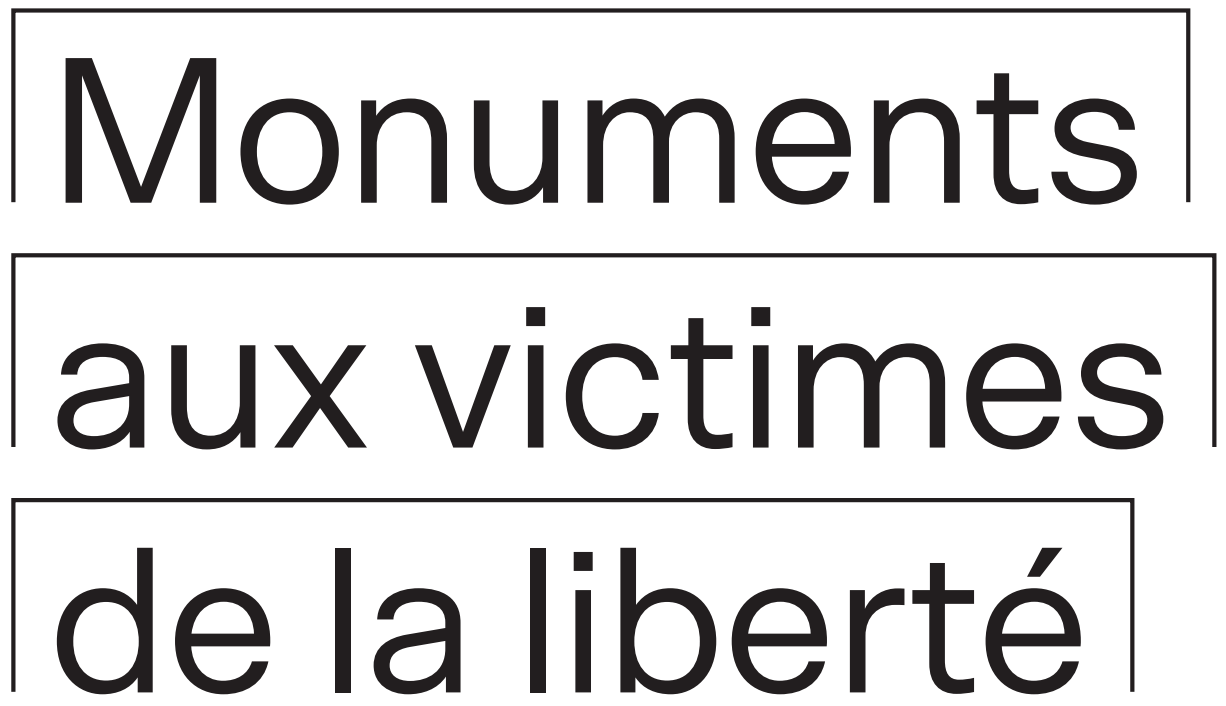


\section{Genèse du projet}

009

$$
\text { Introduction }
$$

Entrepreneurs du commun

017 Monuments massue

et monuments miroir

Nathalie Casemajor

029 Monuments aux victimes

de la liberté

Mélanie Boucher

Stefan St-Laurent

051 S'endormir près du monument pendant la révolution

Marie-Hélène Leblanc

063 Bojan Fajfrić

067 Milutin Gubash

071 Guillermo Trejo

075 Perspectives sur le commun,

la contre-monumentalité

et la décolonisation de la liberté

Bernard Schütze

Érik Bordeleau

089 Déambulations profanes

Peter Hodgins

Rebecca Dolgoy

Décoloniser la

\section{liberté canadienne}

103 Colonial Kitsch

Dalie Giroux

119 Clément de Gaulejac

127 Frank Shebageget

131 Sheena Hoszko

135 Michel de Broin

139 Dominique Sirois
Contre-monumentalité et post-communisme

147 Sites post-communistes de contre-mémoire

Andrew Herscher

159 Milutin Gubash

165 PROJETEVA

(Étienne Grenier et Simon Laroche)

171 Edith Brunette

177 Emmanuel Galland

Commun(isme)

185 Prises et entre-prises du commun Érik Bordeleau

201 Steve Giasson

209 Nicolas Rivard

215 Étienne Tremblay-Tardif

221 Anne-Marie Trépanier

Alexandre Piral

225 Thierry Marceau

\section{Annexes}

233 Notes

241 Biographies 


\section{Project Genesis}

013 Introduction

Entrepreneurs du commun

023 Brutalist Monuments

and Mirror Monuments

Nathalie Casemajor

037 Monuments to the Victims

of Liberty

Mélanie Boucher

Stefan St-Laurent

057 To Fall Asleep Close to the

Monument During the Revolution

Marie-Hélène Leblanc

063 Bojan Fajfrić

067 Milutin Gubash

071 Guillermo Trejo

081 Perspectives on the Commons,

Counter-Monumentality and

the Decolonisation of Liberty

Bernard Schütze

Érik Bordeleau

095 Profane Perambulations

Peter Hodgins

Rebecca Dolgoy

\section{Decolonizing}

\section{Canadian Freedom}

111 Colonial Kitsch

Dalie Giroux

Counter-Monumentality and Post-Communism

Post-Communist Sites

of Counter-Memory

Andrew Herscher

Milutin Gubash

PROJET EVA

(Étienne Grenier et Simon Laroche)

171 Edith Brunette

177 Emmanuel Galland

\section{Commun(ism)}

193 Gripping Enterprises of the Commons Érik Bordeleau

201 Steve Giasson

209 Nicolas Rivard

215 Étienne Tremblay-Tardif

221 Anne-Marie Trépanier

119 Clément de Gaulejac

Alexandre Piral

127 Frank Shebageget

131 Sheena Hoszko

Thierry Marceau

135 Michel de Broin

\section{Annexes}

139 Dominique Sirois 


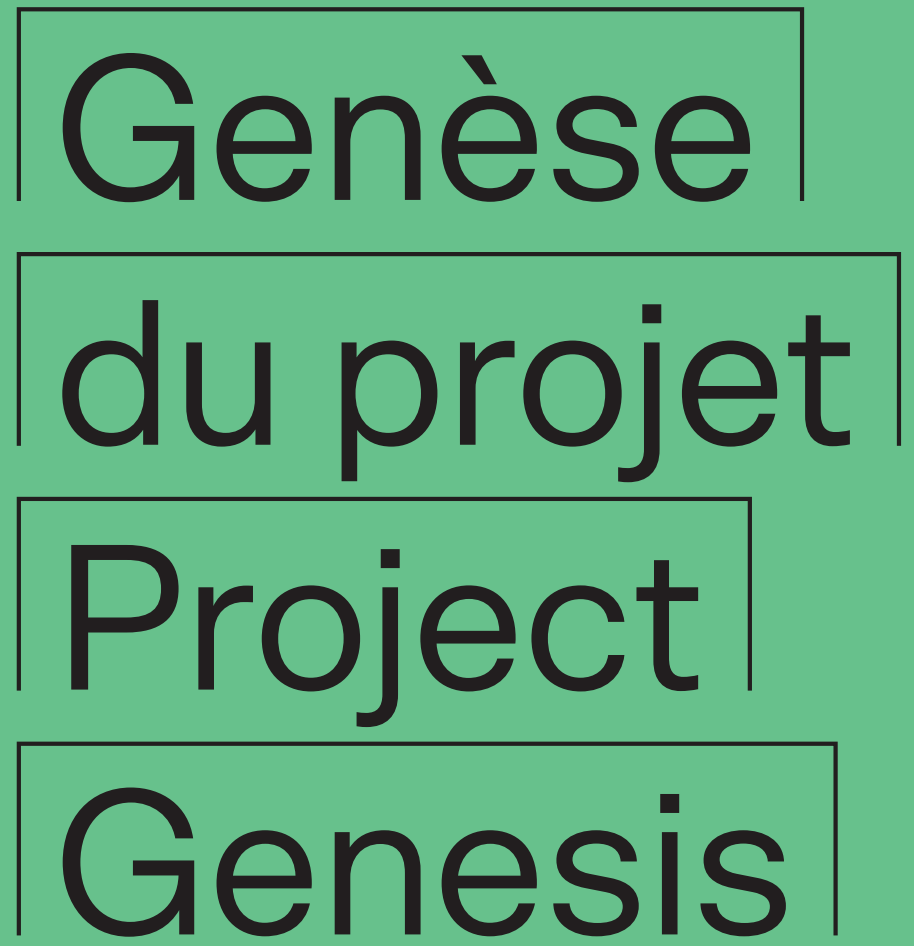



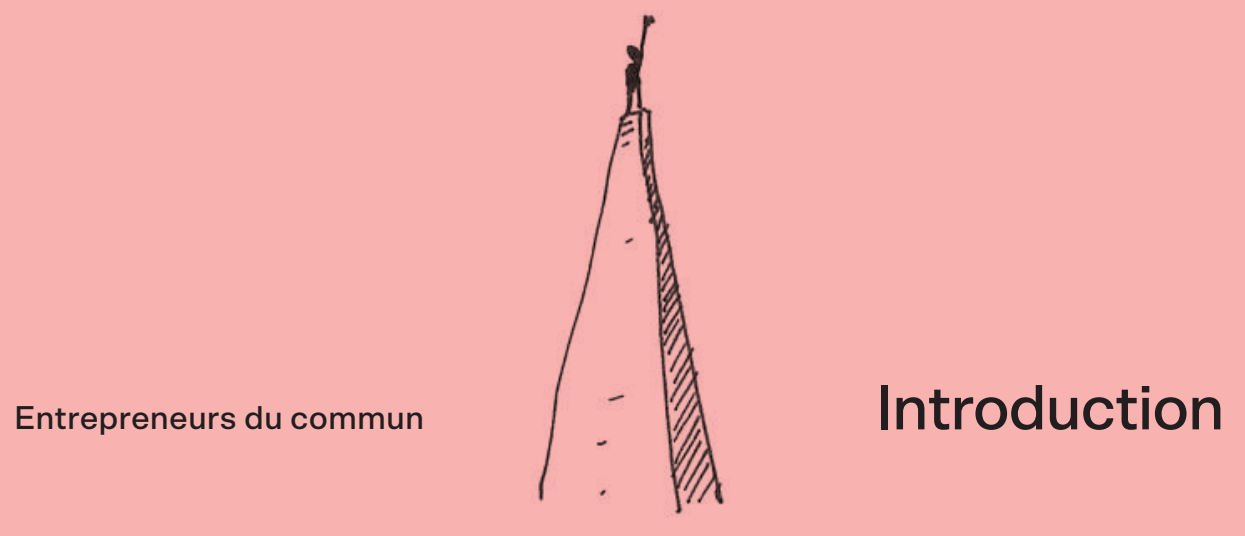



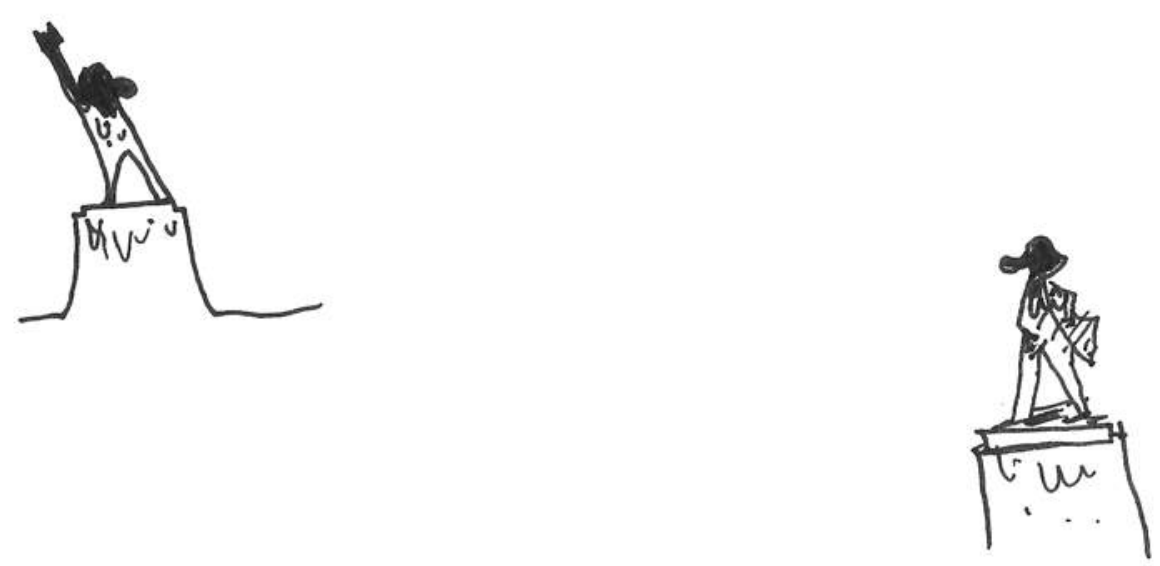

Au printemps 2014, le ministère du Patrimoine canadien a rendu public un appel à projet pour la construction d'un monument intitulé Monument aux victimes du communisme - Le Canada, une terre d'accueil. Le site prévu pour la construction du monument était adjacent à la Cour suprême*,en plein cœur de la colline parlementaire à Ottawa. L'appel invitait des équipes d'artistes professionnels, d'architectes, de paysagistes et autres professionnels du

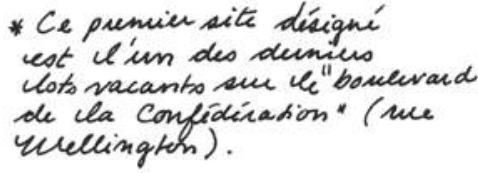
design urbain à participer au concours. Promu par une association nommée Hommage à la liberté, le monument visait à honorer la mémoire de «plus de 8 millions de Canadiens » originaires de "pays qui ont souffert sous des régimes communistes ${ }^{1} \gg$.

L'initiative d'Hommage à la liberté s'inscrit dans la continuité de la journée du Ruban noir, désignée journée nationale de commémoration des «victimes (du nazisme et ducommunisme), à la suite de l'adoption d'une résolution à cet effet par la Chambre des communes en 2009. Le Parlement européen a voté la même année une résolution instituant une journée d'hommage aux "victimes du stalinismet du nazisme ", rebaptisée plus sobrement depuis ... oupas "Journée européenne du souvenirh. Alors qu'en Europe, le glissement terminologique a ouvert la commémoration à l'ensemble des victimes des régimes totalitaires et autoritaires, quelle que soit leur idéologie (nazie, communiste ou fasciste), au Canada, sous le gouvernement Harper en particulier, le glissement a favorisé un rapprochement ciblé entre crimes nazis et crimes communistes. II ne s'agit plus alors de contextualiser les formes historiques spécifiques du communisme "totalitaire» ou "soviétique», mais de condamner d'un bloc l'idéologie communiste, dans une rhétorique partisane héritée de la Guerre froide. Ces conflits de définition témoignent des enjeux politiques qui sous-tendent l'instauration et la transformation des récits historiques dominants.

L'annonce du concours d'art public pour le Monument aux victimes du communisme est intervenue au crépuscule du règne du gouvernement Harper. Au Québec, le souvenir de la grève étudiante de 2012, marquée par des manifestations d'une ampleur inédite et par une importante mobilisation politique de collectifs artistiques dans le débat public, était encore vif. Sur la scène internationale tournaient en boucle des images de réfugiés 
du conflit syrien chassés à coups de pied de la frontière hongroise ${ }^{2}$, alors même que le gouvernement hongrois affichait son soutien à l'initiative canadienne visant à célébrer «le courage des victimes du communisme qui ont tout risqué » pour atteindre les frontières canadiennes «dans l'espoir de retrouver la liberté et leur dignité et de bâtir un nouvel avenir ${ }^{3}$ ". La Russie de Poutine manifestait ses velléités impériales, toujours vives, en annexant la Crimée et en réhabilitant la figure de Staline comme «homme fort » de l'empire. En Europe de l'Est et en Europe centrale, la mémoire des crimes nazis et soviétiques suscite encore aujourd'hui d'âpres débats : si les monuments à la gloire des "libérateurs" soviétiques sont jetés «à la orecharge de l'histoire" (Viktor louchtchenko), certains mouvements

Comme pour le monument... NOT VERY ABSTRAKT! ultranationalistes, notamment en Pologne, récusent la responsabilité de l'État dans les crimes perpétrés par les nazis pendant la Seconde Guerre mondiale ${ }^{4}$. En Amérique du Nord, ce sont des monuments à la mémoire de figures controversées de la confédération et du colonialisme qui sont déboulonnés, dans un mouvement s'opposant à la célébration publique de suprématistes blancs et de personnages impliqués dans des campagnes génocidaires contre les Premiers Peuples. La mémoire nationale est un champ de sables mouvants où vacillent les socles de marbre.
Pensons i" Anishinaabe Scout", utilí du reied de cea sculpture de samuel de Champlais. an dibut des 905 . Au Canada, le projet de monument s'inscrivait dans un contexte pré-électoral sur la scène fédérale. II était soutenu par la majorité des chefs des partis

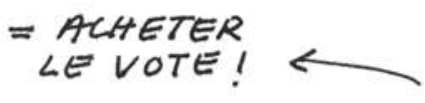
fédéraux ${ }^{5}$, conscients de sarésonance auprès de certaines communautés issues de l'immigration. Ce projet de monument s'est toutefois heurté au scepticisme de nombreux Canadiens : certains critiquant le choix de son emplacement, d'autres, sa charge idéologique, son lien ténu avec l'histoire du Canada, ou encore les pressions exercées sur les agences officielles ayant exprimé des réserves sur sa formulation ou sa gouvernance. Finalement, la mobilisation de la société civile et le changement de gouvernement ont mené à une révision en profondeur du projet de monument (nouveau site, réduction du financement, changement de design).

Le collectif Entrepreneurs du commun est né de cette mobilisation. II regroupe des commissaires, des artistes, des théoriciens et des universitaires du Québec et de l'Ontario. Avec son projet Monuments aux victimes

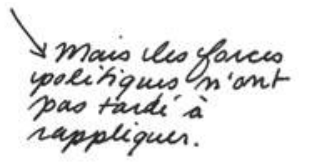


de la liberté, Entrepreneurs du commun proposait un contrepoint au projet de Monument aux victimes du communisme de l'association Hommage à la liberté. II en questionnait les paradoxes politiques et esthétiques : la «liberté canadienne $*$ a-t-elle aussi pu servir à justifier certains crimes liés * LIBERTAIRES
LIBERTINS R au colonialisme en sol canadien et à l'impérialisme à l'étranger? La diabolisation du communisme occulte-t-elle un renouvellement des pensées du commun? Peut-on faire acte de commémoration avec une œuvre éphémère ou anti-monumentale? Pour explorer ces contradictions internes, nous avons lancé un appel à projets calqué sur le format du concours d'art public.

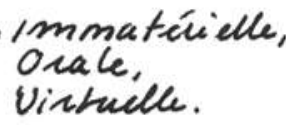
Une douzaine d'artistes se sont ainsi joints au projet. Des discussions ont été organisées à Montréal à l'invitation de la revue ESPACE art actuel et de la Galerie SBC.

Ce processus d'échange a culminé à l'automne 2015 avec une série d’activités 6 réalisées en collaboration avec d'autres organisations et col-? lectifs de Gatineau et d'Ottawa : deux expositions, une au centre d'artištes " AXENÉO7, et l'autre à la Galerie UQO; un symposium à l'Université du Québec en Outaouais; une marche urbaine sur la colline parlementaire à Ottawa proposée par un collectif d'universitaires et d'étudiants de l'Université Carleton. En proposant un espace temporaire d'organisation, de discussion, de recherche, de conférences et d'expositions, ce projet rejoint diverses initiatives menées par des collectifs en Europe et en Amérique du Nord, telles que Grupa Spomenik (Milica Tomič), Monument to Transformation 1989 - 2009 (Zbyněk Baladrán et Vít Havránek) et Monument to Cold War Victory (Committee for Tacit History).

Le présent ouvrage rend compte de ce processus d'échange. La première partie contextualise l'origine du projet et la série d'activités qui se sont déroulées à l'automne 2015, tandis que la seconde réunit des textes sur les œuvres réalisées ainsi que trois essais abordant les thèmes de la décolonisation de la liberté canadienne, de la contre-monumentalité et du post-communisme, et de la relation entre le commun et le transindividuel. 


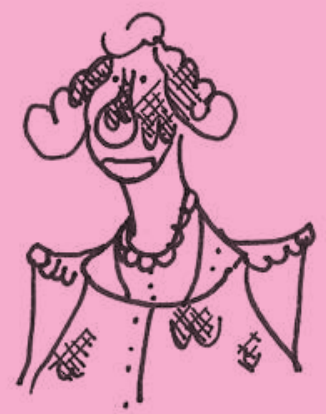




\section{Faka Colonial Boss}

In the spring of 2014, the Minister of Canadian Heritage launched a call for projects for the construction of a monument titled Memorial to the Victims of Communism-Canada, A Land of Refuge. The site set out for the construction of the monument was next to the Supreme Court, at the heart of Parliament Hill in Ottawa. The call invited professional artists and artist groups, architects, landscape architects and other urban design professionals to take part in the competition. The monument, which was promoted by a group called Tribute to Liberty aimed to honour the memory of "over 8 million people who trace their roots to countries that suffered under Communism." 1

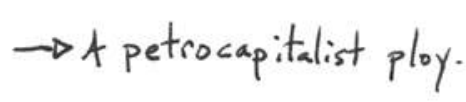

The Tribute to Liberty initiative is an extension of the Black Ribbon day, the designated national day of remembrance of "the victims of Nazism and communism," following the adoption of a resolution by the House of Commons in 2009. In the same year, the European Parliament voted a resolution to institute a day of remembrance for the "victims of Stalinism and Nazism," that has since been more soberly renamed the "European Day of Remembrance." Whereas in Europe, the terminological slippage opened the remembrance to all victims of totalitarian and authoritarian regimes, regardless of their ideology (Nazi, communist or fascist), in Canada, particularly under the Harper government, the slippage encouraged an intentional paralleling of Nazi and communist crimes. It is no longer about contextualizing the specific forms of "totalitarian" or "Soviet" communism, but about condemning communist ideology all together, in a partisan rhetoric inherited from the Cold War. This conflict of definitions points to the political stakes that underpin the instauration and transformation of hegemonic historical narratives.

The announcement of the public art competition for the Memorial to the Victims of Communism appeared at the twilight of the Harper regime. In Quebec, the memory of the 2012 student strike-marked by demonstrations of an unprecedented scale and a major political mobilization of artist collectives in public debate-was still vivid. On the international scene, news screens paraded endless image streams of Syrian refugees, who had been * violently kicked at the Hungarian border, ${ }^{2}$ while the Hungarian government 


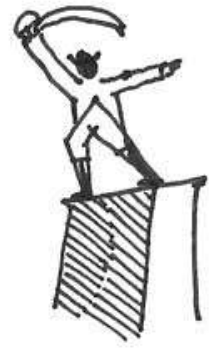

was expressing its support for the Canadian initiative seeking to celebrate "the courage of all victims of communism who risked everything to reach our borders in the hope of finding freedom, regaining their dignity and building a new future." ${ }^{3}$ In annexing Crimea and rehabilitating the figure of Stalin as a "strong man" of the empire, Putin's Russia was exhibiting enduring nationalist aspirations.

In Eastern and Central Europe, the memory of Nazi and Soviet crimes still triggers bitter debates: while the monuments to the glory of Soviet

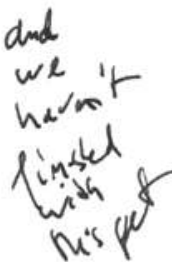
"liberators" have been thrown into "the garbage dump of history" (Viktor Yushchenko), some ultranationalist movements, notably in Poland, decline the State's responsibility in the crimes perpetrated by the Nazis during World War II. ${ }^{4}$ In North America it is the monuments commemorating the controversial figures of the Confederacy and colonialism that are taken down in a movement to counter public celebrations of white supremacists and figures involved in the genocidal campaigns against First Nations. Marble pedestals shake in the quicksand of national remembrance.

In Canada, the project for a memorial was part of a pre-electoral context on the international stage. It was supported by the majority of federal parties ${ }^{5}$ due to its resonance among certain immigrant communities. However, the memorial project was met with skepticism by many Canadians: some criticized the choice of site, others its ideological charge or its weak link to Canadian history; and others the pressure exerted by official agencies that had expressed reservations regarding the project's formulation or governance. Finally, mobilization on the level of civil society and a change $1 \rightarrow$ Revealing itt. in government led to an in-depth revision of the memorial project (a new site, diminished funding, and change of design).

The Entrepreneurs du commun collective was born of this mobilization. It brought together curators, artists, theorists and academics from Quebec and Ontario. With its project Monuments to the Victims of Liberty, Entrepreneurs du commun proposed a counterpoint to the Memorial to the Victims of Communism promoted by the Tribute to Liberty group. It called its political and aesthetic paradoxes into question: has "Canadian freedom" not served to justify certain crimes linked to colonialism on Canadian soil 
and to imperialism abroad? Does the demonization of communism obscure renewed ways of thinking the commons? Can commemoration take place through an ephemeral or anti-monumental work? To explore these inherent contradictions, we launched a call for projects by adopting a typical public art competition format. A dozen artists joined the project. Discussions were organized in Montreal at the invitation of magazine ESPACE art actuel and SBC Gallery of Contemporary Art.

In the fall of 2015, this process culminated with a series of activities carried out in collaboration with other organizations and groups in Gatineau and Ottawa: two exhibitions, one at the artist-run centre AXENÉO7, and the other at the Galerie UQO; a symposium at Université du Québec en Outaouais; an urban walk around Parliament Hill proposed by a collective of professors and students from Carleton University. ${ }^{6}$ In providing a temporary organization, discussion, research, conference and exhibition space, this project echoes various initiatives carried out by collectives in Europe and North America, such as Grupa Spomenik (Milica Tomič), Monument to Transformation 1989

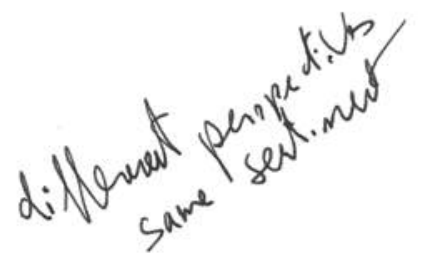
- 2009 (Zbyněk Baladrán and Vít Havránek) and Monument to Cold War Victory (Committee for Tacit History).

This book bears witness to this process of exchange. The first part traces the origins of the project and the series of activities that unfolded over the fall of 2015. Whereas the second presents texts on the works that were created in response to the call for projects, as well as three essays that respectively analyze the themes of decolonization of Canadian liberty, counter-monuments and post-communism, and the relation between the common and the transindividual. 
Dans le parc d'un centre communautaire de Scarborough, en banlieue de Toronto, se tient un monument aux victimes de l'oppression soviétique en Tchécoslovaquie. Érigé en 1989, Crucified again prend la forme d'un homme de bronze crucifié sur une faucille et un marteau. Il commémore la mémoire des victimes d'exécution, d'emprisonnement et de répression politique sous le règne du parti communiste (1948-1989). C'est devant cette statue, lors d'une conversation tenue à l'été 2007, que le journaliste Don Butler ${ }^{7}$ situe la naissance du projet Monument aux victimes du communisme. John Kenney, alors secrétaire parlementaire du premier ministre Stephen Harper, était en visite auprès de l'ambassadeur de la République tchèque. Harper lui avait donné pour mission d'attirer vers le Parti conservateur les communautés ethnoculturelles que le Parti libéral avait su courtiser. Frappé par l'intérêt du monument pour sa mission, Kenney suggéra d'étendre l'initiative, et l'ambassadeur aurait cité Ottawa comme lieu tout indiqué pour l'érection d'un nouveau monument.

Le Monument aux victimes du communisme devait être inauguré à l'automne 2015, juste avant l'élection fédérale, mais une controverse en a retardé la construction. Un vif débat s'était engagé en 2014, dès l'annonce du concours d'architecture et du choix de son emplacement : un site prestigieux au cœur de la colline parlementaire, face à la Cour suprême. Un site hautement symbolique du principe de justice, puisqu'il fait partie d'un plan architectural de «triade judiciaire». Le bâtiment administratif qui devait y être construit portait le nom de Pierre Elliott Trudeau, ancien premier ministre libéral et adversaire des conservateurs.

À l'approche de l'élection, les tensions qui couvaient depuis plusieurs années entre le gouvernement et la Commission de la capitale nationale, chargée d'approuver tout nouveau projet de monument, se sont exacerbées. L'autonomie de la Commission et le contrôle de sa gouvernance ont été éprouvés à plusieurs reprises. Au cours du processus, plusieurs ministres sont intervenus directement auprès du conseil d'administration de la Commission dans l'espoir de faire changer le titre et l'emplacement prévu du monument. Les modifications apportées au titre témoignent de ce bras de fer : la Commission exigea d'inclure la mention Le Canada, une terre d'accueil 
afin d'élargir le thème à tous les réfugiés de régimes oppressifs, sans cibler les régimes communistes; l'épithète " totalitaire" fut quant à lui ajouté au terme communisme sur la recommandation d'un comité d'historiens, puis retiré sous la pression du gouvernement. Le choix du design architectural, arrêté par le ministre du Patrimoine, fut lui aussi critiqué. De style brutaliste, la proposition du cabinet ABSTRAKT, que certains commentateurs ont ironiquement qualifié de "totalitaire», consistait en une immense photographie de charnier sur une structure massive en béton.

Plusieurs enjeux se croisent dans cette controverse. Celui de la lutte entre partis politiques pour les votes communautaires et le prestige symbolique. Celui de l'aménagement urbain de la colline parlementaire. Celui de l'esthétique monumentale. Celui de la portée politique du monument comme outil de construction d'une mémoire nationale. Et celui de l'affrontement idéologique entre capitalisme et communisme après la chute du bloc soviétique. Cependant, l'enjeu de l'aménagement urbain s'est imposé comme thème central du débat dans les médias, entre les candidats politiques ainsi que dans le discours des coalitions opposées au monument. À quelques exceptions près, l'enjeu idéologique est resté marginal dans les prises de parole officielles. Pourtant, il ressurgissait systématiquement dans les commentaires postés par les internautes sur les médias en ligne ${ }^{8}$. Refoulé aux marges de l'espace public, plus risqué à manipuler, l'enjeu idéologique était pourtant la cause inavouée du malaise.

Dans une exposition collective intitulée Monument to the Cold War Victory (2014, Cooper Union, New York), les commissaires Stamatina Gregory et Yevgeniy Fiks se sont penchés sur l'implicite constat de victoire du bloc occidental à l'issue de la Guerre froide. Parmi les œuvres réunies, la sculpture Mesomemorial: March of Victory du collectif franco-hongrois Société Réaliste présentait une forme hybride résultant de l'amalgame de deux monuments de la place Szabadság tér (place de la Liberté), au centre de Budapest. Les artistes ont utilisé un algorithme pour combiner la forme d'une sculpture commémorant la victoire de l'Armée rouge sur les troupes nazies et celle d'un buste de Ronald Reagan. L'œuvre déjoue ainsi l'opposition binaire entre communisme et capitalisme et entre liberté et oppression. 
Le Monument aux victimes du communisme d'Ottawa repose au contraire sur une conception essentialisante et réductrice des idéologies politiques. D'un côté, le communisme est défini comme étant totalitaire par essence, d'où le retrait du terme dans le titre, car sa présence aurait suggéré l'existence d'une pluralité de formes de communismes, dont certains sont totalitaires et d'autres, des vecteurs d'émancipation. Sur l'autre versant de cet affrontement idéologique, le capitalisme est implicitement défini comme libérateur et démocratique par essence (le groupe initiateur du projet de monument se nomme Hommage à la liberté), éludant ainsi le potentiel totalitaire de certaines formes de capitalisme.

Le corollaire de cette démarche essentialiste est de maintenir comme point aveugle la relation interne entre l'histoire du communisme et l'histoire du Canada. Le communisme y est relégué à un statut externe : une force politique étrangère qui a causé l'exil de nombreuses personnes ayant trouvé refuge au Canada. Or il existe une histoire canadienne du communisme (et de l'anticommunisme) plus complexe et plus ambiguë que ne le suggère le discours sur les crimes étrangers. Une histoire qui comporte aussi des atteintes aux libertés civiles en sol canadien, au nom de la lutte contre l'idéologie communiste (loi du cadenas, répression contre les mouvements ouvriers et syndicaux, "tests d'homosexualité " sur des fonctionnaires potentiellement exposés au chantage d'ennemis communistes).

Enfermé dès son origine dans des logiques de partisanerie politique-et évitant ainsi le malaise du regard sur soi-même-, le monument canadien échoue à prendre en compte la complexité de l'histoire. D'autres ont su exprimer davantage ce trouble. À Liberec, en République tchèque, le collectif d'architectes Sporadical a inauguré en 2006 un Monument aux victimes du communisme qui prend la forme d'un monolithe de miroir. Dans le reflet se lit une invitation à l'introspection, à l'examen de nos rôles respectifs en tant que victimes et bourreaux. 


\section{Chronologie}

\section{7}

Genèse du Monument aux victimes du communisme à la suite d'une rencontre entre Jason Kenney (futur ministre de la Citoyenneté, de l'Immigration et du Multiculturalisme sous le gouvernement Harper) et Pavel Vosalik, ambassadeur de la République tchèque au Canada.

\section{8}

Le groupe Hommage à la liberté soumet le projet de monument à la Commission de la capitale nationale.

\section{9}

Un comité d'experts recommande la modification du titre. Approbation du projet par la CCN sous le titre Monument aux victimes du communisme totalitaire - Le Canada, une terre d'accueil.

\section{0}

Attribution d'un emplacement pour le monument au Jardin des provinces et des territoires, en périphérie de la colline parlementaire.

\section{2}

Changement d'emplacement pour un lot adjacent à la Cour suprême, au cœur de la colline parlementaire. À la suite d'une intervention gouvernementale, le terme «totalitaire » est retiré du titre.

\section{4}

L'architecte Barry Padolsky lance une mobilisation contre le choix du nouvel emplacement. Mise sur pied d'un concours et sélection du design proposé par la firme d'architecture ABSTRAKT.

\section{5}

Dans la foulée de l'élection du Parti libéral, la nouvelle ministre du Patrimoine canadien, Mélanie Joly, annonce des changements au projet, soit le lancement d'un nouveau concours de design, la réduction du budget et le retour au site original.

\section{7}

Sélection du nouveau design, L'Arc du souvenir, proposé par l'équipe de l'architecte Paul Raff. 

Nathalie Casemajor

In collaboration with Rosa Iris R. Rovira

\section{Brutalist Monuments and Mirror Monuments}


In the community centre of Scarborough, a suburb of Toronto, there is a monument to the victims of Soviet oppression in Czechoslovakia. The monument, Crucified again, which was erected in 1989, shows a man in bronze crucified on a hammer and sickle. It commemorates the victims of executions, imprisonment and political repression during the reign of the Communist Party (1948-1989). According to the journalist Don Butler, the Canadian Memorial to the Victims of Communism originated as a conversation held in front of this sculpture during the summer of 2007.7 John Kenney, Stephen Harper's parliamentary secretary at the time, was visiting the Czech Republic embassy. Harper had given him the mission to make the Conservative party attractive to the ethno-cultural communities that the Liberal Party had successfully wooed in the past. Struck by the interest of the monument for his mission, Kenney suggested to widen the initiative and the ambassador apparently cited Ottawa as a perfect fit for the construction of a new monument.

The Memorial to the Victims of Communism initially intended to be inaugurated in autumn 2015, just before the federal election, but controversy delayed its construction. A heated debate emerged in 2014, immediately following the announcement of the architecture competition and the location of the chosen location: a prestigious site at the centre of Parliament Hill, across from the Supreme Court. The location is highly symbolic of the principle of justice because of its deliberate placement in the "judicial triad" architecture plan. Up until that point in time, the site had also been reserved for the construction of an administrative building that was to be named after Pierre Elliott Trudeau, a former Liberal Prime Minister and adversary of the Conservatives. The impending elections exacerbated the tensions that had been simmering for several years between the government and the National Capital Commission, which is responsible for the approval of any new monument. The independence and governance of this Commission was put to the test several times. Over the course of the project's preparation process, several ministers directly approached the Commission's Board to change the chosen title and site for the memorial. The subsequent modifications that were made to the title of the monument 
testify to this war of words: the Commission required that the subtitle Canada, a Land of Refuge be added to broaden the theme and include all refugees of oppressive regimes, without specifically singling out communist ones. As for the epithet "totalitarian," it was added to the term communism on recommendation of a committee of historians, and subsequently removed due to pressure from the government.

The choice of architectural design settled on by Heritage Canada was also criticized. ABSTRAKT cabinet proposed a Brutalist style project-ironically described as "totalitarian" by some observers - that consisted of an immense photograph of a mass grave on a massive cement structure.

This controversy overlaps several issues: the battle between political parties to win votes in identified communities and garner symbolic prestige; urban planning on Parliament Hill; the aesthetics of monument representation; the political reach of the monument in the construction of national memory; and the ideological showdown between capitalism and communism after the fall of the Soviet bloc. However, the issue of urban planning emerged as the central theme in mediatized debates, in the battles between political candidates and in the discourses of groups who were opposed to the memorial. Except for very few exceptions, ideological questions remained marginal in the official debates and political jockeying. Yet it systematically resurfaced in the comments posted in online media by internet users. ${ }^{8}$ Even though the hot button ideological issues were pushed to the margins of public space, they remained the unspoken cause of the malaise.

In a group exhibition called Monument to the Cold War Victory (2014, Cooper Union, New York), the curators Stamatina Gregory and Yevgeniy Fiks focused on the implicit sense of victory of the Western Bloc at the end of the Cold War. Among the exhibited works, Mesomemorial: March of Victory by the Franco-Hungarian group Société Réaliste presented a hybrid shape resulting from the merging of two sculptures at Szabadság tér square in the centre of Budapest. The artists used an algorithm to combine a memorial sculpture of the Red Army's victory over the Nazis and a bust of Ronald Reagan. The work thus thwarts the binary opposition between communism and capitalism, between liberty and oppression. 
The Ottawa Memorial to the Victims of Communism is, on the contrary, based on an essentialist and reductionist understanding of political ideology. In one regard, communism is defined as being totalitarian in essence, hence the removal of the term "totalitarian" in the title, because its presence could have suggested a plurality of communisms, including certain totalitarian ones as well as others that hold a promise of emancipation. On the other side of this ideological confrontation, capitalism is implicitly defined as being liberating and democratic in essence (the group which initiated the project is called Tribute to Liberty) and thus elides the totalitarian potential of certain forms of capitalism.

The corollary of this essentialist approach is the maintenance of blindness towards the internal relationship between the history of communism and the history of Canada. Communism is relegated to the status of an external entity: a foreign political force that causes the exile of many people who have found refuge in Canada. Yet there is a Canadian history of communism (and anti-communism) that is more complex than is suggested by the discourses about foreign crimes. A history that also has its lot of civil liberties infringements on Canadian soil enacted in the name of a struggle against communism (i.e. the Padlock Law; repression against labour and union movements; "homosexuality tests" of civil servants that could potentially be exposed to blackmail by communist enemies).

From the very start, the Canadian memorial was locked into the logic of political partisanship and thus avoiding the unease of having to look at itself, and thus failed to take the complexity of history into account. Others have had more success in expressing this problem. In 2006, at Liberec in the Czech Republic, the architectural firm Sporadical inaugurated a Monument to the Victims Communism in the shape of a monolith mirror. The reflection can be read as an invitation to introspection, to examine our own roles as victims and executioners. 


\section{Chronology}

\section{7}

Genesis of the Memorial to the Victims of Communism following a meeting between Jason Kenney (future Minister of Citizenship, Immigration and Multiculturalism under the Harper government) and Pavel Vosalik, ambassador of the Czech Republic in Canada.

\section{8}

The Tribute to Liberty group submits the memorial project to the National Capital Commission (NCC).

\section{9}

A committee of experts recommends a modification to the title. Approval of the project by the NCC under the title of Memorial to the Victims of Totalitarian Communism-Canada, a Land of Refuge.

\section{0}

Designation of a site for the memorial at the Garden of Provinces and Territories on the outskirts of Parliament Hill.

\section{2}

Change of site for a lot adjacent to the Supreme Court at the heart of Parliament Hill. Following an intervention by the government, the term "totalitarian" is removed from the title.

\section{4}

The architect Barry Padolsky begins mobilization against the choice of the new site. Setting up of a competition and selection of the design proposed by the architecture firm ABSTRAKT.

\section{5}

In the wake of the Liberal Party's election, the new Minister of Canadian Heritage, Mélanie Joly announces changes to the project, i.e. the launch of a new design competition, budget reduction and a return to the original site.

\section{7}

Selection of the new design, The Arc of Memory by the architect Paul Raff. 



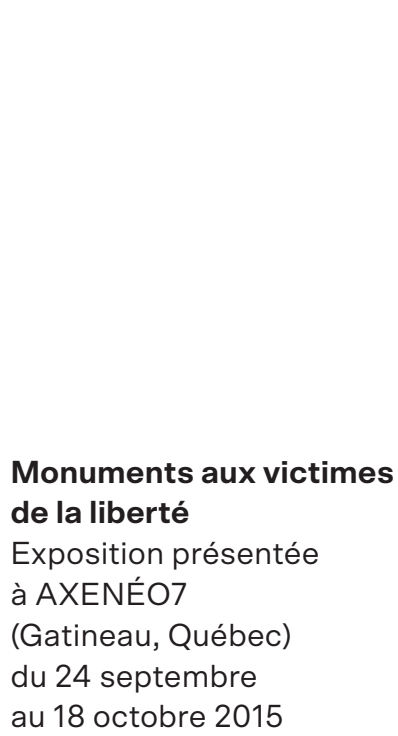

\section{Artistes}

Edith Brunette

Michel de Broin

Clément de Gaulejac

Emmanuel Galland

Steve Giasson

Milutin Gubash

Sheena Hoszko

Thierry Marceau

Projet EVA

(Étienne Grenier et Simon Laroche) Nicolas Rivard

Frank Shebageget

Dominique Sirois

Étienne Tremblay-Tardif Anne-Marie Trépanier et Alexandre Piral

\section{Commissaires}

Mélanie Boucher

Nathalie Casemajor

André-Louis Paré

Bernard Schütze

pour les Entrepreneurs

du commun 
À l'été 2014, notre groupe composé d'artistes, de chercheurs et de travailleurs culturels se réunissait pour la première fois sous le nom d'Entrepreneurs du commun, en réponse au projet critiqué de Monument aux victimes du communisme. Nous en appelions aux artistes en arts visuels à réagir aux interrogations suivantes : qui sont les victimes de la liberté? La liberté n'est-elle pas le prétexte de nombreux conflits menés depuis plusieurs années? Existe-t-il des totalitarismes de la liberté? Si la liberté n'est pas une marque de yogourt (comme le dit Pierre Falardeau), qu'en est-il de l'appellation contrôlée « liberté canadienne », dont parle Stephen Harper? Qu'est-ce que le communisme, et pourquoi en parler aujourd'hui? En quoi concerne-t-il le renouvellement actuel des pensées du commun?

L'invitation lancée sous forme d'appel à projets avait pour objectif la sélection de six ou sept propositions convaincantes, en vue de l'exposition qui s'est tenue du 24 septembre au 18 octobre 2015 au centre d'artistes AXENÉO7 9 . Nous espérions alors surtout nous faire entendre et recevoir suffisamment de propositions pour faire une «bonne exposition » réunissant des œuvres significatives et cohérentes entre elles. L'appel avait bien circulé dans nos réseaux, mais notre collectif qui était alors inconnu n'offrait que très peu de choses; une intention et un lieu d'exposition, sans cachet garanti pour la production ou la diffusion. Nous avons néanmoins reçu près de 30 propositions, la plupart fort intéressantes, ce qui révèle, pensons-nous, l'engagement politique et social des artistes québécois et canadiens. Au final, nous n'avons pas limité notre choix à six ou sept propositions, mais en avons sélectionné près du double ${ }^{10}$. Et les artistes invités ont accepté de produire bénévolement leur nouvelle œuvre. Nous leur avons promis en retour de chercher activement du financement et leur avons donné une voix au sein du collectif.

La production de l'exposition connut bien sûr ses hauts et ses bas. La transparence du travail à laquelle nous tenions à chacune des étapes administratives et expographiques fut toutefois récompensée. La prémisse selon laquelle les individus présents aux réunions avaient un droit décisionnel ne pouvant pas être remis en cause par les absents facilita grandement l'avancement du projet. L'équipe commissariale formée de Mélanie Boucher, Nathalie Casemajor, André-Louis Paré et Bernard Schütze contribua également à la mise en œuvre d'une vision concertée et à la répartition efficace des tâches. 
Entre l'obtention d'une subvention du Conseil des arts du Canada à la fin juin et l'ouverture de l'exposition à la fin septembre, nous avons disposé de seulement trois mois pour préciser la teneur des œuvres et les exigences requises. La subvention couvrait pour l'essentiel les frais de production et de diffusion. Le montage de l'exposition s'est fait en six jours bien remplis, aboutissement d'un an de travail réactif et proactif effectué dans l'urgence de la riposte. Le texte d'introduction en grosses lettres noires sur un mur blanc avait l'allure d'un manifeste. Le collectif et les objectifs de l'exposition y étaient décrits comme suit :

Un Monument national canadien aux victimes du communisme sera prochainement érigé à Ottawa, sur un site adjacent à la Cour suprême du Canada. La décision du gouvernement canadien actuel d'appuyer cette initiative commémorative privée et d'assurer son importance par un soutien politique et monétaire hors normes est à l'origine de cette exposition qui regroupe des $œ u v r e s$ qui remettent en question l'instrumentalisation idéologique du concept de liberté que sous-tend cet appui contestable du gouvernement canadien. Les œuvres portent, entre autres, sur la capture idéologique du principe de liberté, sur le sens et la portée de l'acte commémoratif, sur l'opposition entre le capitalisme et le communisme, sur les droits et libertés, sur les systèmes d'incarcération ainsi que sur la mémoire des minorités. Chacune à leur manière, elles forment une réponse critique, formelle et conceptuelle au Monument national canadien aux victimes du communisme. Elles sont ici exposées en galerie de même que dans les espaces de circulation et à l'extérieur.

Les œuvres ont été réalisées par des artistes canadiens appartenant à différentes générations ainsi qu'à différentes communautés. Ces œuvres, pour la plupart inédites, ont été retenues par le collectif Entrepreneurs du commun à la suite d'un appel de propositions. Cet appel invitait les artistes du domaine des arts visuels à soumettre des propositions de contre-monuments en hommage aux victimes de la liberté. Les contre-monuments emploient des stratégies inverses à celles des monuments conventionnels, que ce soit par le sujet traité, la forme, le site d'implantation, l'expérience suscitée ou la signification. 
L'idée de contre-monumentalité a été intégrée au projet et présentée avant l'ouverture de l'exposition dans les communications publiques d'Entrepreneurs du commun - une table ronde organisée par la revue ESPACE art actuel. Pratiques et perspectives (le 25 novembre 2014), un Talk Show mis sur pied par la Galerie SBC (le 28 février 2015, dans le cadre de la Nuit blanche à Montréal), ainsi que l'événement Art et politique présenté par Arts Cultures Théories Expérimentations et le Laboratoire Art et Politique (le 23 mars 2015, à la Cinémathèque québécoise). De plus, le dossier du numéro 112 (Hiver 2016) de la revue ESPACE, intitulé "Monuments et contre-monuments » a été impulsé par trois membres du comité de rédaction, également membres du collectif - la sortie du numéro a succédé à la tenue de l'exposition.

Un monument, comme le rapporte le Vocabulaire d'esthétique, est une sculpture, une œuvre d'architecture qui a pour fonction de conserver la mémoire de quelqu'un ou de quelque chose. Cette production pérenne constituée de matériaux durables est destinée à rappeler et à entretenir la mémoire collective. Elle doit être située dans un espace public fréquenté et avoir un lien étroit avec l'objet du souvenir (incluant le site et la communauté). Le monument possède une valeur commémorative, une valeur historique et, avec le temps, il acquiert une valeur d'ancienneté (plus il est vieux, plus il gagne en importance), comme l'a écrit Aloïs Riegl dans son étude épistémologique Le culte moderne des monuments, publiée en 1903. Le contre-monument, quant à lui, remet en question les valeurs entretenues par le monument. II remet en question sa place dans l'espace public, son emploi idéologique ainsi que les histoires qu'il occulte par la consécration d'une histoire figée dans le bronze ou la pierre, comme l'a d'abord démontré James E. Young. Réactif et critique, le contre-monument rejette et renégocie les raisons de la commémoration. II ouvre et multiplie les perspectives sur les sujets considérés. II revisite aussi les formes monumentales en remettant en cause les matériaux (nobles, durables), les volumes (érigés, imposants), les sites d'implantation (stratégiques, hautement aménagés). L'idée longtemps maintenue d'implanter le Monument aux victimes du communisme sur un site adjacent à la Cour suprême du Canada exemplifie de manière frappante 
le rapport entre l'idéologie et la valeur existante d'un site. Par opposition, le contre-monument sera peu visible. II exploitera plutôt les creux et les contre-formes, et il invitera à la participation plus qu'il n'imposera le respect. En somme, il prendra à contre-pied l'effet monumental.

Les artistes de l'exposition Monuments aux victimes de la liberté ont présenté des contre-monuments. Leurs œuvres ont apporté des réponses critiques au Monument aux victimes du communisme, et plusieurs ont exploité les stratégies formelles de la contre-monumentalité. Déployée dans les trois salles d'AXENÉO7, dans les espaces publics de la Filature (qui abrite aussi DAÏMÔN et des ateliers d'artistes) ainsi qu'à l'extérieur, l'exposition a été conçue de manière à établir des dialogues ouverts et féconds entre les œuvres et l'environnement.

La première salle regroupait les œuvres performatives et participatives qui exploitaient le plan et la maquette. Le groupe EVA a présenté des maquettes de monuments miniatures, des négatifs de la proposition qui avait été retenue pour le projet Monuments aux victimes de la liberté. Le concept consistait à produire des miniatures qui, désignées du nom d'individus décédés dans des pays démocratiques par la faute des autorités en place, s'emboitaient de façon à «disparaitre ». Ces «souvenirs » devaient être vendus par le collectif à proximité du Monument. En face de ce projet exploitant l'alignement, l'œuvre d'Edith Brunette révélait le pouvoir de l'intervention furtive : mettre en terre des semences des quatre coins du monde sur le gazon parfait du site du monument afin que les brins d'herbe ne soient plus identiques. L'effet subtilement perturbateur de ce projet d'intervention trouvait un écho dans l'accrochage en salle (rythmé, avec tablettes, cadres et plantes véritables). Entre ces deux pôles figurait le plan du monument contestataire d'Emmanuel Galland. La proposition se composait des lettres N.O.N. pouvant être portées d'un site à l'autre, au gré des événements. L'œuvre d'Anne-Marie Trépanier et d'Alexandre Piral était présentée extra-muros et sur le Web. Implanté sur trois sites, leur monument «à écrire» sollicitait l'apport des internautes afin de créer un récit à voix multiples.

La salle attenante réunissait les productions de Frank Shebageget, Michel de Broin, Nicolas Rivard et Steve Giasson. Dans cette salle à la sombre 
esthétique, où dominaient les noirs et les blancs, était rattachée une idée du renversement plus prégnante qu'ailleurs dans l'exposition. Shebageget y a révélé au grand jour l'histoire oblitérée des Inuits et des Métis par l'énumération sur papier goudronné des noms des 719 communautés du Canada qui sont en processus de réappropriation de leur langue, de leur culture et de leur territoire. De Broin a érigé sur un socle de hauteur démesurée un nœud de destruction composé de mains prenant les armes. Sa sculpture figurait un massacre susceptible de tout détruire, y compris soi-même. Nicolas Rivard a entrepris pour sa part de lister méthodiquement chacune des décisions du gouvernement canadien à l'origine du projet Monument aux victimes du communisme. Son travail de recherche-création a permis de mettre en mots et en images l'ignominie d'une autorité qui se donne le droit de dénoncer autrui. Steve Giasson, enfin, a traité de l'appropriation du communisme par le capitalisme (qui se définit pourtant comme son contraire) par l'association d'idées, d'images et d'objets a priori antinomiques. En outre, il a superposé des images vidéo du cercueil de verre du chef-d'œuvre Blanche-Neige et les sept nains, de Disney, et de celui de Lénine. Il a également présenté des exemplaires du Manifeste du parti communiste, de Karl Marx et Friedrich Engels, achetés sur le site Internet de l'entreprise américaine multinationale Walmart.

La troisième salle, face aux deux autres, réunissait deux œuvres qui traitent d'incarcération. Sheena Hoszko a reproduit à l'échelle une cellule d'isolement typique du Canada. Cet espace de dimension restreinte interrogeait la notion de torture. L'œuvre rappelait étrangement l'art minimaliste. Tout près, Thierry Marceau personnifiait en vidéo John Wayne Gacy, dans un récit épique se jouant de la culture populaire. Gacy était un meurtrier en série qui, dans l'attente de son procès, et éventuellement de son exécution, a peint dans sa cellule des toiles de goût douteux qui ont été vendues à prix fort.

Six œuvres de Clément de Gaulejac longeaient les murs des couloirs menant aux trois salles d'exposition. De Gaulejac, dont les affiches créées au cours du printemps érable alimentaient une critique de l'actualité, a produit pour la présente exposition cinq affiches, avec pour tête de Turc Stephen Harper, ainsi qu'une miniature de la statue de la Liberté sous forme de boite à 
musique. La boite actionnée jouait l'Internationale. Exploitant l'irrévérence, les œuvres de Clément de Gaulejac établissaient un lien entre les productions en galerie et celles qui étaient montrées dans les lieux publics. Dans l'espace central de la Filature gisait un homme tenu pour mort. Son corps de plâtre était accompagné d'un sac de couchage imprimé de graphiques dressant un profil de la pauvreté. Non loin de cette installation de Dominique Sirois, l'œuvre d'Étienne Tremblay-Tardif se faisait entendre. Des voix tissaient le réseau d'influences du Monument aux victimes du communisme; dans les toilettes, à demi-mots, derrière les portes closes, pour un groupe d'initiés, étions-nous amenés à penser. À l'extérieur, sur un des murs arrière de la Filature, Milutin Gubash a installé une plaque commémorative. Cette plaque à la mémoire des immigrants rend hommage au monument absent. Elle est toujours en place. 
Monuments to the Victims of Liberty An exhibition presented at AXENÉO7 (Gatineau, Québec) from September 24 to October 18, 2015

\section{Artists}

Edith Brunette

Michel de Broin

Clément de Gaulejac

Emmanuel Galland

Steve Giasson

Milutin Gubash

Sheena Hoszko

Thierry Marceau

Projet EVA

(Étienne Grenier and Simon Laroche) Nicolas Rivard

Frank Shebageget Dominique Sirois

Étienne Tremblay-Tardif Anne-Marie Trépanier and Alexandre Piral

\section{Curators}

Mélanie Boucher Nathalie Casemajor André-Louis Paré and Bernard Schütze for the Entrepreneurs du commun 
During the summer of 2014, in response to the controversial Memorial to the Victims of Communism project, our group, made up of artists, researchers and cultural workers, met for the first time under the name Entrepreneurs du commun. We called on visual artists to respond to the following questions: who are the victims of liberty? Is liberty not a pretext for numerous conflicts that have been raging for many years? Are there totalitarian forms of liberty? If liberté is not a brand of yogurt (as the Quebec filmmaker Pierre Falardeau said) what then is one to make of the trademark "Canadian liberty" Stephen Harper talked about? What is communism and why talk about it today? How does it pertain to the current renewal of reflections about the commons?

The goal of the invitation, which was launched as a call for projects, was to make a selection of six or seven convincing propositions for the purposes of the exhibition that was held from September 24 to October 18, 2015 at the artist-run centre AXENÉO7. ${ }^{\circ}$ At the time our hope was primarily to be heard and to receive enough propositions to put on a "good show" consisting of a coherent grouping of significant works. The call was broadly disseminated in our respective networks, but our collective, still unknown at the time, could not offer much: an objective and an exhibition site without guaranteed production or dissemination fees. We nevertheless received 30 propositions, most of which were quite interesting; we believed this to be indicative of the political and social engagement of Quebecois and Canadian artists. In the end, we didn't limit our choice to six or seven propositions, but selected almost twice as many. ${ }^{10}$ The invited artists accepted to produce their works on a voluntary basis. In return we promised to actively seek funding and include them on equal footing in the collective.

Of course, the exhibition production had its ups and downs. The transparency that we all insisted on at each administrative and exhibitionary step was finally rewarded. The premise, according to which the persons present at the meetings had a decisional right that could not be questioned by those who were absent greatly facilitated the advancement of the project. The curatorial team made up of Mélanie Boucher, Nathalie Casemajor, AndréLouis Paré and Bernard Schütze also contributed to the implementation of a coherent vision and an efficient sharing of tasks. 
The time frame between the reception of a Canada Council for the Arts grant at the end of June and the opening of the exhibition at the end of September, left us only three months to clarify the content of the works and assess the requirements for their exhibition. The grant essentially covered the production and dissemination costs of the works. The mounting of the show was carried out in six well-filled days; the reactive and proactive work was carried out under the pressure of a looming deadline. The introductory text, written in large black letters on a white wall, had a manifesto ring to it. The collective and the aims of the exhibition were described as follows: A Canadian Memorial to the Victims of Communism is slated to be built in Ottawa, on a site adjacent to the Supreme Court. At the root of this exhibition is the ruling government's decision to back this private commemorative initiative and to ensure its visibility through extraordinary political and financial support. The exhibition brings together works that challenge the ideological instrumentalization of the concept of liberty, which underpins this questionable support by the Canadian government. The works focus on, among other things, the ideological capture of the principle of liberty, the significance and range of commemorative action, the opposition between capitalism and communism, prison systems, as well as the rights and freedoms and memory of minorities. In its own way each work makes up a critical, formal and conceptual response to the Canadian Memorial to the Victims of Communism. They are here exhibited in the gallery rooms, as well as in passageways and outdoor.

The works were created by artists from various generations and communities. These for the most part never-before-shown works were selected by the Entrepreneurs du commun following a call for proposals. This call invited artists from the visual arts to submit propositions for counter-monuments in tribute to the victims of liberty. By way of their subject matter, form, implementation site, the evoked experience as well as their meaning, these counter-monuments deploy strategies that are the reverse of those used by conventional monuments.

The idea of counter-monumentality was incorporated into the project prior to the exhibition and presented in the Entrepreneurs du commun's public communications: a roundtable discussion organized by the magazine 
ESPACE art actuel. Pratiques et perspectives (on November 25, 2014), a Talk Show put together by SBC Gallery (on February 28, 2015, as part of the Montréal Nuit blanche) as well as the Art et politique event held by Arts Cultures Théories Expérimentations and the Laboratoire Art et Politique (March 23, 2015, at the Cinémathèque québécoise). Moreover, an issue of ESPACE magazine called "Monuments and Counter-monuments" (Winter 2016) was piloted by three of the magazine's editorial committee members, who also happened to be part of the collective. This issue was published in the wake of the exhibition.

According to aesthetic theory, a monument is a sculpture or a work of architecture that has the function of conserving the memory of someone or something. This perennial construction, made up of durable materials, serves to recall and maintain collective memory. It must be located in a busy public space and have a direct link to the object of commemoration (including the site and the community). The monument has commemorative and historical value and, with time, it acquires a longevity value (the older it is, the more important it becomes), as Aloïs Riegl wrote in his epistemological study The Modern Cult of the Monument, published in 1903. For its part, the counter-monument questions the values upheld by the monument. It questions its place in public space, its ideological use as well as the histories it obscures through the consecration of a history that is frozen in bronze or stone as James E. Young first demonstrated. Taking on a reactive and critical stance, the counter-monument rejects and renegotiates the reasons behind the commemoration. It opens multiple perspectives on the subjects under consideration. It also revisits monumental forms and questions its materials (noble, durable), volumes (elevated, imposing), location sites (strategic, meticulously laid-out). The attempt to have the Memorial to the Victims of Communism constructed on a site adjacent to the Supreme Court of Canada blatantly exemplifies the relationship between ideology and the inherent value of a site. On the contrary, a counter-monument that has a low degree of visibility will make use of empty spaces and counter-forms and it will trigger participation rather than imposing respect. In short, it wrong foots the monumental effect. 
The artists of the Monuments to the Victims of Liberty project presented counter-monuments. Their works conveyed critical responses to the Memorial to the Victims of Communism, and several made use of the formal strategies of counter-monumentality. Spread throughout the three rooms of AXENÉO7, the public spaces of Filature (which houses the artist-run centre) as well as outdoor, the exhibition was developed with the aim of stimulating open and rich dialogue between the works and the surroundings.

The first room displayed performative and participative works that drew on the official design and model. The group EVA presented miniature models that were negative moulds of the officially proposed monument. The concept behind the project was to produce miniatures_bearing the names of people who were wrongfully put to death by authorities in democratic countrieswhich would nestle into one another so they seem to "disappear." These "souvenirs" were to be offered for sale by the collective at a stand near the Memorial. Facing this project, laid out in a line pattern, Edith Brunette's work revealed the power of a stealth intervention: sowing seeds from all around the world in the impeccable grass surface of the memorial's site to prevent the grass blades from all being identical. The subtly disruptive effect of this intervention project was amplified through its mounting in the space (rhythmically spaced with shelves, frames and live plants). Between these two works, in the middle of the room there was a blueprint for a protest monument devised by Emmanuel Galland. The proposal was made up of the letters N.O.N., which can be carried from one site to another to respond to eventual protest events. The work by Anne-Marie Trépanier and Alexandre Piral was shown in public space and paralleled by a Web presence. Set up on three sites, their monument, which was yet to be "written," invited Internet users to contribute to the creation of a polyphonous story.

The neighbouring room gathered works by Frank Shebageget, Michel de Broin, Nicolas Rivard and Steve Giasson. In this dimly lit room with a predominance of black and white tones, the idea of rebellion was more forceful than in the other parts of the exhibition. Shebageget shone a light on the eradicated history of Inuit and Metis peoples by way of a tar paper bearing the names of the 719 communities in Canada that are in a process 
of reclaiming their language, culture and territory. On an oversized pedestal, De Broin displayed a knot of destruction made of a hand clutching guns. His sculpture depicted a massacre capable of destroying everything, including oneself. For his part, Nicolas Rivard set out to methodically list each of the Canadian government's actions linked to the emergence of the Memorial to the Victims of Communism. His research-creation work made it possible to put words and images on the ignominious gestures of those in power that feel free to denounce others. Finally, Steve Giasson, focused on the appropriation of communism by capitalism (even though the latter defines itself as the opposite of the former) by associating ideas, images and objects that are in principle diametrically opposed. Moreover, the artist superimposed images of the glass coffin from Disney's masterpiece Snow White and the Seven Dwarfs with pictures of an embalmed Lenin in his glass case. He also presented copies of The Communist Manifesto by Karl Marx and Friedrich Engels that he purchased online from the multinational Walmart corporation.

The third room, across from the other two, brought together works that deal with imprisonment. Sheena Hoszko created a 1:1 scale reproduction of a segregation unit typically found in Canadian prisons. This very tight space raised the question of torture pertaining to its use. Strangely, the piece also recalled a work of minimalist art. Next to this work one could see a video that tells an epic tale of popular culture in which Thierry Marceau embodies John Wayne Gacy, a serial killer who made paintings of a questionable quality while he was waiting for his execution. These paintings sold for exorbitant prices.

Six works by Clément de Gaulejac lined the walls of the hall leading to the three exhibition spaces. De Gaulejac, whose works are guided by a critique of current events, such as with the posters he made during the 2012 Quebec student strike, created four posters with Stephen Harper as the butt of the joke. His miniature Statue of Liberty, in the shape of a musical box, played the Internationale when cranked. De Gaulejac used satirical means to make a link between the gallery works and monuments shown in public places. In the middle of the Filature space a man, presumably dead, 
was lying on the floor. Next to his body of plaster there was a sleeping bag with graphics about poverty. Near this installation by Dominique Sirois one could hear the work by Étienne Tremblay-Tardif. A succession of voices disclosed the inside dealings behind the Memorial to the Victims of Communism; in the bathrooms, words whispered softly behind closed doors to a group of... insiders. Outside, on one of the back walls, Milutin Gubash installed a commemorative plaque to pay homage to an absent monument. The plaque is still there. 
Clément de Gaulejac

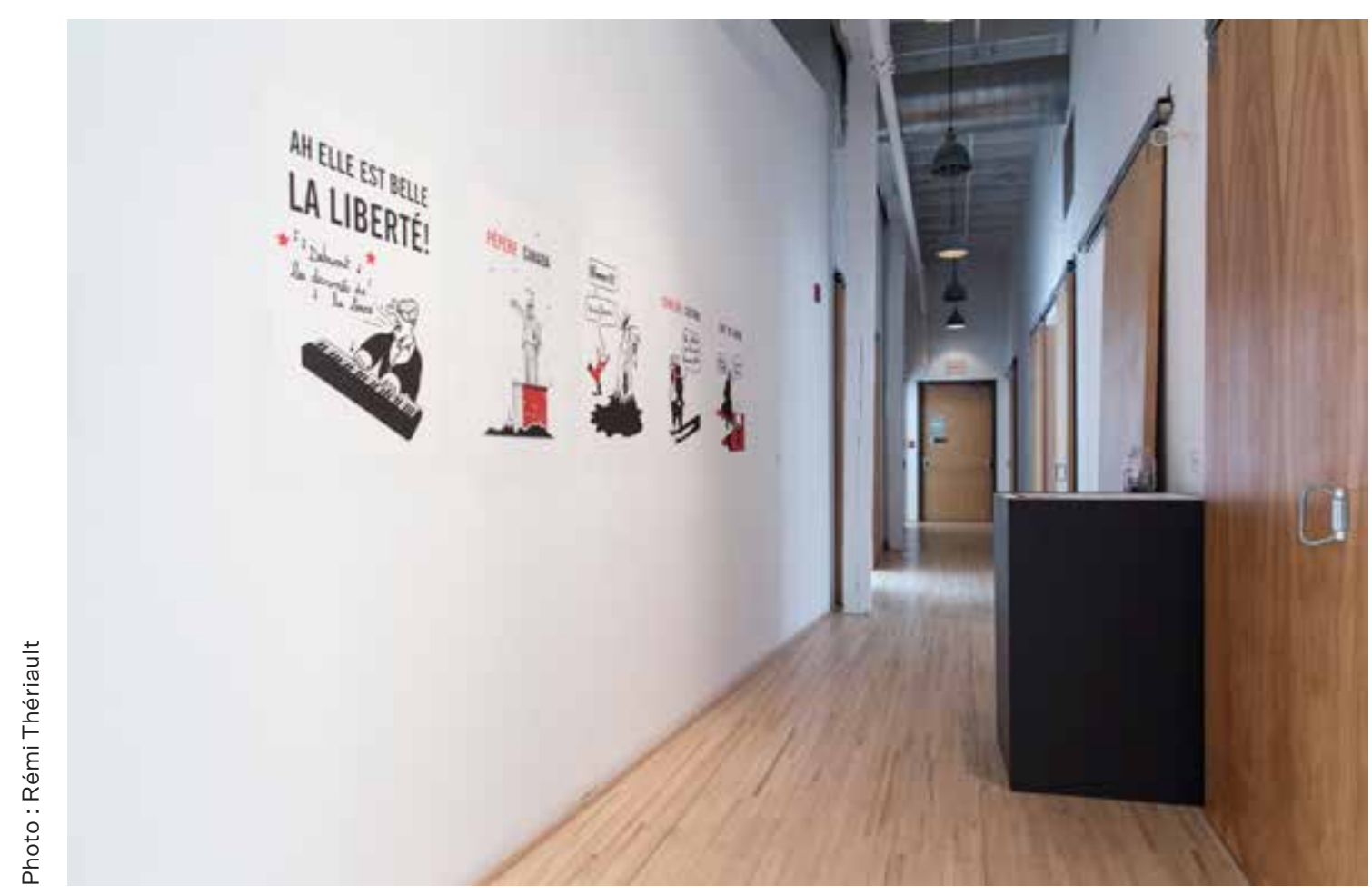




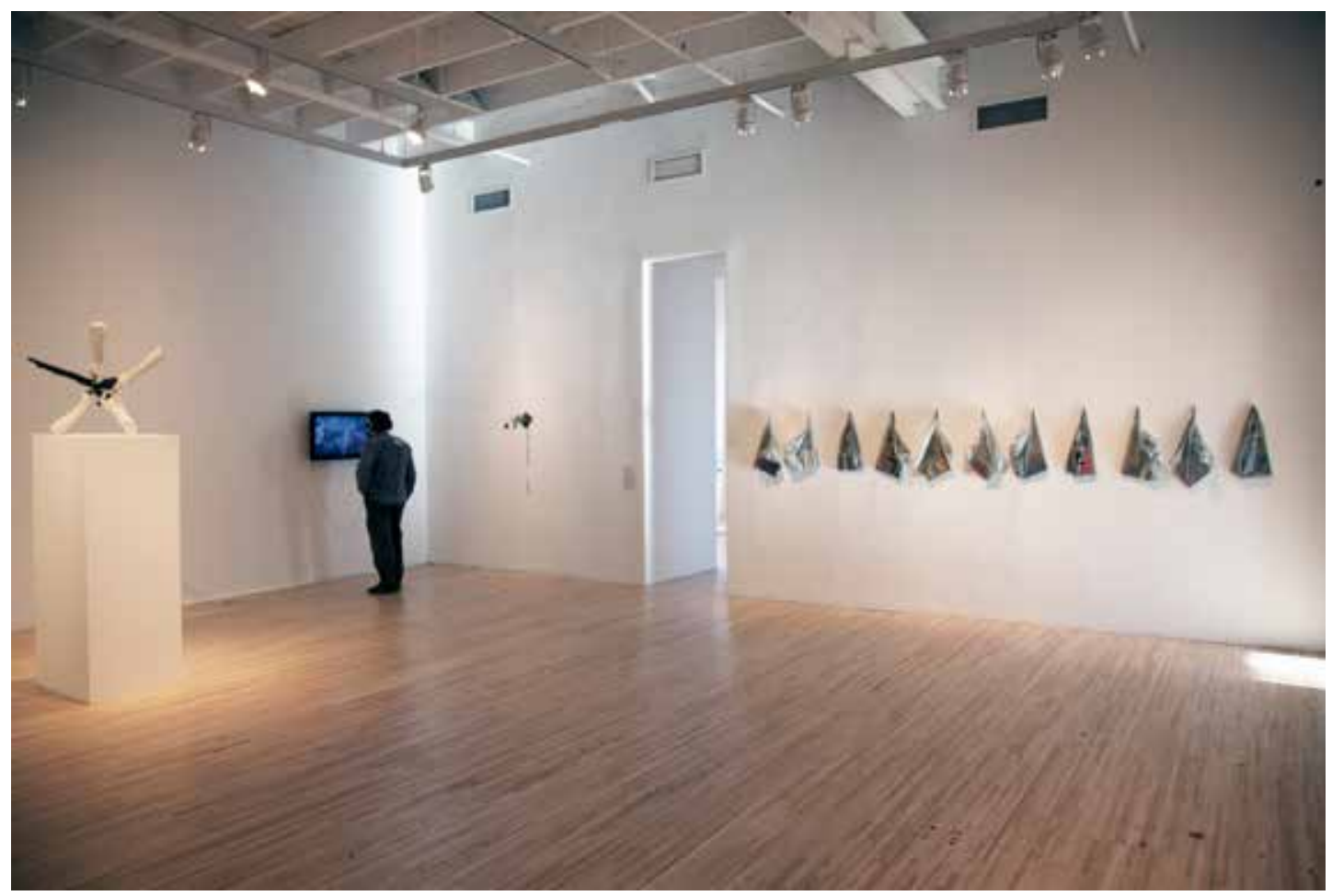




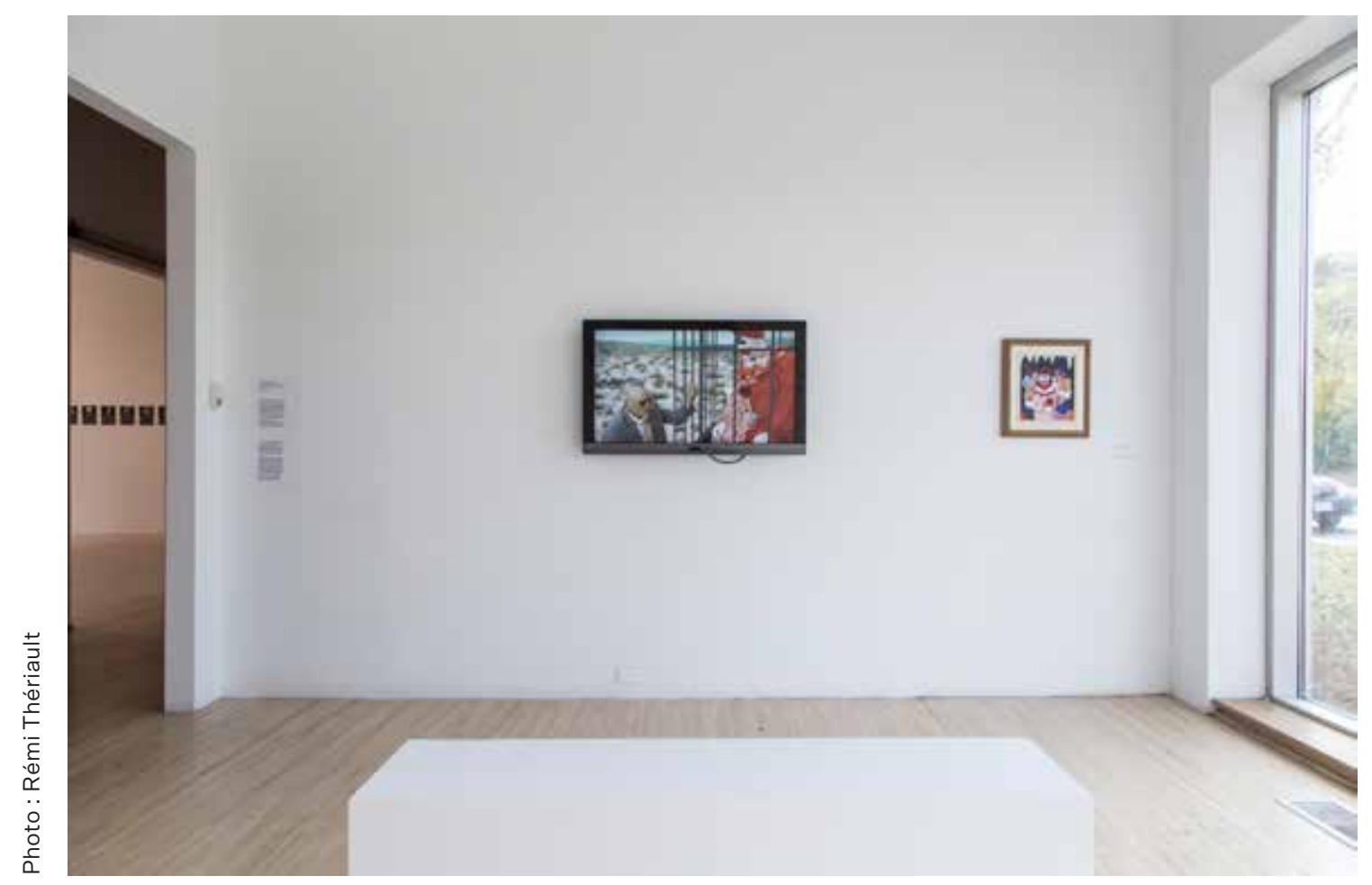




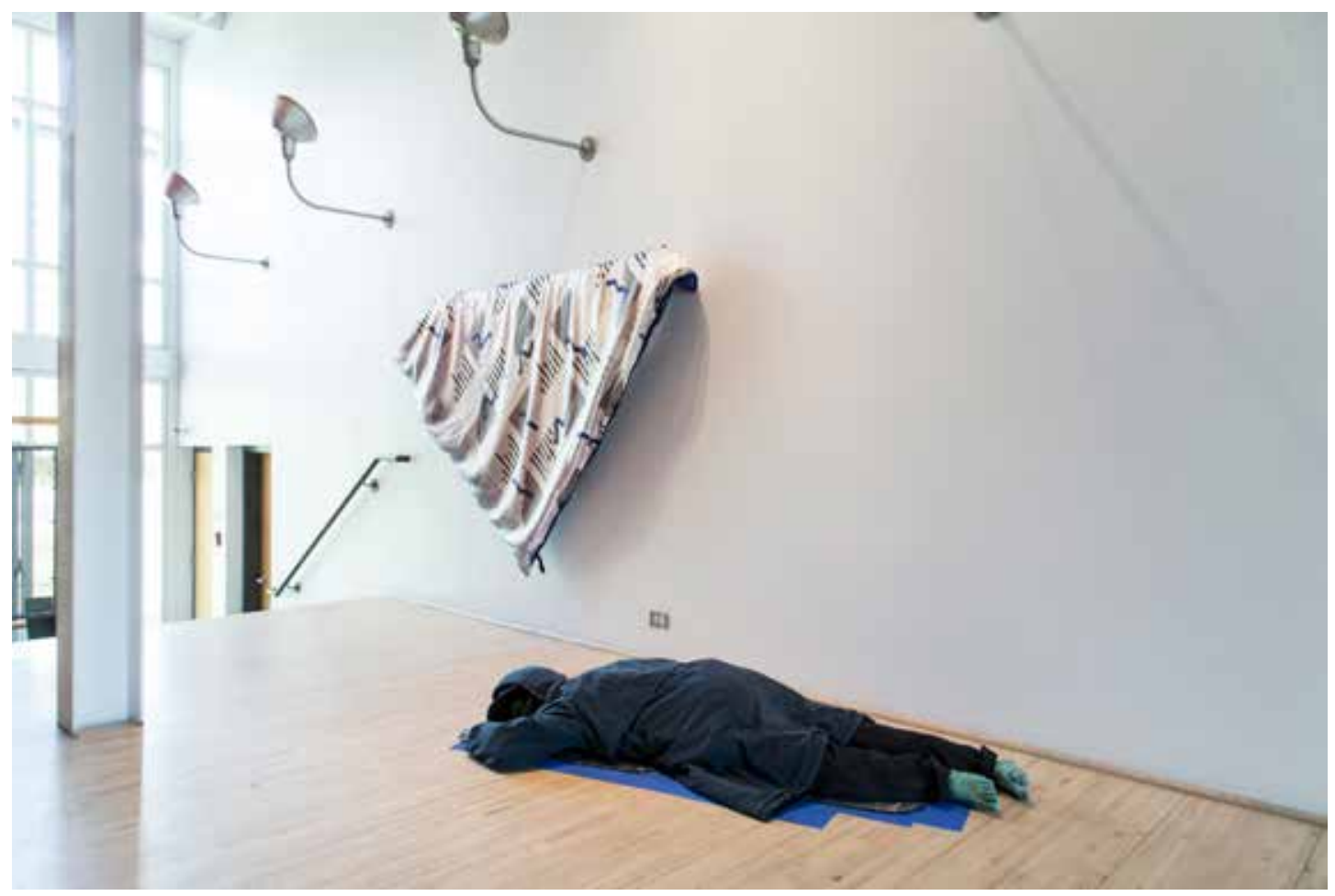


Projet EVA (Étienne Grenier et Simon Laroche)

Micro-monuments souvenirs

(Bientôt en vente!)

Archives de production, 2015

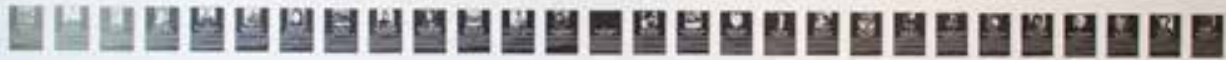

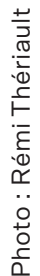

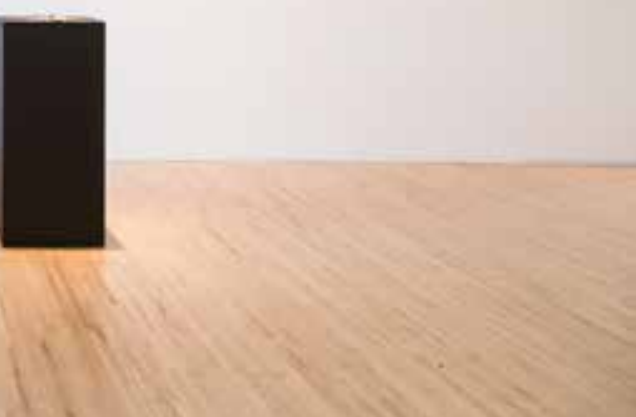




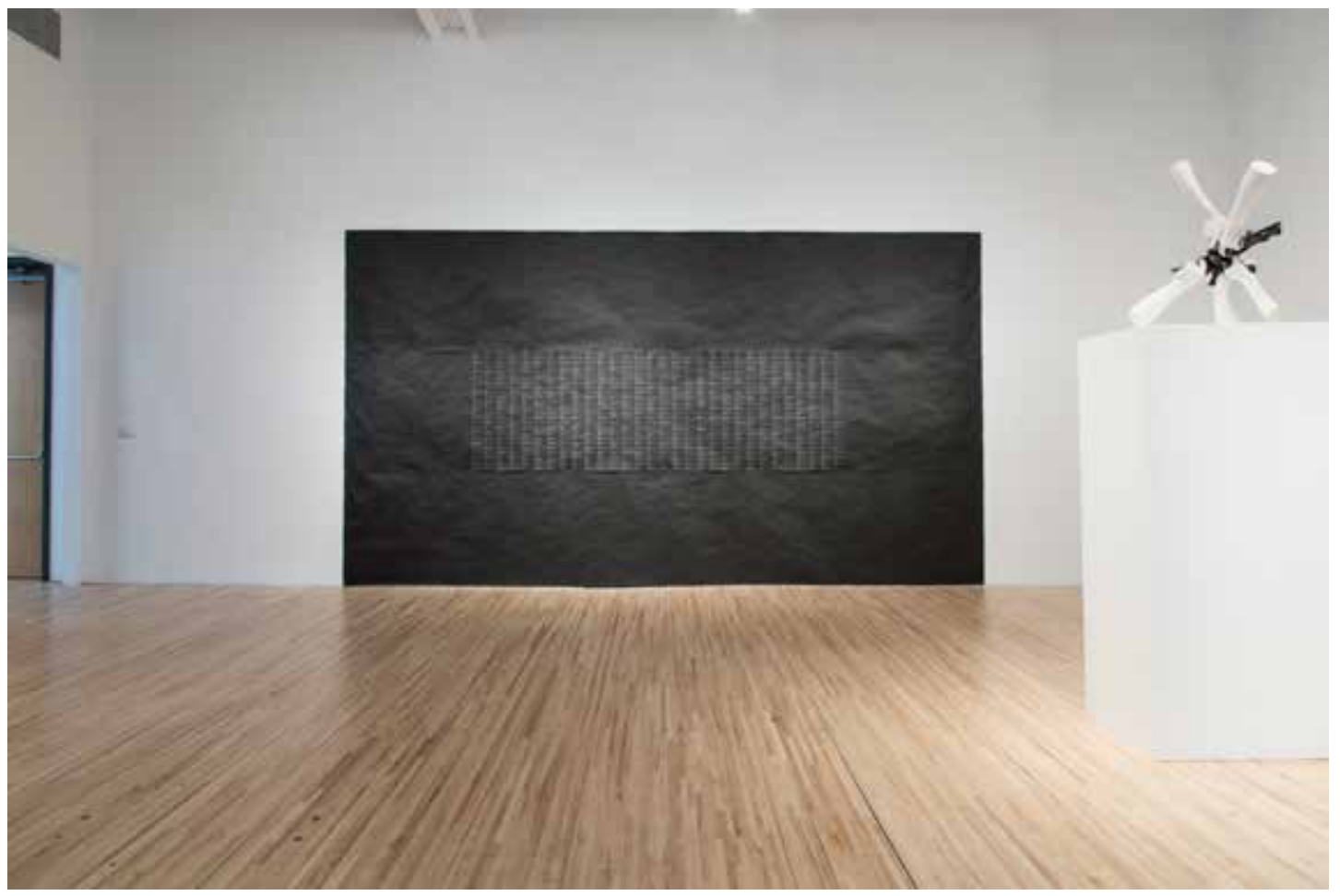

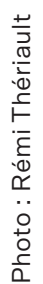


S'endormir près

\section{du monument}




\section{S'endormir près}

du monument pendant

la révolution

Exposition présentée

à la Galerie UQO

\section{Artistes}

(Gatineau, Québec)

Bojan Fajfrić

du 30 septembre

Milutin Gubash

Guillermo Trejo

Commissaire

Marie-Hélène Leblanc 
"La politique ne peut pas, si son ambition est universelle, se contenter de concentrer les intérêts des victimes. Elle doit affirmer, à l'intérieur de cette défense des intérêts des victimes, qu'il y a le mouvement d'ensemble de l'émancipation de l'humanité tout entière. C'est là qu'intervient l'idée du communisme ${ }^{11}$.»

"Ceux qui nous disent de bien regarder la représentation des abominations de notre siècle et de bien méditer leurs causes profondes pour éviter leur retour oublient une chose : les temps de l'histoire/mémoire ne sont pas ceux de l'histoire/vérité. D'où l'étrange renversement qui, à notre époque, assimile de plus en plus le mémorial au temple vide de ce qui doit rester sans représentation ${ }^{12}$. $"$

Conçue à partir d'œuvres de Bojan Fajfrić, de Milutin Gubash et de Guillermo Trejo, l'exposition S'endormir près du monument pendant la révolution propose un regard à la fois historique, politique et subjectif reposant sur une approche commissariale narrative. L'exposition induit une forme de récit qui oscille entre l'histoire et l'actualité, où l'idée du communisme devient le point de convergence. L'histoire se déploie dans chacune des œuvres des trois artistes : le récit d'une journée cruciale dans l'histoire de l'ex-Yougoslavie, le témoignage d'une carrière artistique monumentalisée et l'évocation d'une possible révolution matérialisée par l'art imprimé et des objets de protestation. La trame narrative ainsi générée propose une relecture historique et suggère une nouvelle temporalité ancrée dans le présent. Cette exposition s'inscrit en réaction à un fait d'actualité où le pouvoir étatique cherche à rendre hommage aux victimes du communisme dans une capitale nationale. Une démarche non consensuelle, mais bien réelle.

La narration dans cette exposition participe à l'écriture d'un nouveau récit aux propensions nostalgiques. Elle est construite à partir d'œuvres qui entretiennent un rapport dialogique. Cette histoire créée à partir de trois pièces permet une relecture de l'idéologie communiste en révélant, à l'aide de différents dispositifs, certains éléments déterminants de la mise en œuvre de cette idéologie, dont la reconstitution historique, le monument et la révolution. 
S'endormir La huitième session du Comité central de la Ligue communiste de Serbie s'est tenue les 23 et 24 septembre 1987. Aux yeux des historiens, l'événement représente un tournant symbolique qui a provoqué la montée du nationalisme et les guerres dans l'ancienne Yougoslavie. L'événement devait entrainer une «révolution anti-bureaucratique » destinée à rediriger la colère des masses populaires vers la transformation du système communiste à un parti unique. Mais il a surtout brutalement accru les inégalités sociales et causé des conflits ethniques. Le film Theta Rhythm, de Bojan Fajfrić, prend pour sujet le père de l'artiste, en 1987, alors qu'il tombe endormi durant l'une des plus importantes sessions politiques qui va porter Slobodan Milosevic au pouvoir. Theta Rhythm est une reconstitution détaillée de ce moment et de la routine quotidienne du père de l'artiste à l'époque. Fajfrić lui-même interprète le rôle de son père dans ce film mettant en scène cette journée cruciale de l'histoire de la Yougoslavie.

Près du monument Plutôt que de présenter un inventaire ou une liste de sa production artistique et de ses outils d'atelier (comme ce fut le cas dans sa rétrospective informelle In Union, à la Fonderie Darling en 2013), Milutin Gubash a cherché dans le cadre de cette exposition à mettre en place une sorte de casse-tête dans l'espace, ou peut-être un genre de "monument " - un endroit où l'on peut flâner et contempler ce que nous attendons de l'art-résultant de l'accumulation du matériel se trouvant sans son studio et des objets résiduels de ses expositions, ainsi que des caisses et des œuvres qu'il a utilisées, créées et exposées jusqu'ici. L'artiste propose ainsi un espace forgé à partir des objets et des éléments qui constituent les œuvres d'art. Cette accumulation d'œuvres disponibles lui permet de créer un théâtre d'idées à exprimer, une scène laissant le spectateur intervenir en partie dans sa production. C'est l'exposition d'une exposition où les œuvres d'art remettent en question les pratiques d'exposition et où la forme devient le contenu.

Pendant la révolution De son propre aveu, Guillermo Trejo s'est toujours intéressé à la relation entre la presse écrite et les événements politiques. Il utilise les éléments visuels pour explorer des enjeux sociaux. Sa pratique artistique fait appel à un processus poétique, une manière critique 
d'entamer des discussions et de partager des réflexions sur notre réalité et notre époque. Dans son travail, il aborde l'usage et l'histoire de la presse écrite. Ce qui l'intéresse, c'est le lien direct qui existe entre les processus d'impression et notre perception de la politique et des enjeux sociaux, ainsi que le rapprochement entre l'imprimé et les concepts de « révolution » et de «protestation ». Selon lui, la qualité fragile et éphémère du papier combinée au contenu révolutionnaire et militaire du texte ou de l'image constitue une analogie de la lutte politique.

L'histoire racontée-le parcours C'est dans un espace clos délimité par un mur au milieu de la salle d'exposition que débute le récit.

Les murs sont peints en gris, le plancher est recouvert d'un tapis, un projecteur fait face à un des murs et un banc occupe le centre de la pièce. C'est dans cet espace plongé dans la pénombre que le film de 16 minutes 50 secondes de Bojan Fajfrić est présenté en boucle. Les protagonistes parlent serbo-croate, le sous-titrage est en français. L'artiste, qui tient le rôle principal, incarne son propre père et participe à la reconstitution d'une journée dans la vie de ce dernier. On le suit dans ses activités banales comme se faire un café, monter à cheval au lever du jour et préparer une réunion avec sa secrétaire. Mais le moment culminant de cette journée survient pendant la huitième session du Comité central de la Ligue communiste de Serbie, alors que le père de Fajfric s'endort. Cet acte anodin de s'endormir constitue une métaphore de l'incapacité de cette génération à surmonter les circonstances de l'époque et d'affecter le cours de l'histoire.

Au sortir de la salle de projection, sur la droite, se dresse un monument C'est la pratique artistique des dernières années de Milutin Gubash qui est ici monumentalisée. La structure se compose de caissons d'emballage massifs contenant des œuvres, de documents d'archives personnelles de l'artiste, de photographies grand format face contre mur, d'une bannière déroulée sommairement au sol, de sculptures à l'effigie de l'artiste encore emballées dans du papier bulle, de drapeaux agités par un ventilateur, de matériel de production, d'éclairage de studio, du portrait de Tito; tout est là, bien que partiellement visible. À l'instar du monument, l'imposante construction sculpturale est destinée à rappeler le souvenir de quelqu'un 
ou de quelque chose. Dans ce cas-ci, elle commémore un parcours artistique. On y voit comment une chose exposée devient l'œuvre et comment les œuvres individuelles perdent leur signification singulière au profit d'une autre œuvre. Les objets constituant cette dernière attestent de l'existence d'une pratique artistique soutenue et reconnue. Monumentalisés, ces objets regroupés inscrivent Milutin Gubash et ses œuvres dans la postérité.

Devant ce monument se trouvent les restes d'une révolution Guillermo Trejo a tendu une bannière entre deux tiges de bois, comme celles dont on se sert pour faire connaître ses revendications lors de manifestations. Or le message qui y est inscrit en blanc sur noir est : INDIFFERENCE. Devant cette bannière figure un socle blanc surmonté d'un buste recouvert d'un sac à ordure noir attaché avec du ruban adhésif. Une couronne de fleurs accrochée sur le socle se fane au fil des jours de l'exposition. Si l'on tente de recomposer l'événement, il y a le reliquat d'une manifestation, le buste d'une personne inconnue, une couronne funéraire qui s'étiole et une certaine indifférence circonstancielle. Au sol, à quelques pas de là, se trouve peutêtre une forme de réponse à l'événement. À la fois objets de propagande, art imprimé et discours de l'artiste, trois affiches en plusieurs exemplaires ajoutent une clarification textuelle au contexte installatif adjacent : A POLITICAL ACTION; APOLITICAL ACTION; A POETICAL ACTION. Guillermo Trejo réussit avec finesse à brouiller la démarcation entre la politique et la poésie dans un discours subtil sur une révolution qui n’a probablement pas eu lieu.

Fin 
Translated from French

To Fall Asleep Close to the Monument 
To Fall Asleep Close to the Monument During the Revolution

An exhibition presented at Galerie UQO

\section{Artists}

(Gatineau, Quebec)

Bojan Fajfrić

Milutin Gubash

Curator

to October 31, 2015.

Guillermo Trejo

Marie-Hélène Leblanc 
"Politics can not, if its ambition is to be universal, make do with concentrating on the interests of victims. It must affirm, from within this defence of the victims' interest the collective movement of humanity's emancipation as a whole. This is where the idea of communism comes in." 11

"Those who tell us to take a good look at the representation of the abominations of our century and to ponder on their deep causes so as to prevent their return forget one thing: the times of history/memory are not those of history/truth. Whence the strange reversal that, in our era, increasingly assimilates the memorial of the empty temple with the one that must remain without representation." 12

Made up of works by Bojan Fajfrić, Milutin Gubash and Guillermo Trejo the exhibition S'endormir près du monument pendant la révolution proposes a simultaneously historical, political and subjective perspective based on a narrative curatorial approach. The exhibition suggests a narrative form that fluctuates between history and current events, in which the idea of communism serves as the point of convergence. The history here unfolds in each of the three artists' works: the story of a crucial day in the history of the former Yugoslavia, the testimony of monumentalized artistic career and the story of the possibility of a revolution materialized via protest objects and print art. The narrative line generated by this proposes an historical rereading and suggests a temporality anchored in the present. This exhibition is part of a reaction to a current event whereby state power is seeking to pay tribute to the victims of communism in a non-consensual, but very real, manner.

The narration in this exhibition contributes to the writing of a new story with nostalgic proclivities. It is built on the basis of works that enter into a dialogic relation. This three-part story opens the way for a rereading of communist ideology by deploying several setups-historical reenactment, the monument and revolution-to reveal some determining elements in the implementation of this ideology.

To Fall Asleep The eighth session of the Central Committee of the Communist League of Serbia was held between September 23 and 24, 1987. Historians view this event as representing a symbolic turn that triggered the rise of nationalism and the wars in the former Yugoslavia. The event was to 
lead to an "anti-bureaucratic revolution" intended to redirect the anger of the popular masses towards the one party communist system. However, it mostly contributed to brutally aggravating social inequalities and caused ethnic conflicts. The film Theta Rhythm, by Bojan Fajfrić, focuses on the artist's father in 1987, while he fell asleep during one of the country's most important political sessions, one which was to bring Slobodan Milosevic to power. Theta Rhythm is a detailed reenactment of this moment of the father's daily routine at the time. Fajfric himself plays the role of the father on this crucial day in the history of Yugoslavia.

Close to the Monument Rather than presenting an inventory or a list of his artistic production and studio tools (as was the case in the informal retrospective In Union, at the Fonderie Darling in 2013), Milutin Gubash here wanted to set up a kind of puzzle in space, or maybe a kind of "monument"-a space where one can stroll and contemplate what we expect of art-a result of the accumulated material that was in his studio and residual objects from his exhibitions, as well as crates and works that he used, created and exhibited up until now. The artist thus proposed a space that is crafted from both these objects and the elements constituting the artworks. This accumulation of available works enabled him to create a theatre of ideas to be expressed in a scene that allows the viewer to partially intervene in his production. It's the exhibition of an exhibition in which the artworks call exhibition practices into question and form becomes the content.

During the Revolution By his own admission, Guillermo Trejo has always been interested in the relationship between print media and political events. He uses visual elements to explore social issues. His art practice draws on a poetic process, a critical manner of starting discussions and a sharing of reflections on the reality of our times. In his work, he focuses on the use and history of print media. He is particularly interested in the direct link between printing processes and our perception of politics and social issues, as well as the correspondences between print and concepts of "revolution" and "protesting." According to him, the combination of the ephemeral and fragile quality of paper with the revolutionary and military content of the text or the image constitutes an analogy of political struggle. 
Telling the Story-the Itinerary It is in an enclosed space delimited by a wall in the middle of the exhibition room that the story begins.

The walls are painted in grey and a carpet covers the floor, a projector faces one of the walls and a bench is placed at the centre of the room. It is in this shadowy space that the 16 minutes and 40 seconds film is shown in a loop. The protagonists speak Serbo-Croatian and the subtitles are in French. The artist, who plays the main role, embodies his father as he re-enacts a day in the man's life. We follow him in everyday activities, such as making coffee, horseback riding at sunrise and preparing a meeting with his secretary. But the culminating moment of this day occurs during the eighth session of the Central Committee of the Communist League of Serbia, when Fajfrić's father falls asleep. This banal act of falling asleep becomes a metaphor of this generation's incapacity to overcome the circumstances and to modify the course of history.

At the exit of the projection room, on the right, a monument stands What is monumentalized here is Milutin Gubash's art practice over the last few years. The structure is made up of massive packing crates containing works, personal archive documents of the artist, large-scale photographs facing the wall, a banner haphazardly unfurled on the floor, sculptures bearing the artist's effigy, still packed in bubble paper, flags flapped about by a fan, production material, studio lighting, a portrait of Tito; everything is in place, though only partially visible. Like a monument, the imposing sculptural construction is intended to recall the memory of someone or something. In this case, it commemorates an artistic path. Here one sees how an exhibited thing becomes a work and how the individual works lose their singular meaning in favour of another work. The objects comprising the former are testimonies of a sustained and recognized art practice. Thus monumentalized, these assembled objects inscribe Milutin Gubash and his works in posterity.

In front of this monument one encounters the remains of a revolution

Guillermo Trejo stretched a banner between two wooden sticks, like the protest signs used during a demonstration. The message that is inscribed here in white on is: INDIFFERENCE. Before this banner there is a white 
pedestal covered with a black garbage bag that is attached with tape. A flower wreath is hung on the pedestal where it is left to wilt over the course of the exhibition. An attempt to recompose the event would wield the following: there is the remainder of a demonstration, a bust of an unknown person, a wilting funeral wreath and a certain circumstantial indifference. On the floor, just some steps away, there is a clue about the event's nature. Simultaneously propaganda objects, print art and an artist discourse, several copies of three posters add textual clarification to the adjacent installation context: A POLITICAL ACTION; APOLITICAL ACTION; A POETICAL ACTION. Guillermo Trejo deftly succeeds in blurring the boundaries between politics and poetry in a subtle discourse about a revolution that probably did not take place.

The End 


$$
\begin{aligned}
& \text { Bojan } \\
& \text { Fajfrić }
\end{aligned}
$$


Bojan Fajfrić

Theta Rhythm, 2010

Film HD, Couleur, Audio,

17 minutes, en serbo-

croate avec sous-titres
Bojan Fajfrić

Theta Rhythm, 2010

Film HD, Colour, Audio,

17 minutes, in Serbo-

Croatian with subtitles

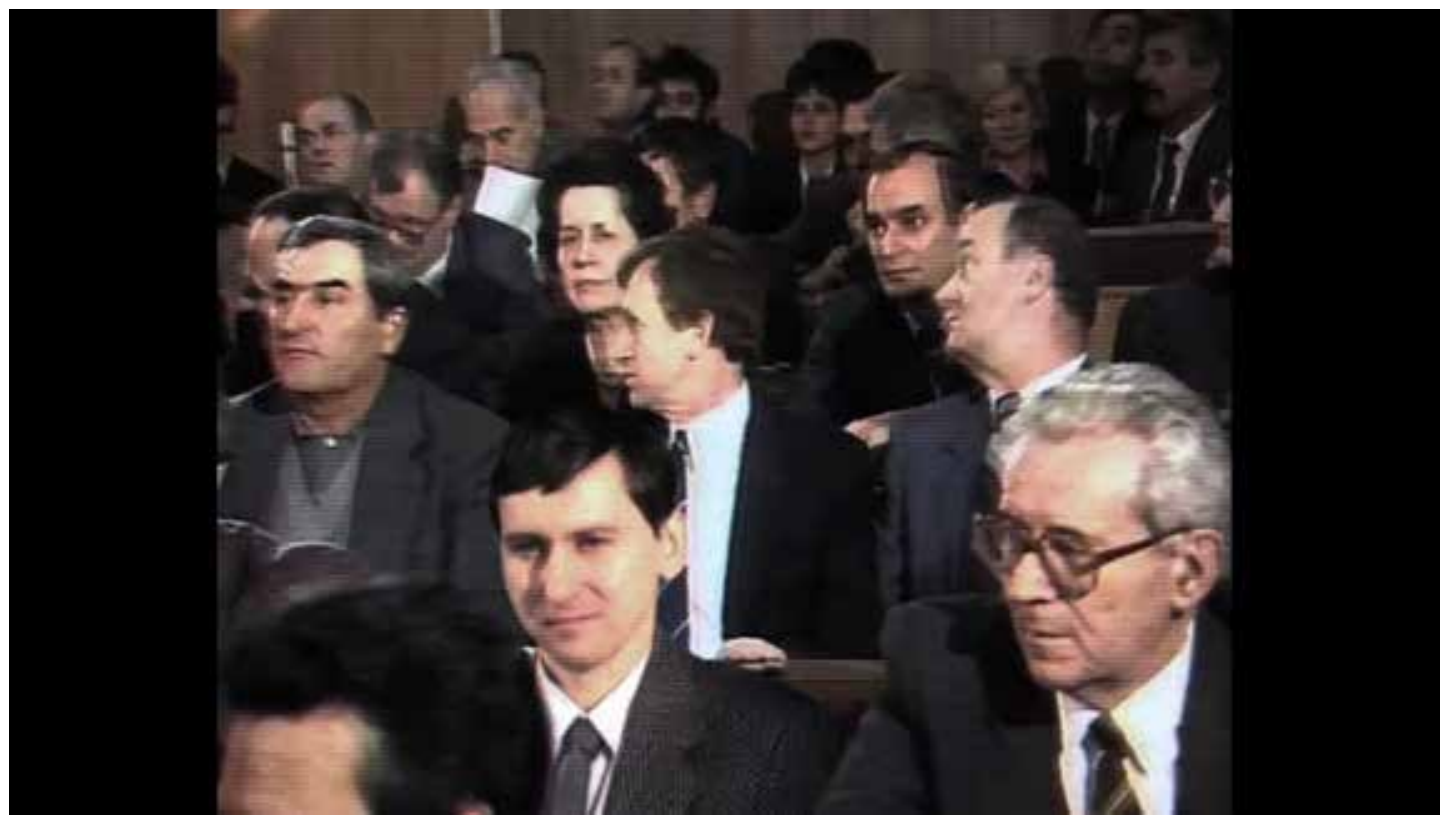




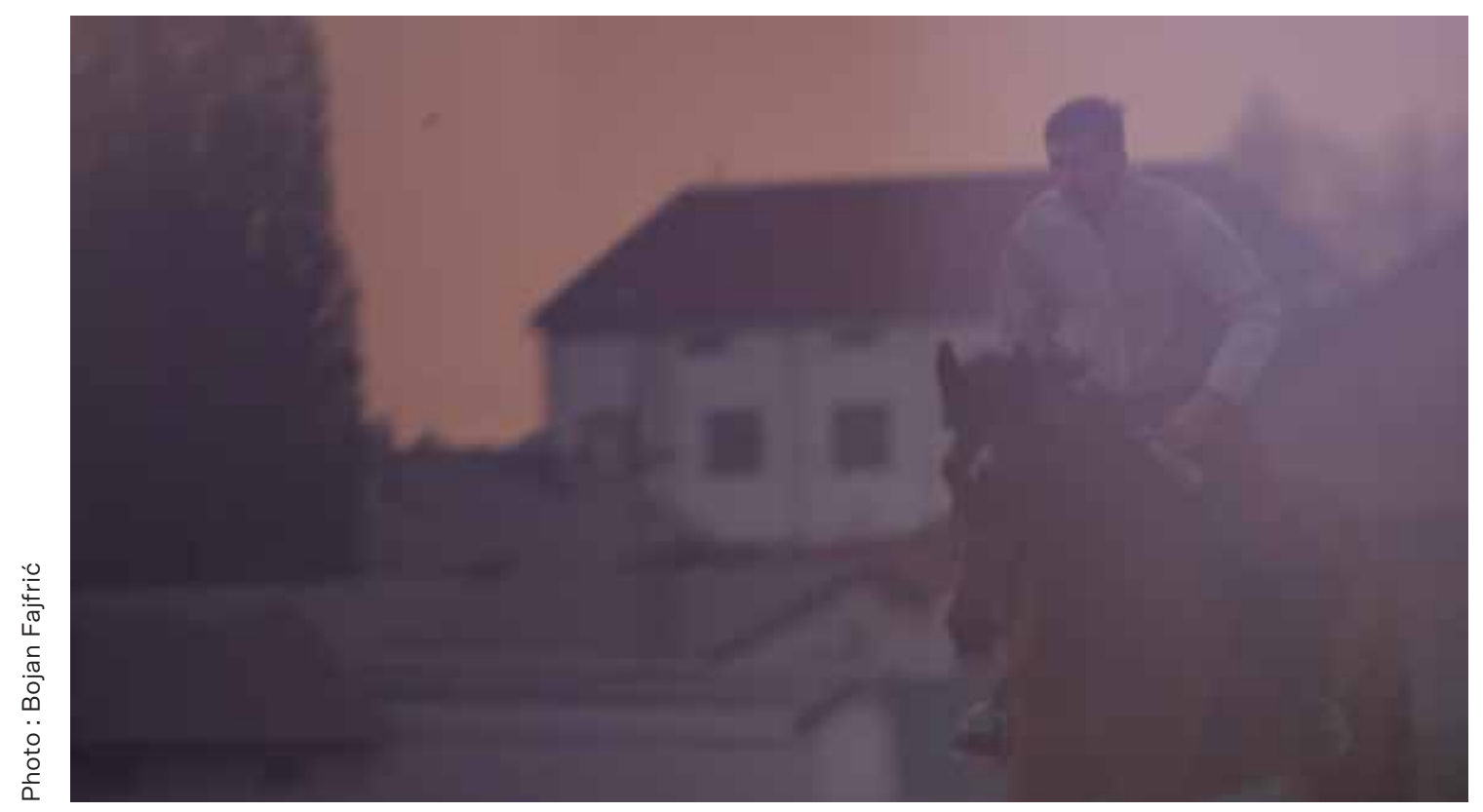



Milutin

Gubash 


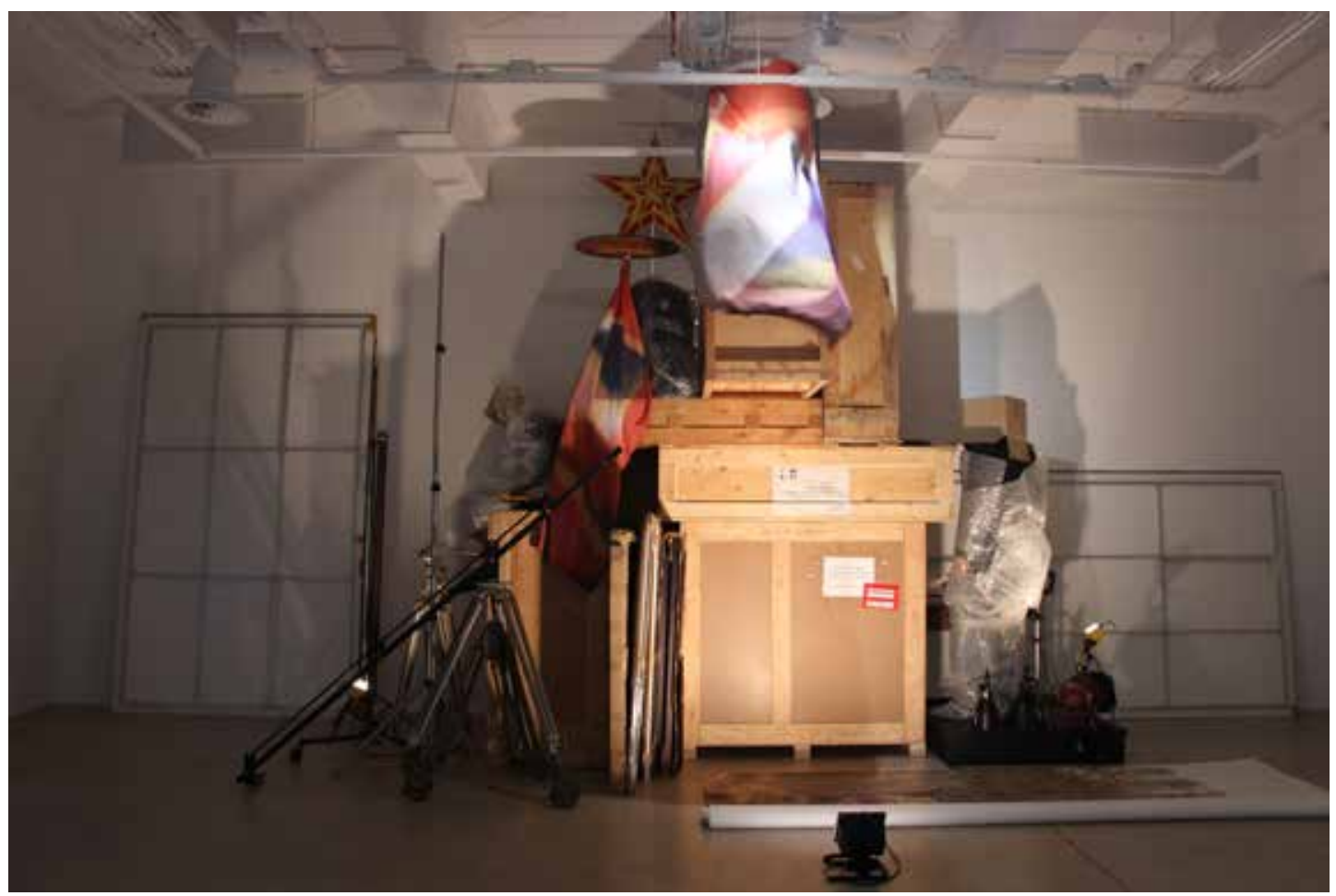




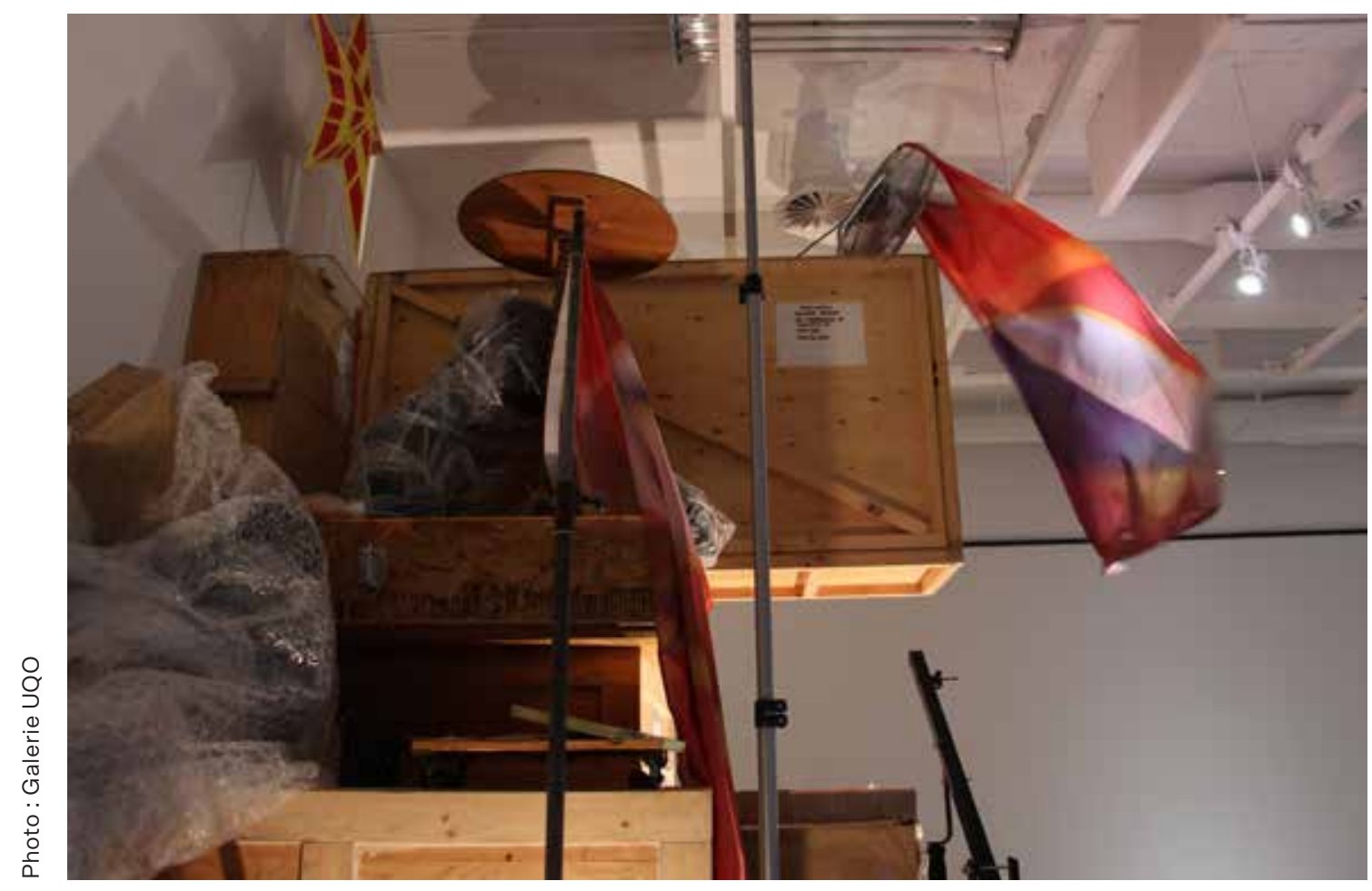



Guillermo

Trejo 
Guillermo Trejo,

installation et affiches, 2015
Guillermo Trejo,

installation and posters, 2015

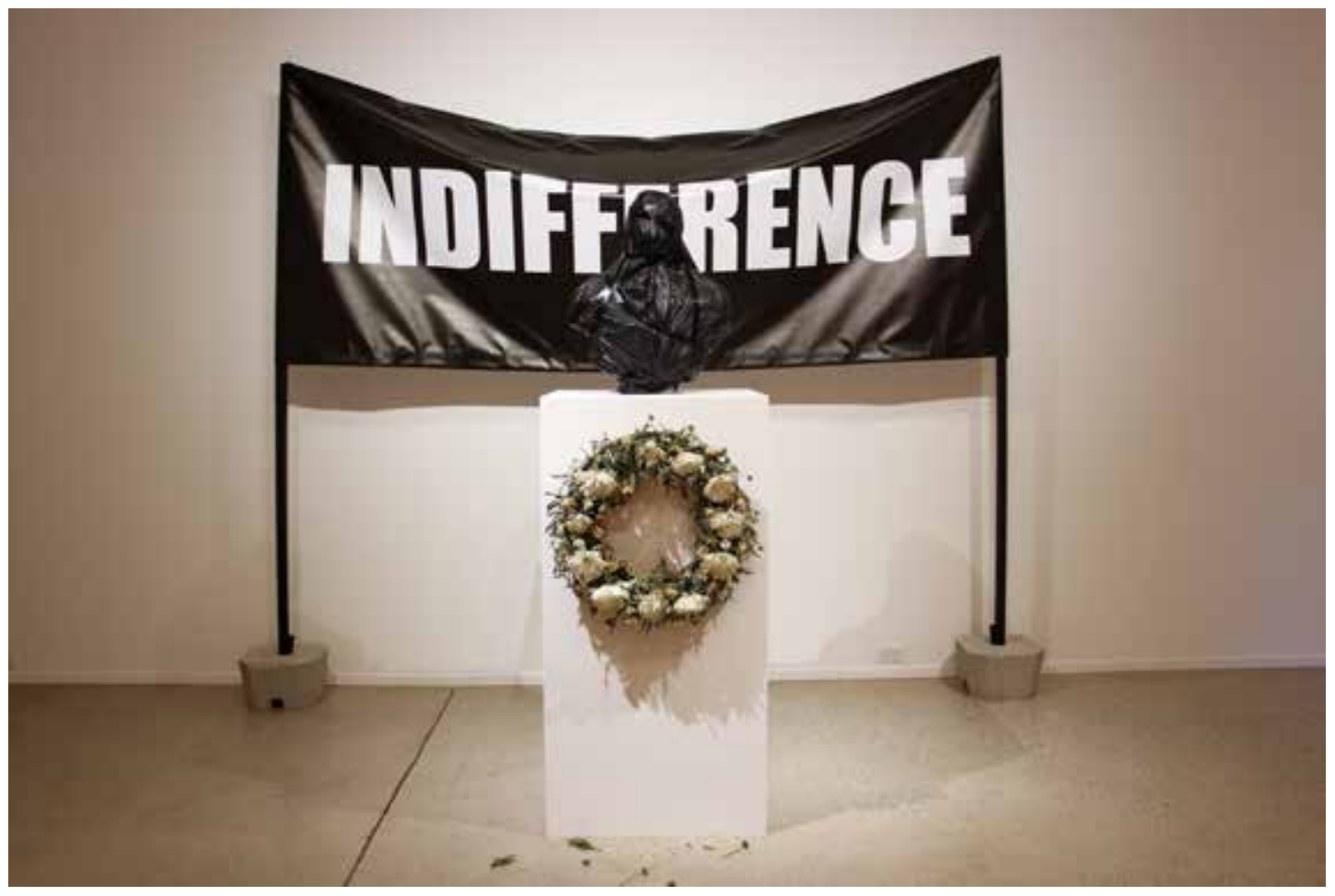

0
0
0
0
$\frac{0}{2}$
$\frac{1}{0}$
$\frac{0}{0}$
0
$\cdots$
0
$\frac{1}{0}$
$\frac{1}{0}$ 


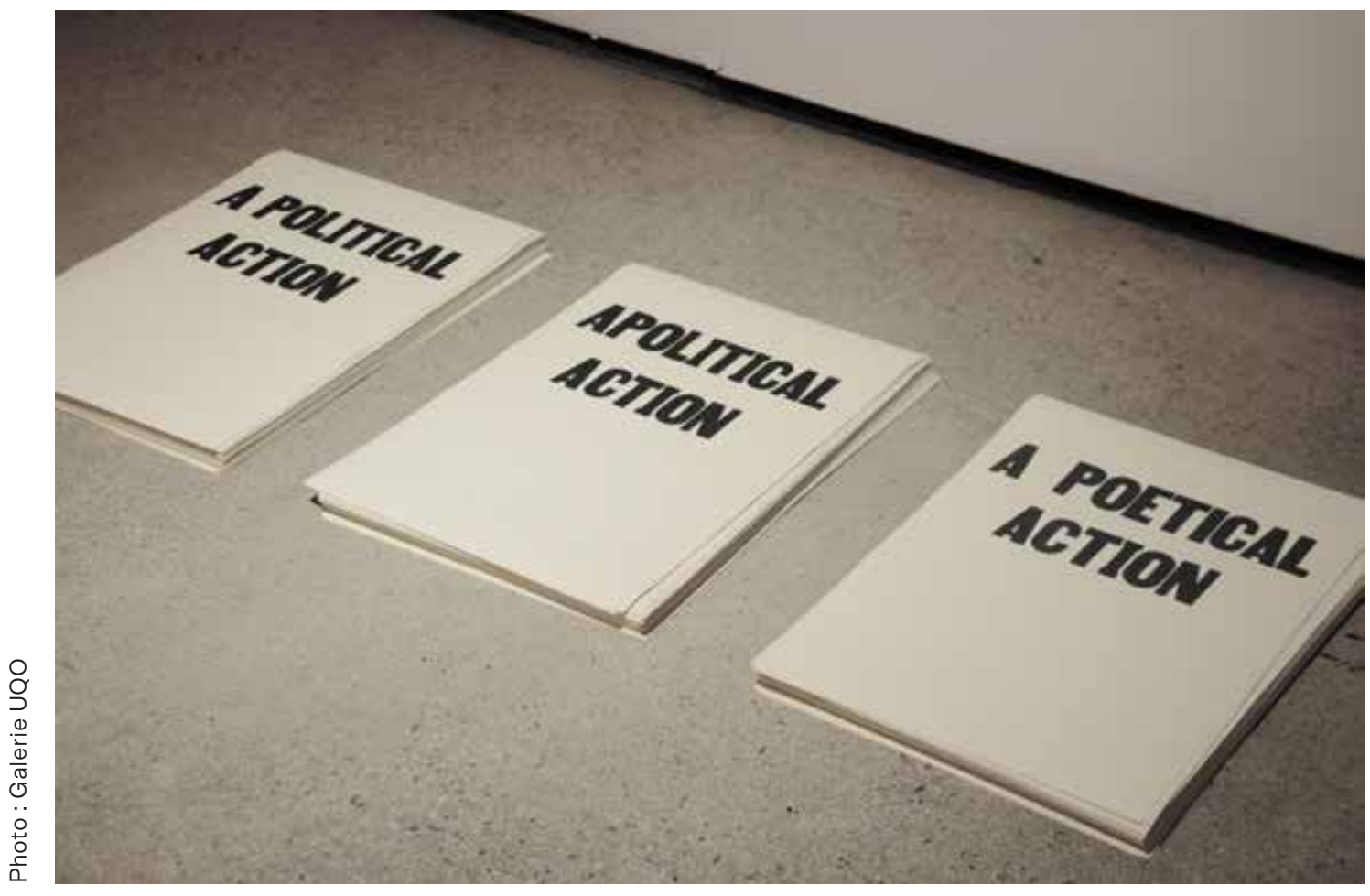



Perspectives sur le commun, la contre-monumentalité et la décolonisation de la liberté 
Regard rétrospectif sur le colloque «Perspectives sur le commun, la contremonumentalité et la décolonisation de la liberté ", organisé par le collectif Entrepreneurs du commun dans le cadre du projet Monuments aux victimes de la liberté 
Prenant à contre-pied l'opposition piégée entre communisme et capitalisme, Entrepreneurs du commun a voulu rendre hommage aux victimes de la liberté tout en contribuant à une pensée du commun. Le colloque s'inscrivait dans cette perspective. Il avait pour objectif premier de remettre en question l'instrumentalisation idéologique du concept de liberté en le resituant dans le contexte du néolibéralisme, de l'impérialisme occidental et de l'histoire coloniale du Canada. «Nazisme, marxisme-léninisme, aujourd'hui, terrorisme - ils ont tous un point commun : la destruction, la fin de la liberté humaine ", affirmait l'ancien premier ministre Stephen Harper lors d'un dîner organisé par Hommage à la liberté. L'obsession sécuritaire qui préside à cette condensation bancale fonctionne comme une sorte de mantra conjuratoire qui discrédite d'entrée de jeu l'exploration d'autres voies politiques à la fois progressistes et radicales.

Face à tant de confusion historique et de grossières simplifications idéologiques, nous avons cherché à ouvrir un espace de réflexion soutenu et convivial afin de discuter des nombreux enjeux soulevés par la controverse entourant la construction du monument. La journée s'est articulée autour de trois axes : Le commun et la transindividualité; Monumentalité postcommuniste; Décoloniser la liberté (canadienne). Par le croisement de différentes approches conceptuelles, esthétiques et politiques, nous avons voulu susciter une réflexion collective renouvelée sur la portée des actes commémoratifs et sur leur rôle dans l'imaginaire contemporain du commun ${ }^{13}$. Dans une perspective libérale, c'est bien connu, la liberté des uns s'arrête là où commence celle des autres. Cette définition classique de la liberté implique un État souverain qui se porte garant du respect des prérogatives des uns et des autres. Loin d'être «naturel », ce régime s'intensifie autour des figures de l'homo œconomicus et de l'entrepreneur de soi. Michel Foucault a écrit des pages importantes sur le (néo)libéralisme comme régime de gouvernementalité qui se propose de "produire de la liberté à chaque instant » et qui, comme l'a bien montré Nicolas Rivard dans son projet La fatigue culturelle, se révèle être un régime d'épuisement généralisé des ressources (humaines et non-humaines). La critique de ce rapport d'implication mutuelle entre liberté individuelle propriétaire et souveraineté extractiviste a traversé 
le colloque de multiples façons. Chacun à leur manière, Érik Bordeleau et Frédéric Neyrat ont ouvert des pistes vers une pensée du commun à la fois micropolitique et planétaire, invitant à des formes de conspiration et d'entre-prises transindividuelles où, pour reprendre l'heureuse formule de Bakounine, «la liberté des autres étend la mienne à l'infini ». Les travaux de contextualisation historique menés par Yevgeniy Fiks et Maria Silina sur l'héritage de la Guerre froide ont permis de problématiser plus finement notre situation de vainqueurs autoproclamés de ce conflit. La table était ainsi mise pour formuler une critique décoloniale de cette performance monumentalement mortifère qu'on appelle «Canada ». Au fil des récits de Stacey Douglas et Darren O'Toole, c'est le désir même de monumentalité étatique qui s'est peu à peu effrité face à la puissance joyeuse et destituante des usages autochtones de la nature et du territoire. "La nature fait ses propres monuments " : avant de penser couvrir de béton anti-communiste un parc de la colline parlementaire, peut-être pourrions-nous apprendre à nous mettre à l'écoute du vivant et simplement, anti-monumentalement, dépolluer la rivière des Outaouais, tel que l'a réclamé une chef algonquine lors de son passage à une commission de la capitale nationale ${ }^{14}$.

Avec le recul, trois ans après la réalisation des interventions à caractère politique d'Entrepreneurs du commun, dont le colloque constituait le volet réflexif, il est frappant de constater à quel point la question de la commémoration historique et de sa concrétisation dans les monuments publics a refait surface-particulièrement aux États-Unis - avec une force qui était difficilement envisageable il y a quelques années. Au lendemain de l'écrasante défaite du gouvernement Harper en octobre 2015, l'érection du controversé Monument aux victimes du communisme a été mise de côté par la nouvelle ministre du Patrimoine au profit d'un projet nettement moins ambitieux et controversé intitulé l'Arc du souvenir, dont les travaux devraient s'achever en 2018 sur un site moins sensible que la place entre la Cour suprême et la Bibliothèque nationale du Canada proposée initialement par le gouvernement Harper ${ }^{15}$. Par la suite, la polémique s'est calmée ici au Canada avec l'élection du gouvernement libéral de Trudeau, moins enclin à la régression. Toutefois, une contestation plus générale concernant les 
monuments publics et le modelage institutionnel de la commémoration historique a pris de l'ampleur dans les débats actuels et les événements inquiétants qui sont survenus dans le sillage de l'élection de Trump aux États-Unis et l'affirmation de la droite alternative américaine.

Ceci n'était d'ailleurs que trop évident lors de la tragédie de Charlottesville déclenchée par les positions diamétralement opposées de la population au sujet de la proposition de retirer la statue de Robert $\mathrm{E}$. Lee ${ }^{16}$. Bien que ce débat concerne plus précisément la résurgence de tensions historiques non résolues aux États-Unis, il soulève également la question plus vaste de savoir comment le passé historique peut encore perturber le présent par la visibilité que lui confèrent les monuments publics. Dans cette perspective, le colloque organisé par Entrepreneurs du commun (et ses traces documentaires) - précurseur a posteriori et par pur hasard-a constitué une tribune tout indiquée à partir de laquelle engager une réflexion critique plus large sur ces problèmes actuels encore plus pressants. D'ailleurs, outre le contexte situationnel et engagé du colloque, les idées et les questions soulevées au cours de cette journée de présentations et de discussions ont ouvert la voie à des pistes théoriques et permis d'établir des outils conceptuels utiles pour mieux comprendre notre conjoncture particulière et son intrication dans un monde que nous n'avons pas créé, mais que l'on peut contribuer, un tant soit peu, à changer. 

A look back at the "Perspectives on the Commons, Counter-Monumentality and the Decolonization of Liberty" symposium, organized by the Entrepreneurs du commun collective as part of the Monuments to the Victims of Liberty project 
To counter the loaded opposition between communism and capitalism, Entrepreneurs du commun sought to pay tribute to the victims of liberty all the while contributing to rethinking the idea of the commons. The symposium was thought out with this in mind. Its primary goal was to question the ideological exploitation of liberty by resituating it in the context of neoliberalism, Western imperialism and Canadian colonial history. "Nazism, Marxist-Leninism, today, terrorism-they all have one thing in common: the destruction, the end of human liberty," Prime Minister Stephen Harper stated during a Tribute to Liberty dinner evening. The obsession with security that underlies this unsound interpretation is like a mantra thwarting the exploration of other progressive and radical political avenues. Faced with this plethora of gross historical confusions and ideological simplifications, we proposed to open a space for in-depth and convivial reflection and to discuss the issues raised as part of the controversy surrounding the monument's construction. The symposium was structured by three blocks: 1 . The Transindividual and the Question of the Commons; 2. Post-Communist Monumentality; 3. Decolonizing (Canadian) Liberty. At the crossroads of the various conceptual, aesthetic and political approaches that were to be mobilized as part of this day, this encounter aimed to prompt and renew collective thought around the impact of commemorative actions and their relationship to contemporary conceptions of the commons. ${ }^{13}$

In a liberal perspective, it is well known, liberty stops there where the freedom of others begins. This classical definition of liberty implies a sovereign State that guarantees that the prerogatives of each and all are respected. Far from being "natural" this regime is intensified around the figure of homo œconomicus and the entrepreneur of the self. Michel Foucault wrote important passages about (neo)liberalism as a regime of governmentality that proposes to "produce liberty at every instant" and, as Nicolas Rivard has aptly shown with his project La fatigue culturelle, it proves to be a regime of a generalized exhaustion of resources (both human and non-human). The critique of this relation of mutual inclusion between individual, propertied freedom and extractivist sovereignty was variously addressed during the symposium. Each in their own way, Érik Bordeleau 
and Frédéric Neyrat, cleared paths to reflect on the commons in both a micropolitical and planetary dimension. In the process they suggested forms of transindividual conspiracies and resistant enterprises in echo of the Bakunin's felicitous expression: "My personal freedom, confirmed by the liberty of all, extends to infinity." Yevgeniy Fiks and Maria Silina's endeavours to contextualize the heritage of the Cold War made it possible to more precisely problematize our self-proclaimed situation as winners of this conflict. The stage was thus set to formulate a decolonial critique of the monumental and grim performance called "Canada." Over the course of Stacey Douglas and Darren O'Toole's presentations, it is the very desire for state-driven monumentality that was slowly eroded in the face of the joyous and destituent Indigenous uses of nature and the territory. "Nature makes its own monuments." Before imagining ways to cover a park on Parliament Hill with anti-communist cement, we should maybe heed the call of the living and simply depollute the Outaouais river, as an Algonquin chief called for during her pronouncement at a National Capital commission. ${ }^{14}$ Looking back now, three years after this successful unfolding of the Entrepreneurs du commun's politically inflected interventions, among which the conference was the reflective chapter, it is striking to what extent the issue of historical commemoration and its embodiment in public monuments has recently resurfaced with a brutal vehemence-particularly in the US - that was hardly foreseeable a few years ago. In the immediate aftermath of the Harper government's crushing defeat in October 2015, the plan for constructing the controversial Memorial to the Victims of Communism was shelved by the new Minister of Canadian Heritage and replaced by a far more modest and less controversial project, titled the Arc of Memory, that is scheduled to be completed in 2018 on a less symbolically conspicuous site then the square between the Supreme Court of Canada and National Library of Canada, initially proposed by the Harper government. ${ }^{15}$ Subsequently the controversy has waned here in Canada with the election of the less regressively inclined Liberal Trudeau government. Nevertheless, the broader contestations regarding public monuments and the institutional shaping of historical memorialization have loomed large in the current 
debates and disquieting events that have erupted in the wake of the Trump election and the emboldening of the alt-right movement.

This was of course made all too evident by the Charlottesville calamity, which was triggered by the diametrically opposed views regarding the proposed removal of the Robert E. Lee statue. ${ }^{16}$ Though this debate speaks specifically to the re-emergence of unresolved historical tensions in the US context, it also points to a broader questioning of how the historical past can still trouble the present via the visibility afforded by public monuments. In this perspective, the Entrepreneurs du commun conference and its documentary traces, prescient only in hindsight and by happenstance, provided a fitting forum from which to more broadly critically reflect on these currently even more pressing problematics. Moreover, setting aside the situated and engaged context of the conference, the ideas and questions raised during this day of presentations and ensuing discussions cleared theoretical paths and forged useful conceptual tools to get a bearing and grip on our particular conjuncture and its entanglement within the contours of a world not-of-our-making that, if so willing, we can also be a small part of making otherwise. 


\section{Programme du symposium Symposium programme}

Panel 1

La transindividualité et le commun
Frédéric Neyrat

«Prologue au communisme

planétaire»

Université du Wisconsin à Madison,

Département de littérature comparée

Érik Bordeleau

"Prises et entre-prises du commun»

SenseLab, Université Concordia

Discutante :

Émilie Bernier, Université d'Ottawa,

Département de sciences politiques
Panel 2

Post/Communist

Monumentality
Yevgeniy Fiks

«Monument to Cold War Victory "

Artiste

Maria Silina

"(Cold)War and (Anti)Communist Agenda in Canadian and Russian Contemporary Public Art » UQÀM, Département d'histoire de l'art

Discutant :

Peter Hodgins, Université Carleton, Département d'études canadiennes 
Panel 3

Decolonizing (Canadian)

Freedom-Table ronde

\section{Darren O'Toole}

Université d'Ottawa, Faculté de droit

Stacy Douglas

Université Carleton,

Département de droit et d'études

juridiques

Discutante :

Dalie Giroux, Université d’Ottawa,

Département de sciences politiques
Panel 4

Table ronde avec les artistes de l'exposition Monuments aux victimes de la liberté
Artistes conférenciers :

Nicolas Rivard, Simon Laroche, Étienne Grenier, Étienne TremblayTardif, Edith Brunette, Dominique Sirois, Michel de Broin et Steve Giasson.

Discutants :

Érik Bordeleau et Nathalie Casemajor. 

Selon une rumeur qui circule depuis longtemps à Ottawa, les murs des édifices du Parlement contiennent des ossements d'ancêtres algonquins. Et il s'avère que cela pourrait être exact : une plage de sable située près du Musée canadien de l'histoire était connue en 1843 pour être un lieu de sépulture autochtone traditionnel, et son sable a servi à fabriquer le mortier des édifices du Parlement en 1860. Autrement dit, ce symbole fondateur du Canada souverain tiendrait debout grâce à des ossements d'Autochtones pillés. Bien que ces ossements soient simplement un outil assurant l'intégrité de ces bâtiments nationaux, d'autres sont méticuleusement instrumentalisés dans la construction des mythes fondateurs de la nation. Cette croyance que le sang et les os cimentent la patrie est un important fil conducteur du nationalisme de droite au Canada anglais. Comme bien d'autres nationalismes militaristes, il soutient que la nation est sanctifiée par le sang, les os et les viscères de ceux qui ont sacrifié leur vie sur les champs de bataille. Comme l'explique Juha Siltala, cette tendance nationaliste croit que «le corps social se renouvelle périodiquement au prix des corps individuels; la nation est toujours constituée du sacrifice ultime [...]. La nation est donc littéralement faite de la chair de ses citoyens... ${ }^{17}$ ".

Au Canada, comme dans d'autres pays colonisés, la sanctification de certains corps et l'exclusion d'autres sont inextricablement liées au processus de constitution de lieux et de symboles nationaux sacrés. Comme nous le rappelle Nestor Garcia-Canclini, le sacré a « deux composantes : c'est ce qui dépasse la compréhension et l'explication de l'homme, et ce qui dépasse la possibilité de le changer ${ }^{18}$ ». L'entreprise de sacralisation de la mémoire et des lieux publics est généralement justifiée par le fait qu'elle permet de contrecarrer ce que les nationalistes qualifient de tendances individualisantes et amnésiques de la vie quotidienne. Cependant, ces projets de sacralisation sont aussi bien souvent une remise en cause implicite de la légitimité des approches de la mémoire publique fondées sur la critique, le débat, la parodie, l'expérimentation et le dialogue, qui endossent la contestabilité et la polysémie du passé collectif et qui cherchent à ébranler les dogmes.

Les monuments commémoratifs de guerre font partie du paysage culturel du centre-ville d'Ottawa depuis toujours. Ils sont emblématiques des liens 
qui unissent le Canada à la mémoire collective de l'Empire britannique, et en même temps une affirmation de son indépendance. Jusqu'à tout récemment, ces lieux soi-disant sacrés étaient couramment et aisément utilisés à des fins profanes et politiques. Par exemple, la place du Monument commémoratif de guerre du Canada a été fréquentée pendant des années par les piétons et les skateurs, ainsi que par les employés de bureau, les résidents et les touristes venant y dîner ou y flâner, tout en servant de point de ralliement aux manifestations politiques-espace public ou terrain de jeu/d'entente animé ${ }^{19}$.

Ces dernières années, toutefois, nous avons assisté à une répression de ces usages profanes et publics. En 2000, l'espace ouvert de la partie sud de la place a été empiété par l'installation de la Tombe du soldat inconnu (un autre morbide projet de mémoire qui a nécessité l'exhumation de la dépouille d'un présumé soldat canadien en France et sa réinhumation à Ottawa). Puis, en 2007, le gouvernement Harper a réagi à des photographies d'hommes urinant sur le monument en implantant un programme de sentinelles en vertu duquel deux sentinelles non armées devaient surveiller la place. Comme l'a expliqué le quotidien Ottawa Citizen, leur présence avait pour but de « renforcer le message que le site devait être traité avec dignité et non comme une aire de jeu publique ${ }^{20} »$. Par ailleurs, depuis l'assassinat tragique de l'une des sentinelles par un terroriste, celles-ci montent la garde sous la protection de policiers d'Ottawa armés de fusils d'assaut. Plus récemment, des panneaux portant la mention «Respect et Silence: nous nous souviendrons » dans les deux langues officielles ont été installés sur le site ainsi que des cordons afin d'en restreindre l'accès.

Une pléthore d'autres monuments en hommage aux anciens combattants et aux victimes de guerre canadiens occupent de grands pans de terrain sur les axes protocolaires de la ville. Toutefois, les deux plus récents projets de monuments-le Monument commémoratif aux victimes du communisme et le Monument national de l'Holocauste - sont les premiers où l'État canadien étend sa soif de corps sacrificiels au-delà de ses frontières nationales. Ce changement pourrait avoir un lien avec un épineux projet national qui visait à décrier fortement la violence étatique à l'étranger, bien qu'en maintenant 
sous silence, jusqu'à récemment, les plans de génocide de l'État canadien contre les peuples autochtones. Mais il pourrait aussi s'agir d'une tentative à peine voilée de diversifier le paysage commémoratif national en s'adressant aux communautés diasporiques dont les épreuves les ont menées au Canada. Il est difficile de discerner si ces monuments constituent un pas vers l'ouverture et l'inclusivité ou s'ils sont une forme de récupération hégémonique, mais ils font certes partie d'un assaut continu contre le public, le polysémique et le profane au nom de la sacro-sainte nation.

Le samedi 26 septembre 2015, un groupe de 40 à 50 intellectuels, activistes et membres de la communauté a organisé une visite guidée du centre-ville d'Ottawa, intitulée Déambulations profanes. Dans son acception carnavalesque, profaner consiste à «remettre en jeu », à ramener dans l'usage commun ce que le sacré rend incontestable, ce qui est interdit, placé sur un piédestal ou sous une vitrine. Comme l'explique Giorgio Agamben, la profanation "désactive les dispositifs du pouvoir et restitue à l'usage commun les espaces qu'il avait confisqués ${ }^{21}$ ". La marche s'est arrêtée devant divers monuments existants ainsi qu'à l'emplacement prévu des deux récents projets de monuments. À chaque arrêt, un ou plusieurs groupes se servaient d'un porte-voix pour effectuer une brève intervention. Tous pouvaient improviser sur ce qui avait déjà été dit. En perturbant l'habitus convenu des lieux nationaux de commémoration - l'immobilité, la soumission, le respect, le silence, la distance et une forme imposée de commémoration - par notre performance, nous avons cherché à remettre en question la sacralisation du prétendu passé canadien partagé à travers des actes de profanation.

Les interventions visaient à lever le voile sur les monuments en exposant leurs facettes plus nébuleuses ${ }^{22}$. Certaines remettaient en cause la mythologisation du passé collectif en révélant les silences d'un monument et en proposant des contre-récits, d'autres traitaient de la politique culturelle relative à la création d'un monument et du message recherché, tandis que d'autres faisaient appel à la parodie et au ridicule. Par opposition à la solennité presque religieuse des cérémonies nationales organisées autour de ces monuments et à l'univocité autoritaire des visites guidées, les Déambulations profanes visaient donc à remettre en jeu le passé commun et à ramener l'espace sacralisé à l'usage public/commun. 
CODA La déambulation profane s'est terminée dans un pub près des chutes de la Chaudière, jadis un des sites sacrés les plus importants des Algonquins, sur le territoire non cédé où se trouve aujourd'hui Ottawa-Gatineau. Lors de son intervention, Shady Hafez a parlé du projet de développement Zibi, qui consiste à transformer un site industriel construit au $19^{\mathrm{e}}$ siècle sur les îles de la Chaudière en un complexe écologique abritant des condos, des restaurants et des boutiques. Il a également parlé des tensions suscitées par ce projet au sein des communautés algonquines. Bien que la restitution du site sacré ait rapidement été écartée, la ville et les promoteurs du projet ont offert aux Algonquins un train de mesures économiques inclusives typiquement néolibérales, un accès limité au site et une reconnaissance symbolique/ornementale. Dans le sillage de ce projet de profanation corporative de l'espace autochtone, nous avons été mis au défi de réfléchir à une nouvelle approche du sacré, intimement liée à la nature, au lieu et à la mémoire sans être facilement ou aisément décrite ou déconstruite. Nous avons également été amenés à nous demander à quel moment la profanation peut aussi être une désacralisation.

Sur les berges de la rivière des Outaouais, où l'on peut entendre le bruit des chutes en arrière-plan, mais où leur vue est obstruée par les usines, les mots de George Grant résonnent : "La relation conquérante au lieu a laissé sa marque en nous. Quand nous allons dans les Rocheuses, nous avons parfois l'impression que les dieux sont présents. Si tel est le cas, ils ne peuvent pas se manifester comme étant des nôtres. Ce sont les dieux d'une autre race. Nous ne pouvons les connaître à cause de ce que nous sommes et de ce que nous avons fait. Ils ne représentent rien d'immémorial pour nous, à part l'environnement en tant qu'objet. Même nos villes ont été des campements sur la voie de la conquête économique ${ }^{23}$.» Pendant ce temps dans la Chapelle du Souvenir, pièce sacrée de l'édifice central du Parlement, le cœur éloquent du Livre renfermant les noms des soldats morts à la guerre continuait de battre, insensible à l'idée que les murs euxmêmes ne dorment pas tranquilles. 

A long-standing Ottawa rumor holds that bones of ancestors of the Algonquin peoples were embedded in the walls of the Parliament Buildings. It turns out that it might be true: a sand beach beside the Museum of History was known by 1843 to be a traditional Indigenous burial site and its sand was quarried in 1860 to make the mortar for the Parliament Buildings. In other words, perhaps the foundational symbol of the sovereign Canadian nationstate, might be literally held together by the pilfered bones of Indigenous peoples. But while these literal bones are mere instruments in binding processes that hold national architectures together, other bones are meticulously instrumentalized in the construction of national grounding myths. The faith in the nation-binding power of blood and bones is a significant thread in the right-wing strain of English-Canadian nationalism. Like many other militaristic nationalisms, it holds that the nation is sanctified by the blood, bones and viscera of those who sacrificed their lives in wars. As Juha Siltala explains, this strain of nationalism believes that the "social body is periodically renewed at the cost of individual bodies; the nation is always constituted in the last sacrifice ... Thus, the nation is literally created out of the flesh of its citizens..." 17

In Canada, like in other settler-colonial states, the sanctifying of certain bodies and the exclusion of others is inextricable from processes of constituting national sacred spaces and symbols. The sacred, Nestor Garcia-Canclini reminds us, "has two components: it is what overflows human understanding and explanation, and what exceeds the possibility of changing it." 18 The project of sacralizing public memory and space is usually justified on the ground that it counteracts what nationalists identify as the individualizing and amnesic tendencies of daily life. However, such sacralizing projects are usually also an implicit attack on the legitimacy of public memory practices based on critique, debate, parody, experimentation and dialogue, which assume the contestability, and polysemy of the collective past and which aim at unsettling dogma.

War memorials have always had a presence in the cultural landscape of downtown Ottawa; they were emblematic of Canada's connection to the collective memory of British Empire and simultaneous assertions of its 
independence. Until recently, these purportedly sacred spaces were routinely and easily repurposed to profane and political ends. For example, the National War Memorial plaza for many years has been criss-crossed by pedestrians and skateboarders, used by office workers, residents and tourists as a place to eat lunch or to hang out and as a rallying point for political demonstrations - a vibrant public space or playground/commons. ${ }^{19}$

In recent years, there has been a crackdown on these profane and public uses. In 2000, the openness of the southern part of the plaza was disturbed by the emplacement of the Tomb of the Unknown Soldier (another ghoulish memory project which required the exhumation of the remains of a presumably Canadian soldier in France and its reburial in Ottawa). Then in 2007, the Harper government responded to photographs of men urinating on the memorial, by creating a sentry program in which a pair of unarmed sentries would police the plaza. As the Ottawa Citizen explained, their presence was meant "to re-enforce the message that the site was to be treated with dignity rather than as a public playground." ${ }^{20}$ Furthermore, after one of the sentries was tragically murdered by a terrorist, the sentries began to stand guard under the protection of Ottawa police armed with assault rifles. More recently, signs saying "Lest we forget: respect and silence" in both official languages have been posted on the plaza and cordons have appeared to regulate access to the site.

A plethora of other monuments and tributes to Canadian veterans and victims of wars occupy significant real estate in the ceremonial axes of the city. However, Ottawa's two newest monuments-the Memorial to the Victims of Communism and the National Holocaust Monument-mark the first time that the Canadian state has reached beyond national borders in its hunger for sacrificial bodies. This shift might be linked to a fraught national project aimed at loudly decrying the state violence of elsewhere while, until recently, attempting to maintain a silence around the genocidal projects of the Canadian state against Indigenous peoples, but it might also be a thinly veiled attempt to pluralize the national commemorative landscape by speaking to diasporic communities whose traumas brought them to Canada. While it is hard to discern whether these monuments signify a move towards 
openness and inclusivity or whether they are hegemonic co-optations, they are part of an ongoing assault on the public, the polysemic and the profane in the name of the national sacred.

On Saturday September 26, 2015, a group of 40-50 scholars, activists and community members organized a walking tour through downtown Ottawa titled Profane Perambulations. In its carnivalesque mode, to profane is to "put back into play," to return to common use that which the sacred makes unquestionable, that which has been cordoned off, placed on a pedestal or behind glass. As Giorgio Agamben explains, profanation "deactivates the apparatuses of power and returns to common use the spaces that power had seized." ${ }^{21}$ The walk stopped at various existing monuments as well as the sites or the proposed sites of the two newest monuments. At each stop, one or more of the group would take up a bullhorn and perform a brief intervention. All members of the group were given the chance to riff on what had already been said. By disrupting the prescribed habitus of national commemorative spaces-immobility, submission, respect, silence, distance and an authoritative form of remembrance-through our performance, we tried to challenge the sacralization of the supposed shared Canadian past through acts of profanation.

The interventions were designed to shine a light on the monuments with the aim of exposing some of their shadowy animas. ${ }^{22}$ Some of the interventions challenged the mythologization of the collective past by revealing silences of the monument and advancing counter-narratives, others discussed the cultural politics of the monument's creation and intended message while others chose to parody and ridicule. As opposed to the quasi-religious solemnity of the state rituals organized around these monuments or the authoritative univocity of the organized tour, the Profane Perambulations were thus designed to put the common past back into play and to return sacralized space back to public/common use.

CODA The profane perambulation concluded at a pub near the Chaudière Falls. The Falls were one of the most important sacred sites for the Algonquin peoples on whose unceded territory Ottawa-Gatineau is built. In his intervention near Chaudière Falls, Shady Hafez spoke about the proposed 
Zibi development project which seeks to transform a $19^{\text {th }}$ century industrial site built on a series of islands surrounding the Falls into eco-friendly condos, restaurants and shops. He spoke also of the tensions that it has created within and between Algonquin communities. While the return of the sacred site was quickly taken off the table, the city and the developers offered the Algonquins a classically neoliberal and inclusive package of economic opportunities, limited site access and symbolic/ornamental recognition. In the shadow of this project of corporate profanation of Indigenous space, we were challenged to think about a very different version of the sacred that is intimately tied to nature, place and memory and not so easily or comfortably described or deconstructed. We were also challenged to wonder when profanation may also become desecration.

Standing by the banks of the Ottawa with the sound of the Falls in the background, but with our vision of them obscured by factories, the words of George Grant resonated: "The conquering relation to place has left its mark within us. When we go into the Rockies we may have the sense that the gods are there. But if so, they cannot manifest themselves to us as ours. They are the gods of another race, and we cannot know them because of what we are and what we did. There can be nothing immemorial for us except the environment as object. Even our cities have been encampments on the road to economic mastery." ${ }^{23}$ Meanwhile in the Memorial Chamber, a sacred room at the core of Parliament's Centre Block, the tell-tale heart of the book of the names of the sacred dead soldiers brought home from war continued to beat, undisturbed by the thought that the walls themselves might be unquiet. 
Instructions to the National War Memorial of Canada, Ottawa

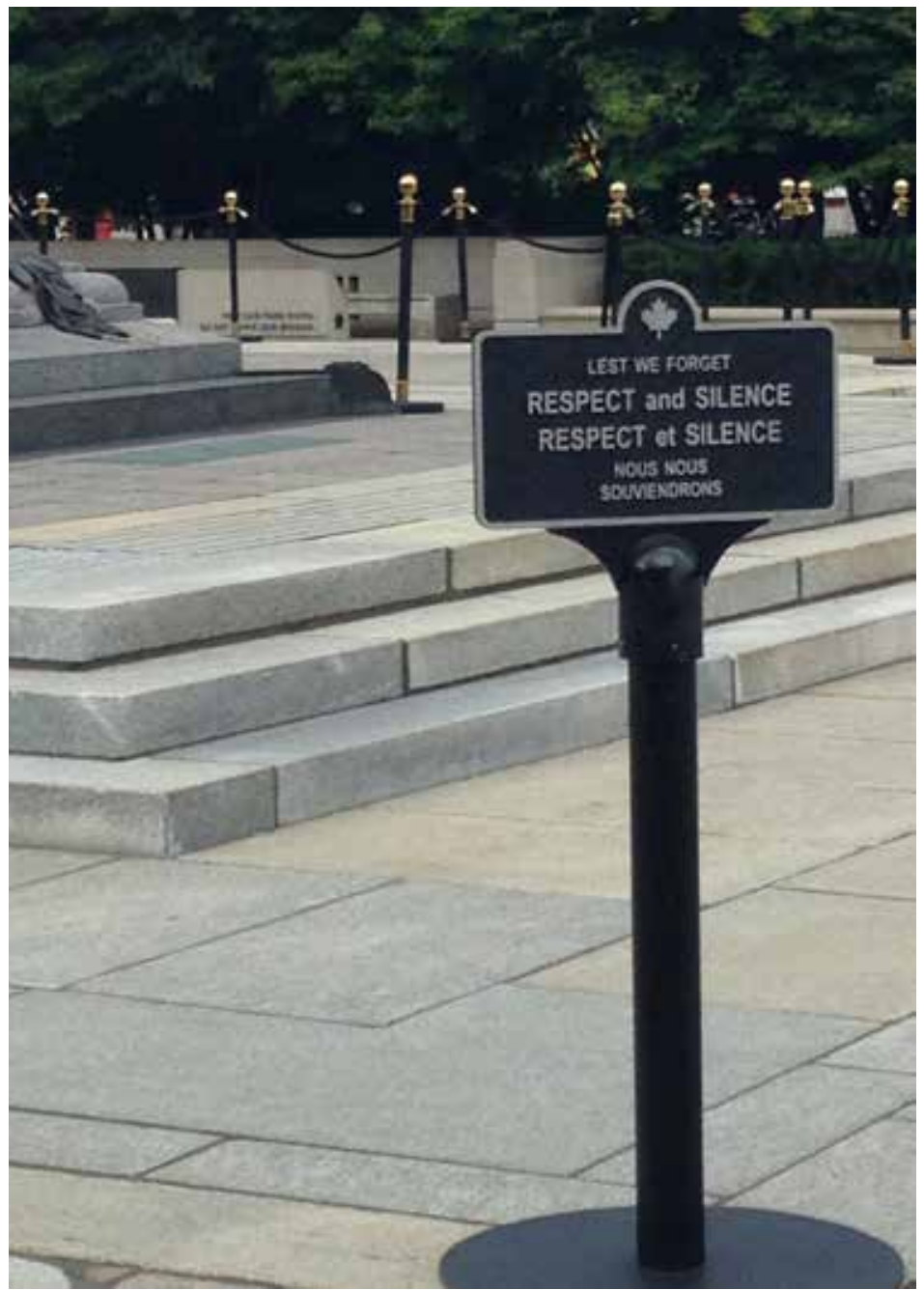

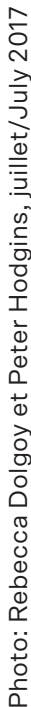




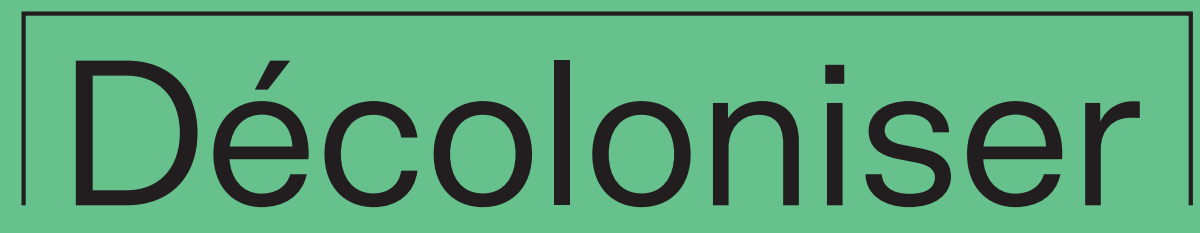

la liberté
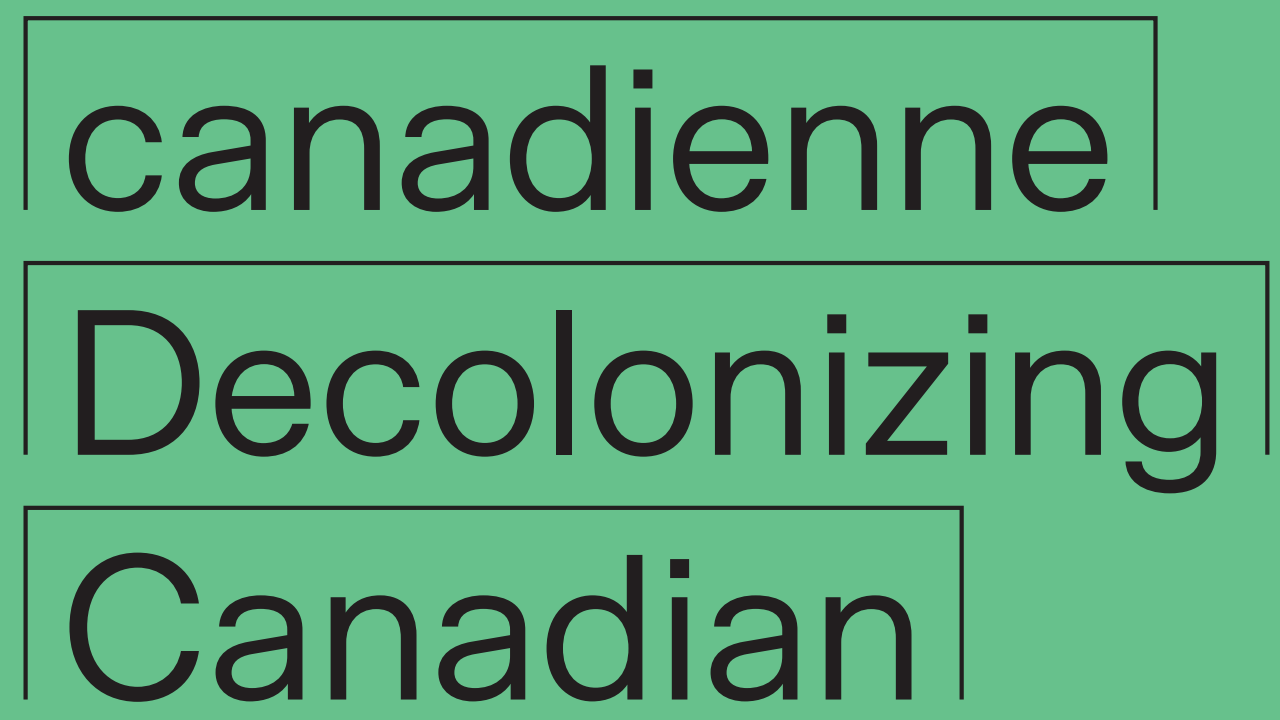

Freedom 

Les faits nous amènent à la pensée, à l'art, à l'action : on nous a proposé un monument. Un monument aux victimes de. Un moment aux victimes du communisme.

Allons déposer aux pieds d'argile d'un géant une gerbe de questions, sous la forme d'un désir de décolonisation : qu'est-ce qu'un monument? Qu'est-ce qu'une victime? Et qu'est-ce que le communisme? Enfin, qu'est-ce que tout cela fait de nous, assemblés aux abords des socles de signes?

Pratiques de possession dans la vallée de l'Outaouais D'abord, une interpellation majeure, un marqueur fort : "leurs victimes ", "ses victimes » ou les « victimes du » (communisme) - n'y a-t-il pas là une forme de prétention à la propriété? Le critique littéraire ojibwé du sud des Grands Lacs Gerald Vizenor/Gérald Vézina parlerait ici de «manifest manner», une expression de sémiologie coloniale qu'il a forgée artisanalement pour décrire les gestes revendicateurs de la colonisation. De manière appropriative. Le «communisme », dit "Canada », " a » des victimes.

Et qui donc, demandons-nous encore, est ce «communisme », propriétaire de «ses» victimes? Plus encore, qui a le pouvoir d'attribuer de tels titres de propriété? Qui pose cet acte (terroriste) d'attribution des maîtres?

"[P]endant tout le vingtième siècle, le Canada est devenu un refuge pour ceux qui fuyaient les gouvernements communistes et un nouveau chez soi pour ceux qui voulaient vivre en liberté", a déclaré le premier ministre Harper.

Ici, là-bas, à Ottawa, sur et au cœur de la scène principale du théâtre patriotique du Dominion of Canada, si loin de l'Europe et pourtant remplis d'une émotion fraternelle pour tous les morts de l'histoire humaine, nous sommes témoins et nous sommes partie prenante de la révélation du pouvoir magique d'attitrer, de désigner, d'attribuer, de qualifier. Le pouvoir de maudire, de jeter des sorts. La réalité se fabrique devant nos yeux cernés et ébahis.

"Canada », par la voix de ventriloques autorisés cachés dans l'espace cérémonial des édifices gouvernementaux perchés sur le cap le long de la rivière des Outaouais, attribue des "victimes " au "communisme ", qui devient une figure majeure de la catégorie des régimes anthropophages. Un cosmos politique est mis à l'œuvre. Rempli de dieux proches et lointains, gentils et méchants, ce cosmos est saturé de terreur, de charme, d'enchantement, 
d'anathèmes et de beauté tragique. Le clair-obscur du théâtre tératologique outaouais contribue à une aura de mystère et de vérité-le monstre est capturé, mis en cage, offert au peuple, "stupéfait mais content ", comme a dit Machiavel à propos des spectateurs des crimes de César Borgia.

Mais pourquoi diable "Canada» tient-il à nous parler de communisme? Attitrer, impliquer, qualifier, juger, cela suppose toujours de se déplacer dans l'espace à grande vitesse, d'aménager, de fabriquer un lieu-dans un geste preste et mystérieux, en portant robes et perruques et en brandissant sceptres et couronnes. Dans l'attribution des victimes au communisme, dans ce «manifest manner», le «communisme » est un monstre politique qui partage le corps de ses victimes avec «Canada», sorte de derviche boréal halluciné. II y a un festin politique dans la clairière, à la rencontre des deux rivières-les pères mangent les enfants qu'ils se sont rêvés en leur racontant des histoires.

Dans le théâtre politique, les corps (victimes, victuailles) sont toujours fabriqués sous la forme de cette externalité dont la souveraineté se nourrit. Les victimes du communisme ainsi capturées comme des castors deviennent une monnaie d'échange qui apporte une légitimité au Canada, havre de liberté- les corps sont la seule nourriture des États.

Les charmes de la Couronne Les victimes de la tyrannie, tels que sont présentés les "réfugiés des régimes communistes» dans la rhétorique du Monument aux victimes du communisme, sont comme des champions des vertus capitalistes, au même titre que les colons lockéens, qui veulent bien s'identifier comme "Canadiens». Ensemble ils forment un groupe de poupées poudrées et immobiles au milieu du showcase national, avec de petits papiers dans leurs mains. Leur mise en scène est dédiée à la justification infinie et indéfinie du processus de dépossession qui s'appelle «souveraineté canadienne ». La Couronne est un monument vivant - un art performatif ancien.

Dans cet ordre poétique, la souveraineté, le Canadian freedom, équivaut à la prérogative de la gestion du sacrifice humain. Le pouvoir d'attribuer des victimes à... Tuer pour vivre-comme l'a exprimé Gertrude Stein en évoquant ce que l'esprit américain sait et qu'il doit oublier pour être capable de dormir. 
Tuer pour vivre, faire maison, dégager une clairière, construire un havre - comme l'a dit Harper. Déplacer. Dissimuler. Nettoyer. Éduquer. Relocaliser. Légiférer. Frauder. Financer. Mentir. Commémorer. Reconnaître. «ll faut ce qu'il faut », comme a répondu un type du Midwest américain à l'humoriste Rick Mercer qui lui demandait lors d'un vox pop s'il était d'accord avec la décision de George Bush d'envahir la Saskatchewan. The Clearing of Estates-vieille histoire impériale.

Les monuments sont les délégués mythographiques des souverains. Des appareils sémiotiques boulonnés sur la scène patriotique, ici, à "Ottawa », dans la «capitale». Cette scène sur laquelle nous apparaissons, travaillons, jouons et aimons-confinés à des rôles de figurants sous la direction de dramaturges, metteurs en scène, puissances occultes : Héritage Canada et son bras armé, la Commission de la capitale nationale qui tracent les routes, posent les clôtures, offrent les festivals, permettent la baignade, vendent des grillades, installent des drapeaux, consultent les Algonquins, produisent des rapports - sorte de permanence événementielle à la gloire de la Couronne qui nous donne des couleurs à porter, des cas de fierté, une poitrine gonflée d'orgueil et la présentation d'excuses officielles auprès des peuples autochtones-excuses relatives au fait d'occuper avec autant d'allant ces terres que nous avons volées, mais que nous affirmons reconnaître comme les leurs avant de couper le ruban qui inaugure la prochaine transe collective de souveraineté.

Les faits d'armes poétiques de «Canada » forment une sorte de programme de recherche en études théâtrales et en mythologie occidentale :

Lumières du Nord-spectacle son et lumière - la grandiose histoire coloniale du Canada projetée sur la façade du Parlement à l'attention des touristes de partout dans le monde;

Le Festival canadien des tulipes célèbre non seulement la faveur rendue par une princesse hollandaise à qui «Canada » a accordé une clairière souveraine personnelle où accoucher d'un prince (les corps sont la nourriture des États, disions-nous), mais les vétérans de guerre canadiens, avec un «Veterans Bar \& Grill» sur le site principal; 
Le Bal de Neige, où les enfants peuvent s'amuser avec des habits militaires et des fusils d'autres époques mis à leur disposition et rencontrer des représentants des Forces armées canadiennes en uniforme munis de quelques-uns de leurs rutilants gadgets;

Le parc de la Gatineau : $361 \mathrm{~km}^{2}$ de terres expropriées dans les années 1970 - où les habitants (petits fermiers, chasseurs, pêcheurs, cueilleurs de petits fruits) Algonquins et francophones ruraux, naguère libres (libérés, oubliés) en ces terres qui vont de la ville d'Ottawa jusqu'à Masham, sont aujourd'hui soumis à des frais d'utilisation et au strict contrôle de leurs activités; et sont parfois embauchés pour rénover la plomberie des chalets dans le parc;

Le projet immobilier Zibi qui emprunte un nom algonquin pour vendre des condos de luxe sur la rivière des Outaouais à une clientèle d'academic settlers;

Le Musée canadien de l'histoire, le War Museum for the national military history et le siège social de la Monnaie royale canadienne-vecteurs sublimes de la commémoration de la souveraineté canadienne, donneurs d'emploi aux diplômés de la capitale;

La production symbolique de la guerre de 1812, précieux cadeau d'Héritage Canada aux lilliputiens agglutinés autour de la scène principale, avec sa touche cynique de diversité coloniale : Laura Secord, Tecumseh, de Salaberry, Brock-du chocolat, des Indiens canadianisés post mortem, des madames, des monsieurs et des généraux mobilisés pour les deux solitudes.

Colonial kitsch Peut-être que le paysage colonial, la réalité (outaouaise) en tant que scène principale de l'entreprise hallucinatoire de la colonisation canadienne, dans toute son extension banale et quotidienne, n'est qu'un système d'anti-monuments formant une chaîne de capture auto-itérative-le paysage de l'habituation qui ne se signifie rien, mais qui produit une archive d'expropriation que nous habitons, que nous justifions par notre simple existence : les tours de stationnement, les carrières, les parcs d'amusement, les autoroutes, les centres commerciaux, les édifices d'acier et de béton, les déchets sur les berges de la rivière. L'anti-monumentalité 
serait la forme achevée du colonialisme. Comme autant de signes pour les initiés, à la manière des pétroglyphes ojibwés : les traces sont partout, il faut savoir les lire.

"Canada» : un anti-monument dédié à la dépossession territoriale-une tradition de spoliation vertueuse : nous vous exproprions pour offrir un refuge aux victimes des monstres politiques lointains, à nos victimes du "communisme», comme l'explique Harper, aux peuples premiers et aux autres terriens, aux stupéfaits comme aux insoumis qui s'abritent dans les forêts et les vallées, les victimes de la liberté qui empruntent les autoroutes, qui magasinent au Centre Rideau, qui envoient leurs enfants s'endetter à l'Université d'Ottawa, qui regardent les touristes se balader devant le parlement ou couler dans la rivière à bord du Lady Duck, qui mangent des mets vietnamiens sur la rue Laval, qui entendent parler d'un projet de dépotoir de déchets radioactifs à Chalk River, en amont, qui organisent des pique-niques sur la plage du lac Philippe, avant que les fientes d'oiseaux la rendent toxique vers la fin du mois de juillet, qui prêtent leurs enfants aux gentils militaires le temps de boire un chai latte, qui se font parler dans un français de robot, qui vont faire un tour sur l'île Victoria, où la chef crie Teresa Spence a tenu sa grève de la faim pour protester contre les conditions de vie concentrationnaires dans les réserves fédérales:

"Dégustez, nous dit «Canada », un authentique repas autochtone comprenant de la bannique, le pain de base de nombreux peuples autochtones. Assistez en outre à un spectacle de danse et essayez-vous à l'artisanat autochtone. Si vous souhaitez faire l'expérience de la rivière des Outaouais de la même façon que les Premiers Peuples et les explorateurs la parcouraient jadis, des activités de canotage sont également offertes. Assurez-vous d'avoir un appareil photo à portée de main!»

Comme l'île Victoria, prisée des touristes, le monument (à Champlain, aux Valeureux, aux suffragettes, à la reine d'Angleterre, à Maurice Richard, à la «Maman » de Louise Bourgeois, aux vétérans autochtones) appartient à l'ère coloniale. Il est partie prenante de l'architecture de la colonisation et des jeux subversifs et populistes qu'y a instillés la modernisation contradictoire de l'idéologie nationale. Le monument correspond à l'ère héroïque de l'État 
mangeur des enfants qu'il s'est rêvé, une époque qui se définit autant par la célébration désinhibée de l'exploitation inhérente à l'édification de la nation que par l'expression d'une foi enfantine dans la pérennité des formes et de la mission civilisatrice du True North strong and free.

À cet égard, la proposition du Monument aux victimes du communisme agit comme une image dialectique : le monument est un surgissement du passé, un reflux poétique. Les ventriloques de "Canada " s'essayent à travers cette proposition, ce décret, à une expérience forte de désinhibition, niant dans un geste spectaculaire la maturation néanmoins insidieuse de la culture qui a permis de sublimer la violence coloniale dans les motifs de la reconnaissance prudente et des politesses publiques, de la célébration de soi sans la déshumanisation ouverte des autres - cette pudeur oublieuse qui fait passer le colonialisme de l'état liquide à l'état gazeux.

En même temps qu'il offrait d'envoyer gratuitement par la poste de jolies photos en couleur de la reine d'Angleterre et du Canada aux citoyens qui en feraient la demande, en même temps qu'il finançait l'occupation agressive de l'Arctique pour en sécuriser la «souveraineté », ce gouvernement a entrepris de rejouer le script de la peur du communisme, de porter son déguisement de havre de liberté pour une nouvelle Halloween des peuples. II s'est félicité auprès des usagers de la souveraineté de raconter des histoires de monstres, de fantômes, et de héros mythologiques. Harper invente le colonial kitsch, l'esthétique de l'éternel retour du colonialisme au $21^{\mathrm{e}}$ siècle. Nous sommes assis sur vous et nous sommes merveilleux-le monde est rempli de terreur. Sois libre, bel enfant.

*

Une chef algonquine invitée aux consultations publiques de la Commission de la capitale nationale en 2011, qui visait à établir un scénario collectif pour la mise en scène des célébrations du $200^{\circ}$ anniversaire du Canada en 2067, a exigé la dépollution de la rivière des Outaouais. II fallait être là pour l'entendre, car les gens responsables de la production du rapport issu de cette consultation n'ont pas cru bon de consigner cette demande, ni de la relayer.

La question de la décolonisation, aujourd'hui, consiste à trouver comment déboulonner un anti-monument. 

Events bring us together to think, create and act: a monument has been offered to us. A monument to... the victims of communism.

Before the giant's feet of clay we lay down a bouquet of questions, formulated with a desire for decolonization: What is a monument? What is a victim? What is communism? Finally, what does all this make of us, we who are gathered around the pedestal of signs?

Possession Practices in the Outaouais Valley First off, a major interrogation, a strong marker: "their victims," "these victims" or "its victims of" (communism) -is there not something of a claim to property in this? The Ojibwa literary critic of the southern Great Lakes, Gerald Vizenor/Gérald Vézina uses the terms "manifest manner,"-according to an expression in the colonial semiology he handcrafted-to describe how the claims of colonization are enacted; in an appropriative manner. "Communism," "Canada" tells us, "has" victims.

And who then, we repeat, would this "communism," this owner of "its" victims be? Moreover, who has the power to grant such ownership titles? Who is posing this (terrorist) act, this act of assigning masters?

"Throughout the $20^{\text {th }}$ century Canada became a haven for those fleeing communist governments, and a new home to those who wanted to live in freedom," the former Prime Minister of Canada, Stephen Harper stated.

Here and over there, in Ottawa, on and at the centre of the patriotic theatre of the Dominion of Canada, so far from Europe and yet so imbued with a fraternal sentiment for all the dead of human history, we are witnesses who are singled out in the revelation of a magic power: the power to grant titles, to designate, allocate, qualify. The power to curse, to cast spells. Reality is manufactured before our heavy and astounded eyes.

"Canada," speaking through the authorized ventriloquists hidden in the ceremonial spaces of the government buildings towering over the cape along the Outaouais river, allots "victims" to "communism," which becomes a major figure of the category of anthropophagic regimes. A political cosmos is made operative. Filled with nearby and faraway gods, kind and bad, this cosmos is soaked with terror, charm, wonderment, anathemas and tragic beauty. The chiaroscuro of the teratological Outaouais theatre adds an aura 
of mystery and truth - the monster has been captured, caged and offered to the people, who are "stupefied but happy" as Machiavelli said of the spectators of Cesare Borgia's crimes.

But why on earth does "Canada" want to speak to us of "communism"? To assign, involve, qualify, judge this always presumes to move through space at great speed, to plan out and build a place - by way of a mysterious and nimble gesture, wearing robes and wigs and in brandishing crowns and sceptres. In the attribution of victims to communism, in this "manifest manner," communism is a political monster that shares the body of its victims with "Canada," a sort of hallucinated boreal dervish. There is a political feast in the clearing, where the two rivers meet-the fathers ate the children they had dreamed up for themselves by telling them stories.

In the political theatre, the bodies (victims, victuals) are always manufactured in so far that they are this externality that sovereignty feeds on. The victims of communism thus captured like beavers become an exchange currency that brings legitimacy to Canada, "a haven of liberty"-bodies are the only food of States.

The Charms of the Crown The victims of tyranny, such as the "refugees of communist regimes" are presented in the rhetoric of the Memorial to the victims of communism like the champions of capitalist virtues, like Lockean colonizers who wish to identify as "Canadian." Together they form a group of powdered dolls standing still at the centre of the national showcase as they clasp little papers in their hands. Their staging is dedicated to the infinite and indefinite process of dispossession that is called "Canadian sovereignty." The Crown is a living monument-an ancient performative art.

Canadian freedom is the equivalent of the prerogative to manage human sacrifice. The power to assign victims to... To kill in order to live, as Gertrude Stein tells us in evoking what the American spirit knows and must forget in order to be able to sleep.

To kill in order to live: make a home, clear a meadow, build a haven-as Harper said. Move. Hide. Clean. Educate. Relocate. Legislate. Defraud. Finance. Lie. Commemorate. Recognize. "It takes what it takes" as the American guy from the Midwest told the comedian Rick Mercer, in response 
to his vox pop question "do you agree with George Bush's decision to invade

Saskatchewan?" The Clearing of Estates-an old imperial story.

The monuments are the mythographic delegates of the sovereigns. Semiotic apparatuses bolted on the patriotic scene, here, in "Ottawa," in the "capital." This scene on which we appear, work, play and love-confined to play the roles of extras under the direction of playwrights, directors and occult forces: Heritage Canada, and its armed wing, the National Commission, which draws up the roads, puts up fences, offers festivals, designates swimmable areas, sells barbecued meats, installs flags, consults the Algonquins, writes reports-a sort of permanent event producer to the glory of the Crown that gives us colours to wear, acts of bravery to make us swell with pride, while presenting official excuses to Indigenous peoples-excuses pertaining to the fact of so energetically occupying these lands that we have stolen, yet claim to recognize as being their own before cutting the ribbon that will inaugurate the next collective trance of sovereignty.

The poetic battle exploits of "Canada" appear as a sort of research program in theatrical studies and Western mythology:

Northern Lights Sound and Light Show-the grandiose colonial history of Canada projected on the façade of Parliament for the eyes of tourists from all around the world;

The Canadian Tulip Festival not only celebrated the returned favour of a Dutch princess to whom "Canada" granted a personal sovereign clearing where to give birth to a prince (bodies are the food of States, we were saying), but also the veterans of Canadian wars with a "Veterans' Bar \& Grill" on the main site;

The Ottawa Winterlude where children can have fun with military costumes, be provided access to rifles from other periods and can also meet uniformed representatives of the Canadian armed forces equipped with some of their shiny gadgets;

Gatineau Park, $361 \mathrm{~km}^{2}$ of land that was expropriated in the 1970s-the inhabitants (small-scale farmers, hunters, fishers, gatherers of small fruits) Algonquins, and rural francophones, who were previously given free use (liberated, forgotten) of these lands that stretch from the city of Ottawa 
to Masham are now subjected to user fees and the strict control of their activities; and sometimes they are hired to renovate the plumbing in the park cabins;

The Zibi development project which borrowed an Algonquin name to sell luxury condos on the Outaouais river to a clientele of academic settlers;

Canadian Museum of History, Canadian War Museum and the Royal Canadian Mint Headquarters - the sublime victims of the commemoration of Canadian sovereignty, job providers for the graduates of the capital;

The symbolic production of the War of 1812, a precious gift from Heritage Canada to the Lilliputians huddled around the main stage, with its cynical touch of colonial diversity: Laura Secord, Tecumseh, de Salaberry, Brockchocolate, Indians who are Canadianized post-mortem, ladies, gentlemen, and generals mobilized for the two solitudes.

Colonial Kitsch Perhaps the colonial landscape, the (Outaouais) reality as centre stage of the hallucinatory enterprise of Canadian colonisation, in all its banal and everyday extension is but a system of anti-monuments, forming a chain of auto-iterative capture - the land of habituation, meaning nothing, but which produces an archive of expropriation that we live in, that we justify by our mere existence: the parking towers, careers, amusement parks, highways, shopping centres, steel and concrete buildings, the garbage on the river shores. Anti-monumentality as the completion of colonialism. Like so many signs for the initiated, like Ojibwa petroglyphs: traces are everywhere, yet one must know how to decipher them.

"Canada": an anti-monument dedicated to territorial dispossession-a virus spoliation exercise: we expropriate you to offer refuge to the victims of far-away political monsters, to our victims of "communism," as Harper explained, to the First Nations and other earthlings, to the astounded and insubordinate who take shelter in the forests and valleys, to the victims of liberty who take the highway, who shop at Rideau Centre, who send their children to go into debt at University of Ottawa, who watch tourists stroll by the Parliament or float down the river on board of Lady Duck, who eat Vietnamese meals on Laval street, who hear about a radioactive waste dump at Chalk River, upstream, who organize picnics on the beach at lake 
Philippe, before the bird droppings make it toxic by the end of each July, who lend their children to the nice military personnel for the time it takes to drink a latte, who are spoken to in a robotic French, who can go on an excursion on Victoria island, where the Cree Theresa Spence held her hunger strike to protest against the concentration camp-like conditions in which her people live on federal reserves:

"Savour us," says "Canada," an authentic Indigenous meal including bannock, the staple bread of Indigenous peoples. Plus, you can take in a dance show and try out some Indigenous crafts. For those who want to experience the Outaouais in the way First Nations and explorers did in their day, canoeing excursions are also available. Make sure your camera is always at hand's reach!"

Like the tourist attraction that is now Victoria island, the monument (to Champlain, to the Valiants, the suffragettes, the Queen of England and Canada, Maurice Richard, Maman by Louise Bourgeois, the Indigenous veterans) belong to the colonial period. It is party to the architecture of colonization and the subversive and populist games that it has instilled in the contradictory modernization of national ideology. The monument corresponds to the heroic era of The Child-devouring-State that it dreamed up for itself, an era that is defined as much by a disinhibited celebration of the exploitation inherent in nationhood building as it is in the expression of a childish faith in the perpetuity of the civilizing forms and mission of the True North strong and free.

In this regard, the proposition for the Memorial to the victims of communism has the effect of a dialectical image: the monument is a surfacing of the past, a poetic reflux. Through this proposition, through this decree the ventriloquists of "Canada" are trying out a powerful disinhibiting experience, by way of a spectacular gesture that denies the nevertheless insidious maturation of culture which made it possible to sublimate colonial violence in the motifs of prudent recognition and public expressions of politeness; the celebration of oneself in the open dehumanization of others-this forgetful modesty that transforms colonialism from a liquid into a gaseous state.

At the same time that it offered to mail pretty pictures of the Queen of

England and Canada free of cost to citizens who requested them, at the 
same time that it financed the aggressive occupation of the Arctic to ensure its "sovereignty," this government set out to replay the fear of communism script, to wear its disguise of the "haven of liberty" for a new Halloween of the people. It has congratulated itself among the users of sovereignty for having told stories of monsters, ghosts, and mythological heroes. Harper invents colonial kitsch, the aesthetic of the eternal return of colonialism in the $21^{\text {st }}$ century. We are sitting on you, we are marvellous-the world is filled with terrors. Be free, beautiful child.

Invited to take part in the National Capital Commission public consultations held in 2011 to develop a collective scenario for the staging of the bicentennial of Canada in 2067, an Algonquin chief demanded the depollution of the Outaouais river. You had to be there to hear her, because the people responsible for the production of the consultation report did not see this request worthy of being recorded or relayed.

The question of decolonisation today consists in finding a way to dismantle an anti-monument. 


$$
\begin{aligned}
& \text { Clément } \\
& \text { de Gaulejac }
\end{aligned}
$$




\section{Tronc commun, 2015}

Matériaux mixtes, dimensions variables

Cette installation se compose d'une boîte à musique et d'une miniature de la statue de la Liberté. Le visiteur est invité à glisser une contribution volontaire dans le "tronc commun ", en échange de quoi il peut allumer une chandelle et tourner la manivelle de la boîte à musique. Le son de l'Internationale résonne alors, faisant écho à l'affiche où le personnage de Harper, grisé par sa propre liberté, entonne lui aussi le célèbre chant communiste. Ce petit monument à la monumentalité est une méditation sur le rapport à la croyance des idéologies, mais également sur la puissance de la réification allégorique et sur sa capacité à se survivre au-delà de son devenir bibelot.

Clément de Gaulejac
Mixed materials, variable dimensions

This installation consists of a music box and a miniature of the Statue of Liberty. Visitors are invited to give a voluntary contribution to the 'communal fund,' in exchange for which they may light a candle and turn the music box crank. The sound of the Internationale then plays, echoing the poster in which Harper, intoxicated by his liberty, also sings the famous communist song. This small monument to monumentality is a meditation on ideology, but also on the power of the allegorical reification of ideology and its ability to survive beyond becoming a trinket.

Clément de Gaulejac 


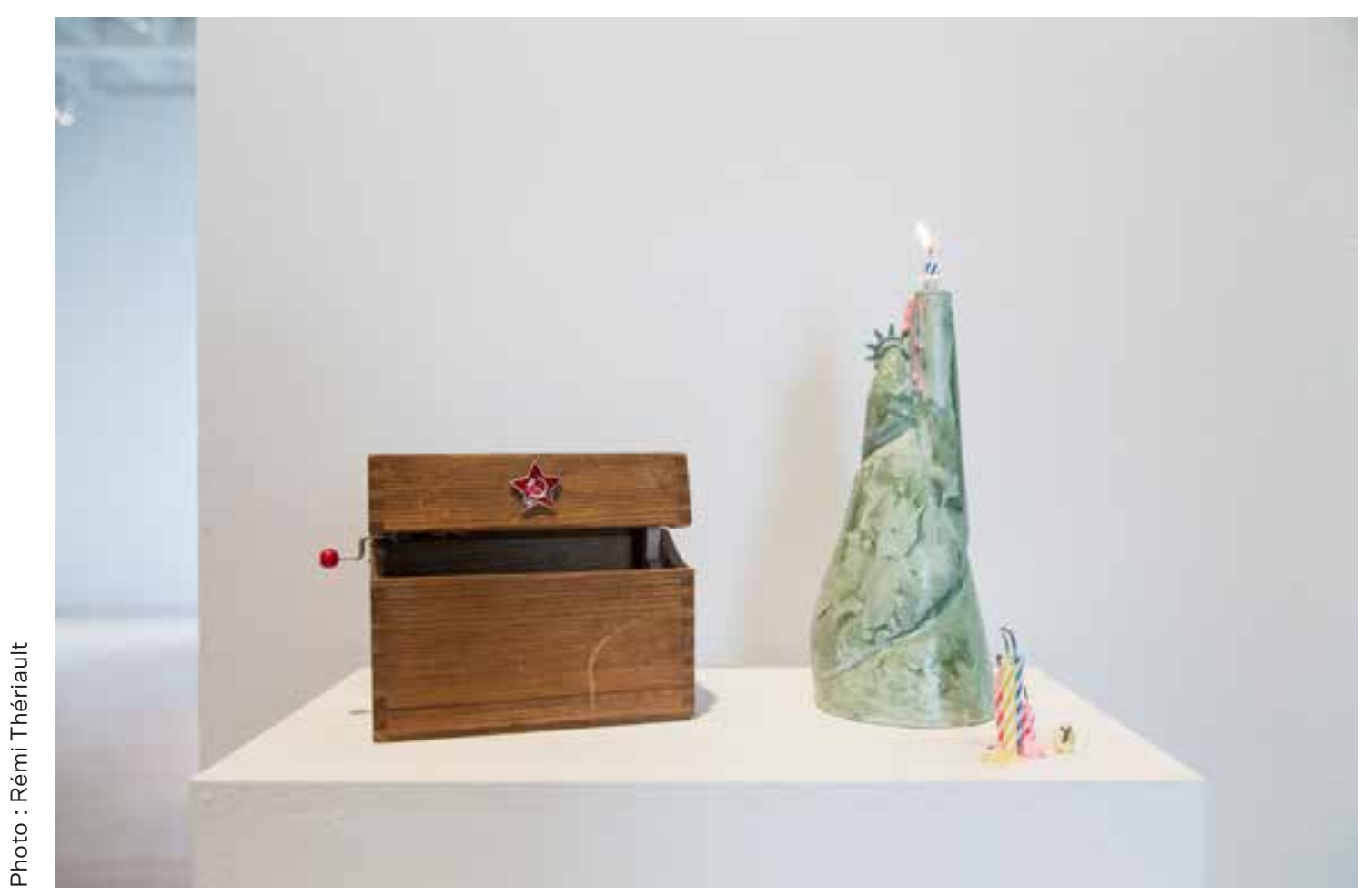




\section{Elle est belle la liberté, Pépère Canada, Miss Liberty, Génocide culturel, Chef de guerre, Disque dur, 2015}




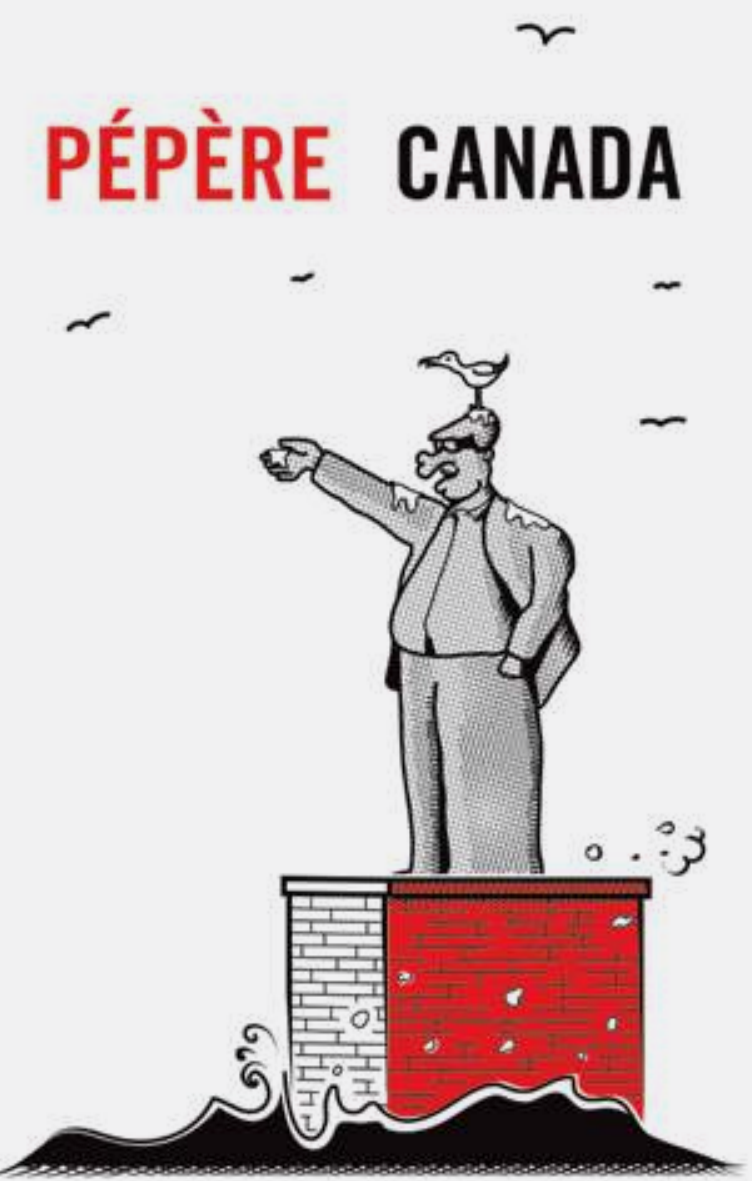


AH ELLE EST BELLE LA LIBERTÉ!

- 'Debwout of

$$
\text { les darwnés de" }
$$




\section{CHEF DE GUERRE}
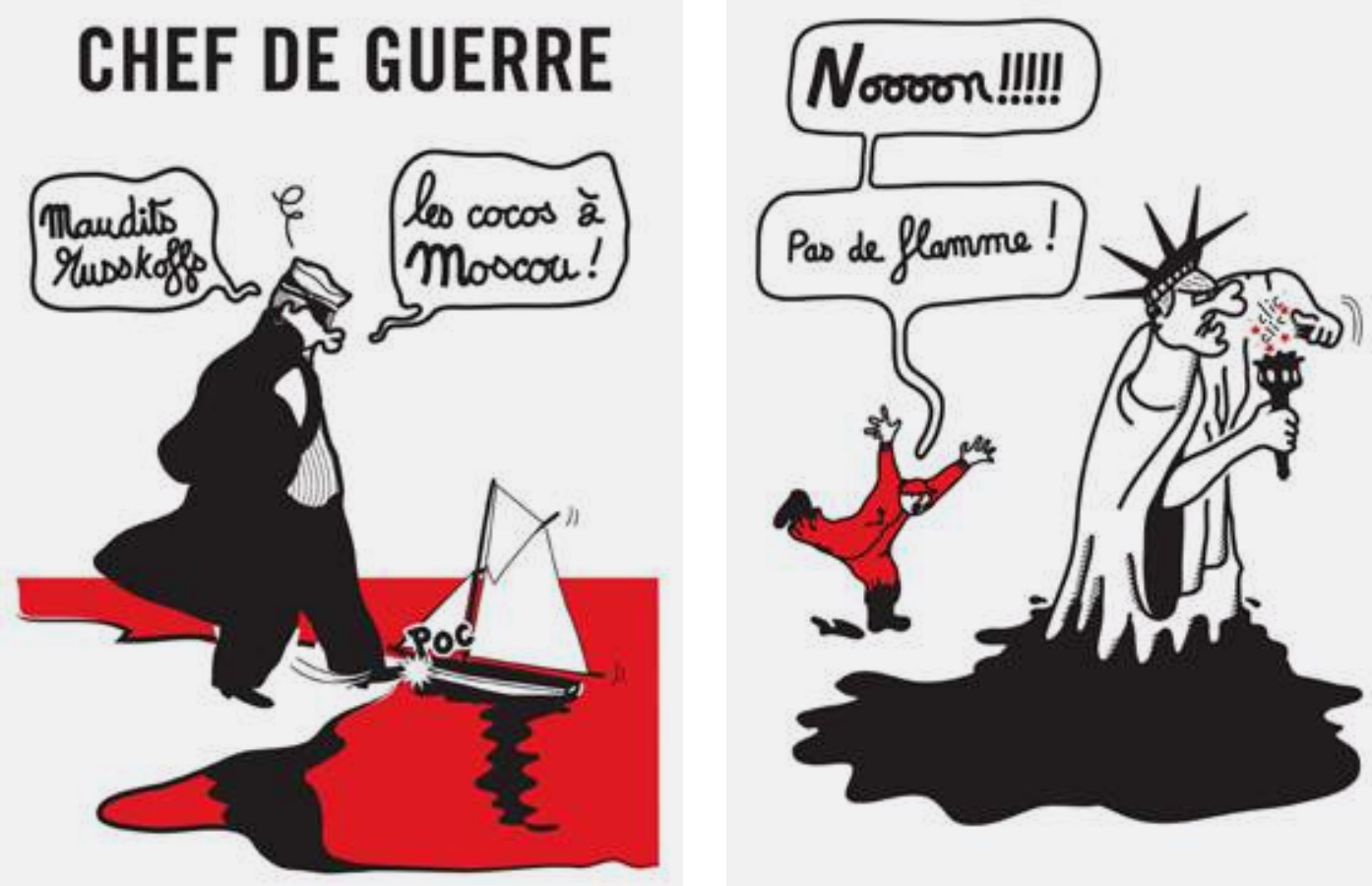

Frank

Shebageget 


\section{Communities III, 2013}

Texte manuscrit sur papier goudronné, $274 \times 488 \mathrm{~cm}$.

Communities III regroupe les noms de 719 communautés inuites et métisses du Canada qui sont en processus de réappropriation de leur langue, de leur culture et de leur territoire. Ces noms sont inscrits sur papier goudronné, un matériau isolant utilisé pour recouvrir les habitations dans de nombreuses réserves.
Handwritten text on tar paper, $274 \times 488 \mathrm{~cm}$.

Communities III names 719 Inuit and Métis communities in Canada that are in process of reappropriating their languages, cultures and territories. These names are inscribed on tar paper, an insulation material that is used to cover homes on many reserves. 


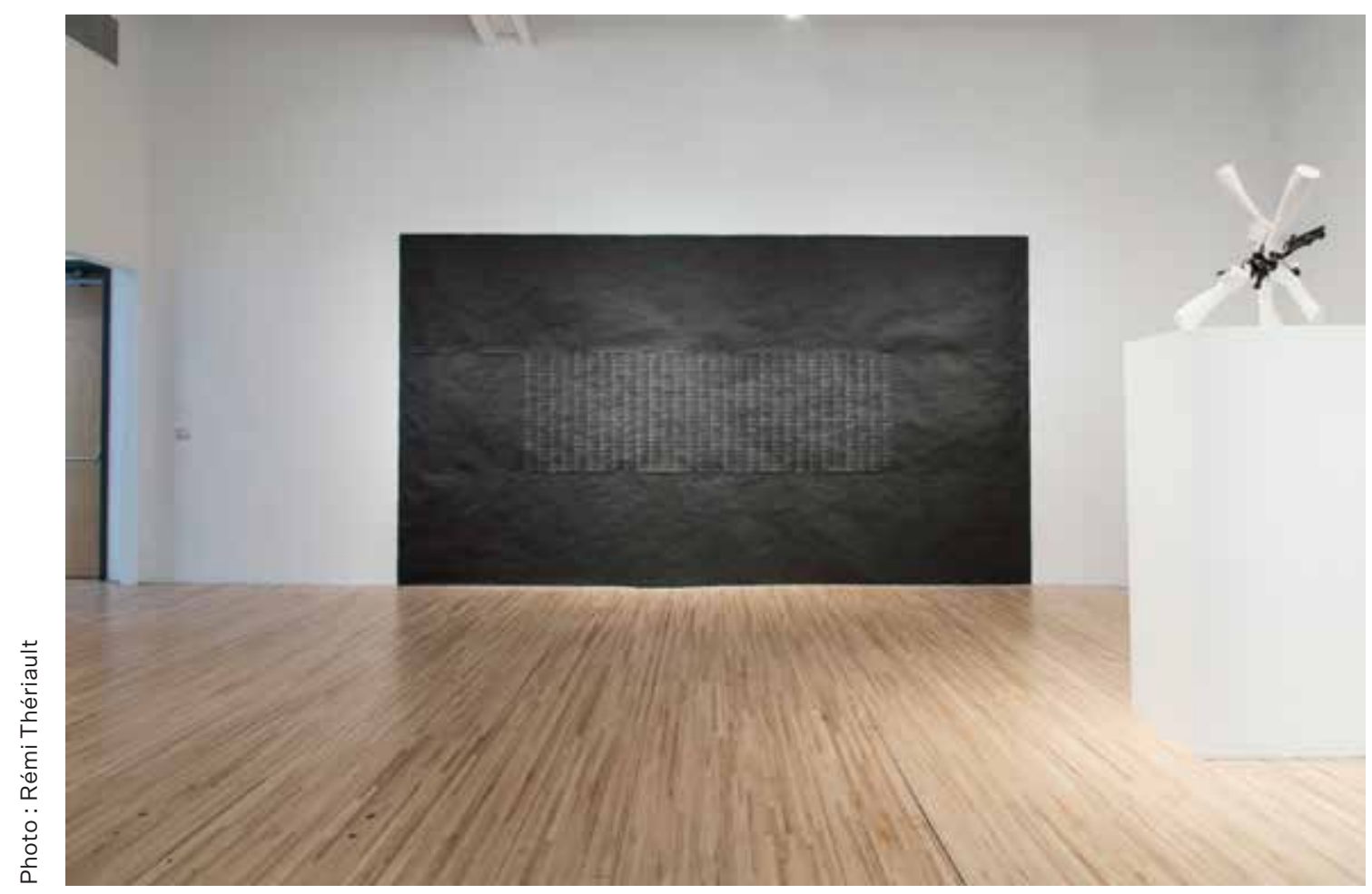




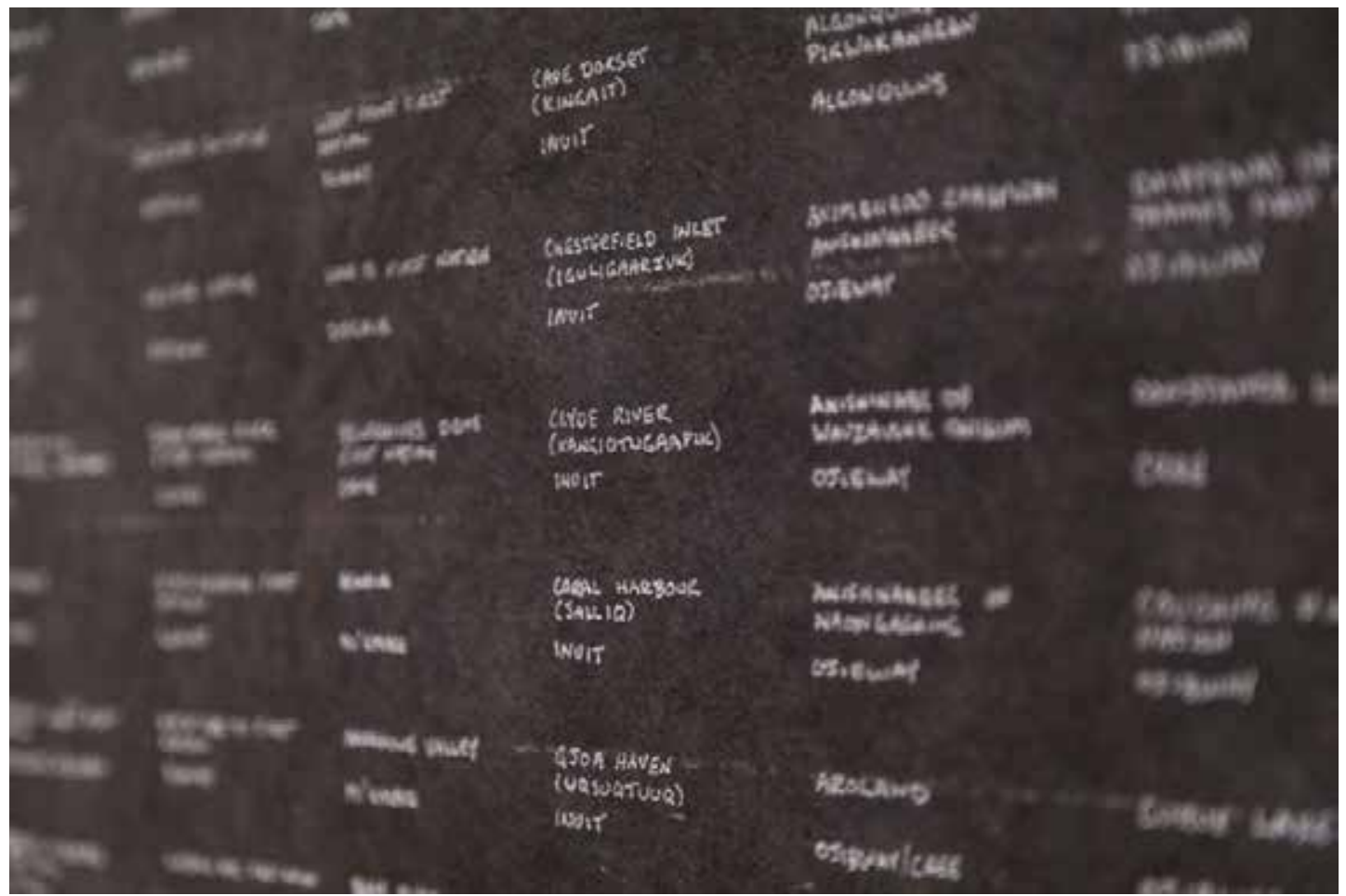


Sheena Hoszko 


\section{Segregation Unit 01 (to Scale), 2015}

Bois, gypse, ciment à joint, peinture, 2,4 × 3,7 × 2,4 m

Segregation Unit 01 (to Scale) est accompagnée d'un dépliant informatif qui décrit les conditions d'incarcération des prisonniers au Canada. Remerciements : André Beaudin, Maria F. Farah Khan, Ed Hoszko, Chuck Winter.
Wood, gypsum, joint cement, paint, $2.4 \times 3.7 \times 2.4 \mathrm{~m}$

Segregation Unit 01 (to Scale) is accompanied by an informative brochure that describes the state of prison conditions for prisoners in Canada. Acknowledgments: André Beaudin, Maria F. Farah Khan, Ed Hoszko, Chuck Winter. 


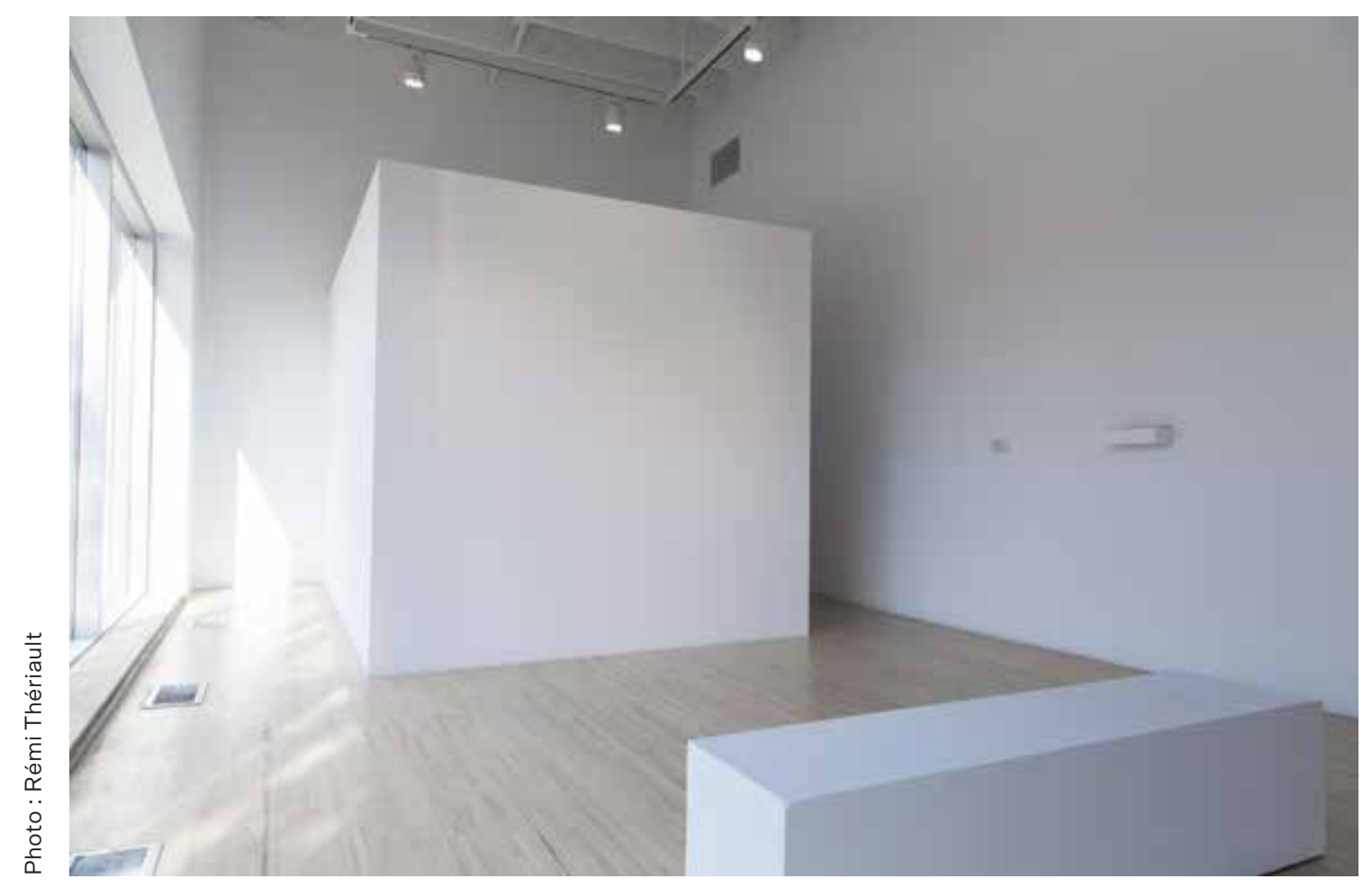




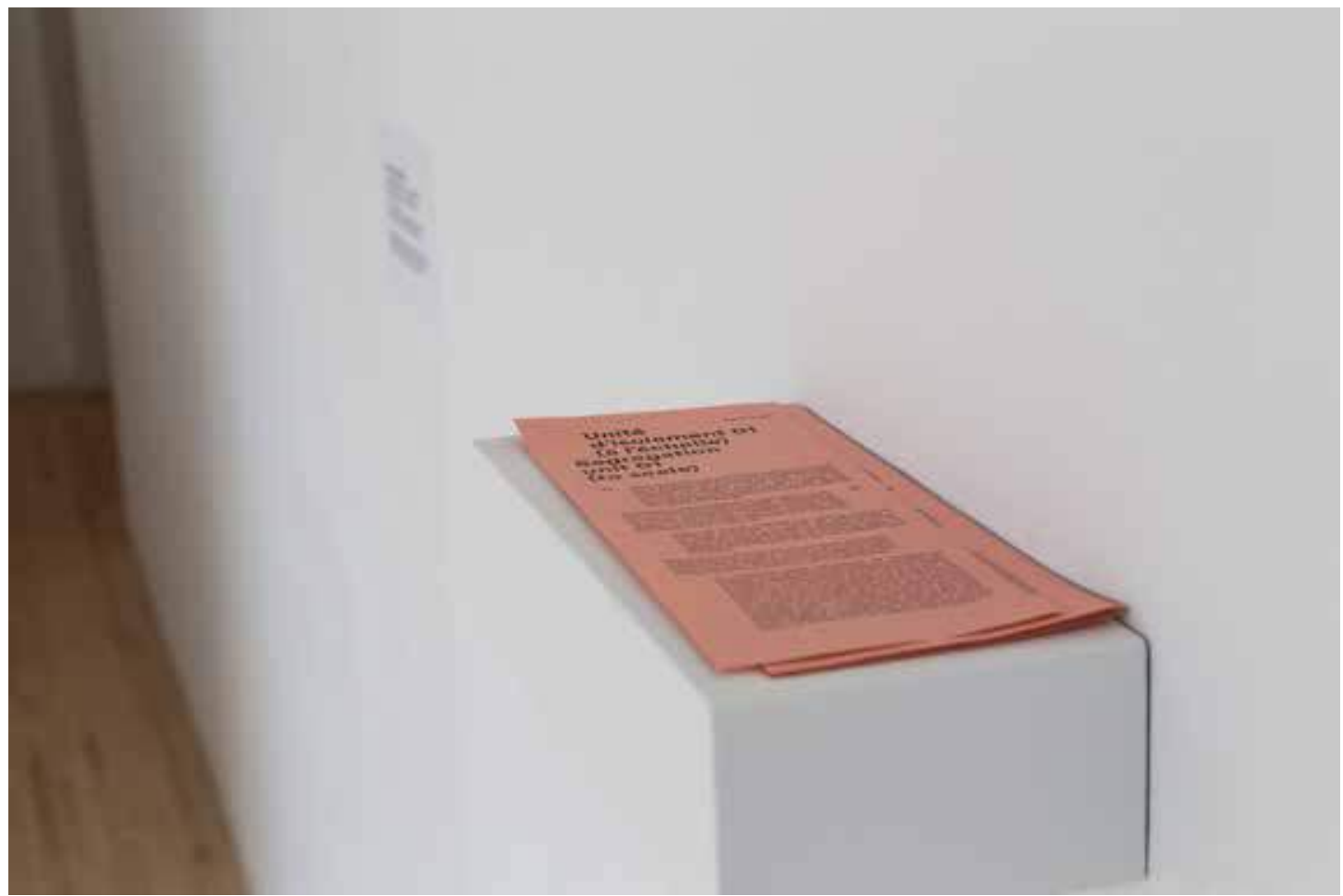


Michel

de Broin 


\section{Guerre de la liberté, 2014}

Bronze, arme à feu, composite, $67 \times 64 \times 66 \mathrm{~cm}$.

Plutôt que d'imputer les victimes aux barbaries totalitaires, le Monument aux victimes du communisme incrimine une abstraction qui n'a jamais été effective. Dans l'imaginaire idéologique polarisé de la Guerre froide, il est facile de condamner son adversaire. Mais dans un monde complexe où près d'un milliard d'armes à feu circulent librement, il est difficile de dénombrer les victimes collatérales d'une pathologie libérale. Michel de Broin
Bronze, gun, composite, $67 \times 64 \times 66 \mathrm{~cm}$.

Rather than holding totalitarian barbarisms responsible for the victims, the Monument to the Victims of Communism incriminates an abstraction that was never actualized. In the polarized ideological imagination of the Cold War, it is easy to condemn an opponent. Yet, in a complex world in which one billion firearms circulate, it is much more difficult to count the collateral damage of liberal pathology.

Michel de Broin 


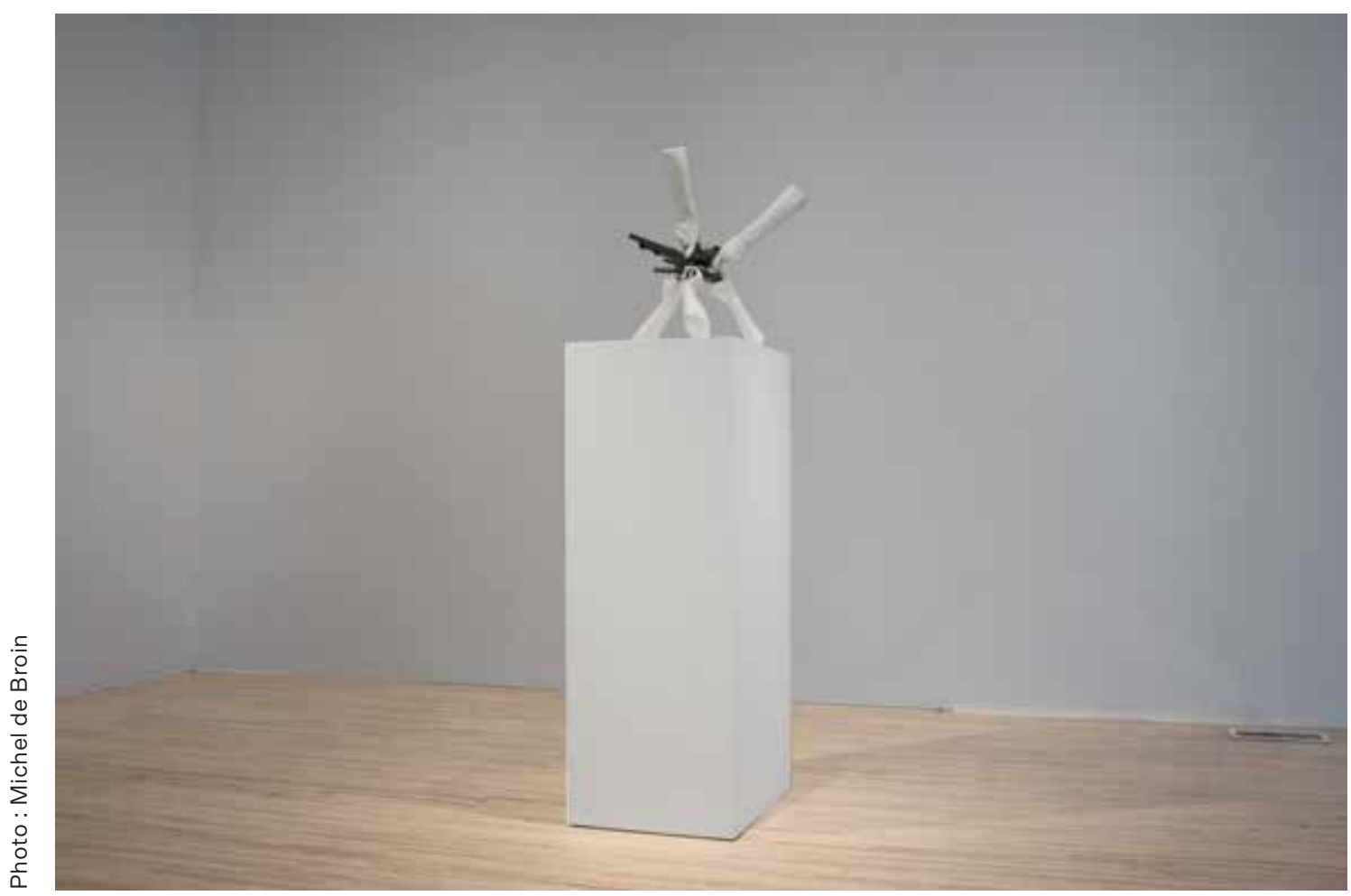




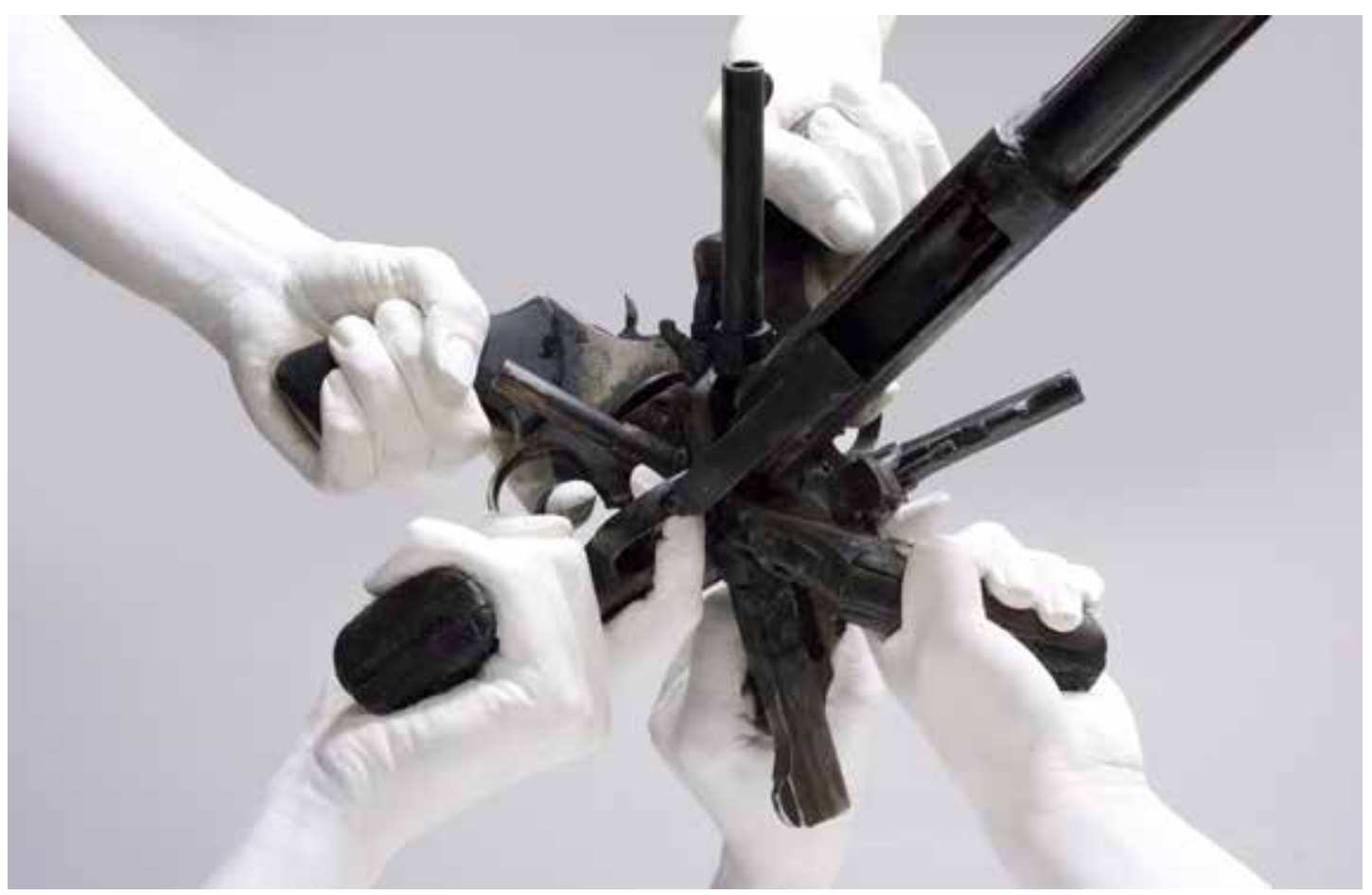




$$
\begin{aligned}
& \text { Dominique } \\
& \text { Sirois }
\end{aligned}
$$




\section{Monument du désœuvrement, 2015 Sleeping Data, 2015}

Tissus, perruque, matelas, plâtre drystone, acrylique, $170 \times 80 \times 30 \mathrm{~cm}$.

Impression couleur sur satin, sac de couchage, $195 \times 105 \times 20 \mathrm{~cm}$.

Le motif à l'intérieur du sac de couchage met en relation les courbes du Monument aux victimes du communisme et celles de diagrammes sur la pauvreté. Place du Canada apparait dans une liste sur le taux de pauvreté des pays développés. Un deuxième graphique montre la position précaire des femmes au sein de l'économie capitaliste.
Fabrics, wig, mattresses, dry-stone plaster, acrylic, $170 \times 80 \times 30 \mathrm{~cm}$.

Colour printing on satin, sleeping bag, $195 \times 105 \times 20 \mathrm{~cm}$.

The motif sewn inside the sleeping bags creates a parallel between the curves of the Memorial to the Victims of Communism and statistical graphs about poverty. One graph indicates that Canada has a high poverty rate among developed countries, while a second graph shows the precarious position of women within the capitalist economy. 


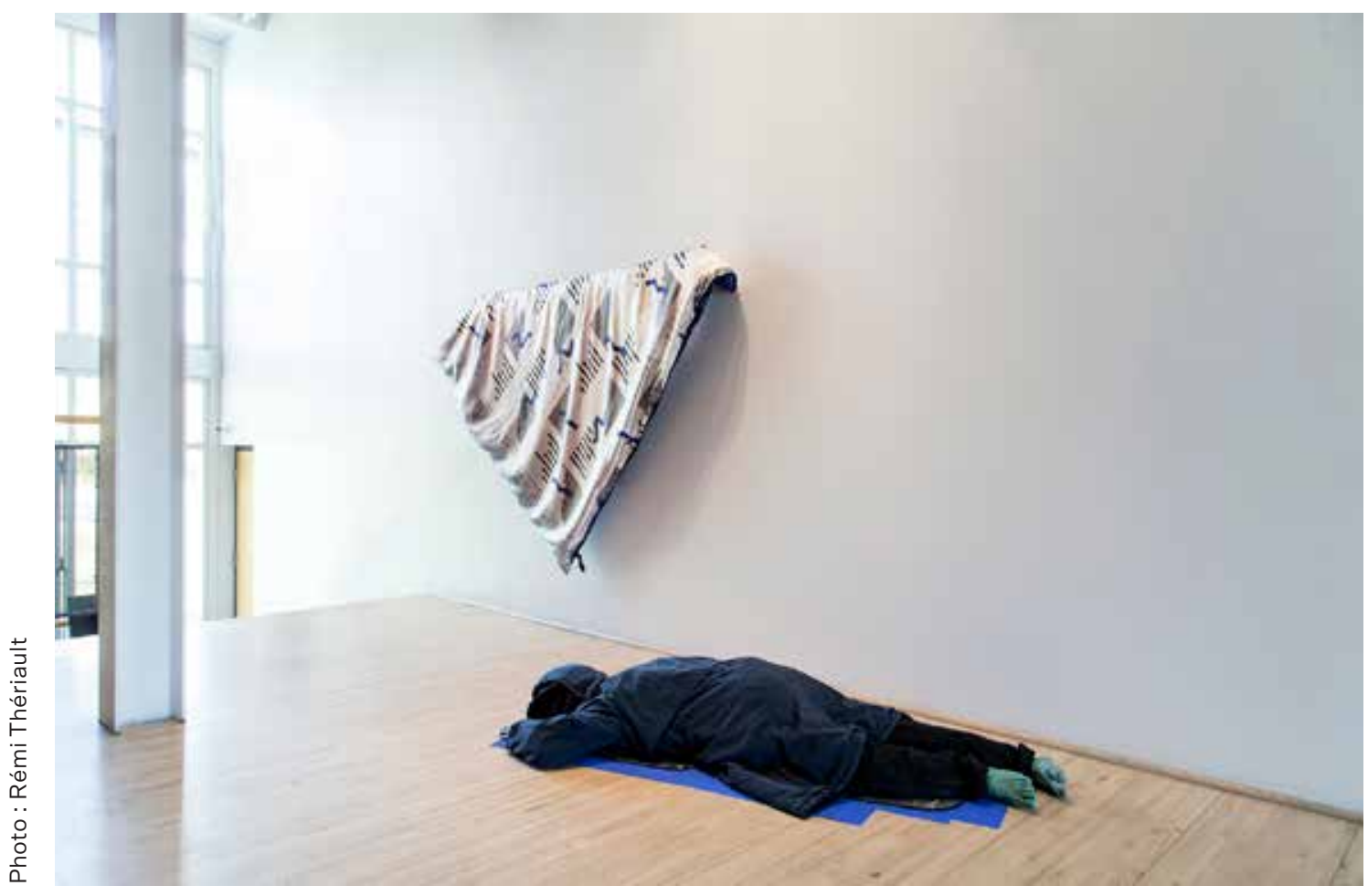




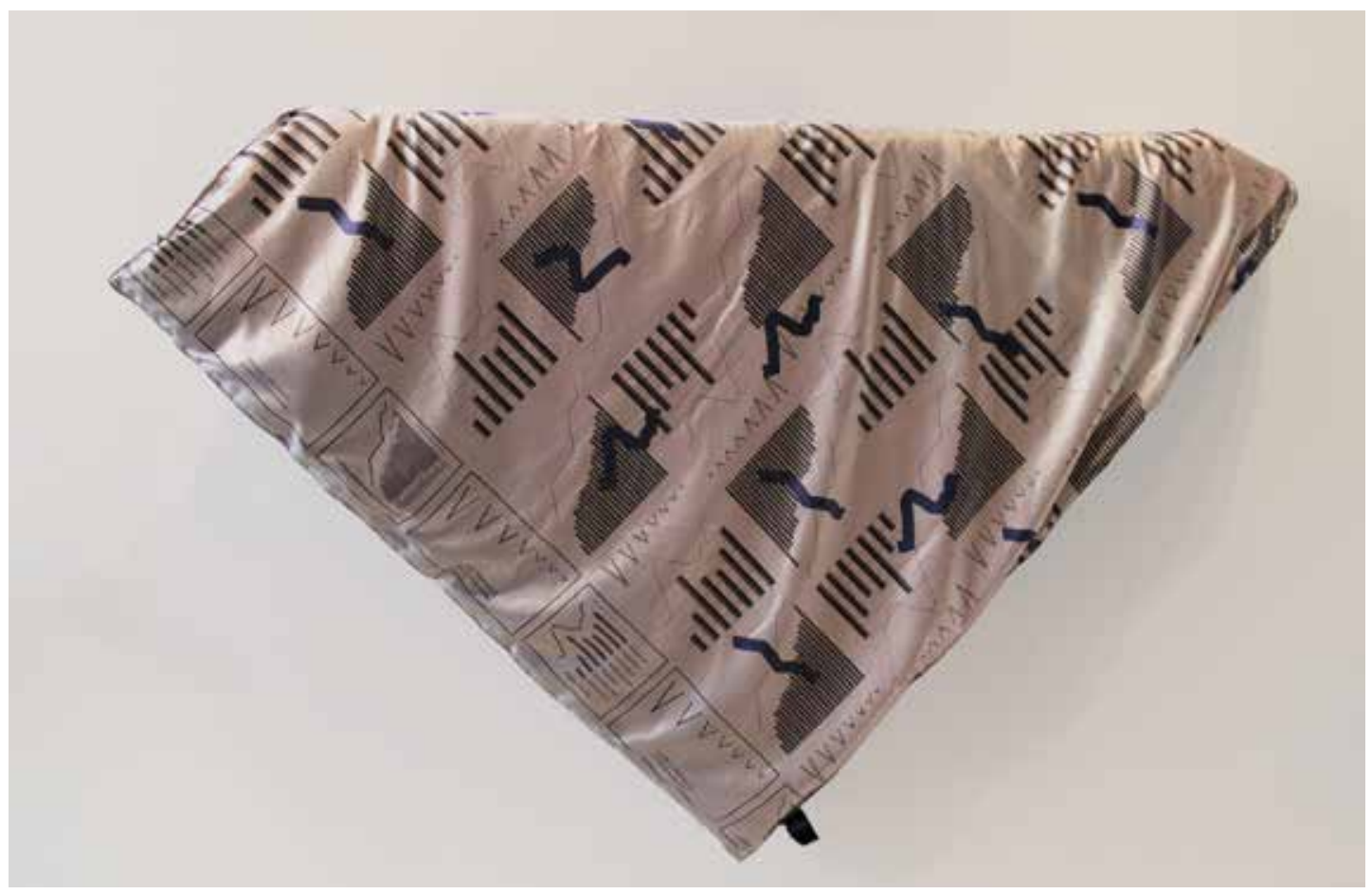




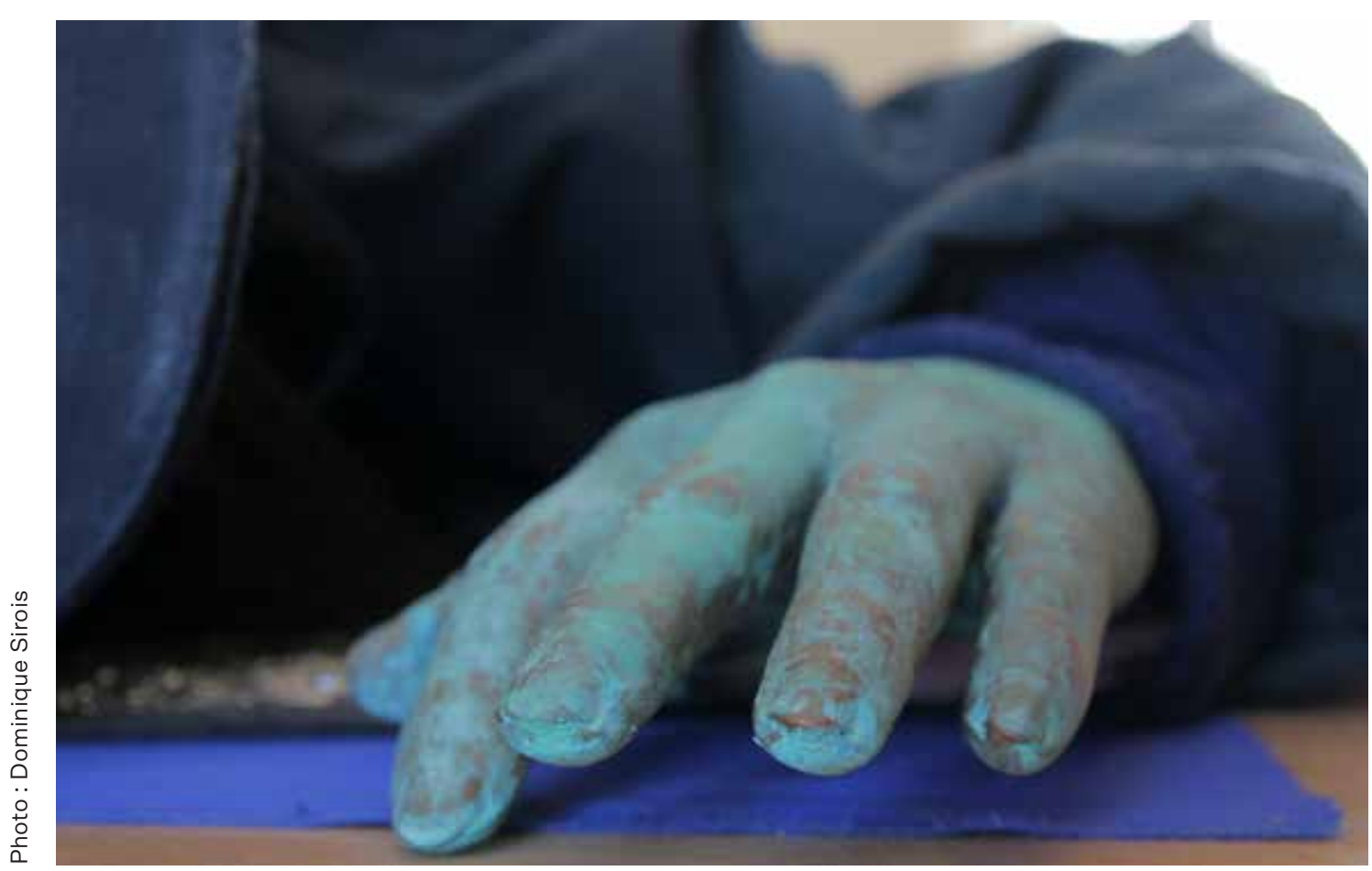





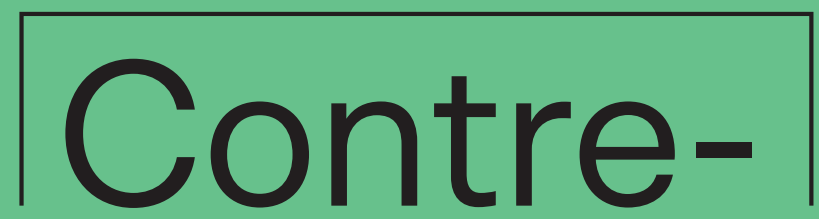

monumentalité et post-
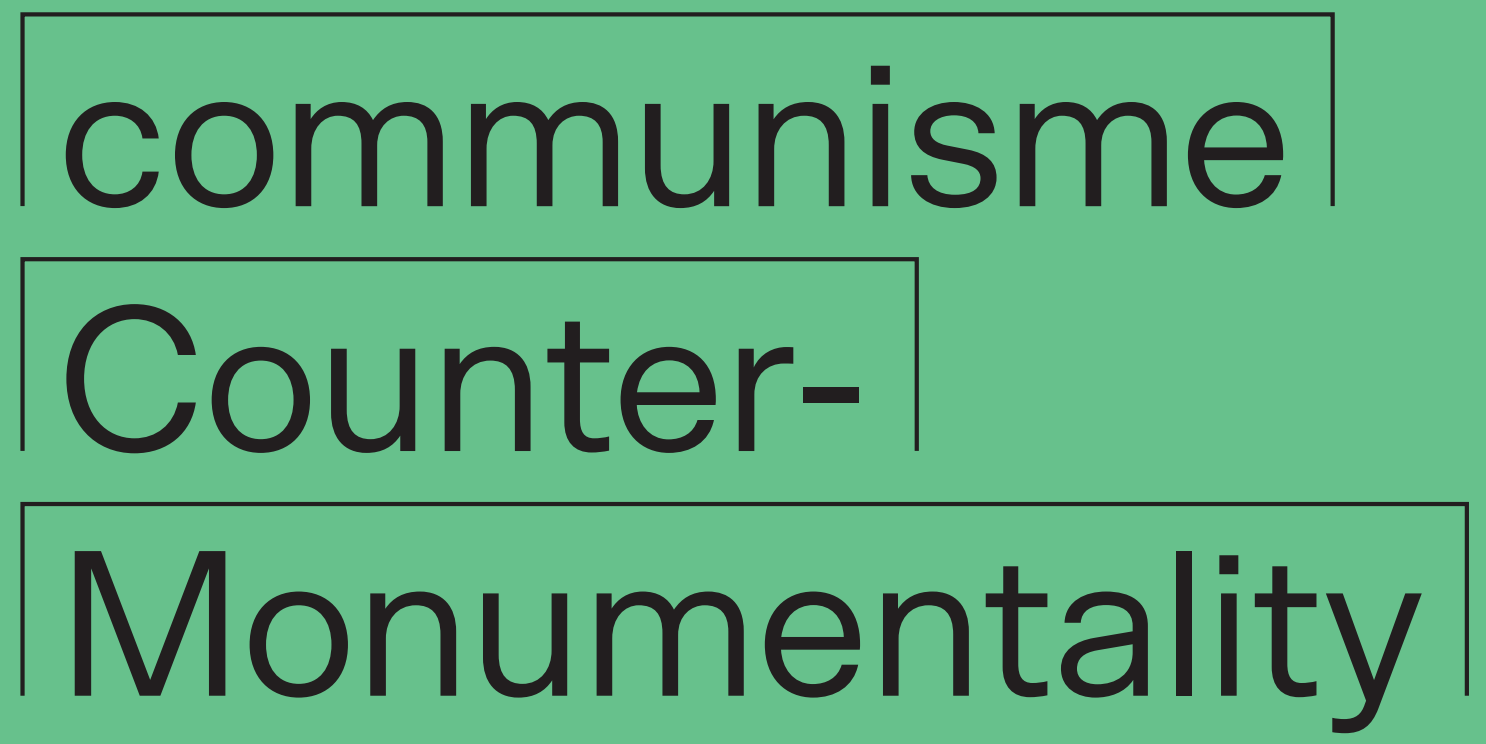

and Post-

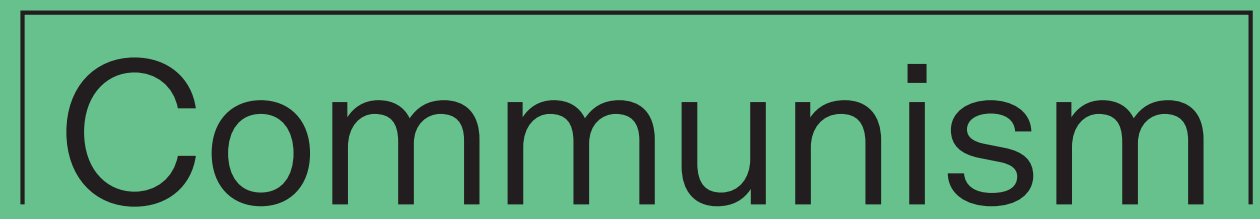



Les théories et pratiques de la contre-monumentalité sont apparues et se sont développées essentiellement en lien avec la commémoration de l'Holocauste. On peut toutefois adopter une perspective critique de la contremonumentalité en l'abordant comme un phénomène post-communiste. Comprendre la condition post-communiste des conceptions établies du contre-monument, c'est ouvrir la possibilité à d'autres conceptions de contre-monumentalité - des conceptions qui peuvent, entre autres, alimenter des critiques du post-communisme lui-même ${ }^{24}$.

La théorisation la plus connue du contre-monument provient des écrits de James $\mathrm{E}$. Young sur les monuments commémoratifs de l'Holocauste en Allemagne. D'après Young, la contre-monumentalité a pris forme dans les travaux d'artistes allemands qui souhaitaient perpétuer le souvenir de l'Holocauste, tout en étant conscients de l'héritage des monuments issus de l'Allemagne fasciste. Le recours à un mode d'expression associé au fascisme contre le fascisme a abouti, selon l'auteur, à " un monument contre lui-même : contre la fonction didactique traditionnelle du monument, contre sa tendance à altérer le passé qu'on nous présente - et enfin, contre la propension autoritariste des espaces monumentaux qui réduit l'observateur au rôle de spectateur passif ${ }^{25}$ ".

La notion de contre-monument de Young est tributaire de l'historisation formatrice de la mémoire collective par Pierre Nora dans Les Lieux de mémoire ${ }^{26}$. Inspirée de l'influente dichotomie Gemeinschaft/Gesellschaft proposée par Ferdinand Tönnies, sur laquelle repose une grande partie de la sociologie de la modernité en France, l'étude de Nora sur la culture de la mémoire s'articule autour d'une distinction entre la mémoire vivante des « milieux de mémoire » de la pré-modernité et l'histoire morte des « lieux de mémoire » de la modernité. Dans les milieux de mémoire, le passé vit dans le présent: «La mémoire est la vie, écrit Nora, toujours portée par des groupes vivants et à ce titre, elle est en évolution permanente. " En revanche, dans les lieux de mémoire, les "traces", les "signes " ou les "représentations" du passé entraînent une "délégitimation du passé vécu» et favorisent «un criticisme destructeur de mémoire spontanée ${ }^{27}$ ». «La mémoire est constamment sur nos lèvres parce qu'elle n'est plus, écrit Nora. Il existe des 
sites, des lieux de mémoire où un sentiment résiduel de continuité perdure [...] car il n'y a plus de milieux de mémoire, des contextes où la mémoire fait vraiment partie de l'expérience quotidienne ${ }^{28}$." James Young a parfaitement assimilé la distinction entre mémoire et histoire établie par Nora dans sa formulation du contre-monument. Pour Young, comme pour Nora, " en se chargeant du travail du souvenir, [le monument] soulage les spectateurs du fardeau de leur mémoire ${ }^{29}$ ". Il est essentiel, selon l'auteur, que le monument de l'Holocauste s'oppose à ce soulagement afin de retourner le fardeau au sujet humain, à qui il appartient. Young utilise le terme "contre-monument» pour décrire les monuments qui remplissent cette tâche, monuments qui «retournent le fardeau de la mémoire aux visiteurs en les forçant à jouer un rôle actif ${ }^{30}$ ». Par conséquent, le contremonument devrait, poursuit l'auteur, laisser «les visiteurs à eux-mêmes face à la mémoire, pour qu'ils sondent leurs souvenirs ${ }^{31}$ ».

Le contre-monument est pour Young un dispositif de récupération de la mémoire en tant que praxis humaine, la praxis que Nora déclare être remplacée par l'histoire, mais comprise par Young comme étant indéterminée et irrésoluble, et non pas immuable et organique comme dans les milieux de mémoire. Partant de ce point de vue, Young découvre une certaine contre-monumentalité aux monuments commémoratifs de l'Holocauste, dont la forme matérielle est en quelque sorte inversée, insaisissable, éphémère ou quelconque. En l'occurrence, le récit humaniste proposé par Nora de la mémoire vivante supplantée par les formes mortes de l'histoire se joue à l'inverse; les formes mortes-vivantes du contre-monument ravivent la mémoire sous un nouveau jour. Young valorise ce renouveau de la mémoire en tant que tel, comme si sa préservation avait une valeur en soi. II privilégie donc l'« irrésolution perpétuelle» des questions relatives à la mémoire, car c'est là la seule garantie de la «vie de la mémoire ${ }^{32}$ ". "Le contre-monument nous rappelle que la meilleure forme de commémoration de l'époque fasciste allemande et de ses victimes n'est peut-être pas le monument-mais simplement le débat qui ne sera jamais résolu sur la manière de préserver la mémoire, au nom de qui et dans quel but ${ }^{33}$." Pour Young, ce que le contre-monument met en jeu est la «perpétuation 
éternelle » de la mémoire - une substitution à l'inadéquat lieu de mémoire et une reformulation du milieu de mémoire disparu, où c'est l'irrésolution et non la résolution de la mémoire qui est permanente.

Selon Young, le débat «qui ne sera jamais résolu » sur le passé que doit initier et entretenir le contre-monument s'oppose autant à la culture du monument militarisé qu'à l'oubli. Mais ce débat peut aussi faire obstacle à l'action politique; l'horizon politique des débats non résolus est, en fait, l'horizon de la démocratie libérale post-communiste, une démocratie qui cherche à endiguer la dissension et le déni concomitant du désir ou du besoin de changement systémique ${ }^{34}$. Après 1989 et la soi-disant chute du communisme en Union soviétique et en Europe de l'Est, la notion de «fin de l'histoire " a notoirement posé la démocratie libérale post-communiste comme point final de l'évolution politique ${ }^{35}$. Le contre-monument de Young est aussi un monument à la fin de l'histoire, dans la mesure où la mémoire que le contre-monument rend irrésoluble ne peut devenir un outil politique. Quelle politique peut découler de questions touchant à la mémoire qui ne seront jamais résolues?

En tant que théoricien post-communiste de la mémoire, Pierre Nora était bien conscient de la relation entre mémoire et politique. II a contextualisé l'apparition des lieux de mémoire en France, où l'après-gaullisme sonne le glas de l'«idée révolutionnaire». Comme il l'écrit dans l'introduction de Les Lieux de mémoire : "Fin des idéologies-mémoires, comme toutes celles qui assuraient le passage régulier du passé à l'avenir ou indiquaient, du passé, ce qu'il fallait retenir pour préparer l'avenir; qu'il s'agisse de la réaction, du progrès ou même de la révolution ${ }^{36} "$. La description que donne Nora du remplacement de la mémoire par l'histoire suppose une aliénation non seulement du passé par apport au présent, mais également du futur par rapport au présent. Le «présent» qui en résulte, dont Nora se réclame en le qualifiant de réalité historique, est ni plus ni moins l'époque post-communiste d'une gouvernance post-politique dont les procédures technico-administratives remplacent à la fois la mémoire et les perspectives de changement politique ${ }^{37}$. 
En tant que théoricien de la révolution communiste, Karl Marx était également bien conscient de la relation entre mémoire et politique. Non seulement les révolutions s'orchestraient souvent autour de l'évocation anxieuse "des esprits du passé ", comme il l'expose dans le premier chapitre du 18 Brumaire de Louis Bonaparte, mais la possibilité même d'une révolution reposait sur la mémoire collective de longues luttes pour l'émancipation ${ }^{38}$. Pour Michel Foucault, comme pour Marx, la contre-mémoire est politiquement assujettie-une mémoire activement et expressément refoulée ou niée, une mémoire qui existe en relation avec des «savoirs locaux, discontinus, disqualifiés, non légitimés » qui sanctionnent des histoires afin de «les filtrer, les hiérarchiser, les ordonner au nom d'une connaissance vraie, au nom des droits d'une science qui serait détenue par quelques-uns ${ }^{39}$ ". Si le discours sur le contre-monument post-Holocauste suppose une contre-mémoire ouverte en permanence à la discussion, alors la conception de la contre-mémoire de Foucault suppose une contestation des régimes oppressifs - ou, autrement dit, de la politique.

Avec son Monument aux victimes du communisme, le groupe Hommage à la liberté fait non seulement référence à un régime oppressif, elle s'inscrit dans sa logique. Ce régime s'articule autour d'une conception tout à fait post-politique de la «liberté »-une conception de «liberté» fondée sur le "libre marché » capitaliste et la démocratie libérale en tant que véhicules de liberté pour tous. En réponse aux questions «Pourquoi une œuvre commémorative?" et "Pourquoi au Canada?", Hommage à la liberté écrit : "pour ces victimes [du communisme] et pour beaucoup d'autres, le Canada représentait - et continue de représenter - la paix, l'ordre, la démocratie, et surtout la liberté ${ }^{40}$ ». Les «autres » dont il est question ici n'incluent pas les Premières Nations, les communautés de couleur et les nombreux autres autres dont l'exclusion, le déplacement et l'anéantissement ont permis l'accueil des "victimes du communisme » au Canada - et c'est l'exclusion de ces exclusions, le déplacement de ces déplacements et l'anéantissement de ces anéantissements qui font du discours d'Hommage à la liberté sur la liberté un discours post-politique. 
Dans «Qu'est-ce qu'un auteur?», Foucault écrit que l'on «revient à un certain vide que l'oubli a esquivé ou masqué, qu'il a recouvert d'une fausse ou d'une mauvaise plénitude ${ }^{41}$ ». La « liberté», telle que la définit le groupe Hommage à la liberté, est assurément une fausse ou une mauvaise plénitude; c'est pourquoi le projet Monuments aux victimes de la liberté d'Entrepreneurs du commun peut être compris comme un retour à ce «vide " évoqué par Foucault. Dans l'exposition organisée par le collectif, il était écrit que les «contre-monuments emploient des stratégies inverses à celles des monuments conventionnels ${ }^{42}$ ». On pourrait aussi dire qu'en mobilisant une mémoire politiquement assujettie, ces contre-monuments déploient également des stratégies inverses à celles des contre-monuments traditionnels. 


\section{Post-Communist Sites}

of Counter-Memory 
Theories and practices of counter-monumentality have primarily emerged and developed in relationship to the memorialization of the Holocaust. A critical perspective on counter-monumentality, however, can instead come from approaching it as a post-Communist phenomenon. To understand the post-Communist status of received concepts of the counter-monument is to open up possibilities for other concepts of counter-monumentality-concepts that could, among other things, sustain critiques of post-Communism itself. ${ }^{24}$

The most well-known theorization of the counter-monument comes from James E. Young's writings on Holocaust memorials in Germany. For Young, counter-monumentality arose from the work of German artists who were invested in memorializing the Holocaust but also aware of the heritage of monuments in Germany's fascist past. Attempting to deploy a medium associated with fascism against fascism yielded, according to Young, "a monument against itself: against the traditionally didactic function of monuments, against their tendency to displace the past they would have us contemplate-and finally, against the authoritarian propensity in monumental spaces that reduces viewers to passive spectators." 25

Young's notion of counter-monumentality was indebted to Pierre Nora's formative historicization of collective memory in Les Lieux de Mémoire.26 Drawing upon Ferdinand Tönnies's influential dichotomy of Gemeinschaft and Gesellschaft, upon which much of the French sociology of modernity depended, Nora's study of French memory culture is organized around a distinction between the "living memory" of pre-modernity's milieux de mémoire and the dead history of modernity's lieux de mémoire. In the milieu de mémoire, according to Nora, the past lives in the present, "embodied in living societies and as such in permanent evolution," while in the lieu de mémoire, "traces," "signs," or "representations" of the past divest "the lived past of its legitimacy" and advance "a criticism destructive of spontaneous memory." 27 "Memory is constantly on our lips because it no longer exists," writes Nora; "there are sites, lieux de mémoire, in which a residual sense of continuity remains ... because there are no longer any milieux de mémoire, settings in which memory is a real part of everyday experience." 28

James Young fully assimilated Nora's distinction between memory and history in his formulation of the counter-monument. For Young, as for Nora, 
monuments, "in shouldering the memory work ... may relieve viewers of their memory burdens." ${ }^{29}$ The critical task for the Holocaust monument, according to Young, was to work against this relief and deliver this burden back to the human subject, to whom it properly belongs. Young used the term "counter-monument" to describe those monuments that fulfill this task, that "return the burden of memory to visitors themselves by forcing visitors into an active role." " 30 The effect of a counter-monument, he therefore writes, should be to leave "nothing but the visitors themselves standing in remembrance, left to look inward for memory." ${ }^{31}$

Young understood the counter-monument as a device to recuperate memory as human praxis, the praxis that Nora poses as displaced by history, but a praxis that Young understands not as unchanging and organic, as in the milieu de mémoire, but as open-ended and unresolvable. From this position, Young has discovered counter-monumentality in Holocaust memorials whose physical form is somehow negated, elusive, transient or nondescript. In these discoveries, Nora's humanist narrative of living memory becoming displaced by the dead forms of history is played out in reverse; the undead forms of the counter-monument bring memory back to life in a new form. Young valorized this revival of memory on its own terms, as if the preservation of memory was valuable in and of itself. Thus, Young privileged the "perpetual irresolution" of memory questions because only this guarantees the "life of memory." 32 "The counter-monument reminds us that the best German memorial to the fascist era and its victims may not be a single memorial at all-but simply the never-to-be-resolved debate over which kind of memory to preserve, how to do it, in whose name, and to what end." ${ }_{33}^{3}$ For Young, what's at stake in the counter-monument is the eternal perpetuation of memory - a substitution for the inadequate lieu de mémoire and a reformulation of the lost milieu de mémoire where it is memory's irresolution rather than its resolution that is permanent.

According to Young, the "never-to-be-resolved debate" about the past that the counter-monument should initiate and maintain is opposed to both a weaponized monument culture and sheer forgetting. This debate, however, can also be opposed to political action; the political horizon of unresolved debates, that is, is the horizon of post-Communist liberal democracy, a 
democracy focused on the containment of dissensus and concomitant denial of desire or need for systemic change. ${ }^{34}$ After 1989 and the so-called fall of communism in the Soviet Union and Eastern Europe, the notion of "the end of history" famously staged post-Communist liberal democracy as the terminal point of political evolution. ${ }^{35}$ Young's version of the countermonument is also a monument to the end of history insofar as the memories that the counter-monument renders unresolvable do not become available to and for politics. What politics can emerge from questions of memory that are never to be resolved?

Pierre Nora, as a post-Communist theorist of memory, was very aware of the relationship between memory and politics. Nora contextualized the emergence of lieux de mémoire in France in terms of the post-de Gaulle foreclosure of the "revolutionary idea." As he wrote in the introduction to Les Lieux de Mémoire, "Ideologies based on memory have ceased to function ... ideologies that once smoothed the transition from past to future or indicated what the future should retain from the past, whether in the name of reaction, progress, or even revolution." " ${ }^{36}$ Nora's account of the supercession of memory by history presumes an alienation not only of the past from the present, but also of the future from the present. The "present" that results, that Nora wrote within and staged as a historical reality, is nothing other than a post-Communist time of a post-political governance whose techno-managerial procedures displace both memories and anticipations of political change. ${ }^{37}$

Karl Marx, as a theorist of Communist revolution, was also well aware of the relationship between memory and politics. Not only were revolutions often organized around the anxious conjuring of "the spirits of the past," as he famously pointed out in the first chapter of The Eighteenth Brumaire of Louis Bonaparte, but the very possibility of revolution was premised on the collective memory of long struggles for emancipation. ${ }^{38}$

Like Marx, Michel Foucault posed counter-memory as politically subjugated-memory that is actively and explicitly repressed or denied, memory that exists in relation to the "local, discontinuous, disqualified, illegitimate knowledges" that sanctioned histories "filter, hierarchise and order ... in the 
name of some true knowledge and some arbitrary idea of what constitutes a science and its objects." " 39 If discourse on the post-Holocaust counter-monument suggests a counter-memory that is permanently open to discussion, then, Foucault's version of counter-memory suggests contestation with oppressive regimes of power-or, in other words, politics.

In its Memorial to the Victims of Communism, Tribute to Liberty both fits within and refers to an oppressive regime of power. This is a regime organized around a fully post-political concept of "liberty"-a concept of "liberty" that is based on capitalism's "free market" and the liberal-democratic state as vehicles of freedom for all. In response to the questions "Why a Memorial?" and "Why in Canada?," Tribute to Liberty writes that, "for these victims (of Communism) and many others, Canada represented-and continues to represent-peace, order, democracy, and above all liberty." 40 The "others" referred to here do not include First Nations, communities of color, and the many other others whose exclusion, displacement and annihilation created the very ground upon which the "victims of Communism" have been welcomed in Canada-and it is just the exclusion of these exclusions, the displacement of these displacements, and the annihilation of these annihilations that render Tribute of Liberty's discourse on liberty post-political.

In "What is an Author?," Foucault writes of "returning to those empty spaces that have been masked by omission or concealed in false and misleading plentitudes." 41 "Liberty," as framed by Tribute to Liberty, is certainly a false and misleading plentitude; Entrepreneurs du commun's project Monuments to the Victims of Liberty, then, can be understood as a return to one of the "empty spaces" noted by Foucault. Entrepreneurs du commun writes that, in its exhibition, "counter-monuments deploy strategies that are the reverse of those used by conventional monuments." ${ }^{42}$ But in their engagement with politically subjugated memories, those counter-monuments could be said to deploy strategies that are the reverse of those used by conventional counter-monuments, as well. 

Milutin

Gubash 


\section{A Proposal for a Monument That is Not Really There, 2015}

Plaque de bronze, $35,6 \times 45,7 \mathrm{~cm}$.

Milutin Gubash est un artiste d'origine serbe. Ses œuvres, qui combinent aussi bien la fiction et la réalité que le passé et le présent, s'intéressent à la construction de l'identité individuelle et collective. Elles mettent le plus souvent en scène son histoire personnelle et celle des membres de sa famille. Dans le cadre de cette exposition, l'artiste a fixé de manière permanente une plaque sur un des murs arrières de La Filature. Cette plaque commémore la détermination et l'illusion des nombreux immigrants qui, comme les parents de Gubash, ont quitté un pays pour un autre.
Bronze plate, $35.6 \times 45.7 \mathrm{~cm}$

Gubash is an artist of Serbian origin. His works, which combine fiction with reality as well as past and present, question the construction of individual and collective identity. They often showcase a staging of his personal history and that of his family members. As part of this exhibition, the artist has installed a permanent plaque on one of the outer walls of the building. It commemorates the determination and the illusion of the many immigrants who, like his parents, left their country for another. This work is located outside on the rear wall of La Filature. 


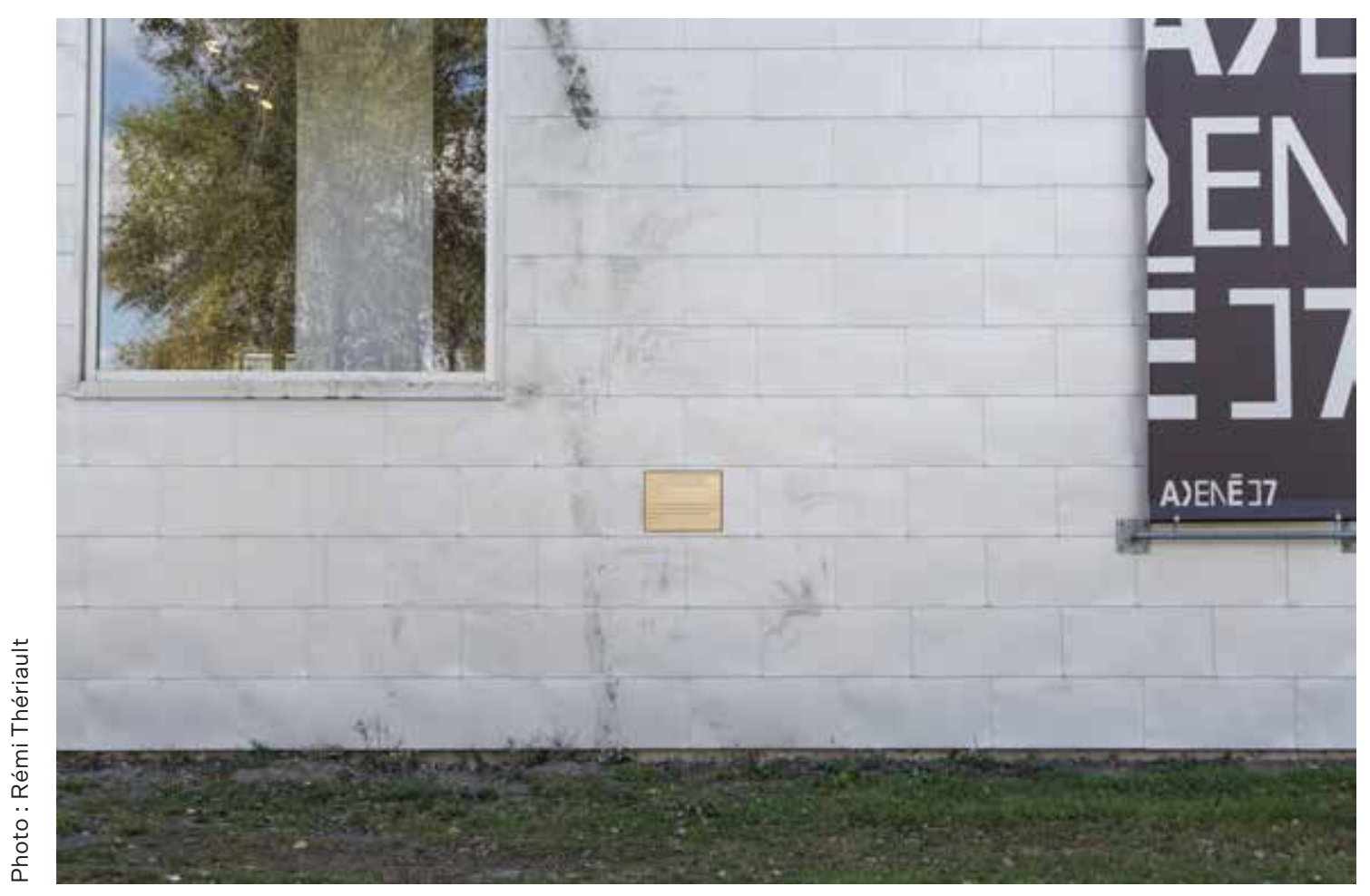




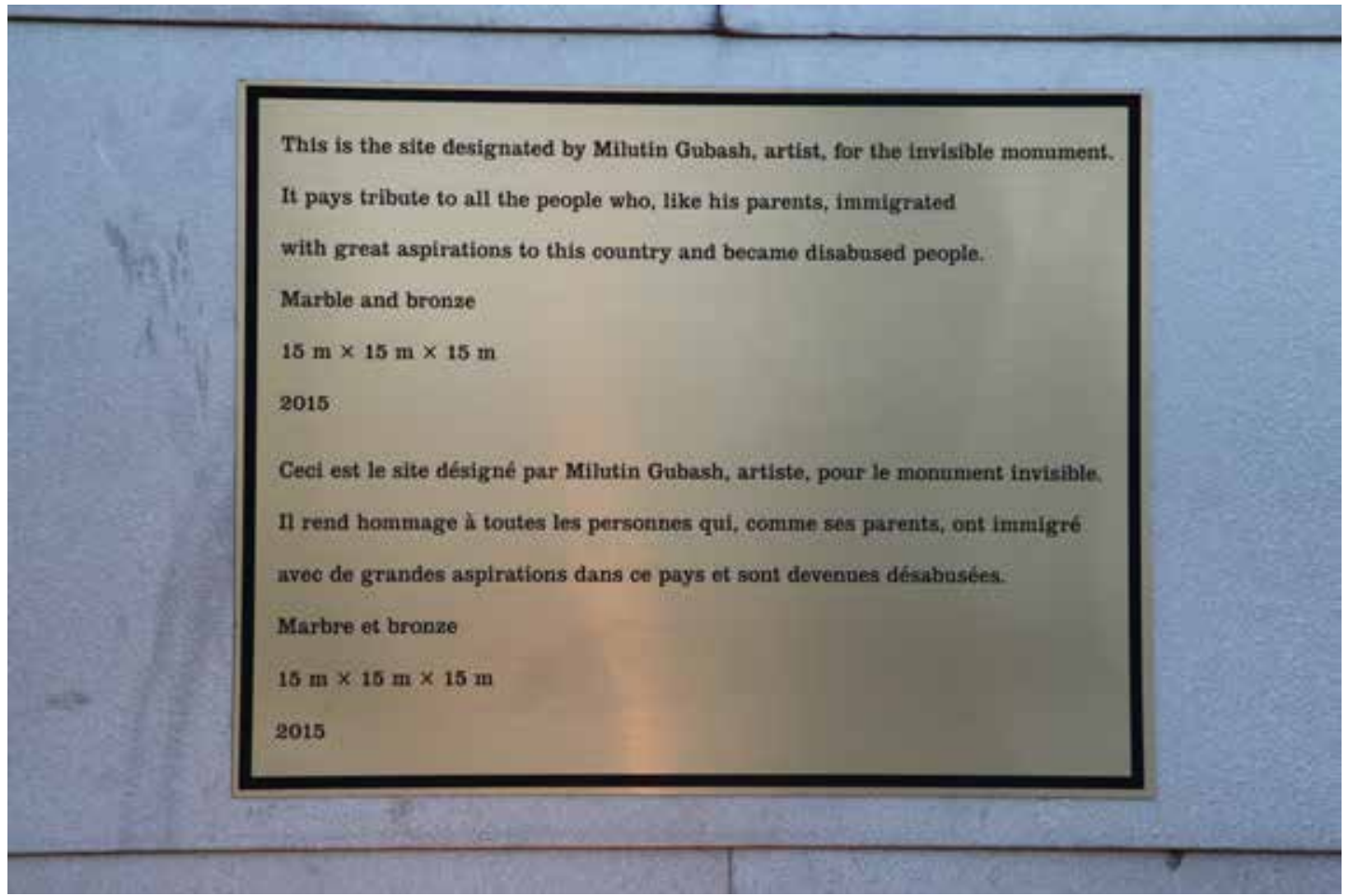




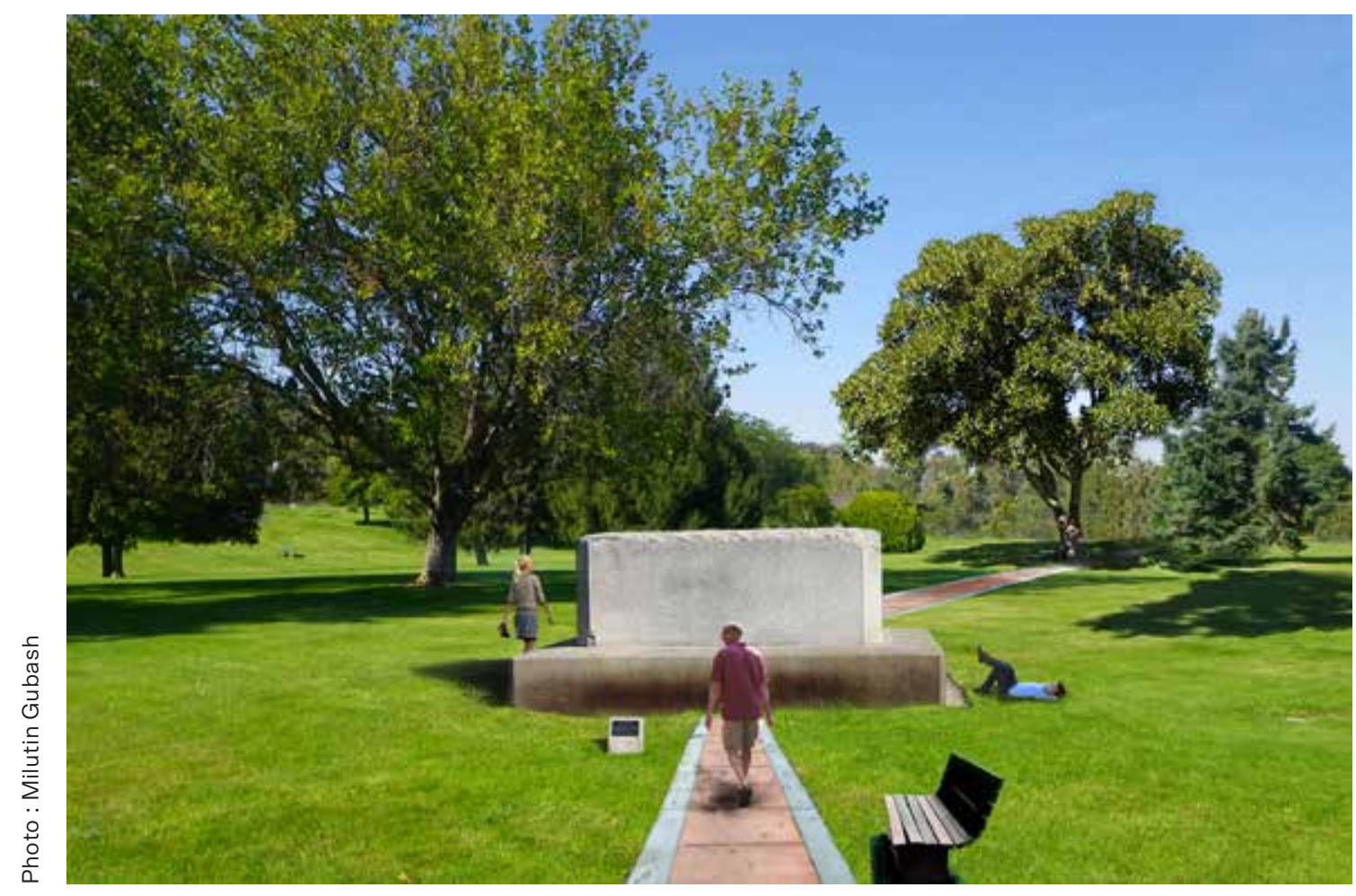



Étienne Grenier et Simon Laroche

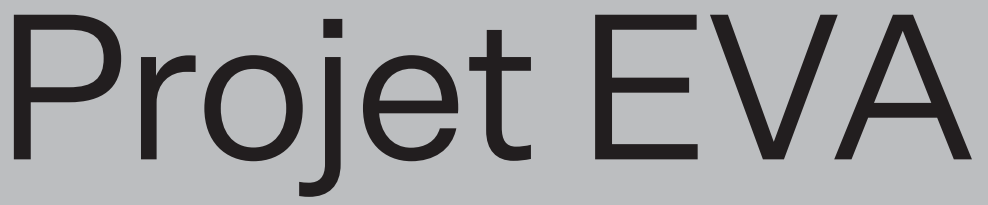




\section{Micro-monuments souvenirs (Bientôt en vente!). Archives de production, 2015}

Matériaux mixtes, dimensions variables Aide à la fabrication: Raphael Demers

L'œuvre présente les fiches nécrologiques de 28 individus décédés entre 1839 et 2014 aux mains des forces policières ou à la suite de décisions judiciaires dans le contexte de démocraties libérales. Ces individus sont morts pour leurs convictions politiques. Leurs noms ont été gravés sur un ensemble de micro-monuments constitués de deux parties qui s'emboitent parfaitement, et dont la forme reprend celle du Monument aux victimes du communisme.

Les micro-monuments présentés dans l'exposition sont les maquettes de pièces qui devaient éventuellement être produites en série et vendues sur le site du Monument aux victimes du communisme.
Mixed materials, variable dimensions Technical support: Raphael Demers

The obituary records of 28 individuals who died between 1839 and 2014 are exposed. These people died at the hands of police or following the decisions of the judiciary in the context of liberal democracies. These people died for their political beliefs. Their names were engraved on a set of micro-monuments made of two interlocking parts, mirroring the shape of The Memorial to the Victims of Communism.

The micro-monuments displayed in the exhibition are the prototypes of the pieces that were eventually to be mass produced and put up for sale on the site of the The Memorial to the Victims of Communism. 


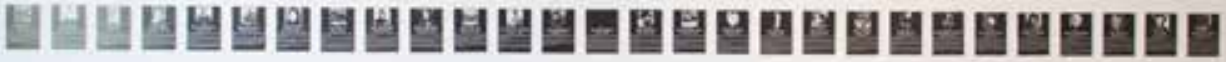

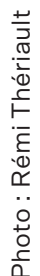

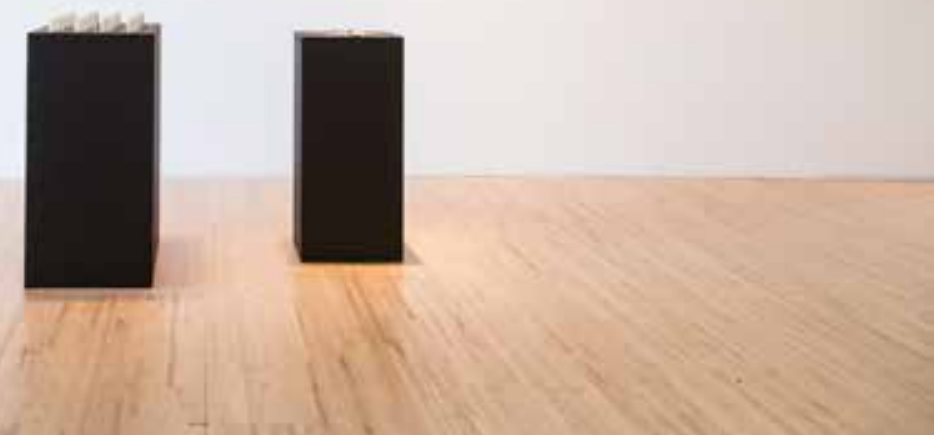




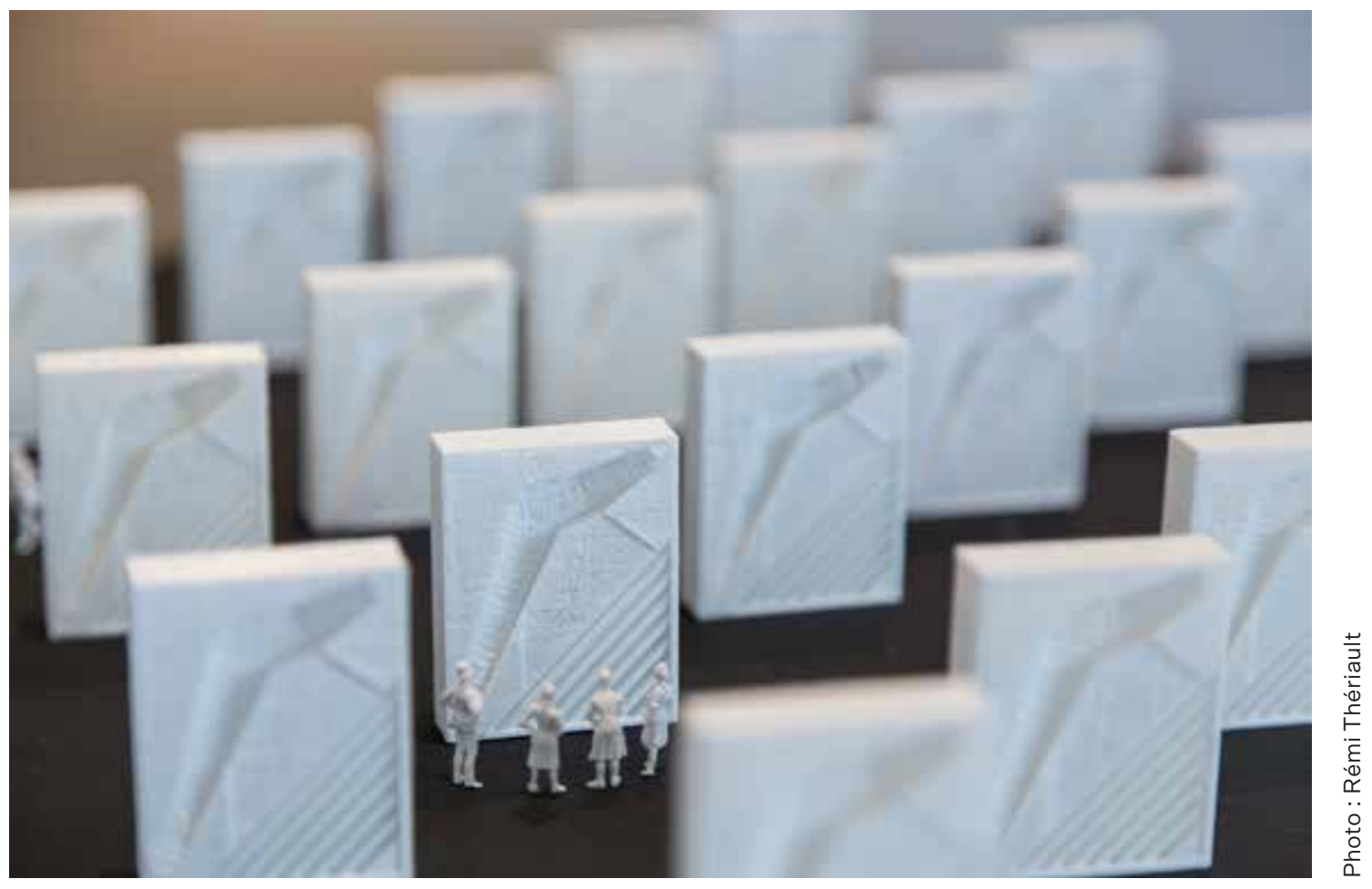



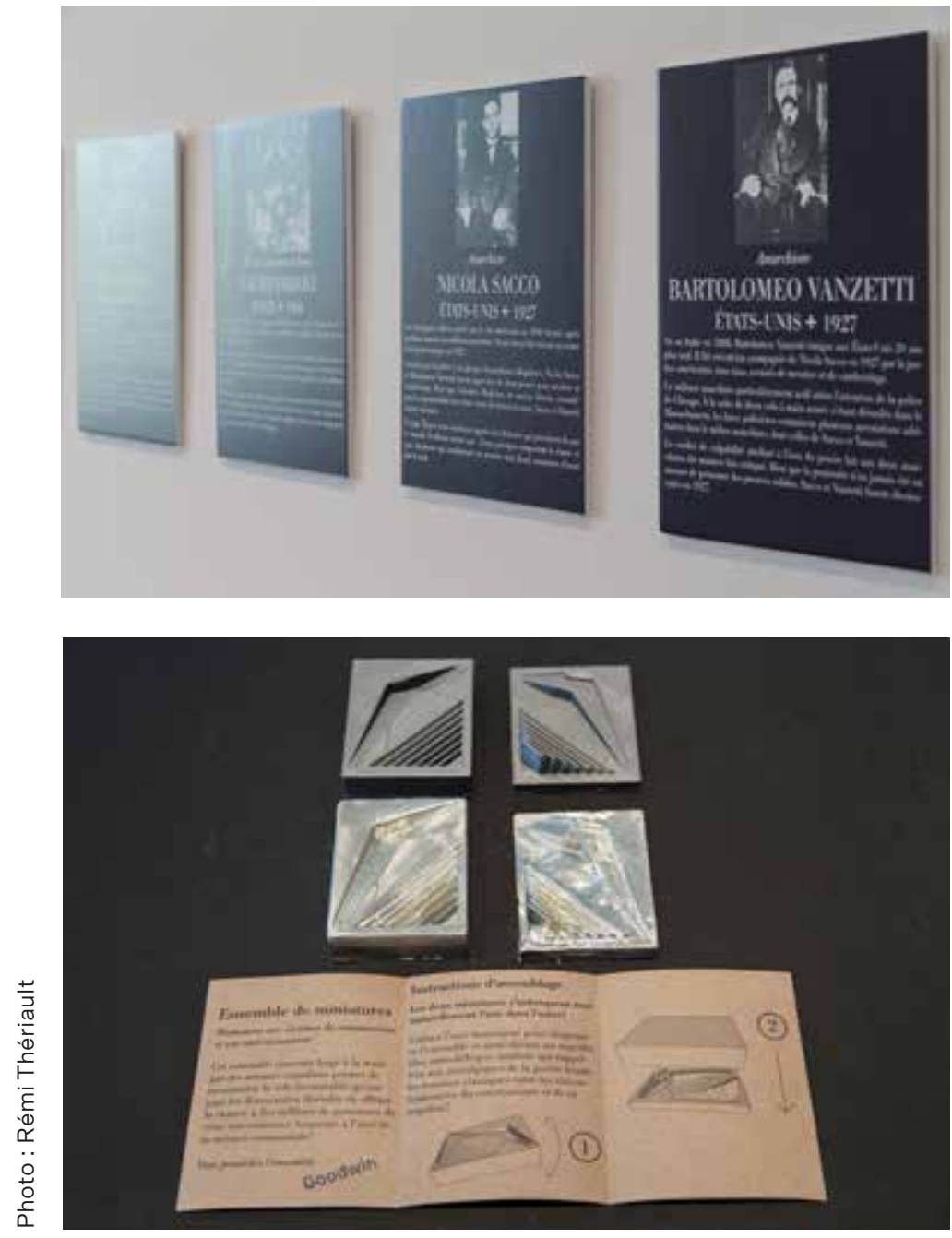



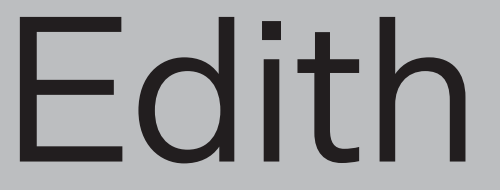

Brunette 


\section{Contre-monument à 100 millions de brins d'herbe identiques, 2015}

Maquette pour un projet d'intervention. Matériaux mixtes, dimensions diverses.

Le projet s'inspire de l'histoire oubliée des jardins de la Victoire, ces dizaines de milliers de potagers qui ont vu le jour sous l'impulsion des gouvernements canadiens, étatsuniens, britanniques et autres pour pallier à la pénurie alimentaire pendant la Première et la Seconde Guerre mondiale. Contre-monument a consisté à recueillir des semences auprès d'organismes et d'individus tournés vers une approche alternative de l'agriculture, qui mettent en pratique le partage des savoirs, la préservation d'un patrimoine commun et l'action collective. Ces graines ont ensuite été semées, au cours d'une performance collective, dans la pelouse impeccable entourant le site du futur monument. II s'agissait de créer un contre-monument végétal évoquant d'autres formes de ce que peut vouloir dire, aujourd'hui, le terme communisme. Remerciements : François Lemieux, Michael Caffrey (impression), Pablo Rodriguez (traduction) et AXENÉO7.
Model for an intervention.

Mixed media, variable dimensions.

The project is inspired by the forgotten history of Victory gardens. These consisted of dozen of thousands of vegetable gardens that were created thanks to incentives by the Canadian, US and British governments to remedy the food shortage during World War I and World War II. Contre-monument consisted of collecting seeds from organizations and individuals devoted to alternative agricultural approaches that mobilize knowledge sharing, the conservation of a common heritage and collective action. During a collective performance, these seeds were then sown on the impeccable lawn surrounding the site of the future memorial. It was about creating a vegetal counter-monument that evokes other forms of what the term communism can stand for nowadays. Thanks: François Lemieux, Michael Caffrey (for printing), Pablo Rodriguez (for translation), AXENÉO7. 


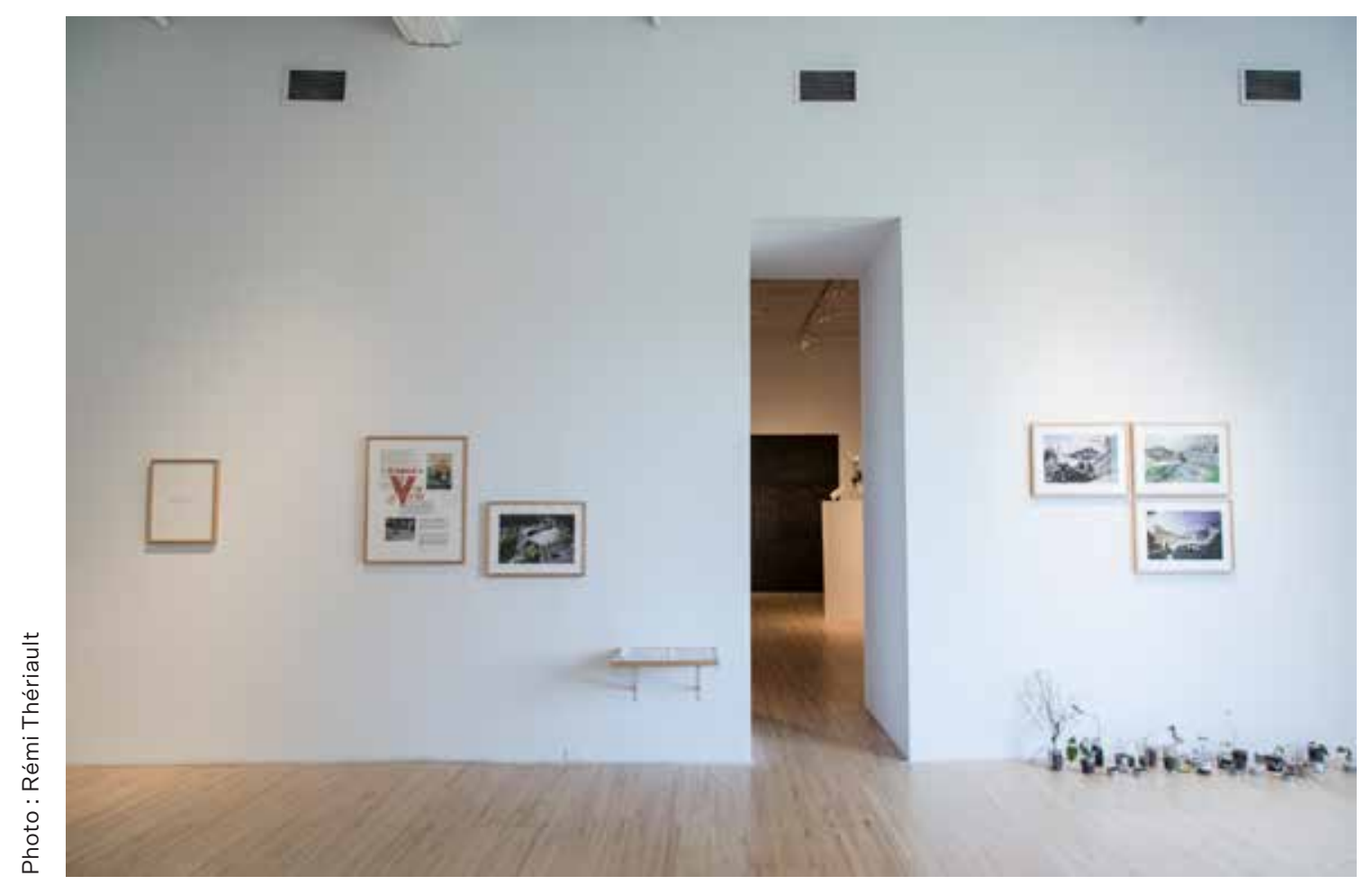



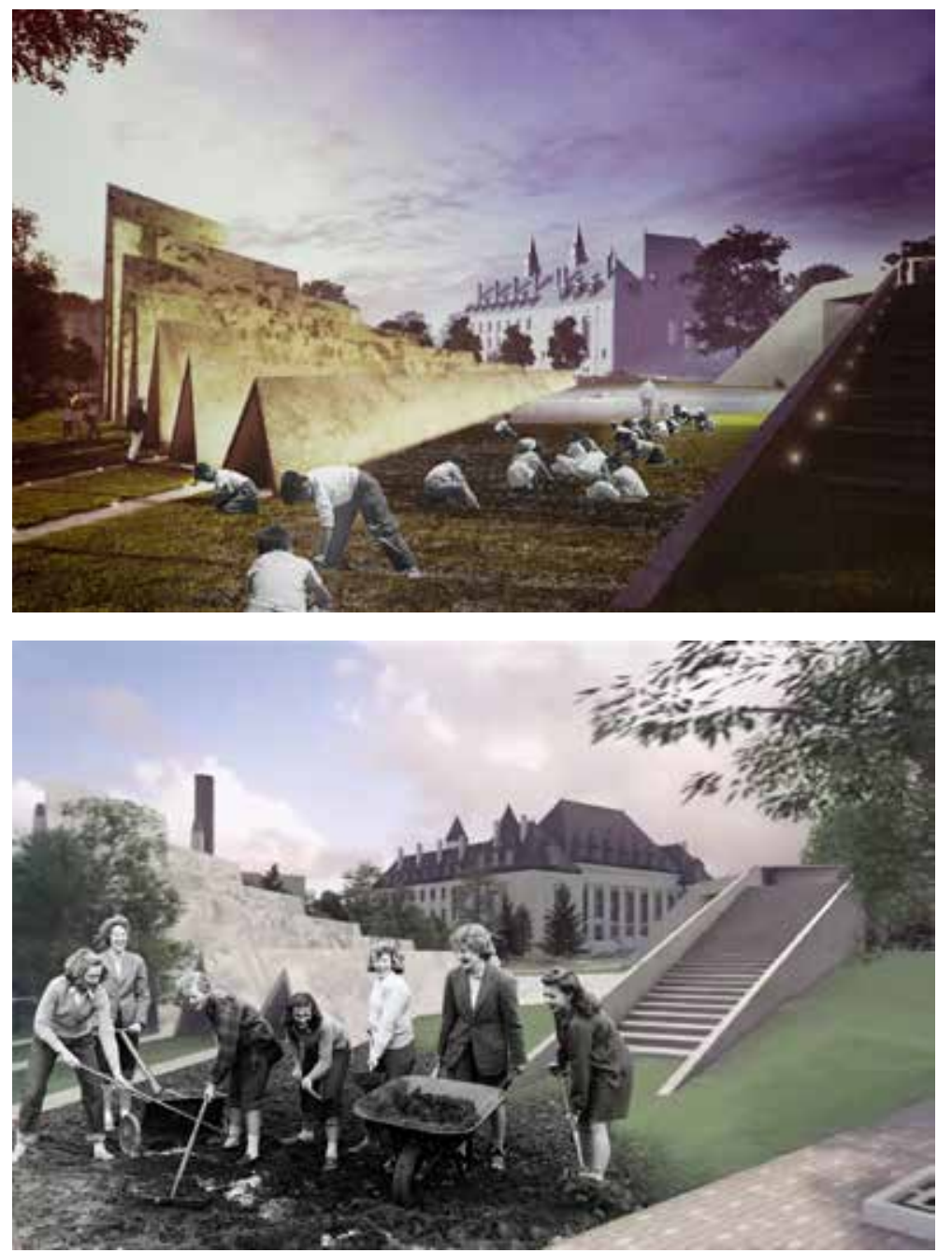

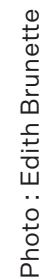



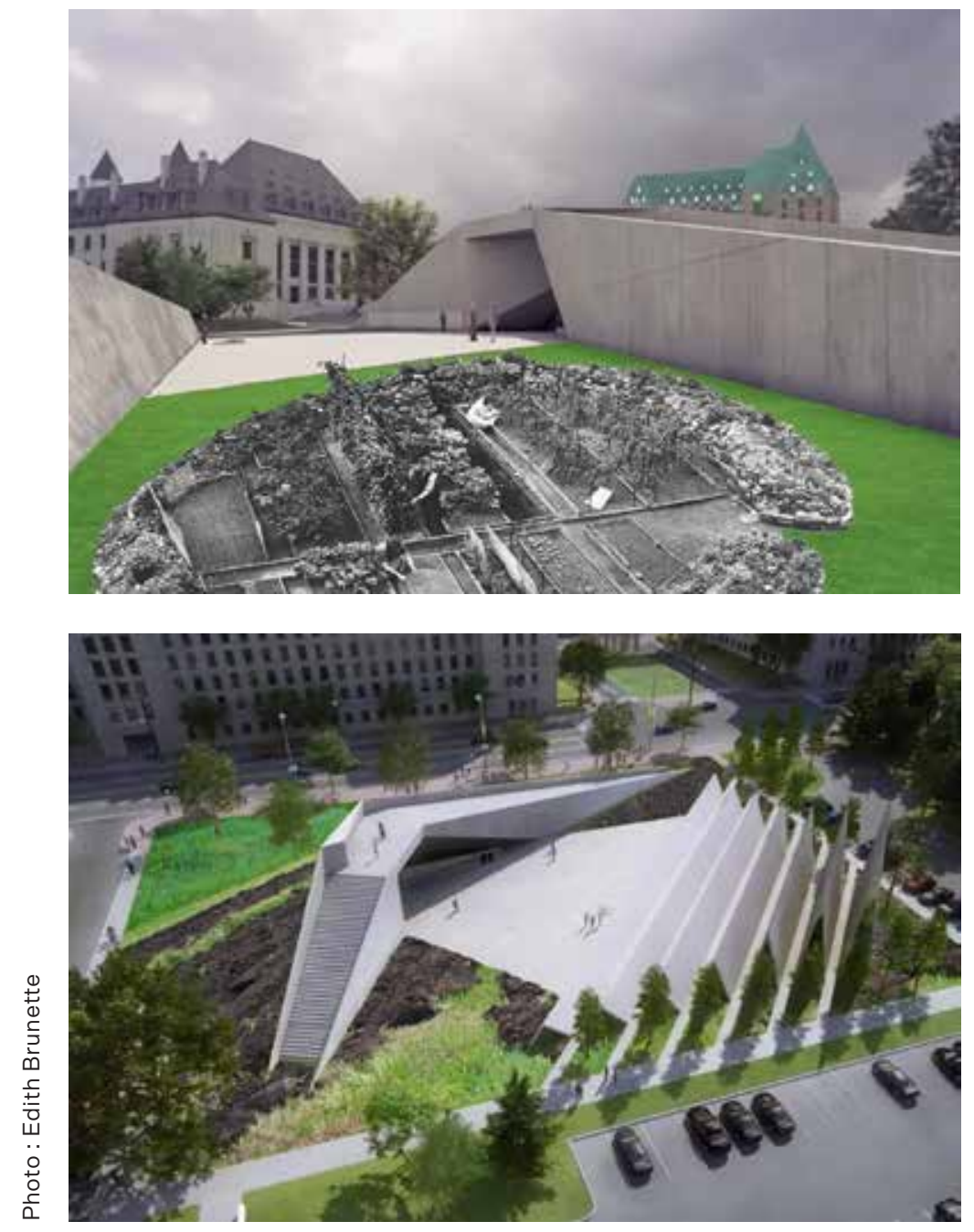



$$
\begin{aligned}
& \text { Emmanuel } \\
& \text { Galland }
\end{aligned}
$$




\section{$N O(N)$ - Documents de soumission pour le concours national (C1111-130968/A), 2015}

Impression numérique, dimensions variables.

Avec l'accompagnement de René-Luc Desjardins, designer. Cette proposition pour un «NO(N) » comme figure physique (palindrome) sur le domaine public peut sembler anachronique. Un message négatif, le non est souvent assimilé à une réaction radicale, un refus, une obstruction définitive, une fermeture à l'autre, etc. Le refus proposé par ce projet est plutôt du côté de la réaction épidermique face à une injustice. $\mathrm{Ce}$ « $\mathrm{NO}(\mathrm{N})$ » représente le signe d'une manifestation permanente de ceux qui peuvent prendre le pavé pour s'exprimer autant que pour ceux que l'on appelle les «sansvoix». Le "NO(N) » en mouvement collectif peut renverser le statu quo / la vapeur.
Digital print, variable dimensions.

With assistance from the designer René-Luc Desjardins. This proposal for a "NO(N)" as a physical figure in public space may seem to be an anachronism. A negative message, the 'no' is often associated with a radical reaction, a refusal, a definitive obstruction, a closing off to the other, etc. The refusal proposed by this project is rather that of a visceral reaction in the face of an injustice. This "NO(N)" represents the permanent demonstration of those who can take to the streets to protest as well as of the people "without a voice." The "NO(N)" as a collective movement to overthrow the status quo and turn the tide. 


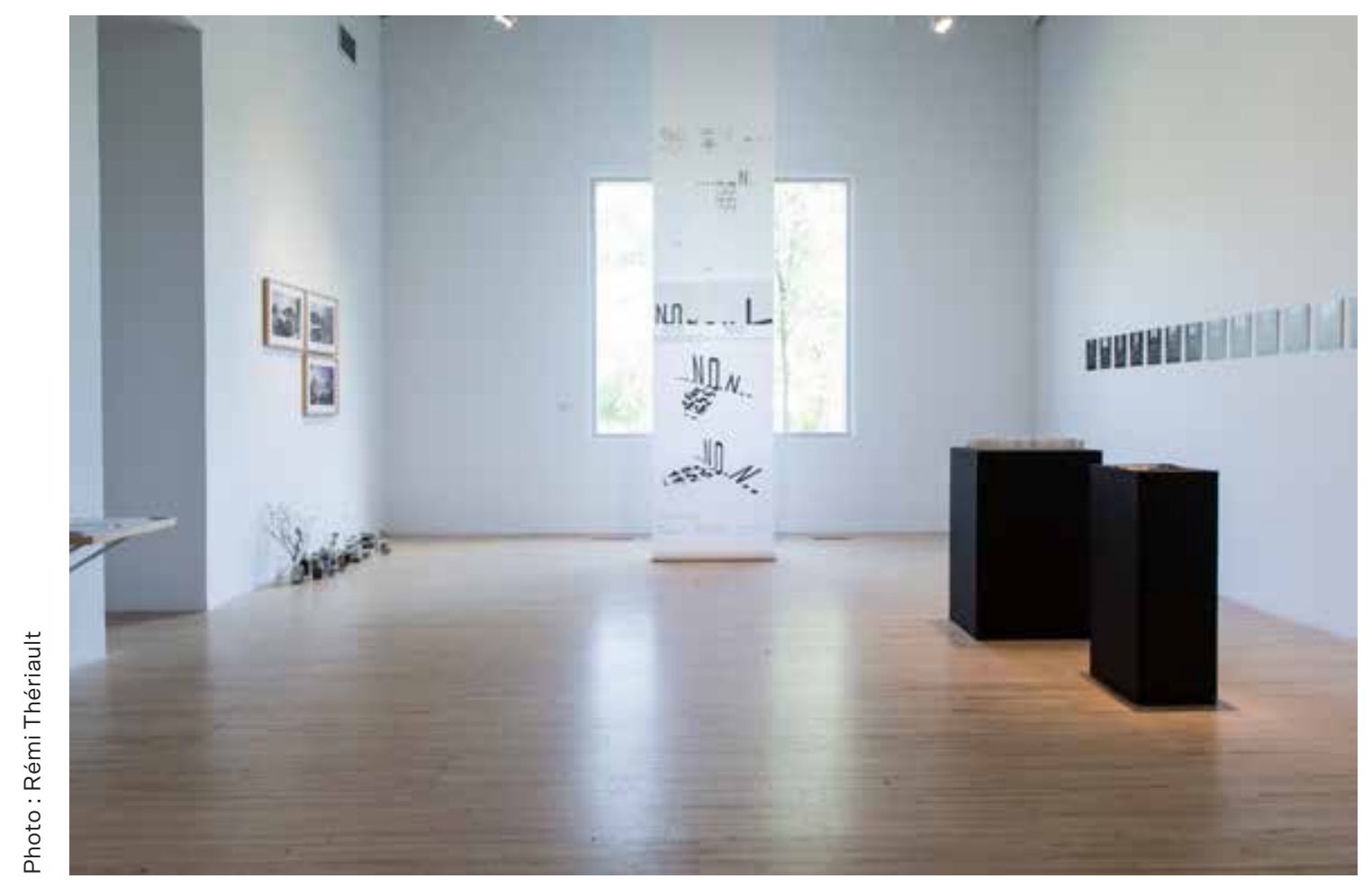




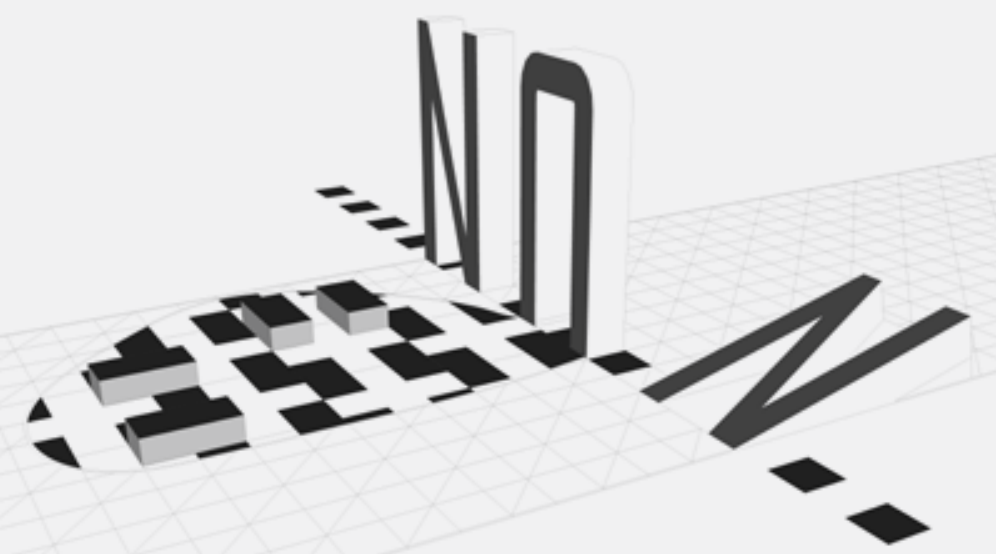




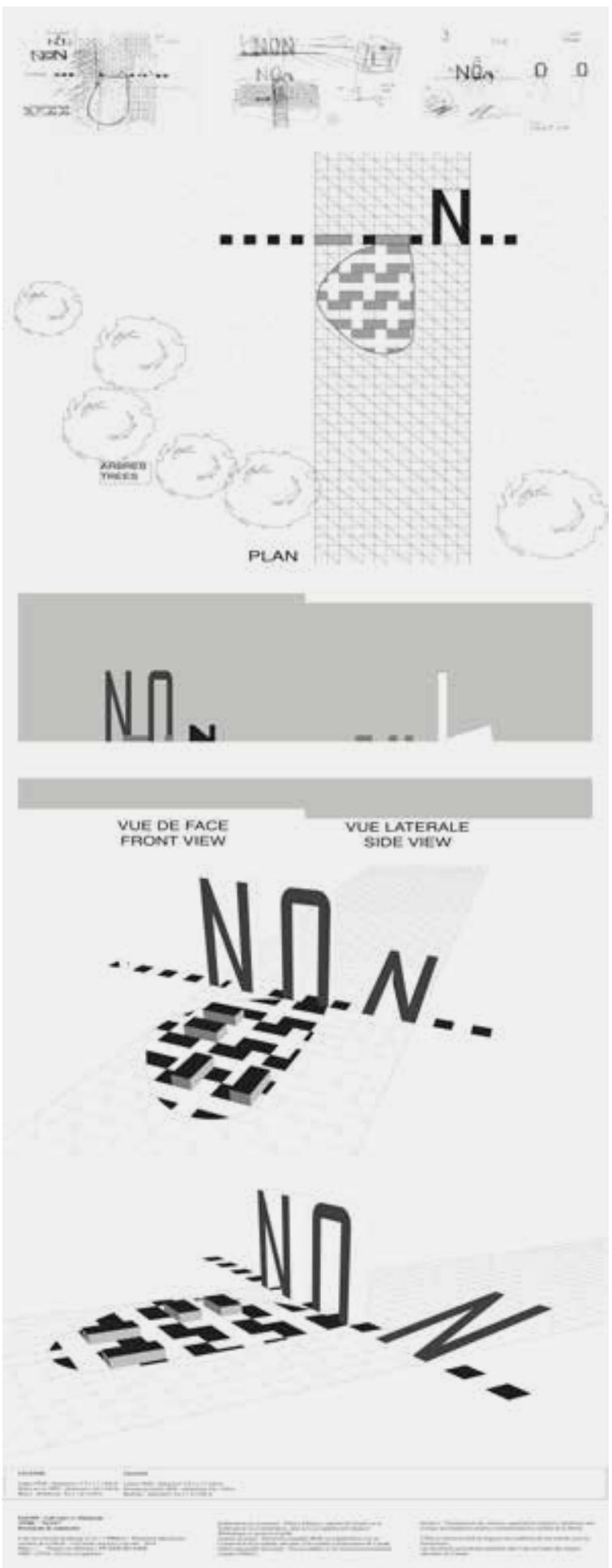





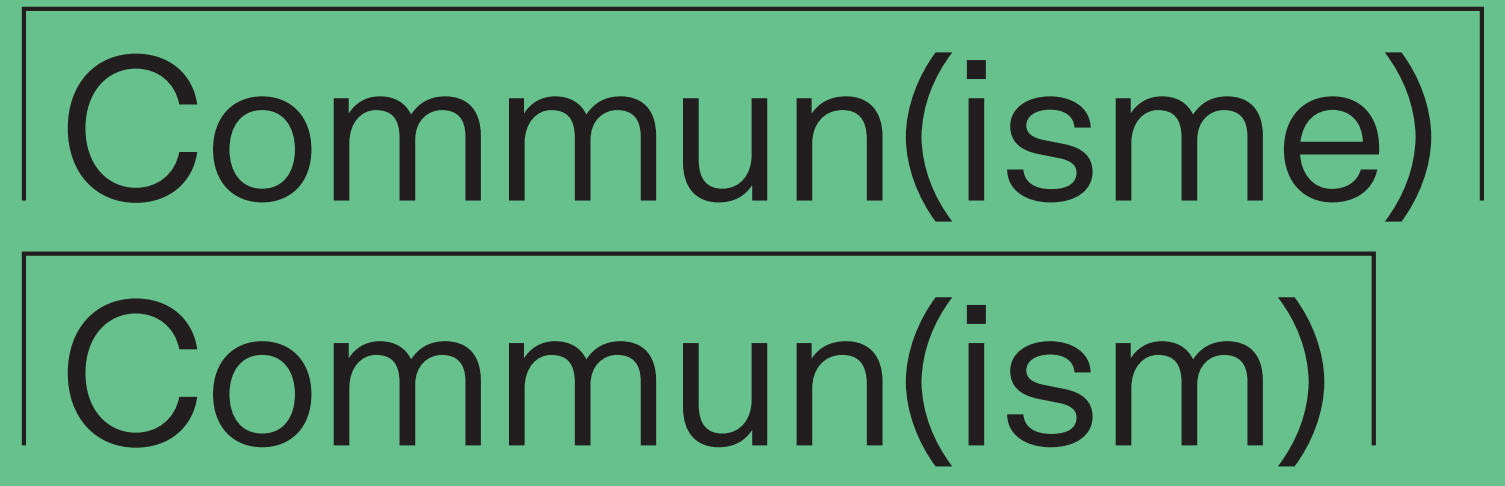





\section{Prises et entre-prises}


The problem with the French is that they don't have a word for entrepreneur.

George W. Bush

à Tony Blair 
En réponse au projet de construction d'un Monument aux victimes du communisme sur la colline parlementaire à Ottawa, le collectif Entrepreneurs du commun a voulu ouvrir un espace de réflexion afin de renouer avec les puissances qui animent notre être-en-commun. Le commun peut être défini de nombreuses manières. De façon générale et minimale, disons qu'il désigne quelque chose qui résiste aux captures et aux appropriations par des intérêts privés. Pourquoi dès lors choisir d'intégrer le mot potentiellement polémique et chargé d'opprobre "entrepreneur» dans le nom même de notre collectif? Dans le cadre de cet article, j'aimerais ouvrir une fenêtre sur le processus collectif qui a mené à ce nom. Entre raisons politico-philosophiques et notre goût pour les paradoxes qui favorisent des pratiques politico-artistiques et des modes d'engagement novateurs, cette présentation de quelques éléments de pensée animant notre collectif est l'occasion de poursuivre notre réflexion sur la condition à la fois troublante et complexe de l'artiste comme entrepreneur de soi ${ }^{43}$.

Un monde commun résiduel Nos vies se présentent de plus en plus comme des trajectoires de valorisation sur-individualisées. Nous sommes constamment amenés à nous concevoir tout un chacun comme des entrepreneurs de soi, c'est-à-dire des petits gestionnaires de notre capital social, biologique et culturel, en compétition les uns avec les autres. Nous sommes d'ailleurs confrontés au paradoxe du sémiocapitalisme. Ce système économique, qui opère en prise directe sur nos affects, nos désirs et nos penchants pour en faire des éléments de valorisation et de production, tend à dissoudre les liens communautaires alors même qu'il tire sa puissance des captures qu'il réalise sur les processus relationnels.

Si le néolibéralisme est aussi difficile à contenir, c'est en partie parce qu'il se mêle à une promesse d'intensification existentielle. Les artistes, bien sûr, n'échappent pas à cet impératif, au contraire. L'écrivain Jacob Wren, ethnographe incisif du nouvel esprit du capitalisme et de la condition artistico-politique de notre époque, décrit les tourments de la subjectivité ironico-libérale et déterritorialisée dont la vie entière se configure en termes de seuils, de modulations et de lignes d'intensification. Dès les premières lignes de Polyamorous Love Song (Bookthug, 2014), il définit l'artiste non 
pas comme un individu d'exception qui se démarque de ses contemporains par son authenticité, sa créativité ou sa capacité d'expression, mais plus prosaïquement comme celui ou celle qui se montre davantage disposé à tirer profit des élans et délires émanant de l'inconscient. Wren propose une figure littéraire des plus pénétrantes pour caractériser notre situation subjective néolibéralisée en mettant en scène une communauté d'artistes initiés à une forme nouvelle et radicale de cinéma consistant (simplement) à concevoir sa vie comme un film. La conscience de soi devient ainsi l'équivalent de la pellicule, et chacun devient le plus minutieux spectateur de soi-même dans un rapport infernal d'auto-intensification artistique. On comprendra sans peine que le livre devait à l'origine s'intituler Artists are self-absorbed. Wren s'octroie une liberté inédite pour explorer les nombreuses facettes du paradoxe que résume la célèbre formule de Robert Filliou : "L'art est ce qui rend la vie plus intéressante que l'art ». II traduit le scepticisme d'une époque-d'une culture? d'un empire?-apparemment plus encline à disséquer la mécanique du narcissisme qui propulse ses entrepreneurs de soi qu'à s'élancer dans une aventure politique collective aux contours, il faut le dire, souvent incertains.

Le néolibéralisme nous plonge dans un rapport certes intense au monde, mais à terme appauvri et destructeur. C'est un constat finalement assez banal que chacun éprouve de multiples façons, et pourtant il n'est pas toujours facile de nommer et de faire fond sur cette évidence sensible. Le commun est en deuil, le commun est en reste : il apparaît comme quelque chose de résiduel, de marginal et de menacé. Encore faut-il s'en persuader et se montrer collectivement à la hauteur de ce qui fait l'objet d'une offensive concertée, d'une guerre ouvertement déclarée.

Voilà sans doute pourquoi nous nous sommes d'abord assez spontanément appelés Les orphelins du commun. Ce nom était cependant trop mélancolique et trop défensif; il insistait davantage sur la disparition et la perte de l'en-commun que sur de possibles mises à l'aventure collectives. II nous fallait quelque chose de plus entraînant, de plus offensif. Nous avons donc décidé de l'abandonner.

Nous croyions avoir enfin trouvé lorsque nous avons envisagé nous appeler Les spectres de la liberté. La référence à Marx nous faisait sourire, et puis 
l'appellation convenait bien à notre désir de hanter le projet du gouvernement Harper. Mais certains d'entre nous trouvaient le nom un peu fade, ou glauque, ou geek et auto-référentiel, c'est selon. En tous les cas, on voit déjà combien l'acte de dénomination collectif était pris au sérieux-enjeu "corporatif", enjeu d'incorporation. Nous voulions un nom qui accroche et qui soit aussi fédérateur que possible. Se nommer, c'est, pourrait-on se risquer à dire, introduire dans le fonctionnement du collectif une abstraction esthétiquement appropriée. Aussi paradoxal que cela puisse paraître de prime abord, il en est de même de la manière dont nous instaurons une dimension collective d'anonymat. II ne s'agit pas ici d'une pratique ascétique ou privative de l'anonymat, qui impliquerait un effacement de chacun pour la cause commune, mais plutôt de la recherche d'une configuration symbolique favorisant l'expression de la dimension transformatrice et transindividuelle de notre expérience collective. En ce sens, comme le souligne avec justesse Geert Lovink :

" [T] o dismantle the performance of the self and self-disclosure is to revisit anonymity in today's context. The question is how to re-imagine anonymity not as an attainable categorical state, but as a way to recoup an energy of metamorphosis, the desire to become someone else ${ }^{44}$."

Mais pour oser se revendiquer du beau mot d'entrepreneur, il aura encore fallu autre chose, une impulsion dite néo-monadologique que j'aimerais à présent esquisser.

Le commun en possession Le commun n'existe qu'en relation, d'où sa dimension intrinsèquement plurielle et écologique; d'où le faire-monde qui s'attache à sa suite. Étymologiquement, le commun désigne à la fois un être-ensemble (com-) et une charge partagée, une obligation (munus). Cette obligation est à entendre au sens littéral comme ce qui nous lie, en paroles et en actes.

Il y a plusieurs manières de relever le défi d'une pensée et d'une pratique du commun qui anime et mette à l'aventure. Souvent, les politiques communistes tablent sur une commune dépossession. C'est le cas, par exemple, des groupes qui se rallient au cri de Omnia sunt communia, qui résonne ces derniers temps avec une ardeur renouvelée ${ }^{45}$. On peut aussi défendre la dimension commune de l'existence en se refusant au jeu des évaluations. 
Par exemple, le laisser-être, ou le Gelassenheit heideggérien, est à la source de plusieurs variations contemporaines autour des notions de démobilisation et de désœuvrement. Allant à l'encontre de l'isomorphisme culturel d'un monde livré corps et âme à la (dé)mesure du capital, il en appelle à la prolifération des mondes et à une éthique de la proximité, au plus loin de toute abstraction programmée.

Mais arrive-t-on jamais à mettre nos existences, nos amours, nos amitiés et tout ce à quoi nous tenons à l'abri du processus général d'abstraction de la valeur? Et inversement : en refusant d'emblée tout processus de valorisation, ne coure-t-on pas le risque de produire une idée du commun tellement éloignée des conditions actuelles d'existence (c.-à-d. néolibérales) qu'elle en vienne à n'être plus qu'un fantasme protecteur, qu'il soit conservateur ou progressiste? Y a-t-il d'autres façons de penser le rapport entre résistance, commun sensible et abstraction sans faire le jeu du capital?

L'approche cosmopolitique proposée par Isabelle Stengers et Bruno Latour pose elle aussi la question du commun, cependant elle l'envisage de façon radicalement différente, les auteurs se tournant vers une conception positive des valeurs et des processus d'abstraction inspirée par les travaux du philosophe et mathématicien Alfred N. Whitehead. Isabelle Stengers est prompte à dénoncer le principe de l'équivalence généralisée au nom du caractère hétérogène et incommensurable des pratiques. Son concept d'écologie des pratiques et sa pensée cosmopolitique mettent l'accent sur le problème de la fabrication d'une coexistence pacifique entre des mondes tenus pour essentiellement multiples et divergents. On retrouve un même souci chez Bruno Latour : "Le monde commun est à composer ", dit-il dans son Manifeste compositionniste, ce qui signifie en premier lieu « qu'on peut rater sa composition ${ }^{46}$ ".

Alors que la pensée post-heideggérienne aborde le commun sur fond d'une grammaire de l'être et de l'événement, la pensée de l'écologie des pratiques développée par Stengers et Latour s'appuie de son côté sur une philosophie des possessions ${ }^{47}$. II ne faut pas se laisser abuser par le caractère apparemment conservateur de la question de la possession. Paradoxalement, c'est en s'y penchant qu'on peut espérer battre en brèche l'individu-propriétaire, en restant au plus près du caractère fluctuant de ce qu'un individu dit « sien ». 
À la fin de sa communication au colloque Les gestes spéculatifs à Cerisy-laSalle, en juillet 2013, Stengers a introduit une image de pensée qui illustre avec à-propos l'inflexion néo-monadologique caractérisant Entrepreneurs du commun. Avec une provocante simplicité, elle a décrit les Grecs comme le «peuple des entrepreneurs». Avec ce mot, entre-preneur, elle cherchait à faire entendre le jeu des prises enchevêtrées qui mettent à l'aventure et la "morsure d'un possible» qui insiste en chacune de ces prises. Mais n'est-ce pas une décision périlleuse et terriblement partiale que de mettre la philosophie sous le signe de l'entreprise? N'y perd-on pas quelque chose comme un accès inconditionnel à "l'être "? L'image du peuple des entrepreneurs diffère profondément de celle à laquelle nous sommes plus habitués, constituée d'un groupe de sages barbus et désœuvrés contemplant la perfection sphérique de l'être, pour reprendre la scène primitive de la philosophie telle que fabulée par Peter Sloterdijk dans Globes.

II y a dans cette conception de l'entreprise commune quelque chose d'à la fois humble et stimulant. Humble, parce qu'elle incite à prêter davantage attention à la singularité de chacune des prises qui nous constituent, de chacune des initiatives qui participent de la composition collective. Cette conception est en outre stimulante, dans la mesure où elle nous protège des bons sentiments souvent associés à la protection de la chose commune en laissant libre cours à l'invention de formes d'être-ensemble non fusionnelles et à géométrie variable - des collectifs disjonctifs, pour reprendre l'expression de Peter Pal Pelbart. En faisant jouer l'entre des prises et en insistant sur les possibles qui peuplent ces interstices, l'appellation Entrepreneurs du commun offre finalement une posture d'énonciation collective inédite, en prise sur la condition néolibérale qui nous est faite. Tout se passe en somme comme si, grâce à cette appellation, il devenait soudainement possible de nommer, pour soi-même et pour autrui, «les puissances impersonnelles, physiques et mentales que l'on affronte et que l'on combat, dès que l'on essaie d'atteindre un but $[\ldots]^{48}$ ». 

The problem with the French is that they don't have a word for entrepreneur.

George W. Bush

to Tony Blair 
In response to the project of building a Memorial to the Victims of Communism on Parliament Hill in Ottawa, the Entrepreneurs du commun (Entrepreneurs of the commons) sought to open a space of reflection to revive the forces of our being-in-common. The commons can be defined in many ways. In a general and minimal sense, it designates something that resists the captures and appropriations of private interests. Why then did we incorporate this potentially polemical and much excoriated word "entrepreneur" into the name of the collective? With this article, I would like to provide a glimpse into the collective process that led to this choice of name. Framed both by politico-philosophical reasons and an avowed weakness for paradoxes that favour novel politico-artistic practices and modes of engagement, this presentation of the essentials at the heart of the collective is an occasion to broaden our perspective on the both troubling and complex condition of the artist as an entrepreneur of the self. ${ }^{43}$

A Residual World of the Commons Our lives are increasingly becoming trajectories of over-individualized valuation. We are constantly led to think of ourselves as entrepreneurs of the self, i.e. as little managers of our social, biological and cultural capital, who compete with one another. We are, moreover, faced with the paradox of semiocapitalism. This economic system, which seizes upon our affects, desires and propensities to turn them into elements of valuation and production, undoes community links even while drawing its power from the captures it makes of relational processes.

If it is so hard to contain neoliberalism, it is partially because it partakes in a promise of existential intensification. Artists, of course, do not escape this imperative, quite on the contrary. The writer Jacob Wren, an incisive ethnographer of the new spirit of capitalism and the artistico-political condition of our era, described the torments of our ironic-liberal and deterritorialized subjectivity whose entire life is configured in terms of thresholds, modulations and lines of intensification. In Polyamorous Love Song (Bookthug, 2014), he defines the artist not as an exceptional individual whose authenticity, creativity and expressive capacity distinguishes him or her from his or her contemporaries, but more prosaically as someone who proves him or herself to be more apt to take advantage of the impulses and deliriums emerging from the unconscious. Wren proposes a penetrating 
literary figure to describe our subjective neoliberal situation by displaying a community of artists who are being initiated to a new and radical form of cinema consisting (simply) of conceiving one's life as a film. Self awareness thus becomes the equivalent of an exposed film and everyone thus acts as a meticulous observer of him or herself in an infernal relationship of artistic self-intensification. One clearly understands why the book was first to have been called Artists are Self-absorbed. Wren takes an extraordinary liberty in exploring the many facets of the paradox that is summed up by Robert Filliou's famous expression: "Art is what makes life more interesting than art." It translates the scepticism of an era-of culture? of an empire?-apparently more inclined to dissect the mechanisms of the narcissism that drives these entrepreneurs of the self than to set out on a collective political adventure with, it must be said, often uncertain outlines.

Neoliberalism immerses us in a relationship with the world that is certainly intense, but ultimately impoverished and destructive. It is finally a rather banal observation that everyone experiences in various ways, and yet it is not always easy to name or build on this palpable fact. The commons are in mourning and left out: it appears to be something residual, marginal and threatened. Yet, we must collectively live up to that which is the object of a coordinated attack, an openly declared war.

That is perhaps why we at first spontaneously called ourselves The Orphans of the Commons. This name was, however, too melancholic and defensive; it put more of an emphasis on the disappearance and loss of an in-common than on possible collective adventures. We needed something more engaging and offense oriented. We thus decided to abandon it.

We finally thought we had found something when we contemplated calling ourselves the Spectres of Liberty. The reference to Marx made us smile, and the title resonated with our wish to haunt the Harper government's project. But some of us found the name a little dull, or gloomy, or geeky and self-referential, it depends. In any case, one already gets a sense of how seriously the action of naming the collective was being taken-a "corporative" issue, an issue of incorporation. We wanted a catchy name that would have a unifying effect. To name oneself is, one could dare say, 
to introduce an aesthetically appropriate abstraction into the collective's functioning. Though it may at first seem paradoxical, this is the same way that a collective dimension of anonymity is established. It is not about an ascetic or depriving practice of anonymity, which would spell an erasure of each for the common cause, but rather about the search for a symbolic configuration fostering an expression of the transformative and transindividual dimension of our collective experience. It is in this sense that Geert Loving aptly highlights that:

[T] o dismantle the performance of the self and self-disclosure is to revisit anonymity in today's context. The question is how to re-imagine anonymity not as an attainable categorical state, but as a way to recoup an energy of metamorphosis, the desire to become someone else. ${ }^{44}$

But to dare to claim the worthy designation of entrepreneur, there must have been, among other things, a neo-monadological drive that I would now like to outline.

Inter-holding the Commons The commons exists only in relation, whence its intrinsically plural and ecological dimension; whence the world-making quality that comes with its continuation. Etymologically, the commons designates both a being-together (com) and a shared responsibility, an obligation (munus). This obligation is understood in the literal sense as something that binds us in word and deed.

There are several ways of meeting the challenge of a theorizing and practice of the commons that stimulates action and adventure. Communist politics often count on a common dispossession. For instance, this is the case for groups that rally around the Omnia sunt communia slogan that has been resonating lately with a renewed vigour..$^{45}$ One can also defend the common dimension of existence by refusing to participate in the game of evaluations. For example, letting-be, or Heideggerian Gelassenheit, is the source of several contemporary variations around the notions of demobilization and inoperability. Going against the grain of the cultural isomorphism of a world that is entirely at the mercy of capital's measure and excess, it calls for a proliferation of worlds and an ethic of proximity, far removed from any programmed abstraction. 
But can one ever shelter our existences, loves, friendships and everything we care for from the general process of value's abstraction? And inversely: in immediately refusing any valorization process, does one not run the risk of producing an idea of the commons that is so far removed from current conditions of existence (i.e. neoliberal ones) that it becomes nothing more than a protective phantasy, regardless whether it be conservative or progressive? Are there other ways of conceiving the link between resistance, the common sensible and the power of abstractions without playing into the hands of capital?

The cosmopolitical approach proposed by Isabelle Stengers and Bruno Latour also raises the question of the commons, however they conceive of it in a radically different way. They turn to a positive conception of the values and processes of abstraction inspired by the work of the philosopher and mathematician Alfred N. Whitehead. Isabelle Stengers, following Felix Guattari, denounces the principle of general equivalence in the name of the practices' heterogeneous and incommensurable character. Her concept of an ecology of practices and her cosmopolitical proposal highlight the problem of constructing a pacifist coexistence between worlds that are essentially held to be multiple and divergent. Bruno Latour shares the same concern: "The world of the commons is to be composed," he says in his Manifeste compositionniste, which firstly means that "one can mess up one's composition." 46

While post-heideggerian thought approaches the commons on the basis of a grammar of being and the event, the reflection about the ecology of practices developed by Stengers and Latour is for its part based on a philosophy of possessions..$^{47}$ One must not be misled by the apparently conservative character of possession. Paradoxically, it is by examining it that one can hope to demolish the notion of the individual-owner, i.e. by remaining very close to the fluctuating character of what an individual says to be his or her own. At the end of her presentation at Les gestes spéculatifs symposium in Cerisy-la-Salle, in July 2013, Stengers introduced a thought-image that fittingly illustrates the neo-monadological inflection that characterizes Entrepreneurs du commun. With a provocative simplicity, she described 
the Greeks as the "people of entrepreneurs." With this word, entre-preneur (inter-holders), she sought to foreground the play of entangled "prises" (holds or grips) that stimulate adventure and the "intimation of a possibility" that pressingly inhere in each of these grips. But is it not a risky and partial decision to place philosophy under the sign of an enterprise? The image of the people of entrepreneurs greatly differs from the one we are more accustomed to, for it consists of a group of bearded and idle wise men who contemplate the spherical perfection of being, to relay the primal scene of philosophy that Sloterdijk dreamed up in Globes.

There is something both humble and stimulating about this conception of the entre-prise, of this undertaking of the commons. Humble, because it encourages us to pay more attention to the singularity of each prise (hold) we are constituted by, of each the initiatives contribute to the collective composition. In giving free rein to the invention of non co-dependent and variable forms of being-together-disjunctive collectives, to borrow Peter Pal Pelbart's expression-this conception is also stimulating, in so far as it protects one from the well-meaning sentiments often associated with the protection of the commons. In giving free play to the empty space animating the inter-holdings (l'entre des prises) and insisting on the possibilities that inhabit these interstices, Entrepreneurs du commun's designation ultimately offered an original collective enunciation that can get a hold on the neoliberal condition that we have been dealt. Everything happens as if, thanks to this designation, it suddenly became possible to identify, for oneself and others, "the impersonal, physical and mental forces that one confronts when engaging in any form of struggle in an attempt to reach a goal ... ." 48 

Steve

Giasson 


\section{snowwhitelenin, 2010}

Vidéo couleur, sonore, 3 min $40 \mathrm{~s}$.

La vidéo snowwhitelenin résulte de la superposition d'un reportage sur le père de la révolution russe de 1917, Vladimir Ilitch Lénine, et d'un extrait du long métrage Blanche-Neige, de Disney. Remerciements : Martin Vinette, Robert Fitterman.
Color and sound video montage, $3 \mathrm{~min} 40 \mathrm{~s}$

In snowwhitelenin, a report on the head of the 1917 Russian Revolution Vladimir llyich Lenin and an excerpt from Disney's feature film Snow White are superimposed. Thanks: Martin Vinette, Robert Fitterman. 


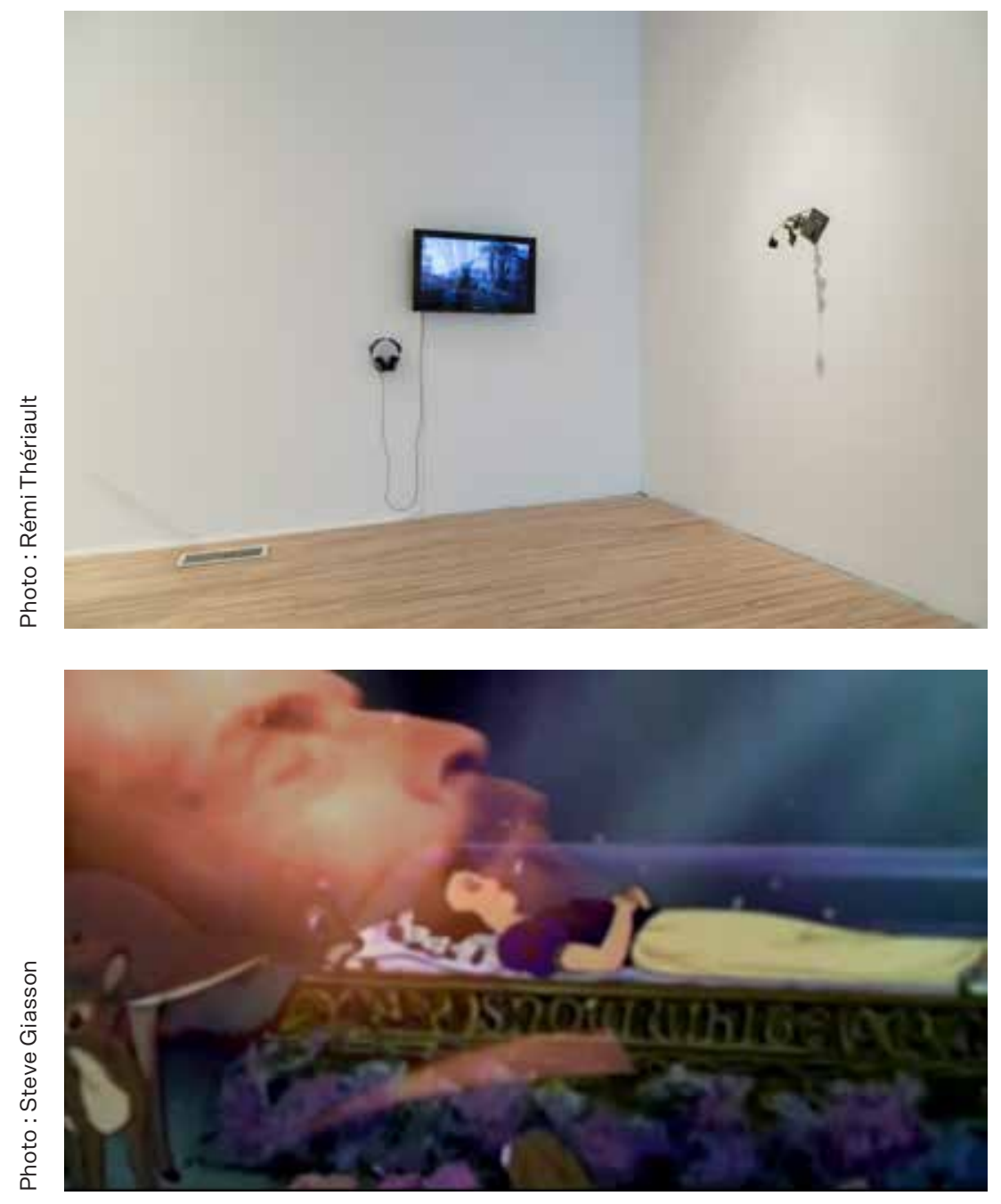




\section{L'homme d'acier, 2015}

Plaque commémorative en acier et en aluminium, rose, $14,4 \times 11,5 \mathrm{~cm}$.

Cette plaque commémorative, qui date d'avant la chute du rideau de fer, montre Staline de profil. Elle a été retirée d'un édifice public en Bulgarie et mise en vente sur le site d'enchères eBay pour la somme de 28,99 \$ US. Elle est fixée au mur à l'aide d'une rose rouge véritable en référence à la peinture Roses for Stalin (1949), de Boris Eremeevich Vladimirski.
Commemorative plaque in steel and aluminum, rose, $14.4 \times 11.5 \mathrm{~cm}$.

This plaque, which dates from before the fall of the iron curtain, shows the profile of Stalin. It was taken down from a public building in Bulgaria and then sold on the auction site ebay for US\$28.99. Here, it is fixed to the wall with a real red rose, in reference to painting Roses for Stalin (1949) by Boris Eremeevich Vladimirsky. 


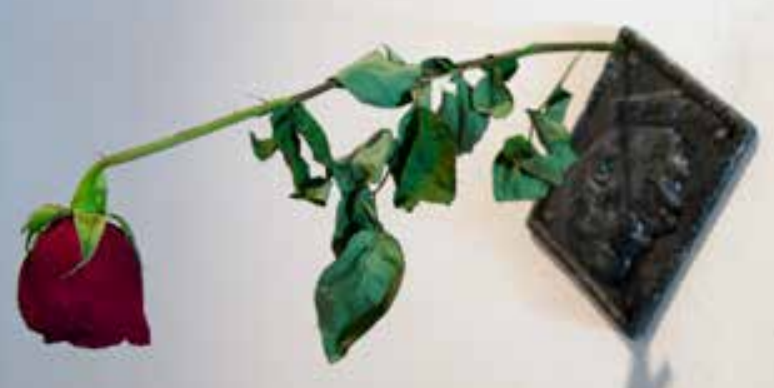

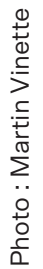




\section{Spectres, 2015}

Manifestes du Parti communiste de Karl Marx et de Friedrich Engels, sacs de plastique Walmart, dimensions variables.

Les onze éditions du Manifeste du Parti communiste vendues par Walmart sont ici exposées. Elles ont récemment été achetées sur le site Web du géant américain de la vente au détail.
Manifestos of the Communist Party of Karl Marx and Friedrich Engels, plastic bags Walmart, variable dimensions.

The eleven editions of the Communist Manifesto sold by Walmart are exhibited here. They were recently purchased on the website of this giant US retailer. 


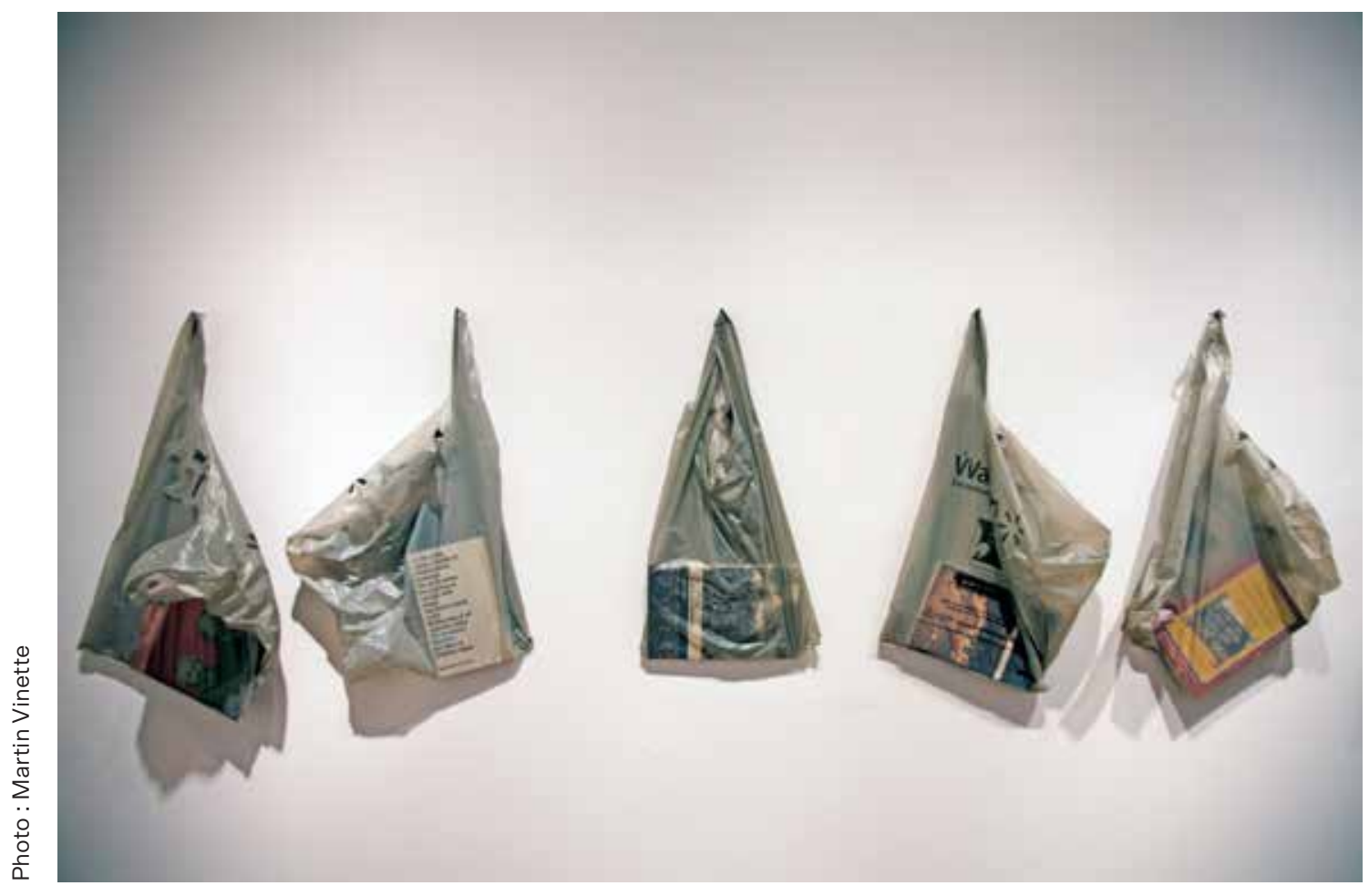



Nicolas

Rivard 


\section{Curriculum vitæ d'un gouvernement du désastre, 2015}

Impressions sur papier, $213 \times 91,4 \mathrm{~cm}$, $30 \times 35,6 \mathrm{~cm}$. (chaque cadre)

Graphisme : Jasmin Cormier

Remerciements : Josée Desforges

Dans le cadre de ce projet, les actions entreprises par le gouvernement Harper susceptibles d'entraver les droits et libertés durant ses années au pouvoir (2006-2015) ont été recensées. Elles sont présentées sous la forme d'un curriculum vitæ constitué de neuf sections détaillant la nature de ces entraves, soit sociale, politique, juridique, culturelle et patrimoniale, environnementale, scientifique, médiatique, économique et militaire. Le logo apposé sur le curriculum vitæ est dérivé de celui de la Fabrique culturelle, une initiative de Télé-Québec qui fait la promotion des arts dans les diverses régions du Québec. Sont également exposés trois documents qui prennent la forme de lettres de motivation. Accompagnées du curriculum vitae, ces lettres ont été envoyées au gouvernement.
Paper print, $213 \times 91.4 \mathrm{~cm}$, $30 \times 35.6 \mathrm{~cm}$. (each frame) Graphics: Jasmin Cormier Acknowledgement: Josée Desforges

This project surveys the actions undertaken by the Harper government, which has been prone to impede people's rights and freedoms since it came to power in 2008. These actions are presented in the form of a resumé consisting of nine sections that provide information on the nature of their obstructions: social, political, legal, cultural, environmental, scientific, media, economic and militarial. The logo on the resumé detourns the logo of Fabrique culturelle, a TéléQuébec initiative promoting the arts in various regions of Quebec. The three documents addressed to the government take the form of cover letters, and were sent, together with the curriculum vitae, to their destination. 


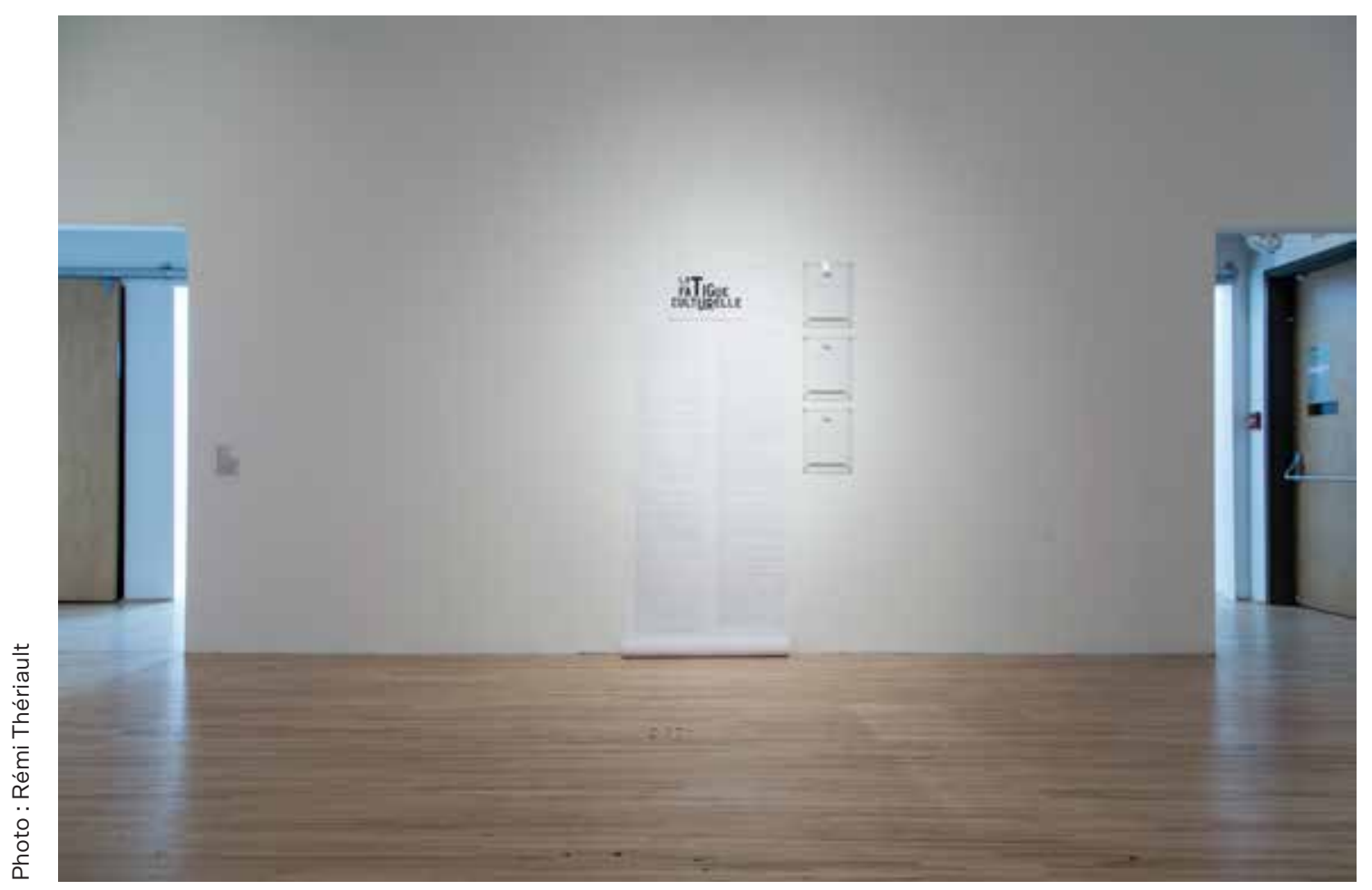




\section{LAT IGUE
CULTURELLE}

CURRICULUM VITAE D'UN GOUVERNEMENT DU DESASTRE
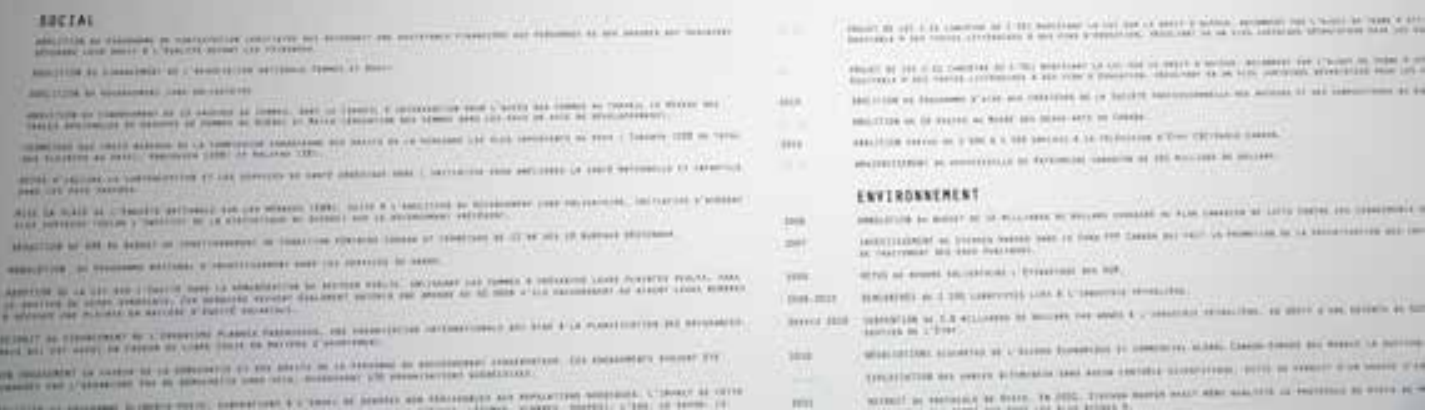


\section{. FAT IGUE CULTURELLE}

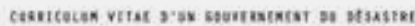
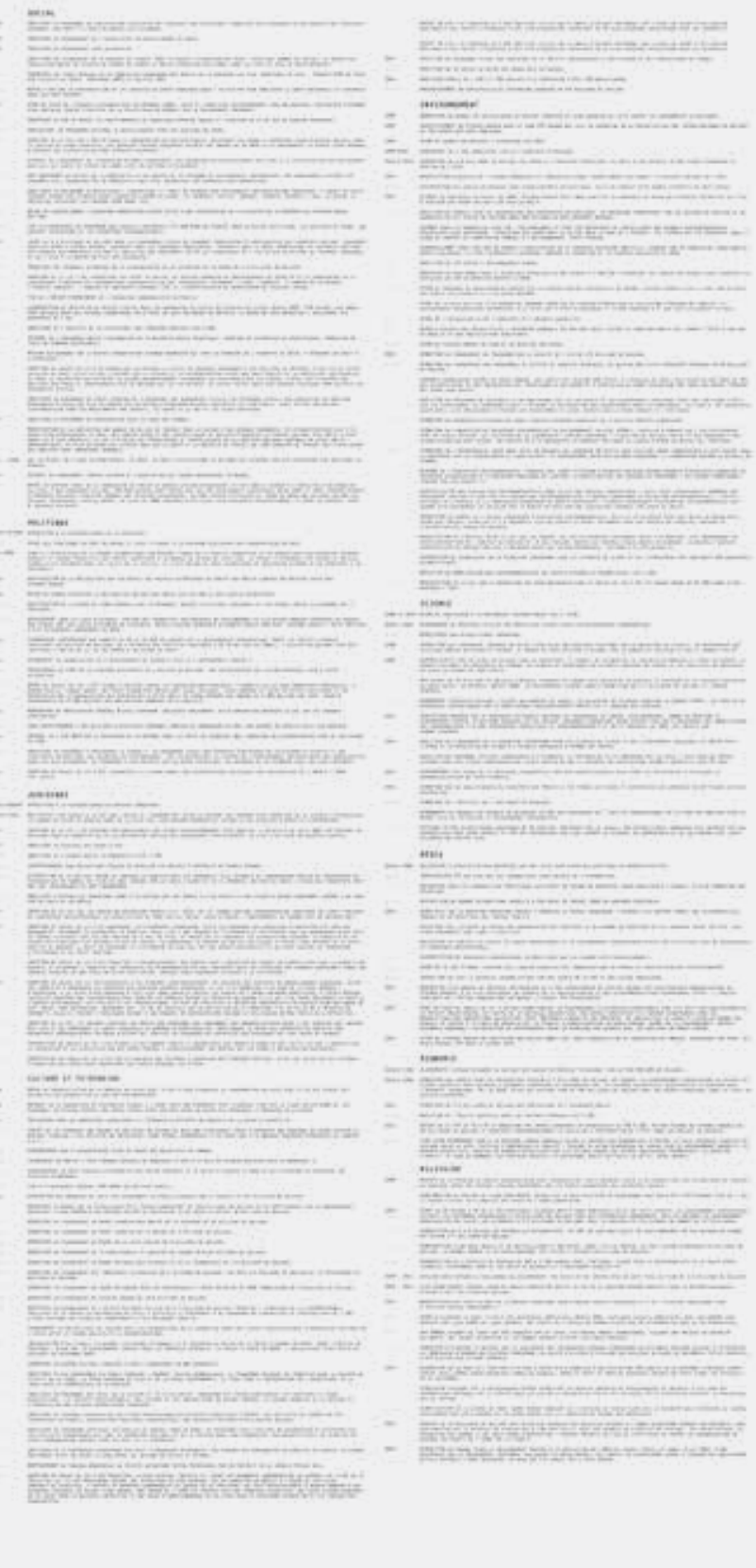

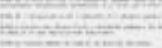

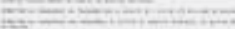

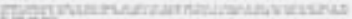

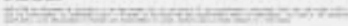
सr:

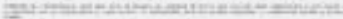

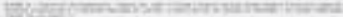

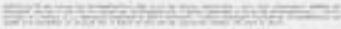
Prifuthe:

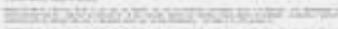

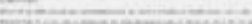
nis:

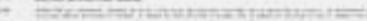

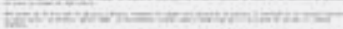
N =

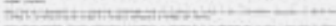

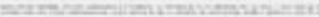
=

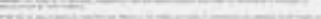

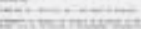

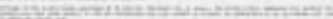
min -rwan-

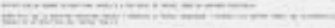

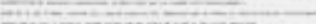

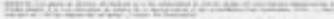

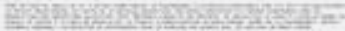
स्थल:

$\because 0$

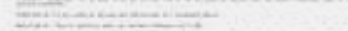

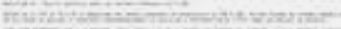

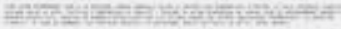
nimi

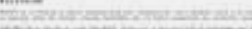

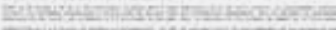
7\%

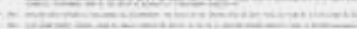
-

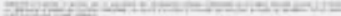

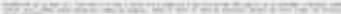
-

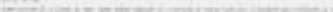

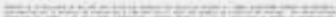

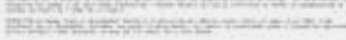





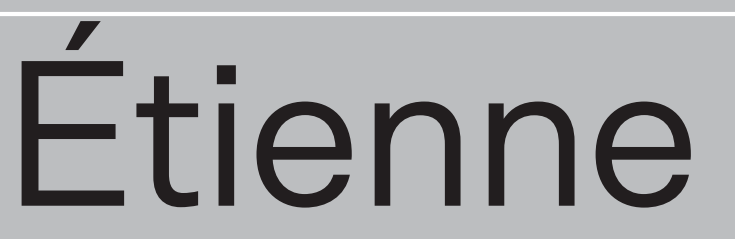

Tremblay-

Tardif 


\section{Separation of Capital and State, 2015}

Bande audio diffusée dans les salles d'eau, 60 min. en boucle. Cartes d'affaires distribuées dans les salles d'eau, 250 exemplaires.

Hommage à la liberté est le nom de l'association privée qui est à l'origine du projet de Monument aux victimes du communisme. Étienne Tremblay-Tardif s'est intéressé au réseau d'influence tissé par cette association avec différentes instances du pouvoir économico-politique (gens d'affaires, Sénat canadien, parlementaires élus, institutions publiques, clubs sociaux, etc.). Son œuvre sonore associe les récits de vie des membres d'Hommage à la liberté à des discours de personnages publics et à des passages de l'œuvre du philosophe Maurizio Lazzarato. Les extraits sélectionnés portent un regard critique sur les idées de liberté et de libéralisme.

Des cartes d'affaires créées à partir de documents promotionnels d'Hommage à la liberté ont également été distribuées dans les espaces d'AXENÉO7 afin de solliciter des dons. Remerciements : Adriana Disman.
Audio tape transmitted in the bathroom, $60 \mathrm{~min}$. loop. Business cards, 250 copies.

Tribute to Liberty is the name of the private organization that is behind the proposed Memorial to the Victims of Communism. Étienne Tremblay-Tardif was interested in the network of influences in terms of economic and political power that this organization brought together (business people, Canadian Senate, elected parliamentarians, public institutions, social clubs, etc.). His audio work connects the biographies of the members of Tribute to Liberty to the speeches of public figures and to excerpts from the work of the philosopher Maurizio Lazzarato. These selections take a critical look at the ideas of freedom and liberalism.

Business cards, upon which donations are solicited, are also distributed among the spaces of the AXENÉO7 gallery. They were created from promotional material for the Tribute to Liberty. Acknowledgement: Adriana Disman. 


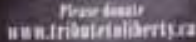
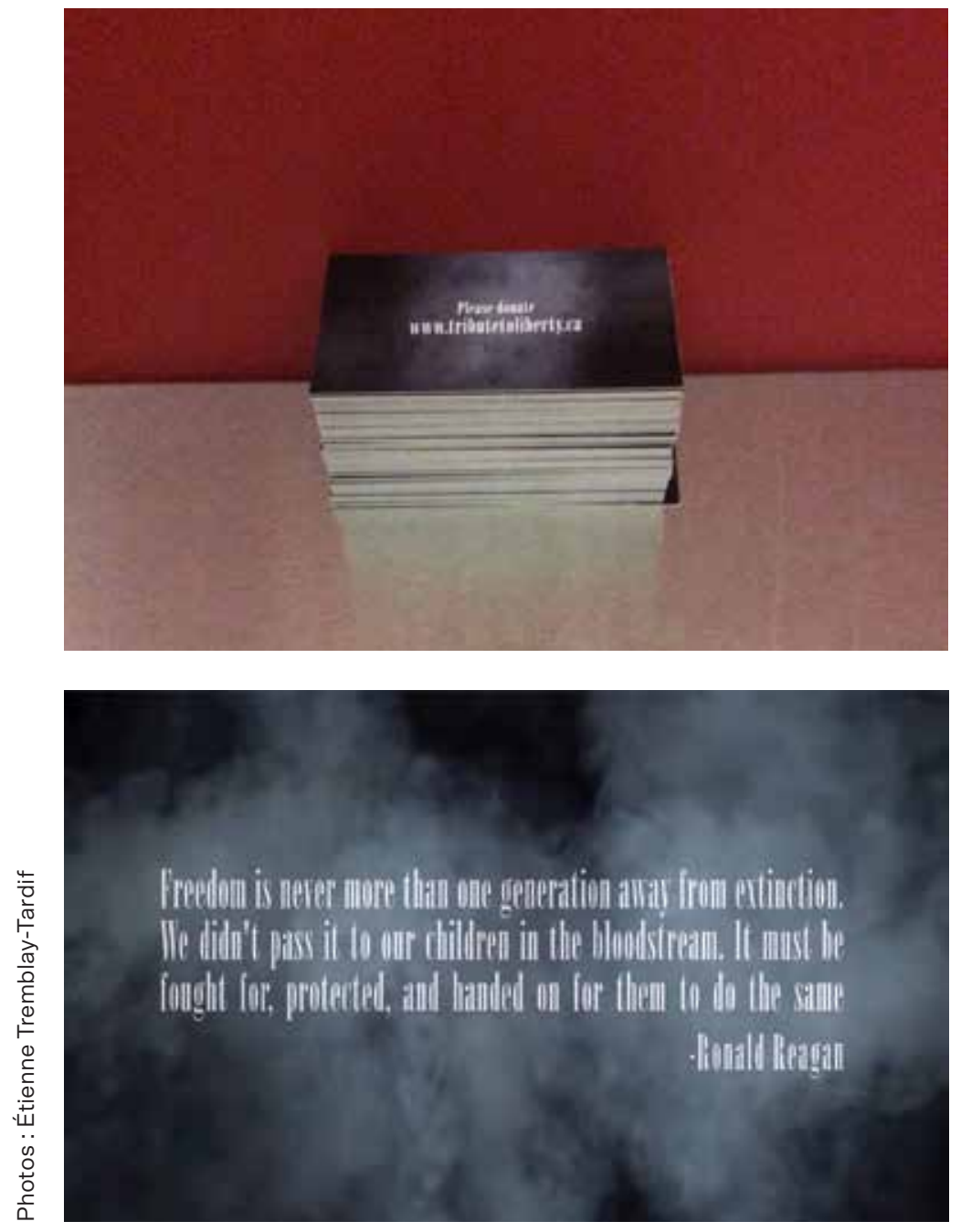


\section{Transcription audio}


53:00

[applaudissements]

[basses fréquences en écho]

[voix féminine] :

"The liberal managers of the crisis have not hesitated to include a 'maximum state' among the apparatuses of governmentality but a state that now exercises its sovereignty uniquely on the population. To free up the markets, liberal management imprisons society, intervening in heavy-handed, invasive, and authoritarian ways in the life of the population in an effort to govern all aspects of behaviour. If, like every form of liberalism, it produces the 'freedoms' of owners (of capital securities), it reserves for non-owners a mere semblance of what is already weak 'political' and 'social' democracy." [martèlement métallique en arrière-plan]

[mélodie jouée au piano reprise en sourdine]

[basses fréquences en écho]

[voix de Stephen Harper] :

"...under our Government, Canada has cut support for terrorists led governments. We have condemned human rights abuses and, ladies and gentlemen, Canada proudly, resolutely, unequivocally stands with the people of Ukraine. Now..." [applaudissements]

"I was told that, I just want to add something, I was told that a couple of weeks ago Mister Putin made some comments, saying he didn't understand why Harper and Canada cared so much about Ukraine. It's a long way away, he says.

[intensification des basses fréquences en écho]

The fact that he doesn't get it tells you there's a problem. Freedom, democracy, justice; that's what it's all about for the people of Ukraine.

[applaudissements]

A couple of months ago I traveled to Ukraine as some of you know. The first G7 leader to do so. During my visit I had the pleasure meeting with Prime Minister Yatsenyuk, and shared, and when we met, I shared with him, as I continue to share with my counterparts in the G7 and beyond, that what is happening today to the millions in Ukraine is both a wake up call and a call to actions. Over the last several months, indeed years, the world has watched as President Putin has grown more comfortable with confrontation. His boldness had increased since Russian troops have made an open grab for power in Crimea. The impact of the Putin Regime's expansionism and militarism extends beyond Ukraine. It threatens the security of our Eastern European allies and by extension the stability and security of the world. Now friends, I cannot predict what this next months or years hold for Ukraine, for Europe, for Canada. But I do know this: Canadians have always supported freedom and democracy for all people and we will not hold back that support now, from the people of Ukraine." [ajout d'une fréquence au bruit ambiant]

[voix féminine] :

"Laws do not define 'forms of general intervention excluding particular, individual, and exceptional measures.' On the contrary, laws are prescriptive; they do not only determine a formal framework, set the 'rules of the game,' but prioritize certain contents-and in minute detail. They impose the flexibility required of the job market, define a tax system favourable to rents, cut pensions, social spending, etc. The 'freedom' that remains to 'agents' is the freedom to carry out orders."

[arrêt soudain du grondement en arrière-plan]

[reprise des basses fréquences en écho]

[bruits de frottements et de glissements]

[clic de souris]

[voix de synthèse] :

"In September 2009 Tribute to Liberty, received approval from the National Capital Commission (NCC) to build a Memorial to the Victims of Communism-Canada, A Land of Refuge on National Capital Region land."

$57: 20$ 



$$
\begin{aligned}
& \text { Anne-Marie } \\
& \text { Trépanier } \\
& \text { Alexandre } \\
& \text { Piral }
\end{aligned}
$$




\section{excellentes.solutions, 2015}

Site Web présenté sur tablette, campagne d'affichage extérieur

Anne-Marie Trépanier et Alexandre Piral présentent le site Web collaboratif excellentes.solutions qui propose aux usagers de participer à l'édification d'un «monument à écrire», que ce soit en galerie ou dans leur foyer. Ce site souhaite construire « un bloc de texte et d'images en mouvement constant, brouillon d'une mémoire collective incontrôlable». Les artistes ont également mené une campagne d'affichage à Gatineau et à Ottawa qui, tout en détournant les codes des campagnes électorales, permet au public de prendre connaissance de leurs activités.
Website featured on tablet, outdoor postering campaign

Anne-Marie Trépanier and Alexandre Piral present the collaborative website excellentes.solutions. They invite users of the site to interact in the gallery or at home in order to contribute to the construction of a "monument to be written." This website aims to erect "a block of text and images in constant motion, a draft of an uncontrollable collective memory." In Gatineau and Ottawa, the artists also carried out an outdoor postering action appropriating the codes of electoral campaigns to raise public awareness of their activities. 


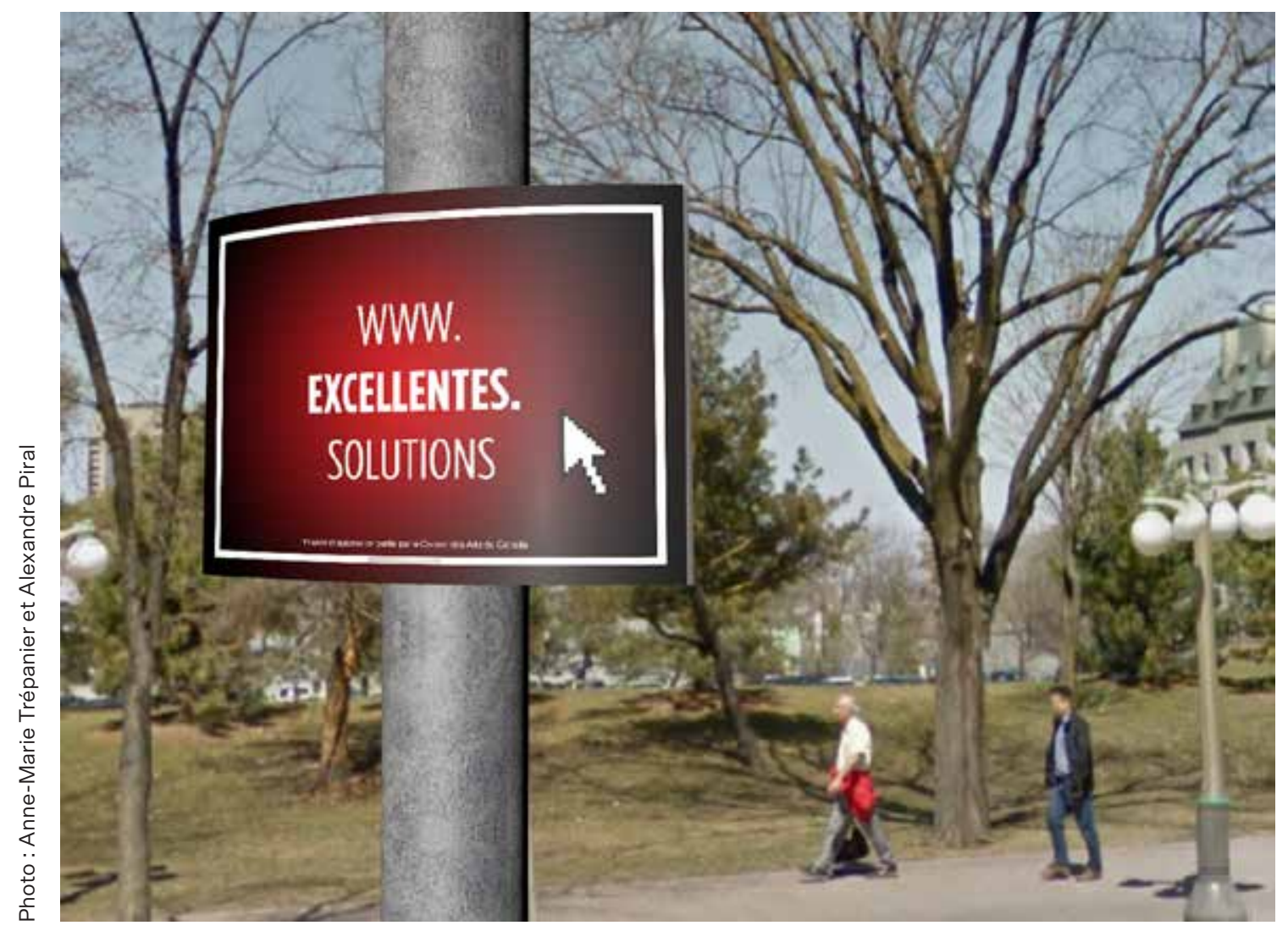



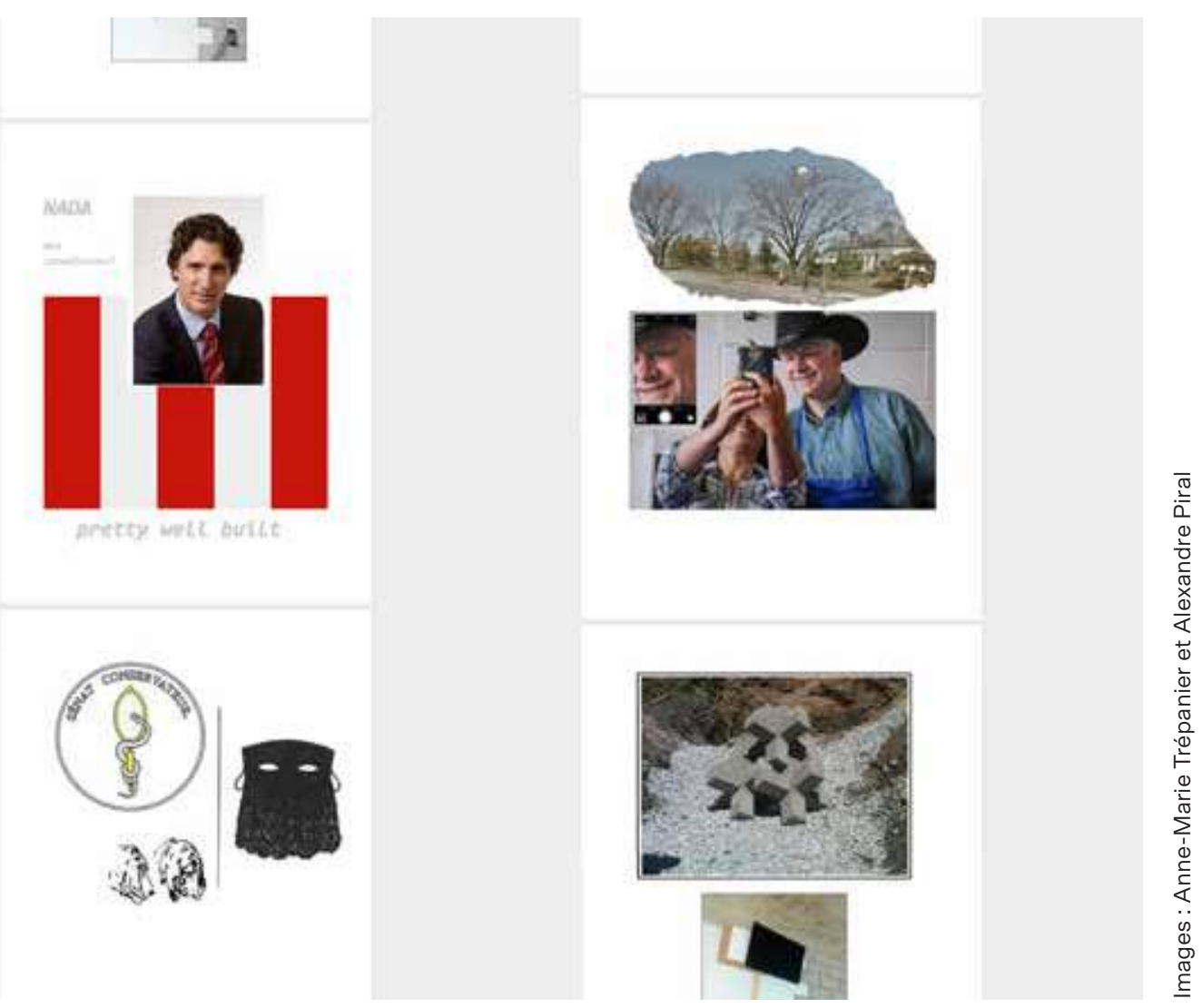
Thierry

Marceau 


\section{John Wayne Gacy, Hi Ho With Clown, 1989}




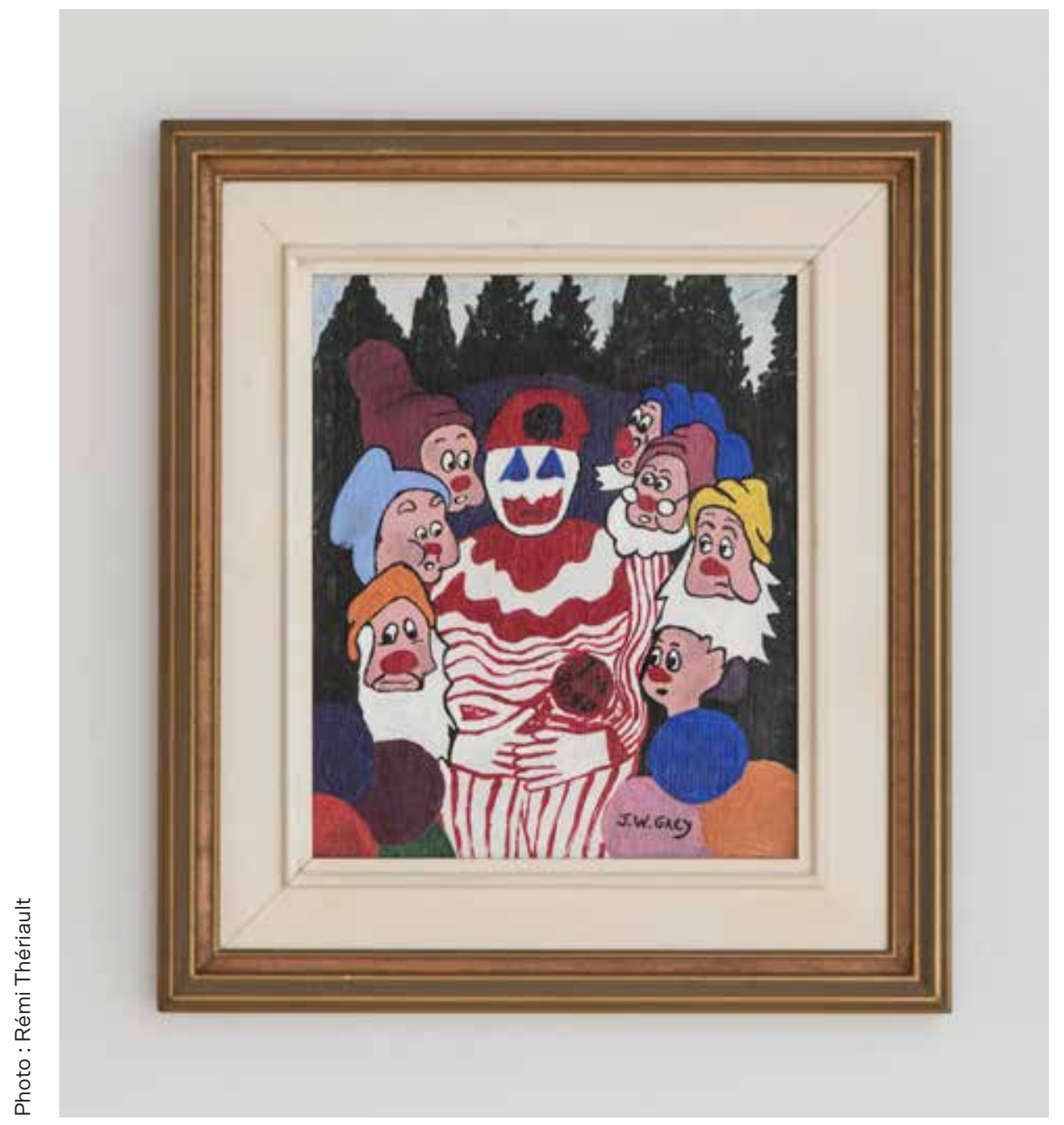




\section{Pogo et les 7 nains: résidence de production de 14 ans en vue de la vente aux enchères, 2015.}

Vidéo couleur, sonore, $8 \mathrm{~min}$.

Pogo est un personnage créé par John Wayne Gacy pour ses apparitions à des collectes de fonds, à des parades et à des fêtes d'enfants. Aussi connu sous le nom de Killer Clown (clown tueur), John Wayne Gacy est en réalité un tueur en série américain qui a été reconnu coupable du viol et du meurtre de 33 adolescents et jeunes hommes, commis entre 1972 et 1978 à Chicago, dans I'lllinois. II a passé 14 ans en prison avant d'être exécuté par injection létale le 10 mai 1994, au Centre correctionnel Stateville. En 2002, il est entré dans le Livre Guinness des records comme la personne condamnée à la plus lourde peine jamais imposée, soit 21 condamnations à perpétuité et 12 condamnations à mort.

De 1980 à 1994, alors qu'il attendait son exécution, Gacy peignait dans sa cellule. Ses tableaux maladroits ont été achetés par des collectionneurs, et des marchands d'art lui ont même passé des commandes afin de satisfaire à la demande.

Dans les mois suivant l'exécution, plusieurs toiles de Gacy ont été mises aux enchères. Dix-neuf ont été vendues par le collectionneur Stephen Koschal, qui les avait commandées personnellement à Gacy. La peinture représentant les 7 nains de Disney jouant au baseball contre les Cubs de Chicago a obtenu la plus haute mise. Elle avait été autographiée par plusieurs membres du Temple de la renommée du baseball, qui ignoraient l'identité du peintre.

En réponse au Monument aux victimes du communisme, Thierry Marceau examine ici le modèle alternatif qui est célébré. II met en lumière une facette de ce modèle, le capitalisme, où des individus sont prêts à débourser de fortes sommes pour posséder l'œuvre d'un meurtrier. En se mettant dans la peau de John Wayne Gacy, il se prête à un jeu qui n'est pas sans rappeler les conditions de production des artistes en art actuel. Il apparait perché dans une cage, se donnant en spectacle à un public qui n'y est pas, avec peu de moyens, de latitude et d'attention, et beaucoup de répétitions... Thierry Marceau propose Pogo en guise de monument glorifiant la bêtise humaine, qu'elle soit communiste, capitaliste, socialiste, communautariste ou encore artistique. 
Colour video, sound, 8 min.

"Pogo" is a character created by John Wayne Gacy for his appearances at fundraisers, in parades, and for children's parties. Also known as the "Killer Clown," John Wayne Gacy was indeed an American serial killer. He was found guilty for acts of sexual assault and the murder of 33 adolescents and young men, all committed between 1972 and 1978 in Chicago, Illinois. He spent 14 years in prison before being executed by lethal injection on May 10, 1994 at Stateville Correctional Centre. In 2002, he was added to the Guinness Book of Records as the individual who received the longest sentence at trial: 21 life sentences and 12 death sentences. From 1980 to 1994, while awaiting his execution, Gacy painted in his cell. His clumsy paintings were purchased by collectors, and while he was still alive were even commissioned by art dealers to satisfy demand.

In the months following his execution, several of Gacy's paintings were auctioned. Nineteen were sold by the collector Stephen Koschal, who had personally ordered them from Gacy. A painting of Disney's Seven Dwarfs playing baseball against the Chicago Cubs got the highest bid. This painting had been autographed by many members of the Baseball Hall of Fame without the signatories being informed of the painter's identity.

In response to the Memorial to the Victims of Communism, Thierry Marceau here questions the alternative model that the monument champions. It highlights a facet of this model, capitalism, where individuals pay large sums of money to possess the work of a murderer. Putting himself in the shoes of John Wayne Gacy, Thierry Marceau follows the rules of a game that is reminiscent of the conditions under which contemporary artists work. Thierry Marceau offers "Pogo" as a monument glorifying human stupidity, whether communist, capitalist, socialist, communitarian or, even, artistic. 


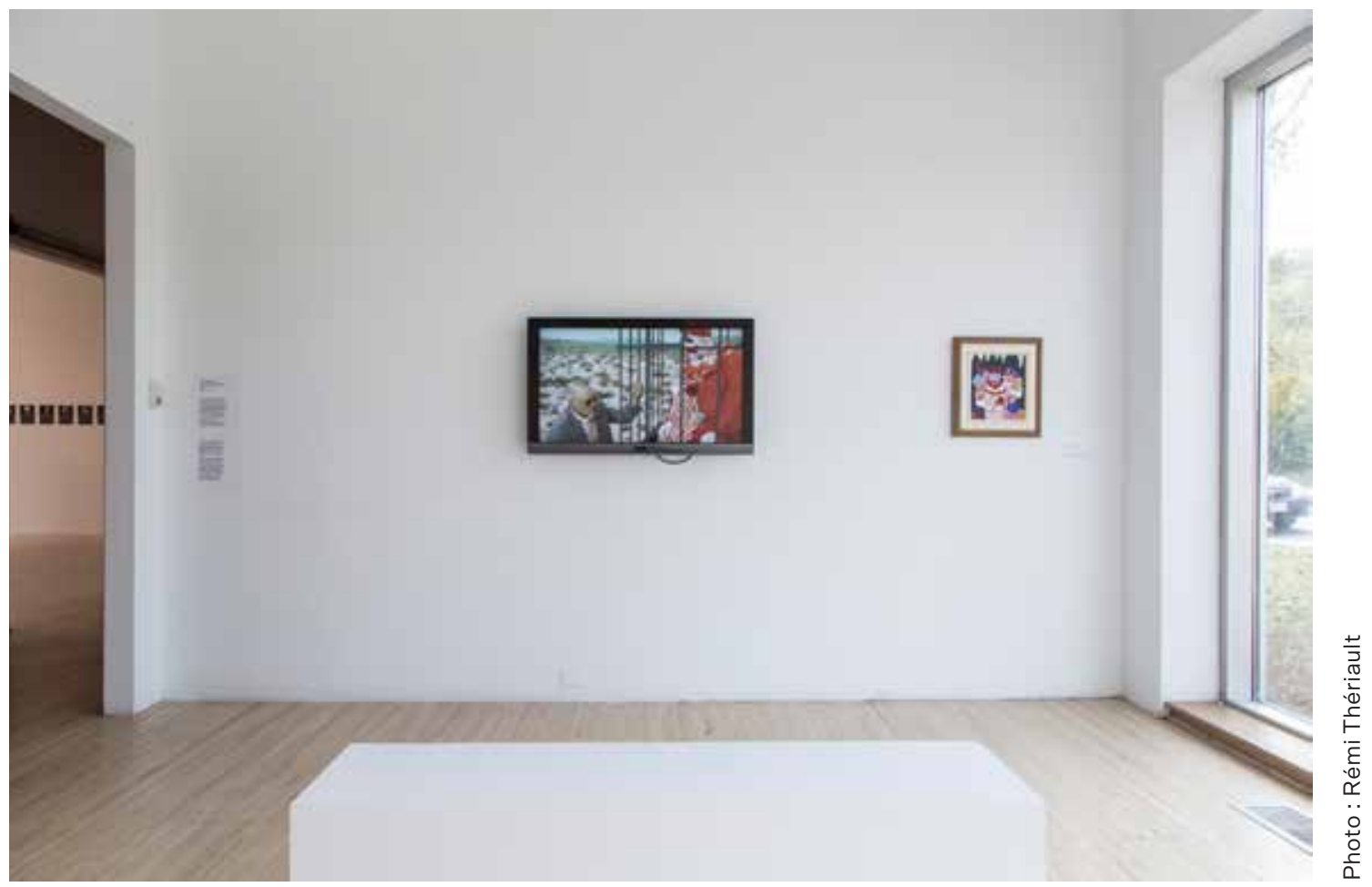



Notes 
1 Hommage à la Liberté, «Why a Memorial? Why in Canada?», http://tributetoliberty.ca/ $\mathrm{fr} /$ memorial-why (consulté le 19 janvier 2018).

2 Eliza Mackintosh, «Hungarian camerawoman sentenced for kicking, tripping refugees ", CNN, 13 janvier 2017, www.cnn.com/2017/01/13/europe/hungariancamerawoman-sentenced-kicking-refugees/ index.html (consulté le 19 janvier 2018).

3 Shelly Glover, ministre du Patrimoine canadien, communiqué de presse, «Monument commémoratif national aux victimes du communisme-Le Canada, une terre d'accueil », 18 août 2014.

4 Steve Hendrix, "Poland wants to outlaw blaming Poles for Nazi atrocities. But what about the Jedwabne massacre?", Washington Post, 6 février 2017.

5 Ceci dit, seul le Parti conservateur était en faveur de son installation en face de la Cour suprême.

6 Le programme des activités est disponible sur le site http://entrepreneursducommun.net/.

7 Voir en particulier la longue série d'articles de Don Butler publiés dans le quotidien Ottawa Citizen en 2014 et 2015.
8 Voir l'analyse d'un corpus de plus de 2000 mentions Web présentée dans l'article suivant: Nathalie Casemajor, Sylvain Rocheleau, Rosa Iris Rovira Rodriguez, Philippe Lachaine, Khaoula Zoghlami, «The Figure of the Cascade in the Study of Online Public Debate Trajectories: A Transplatform Study » (à paraître).

9 L'exposition devait initialement durer une semaine. Elle s'est ajoutée à une programmation déjà établie, grâce à l'appui d'AXENÉO7.

10 À ce nombre, se sont ajoutées plus tard les contributions de Michel de Broin et de Frank Shebageget.

11 Alain Badiou, «Le socialisme est-il le réel dont le communisme est l'idée?", dans Alain Badiou et Slavoj Zizek (dirs.), L'idée du communisme. Volume 2. Conférence de Berlin 2010, Paris, Nouvelles Éditions Lignes, 2011, p. 9-22.

12 Jacques Rancière, Figures de l'histoire, Paris, PUF, 2012, p. 58.

13 L'enregistrement vidéo de la journée de colloque est disponible en ligne à l'adresse suivante: www.entrepreneursducommun.net.

14 Pour plus de détails, voir le texte de Dalie Giroux dans le présent ouvrage.

15 Pour un aperçu du projet initial et des événements ayant mené à son remplacement, voir : https://en.wikipedia.org/wiki/Memorial_ to_the_Victims_of_Communism_\%E2\%80\%93_ Canada,_a_Land_of_Refuge (consulté le 12 novembre 2017).

16 Pour un résumé éclairant des polémiques entourant les statues historiques publiques aux États-Unis et des contre-stratégies déployées par le milieu artistique, voir Gregory Sholette, «Reimagining Monuments to Make Them Resonate Locally and Personally », hyperallergic.com, 6 novembre 2017.

17 Juha Siltala, «National Rebirth out of Young Blood ", Scandinavian Journal of History, vol. 31, nos 3-4, 2006, p. 299. 
18 Nestor Garcia-Canclini, Cultures hybrides. Stratégies pour entrer et sortir de la modernité, traduit de l'espagnol par Francine Bertrand Gonzalez, Québec, Presses de l'Université Laval, 2010, p. 215.

19 Tonya Davidson, « Mica, Pedagogy, and Defacement: Learning from Canada's National War Memorial », The Public Historian, vol. 38, $n^{\circ} 2$, mai 2016, p. 42-61.

20 Chris Cobb, «War Memorial guard program is designed for dignity ", Ottawa Citizen, 22 octobre 2014, p. A6.

21 Giorgio Agamben, Profanations, traduit de l'italien par Martin Rueff, Paris, Éditions Payot \& Rivages, 2005, p. 97.

22 Pour plus de détails, veuillez consulter la page suivante : http://carleton.ca/fass/2016/profaneperambulations-a-public-humanitiesexperiment-in-the-parliamentary-precinct/.

23 George Grant, Technology and Empire, Toronto, House of Anansi, 1969, p. 17.

24 Cet essai s'inspire de critiques du contremonument que j'ai déjà émises dans «Points of No Return: Cultural Heritage and CounterMemory in Post-Yugoslavia ", dans Erica Lehrer, Cynthia Milton et Monica Eileen Patterson (dirs.), Curating Difficult Knowledge: Violent Pasts in Public Places, New York, Palgrave Macmillan, 2011; et dans «In Ruins: Architecture, Memory, Countermemory ", Journal of the Society of Architectural Historians, vol. 73, n 4, 2014.

25 James E. Young, At Memory's Edge: AfterImages of the Holocaust in Contemporary Art and Architecture, New Haven, Yale University Press, 2002, p. 96.

26 Pierre Nora (dir.), Les Lieux de mémoire, Paris, Gallimard, 1984-1992.
27 Pierre Nora, «Entre mémoire et histoire. La problématique des lieux ", dans Pierre Nora (dir.), Les lieux de mémoire, vol. 1, Paris, Gallimard, 1984, p. XIX- XX.

28 Pierre Nora, «General Introduction: Between Memory and History ", dans Pierre Nora (dir.), Realms of Memory: Rethinking the French Past, vol. 1, New York, Columbia University Press, 1996, p. 1

29 James E. Young, The Texture of Memory: Holocaust Memorials and Meaning, New Haven, Yale University Press, 1993, p. 5.

30 James E. Young, op. cit., 2002, p. 118.

31 Ibid., p. 96.

32 Ibid., p. 92.

33 Ibid., p. 119.

34 Pour en savoir plus sur la post-politique, voir notamment Jacques Rancière, «Introducing Disagreement ", Angelaki: Journal of the Theoretical Humanities, vol. 9, n³, 2004; et Chantal Mouffe, On the Political, Routledge, New York, 2005.

35 Voir par example Francis Fukuyama, The End of History and the Last Man, New York, Free Press, 1992.

36 Pierre Nora, op. cit., 1984, p. VIII.

37 Le travail historiographique de Nora dans Les Lieux de mémoire est donc en continuité avec ses activités post-politiques dans d'autres domaines, comme la fondation de la revue $L e$ Débat, qui sert de tribune au discours «postpartisan », et son refus de publier une traduction française de The Age of Extremes, d'Eric Hobsbawm. Sur Le Débat, voir Pierre Nora, "Que peuvent les intellectuels?», Le Débat, vol. 1, n 1, 1980, p. 1-19; sur la non-traduction de l'ouvrage de Hobsbawm, voir Pierre Nora, "Traduire : nécessité et difficultés », Le Débat, vol. 142, n 93, 1997, p. 93-95; et sur l'émergence de la post-politique en France, voir Michael Scott Christofferson, French Intellectuals Against the Left: The Antitotalitarian Moment of the 1970s, New York, Berghahn, 2004. 
38 Sur la Commune de Paris, par exemple, Marx a écrit : «La classe ouvrière n'espérait pas des miracles de la Commune. Elle n'a pas d'utopies toutes faites à introduire par décret au peuple. Elle sait que pour réaliser sa propre émancipation et avec elle cette forme de vie plus haute à laquelle tend irrésistiblement la société actuelle [...] elle aura à passer par de longues luttes, par toute une série de processus historiques, qui transformeront complètement les circonstances et les hommes. " Voir Karl Marx, La guerre civile en France, Paris, Éditions sociales, 1953, p. 46. Voir également Karl Marx, Le 18 Brumaire de Louis Bonaparte (1852), Paris, Les Éditions sociales, 1969.

39 Michel Foucault, "Il faut défendre la société ", Cours au Collège de France. 1976, Paris, Seuil/ Gallimard, 1997, p. 10.

40 Tribute to Liberty, «Why a Memorial? Why in Canada?», http://tributetoliberty.ca/memorialwhy (consulté le 12 décembre 2017).

41 Michel Foucault, "Qu'est-ce qu'un auteur?», Dits et écrits, 1954-1988. Tome 1 : 1954-1969, Paris, Gallimard, 2001, p. 808.

42 Entrepreneurs du commun, «Monuments aux victimes de la liberté », http:// entrepreneursducommun.net/?page_id=122 (consulté le 12 décembre 2017).

43 Cette question a été discutée en détail dans le cadre de la Journée sans culture, une initiative qui a (dé)mobilisé plusieurs centaines d'acteurs du milieu artistique et culturel. Certains des organisateurs de cette grève symbolique ont également participé aux activités d'Entrepreneurs du commun. Pour plus de détails, visitez le site www.journeesansculture.ca/fr/.

44 Geert Lovink, Networks Without a Cause, Cambridge, Polity Press, 2012, p. 46.

45 Voir mon article "Omnia Sunt Communia », Spirale, n²53, été 2015, p. 6-7.

46 Bruno Latour, «ll n'y a pas de monde commun : il faut le composer », Multitudes, n 45, été 2011, p. 40.

47 Pour plus de détails, voir Didier Debaise (dir.), Philosophie des possessions, Paris, Les Presses du réel, 2011.

48 Gilles Deleuze, Pourparlers, Paris, Éditions de minuit, 2003, p. 121. 
Notes 
1 Tribute to Liberty, "Why a Memorial? Why in Canada?," http://tributetoliberty.ca/en/ memorial-why (accessed on January 19, 2018).

2 Eliza Mackintosh, "Hungarian camerawoman sentenced for kicking, tripping refugees," $C N N$, January 13, 2017, www.cnn.com/2017/01/13/ europe/hungarian-camerawoman-sentencedkicking-refugees/index.html (accessed on January 19, 2018).

3 Shelly Glover, Minister of Canadian Heritage, press Release, "National Memorial To Victims of Communism-Canada Land of Refuge," August 18, 2014.

4 Steve Hendrix, "Poland wants to outlaw blaming Poles for Nazi atrocities. But what about the Jedwabne massacre?," Washington Post, February 6, 2017.

5 That being said, only the Conservative Party supported its installation in front of the Supreme Court.

6 The full program of activities is available at: http://entrepreneursducommun.net/.

7 See Don Butler's series of articles published in the Ottawa Citizen between 2014 and 2015.
8 See the analysis of 2000 Web mentions in the following article: Nathalie Casemajor, Sylvain Rocheleau, Rosa Iris Rovira Rodriguez, Philippe Lachaine, Khaoula Zoghlami, "The Figure of the Cascade in the Study of Online Public Debate Trajectories: A Transplatform Study" (to be published).

9 The exhibition was initially scheduled to last one week. Thanks to support by AXENÉO7, it was added to a program already in place.

10 Contributions by Michel de Broin and Frank Shebageget were subsequently added to this group.

11 Alain Badiou, "Le socialisme est-il le réel dont le communisme est l'idée ?," in L'idée du communisme. Volume 2. Conférence de Berlin 2010, Alain Badiou and Slavoj Zizek (eds.), Paris : Nouvelles Éditions Lignes, 2011, 9-22. Our translation.

12 Jacques Rancière, Figures de l'histoire, Paris: PUF, 2012, 58. Our translation.

13 The video recording of this symposium can be accessed at: www.entrepreneursducommun. net.

14 For more on this, see Dalie Giroux's text in this volume.

15 For a brief overview of the initially proposed memorial and its replacement, see: https://en.wikipedia.org/wiki/Memorial_to_ the_Victims_of_Communism_\%E2\%80\%93_ Canada,_a_Land_of_Refuge (accessed on November 12, 2017)

16 For an insightful summary of the polemics surrounding public historical statues in the US context and the arts community's deployment of counter strategies, see: Gregory Sholette, "Reimagining Monuments to Make Them Resonate Locally and Personally," hyperallergic. com, November 6, 2017. 
17 Juha Siltala, "National Rebirth out of Young Blood," Scandinavian Journal of History, 31(3-4) 2006, 299.

18 Nestor Garcia-Canclini, Hybrid Cultures, Minneapolis MN: University of Minnesota Press, 2005, 134.

19 Tonya Davidson, "Mica, Pedagogy, and Defacement: Learning from Canada's National War Memorial," The Public Historian, 38(2), May 2006, 42-46.

20 Chris Cobb, "War Memorial guard program is designed for dignity," Ottawa Citizen, October 22, 2014, A6.

21 Giorgio Agamben, Profanations, New York: Zone Books, 2007, 77.

22 For greater detail, please see: http://carleton. ca/fass/2016/profane-perambulationsa-public-humanities-experiment-in-theparliamentary-precinct/.

23 George Grant, Technology and Empire, Toronto: House of Anansi, 1969, 17.

24 This essay draws upon critiques of the countermonument I have previously made in "Points of No Return: Cultural Heritage and CounterMemory in Post-Yugoslavia," in Curating Difficult Knowledge: Violent Pasts in Public Places, Erica Lehrer, Cynthia Milton and Monica Eileen Patterson (eds.), New York: Palgrave Macmillan, 2011; and "In Ruins: Architecture, Memory, Countermemory," Journal of the Society of Architectural Historians, 73(4), 2014.
25 James E. Young, At Memory's Edge: AfterImages of the Holocaust in Contemporary Art and Architecture, New Haven: Yale University Press, 2002, 96.

26 Pierre Nora (ed.), Les Lieux de Mémoire, Paris : Gallimard, 1984-1992; Pierre Nora (ed.), Realms of Memory: Rethinking the French Past, translated by Arthur Goldhammer, New York: Columbia University Press, 1996-1998.

27 Pierre Nora, "Between Memory and History," Representations, 26, 1989, 7-24.

28 Pierre Nora, "General Introduction: Between Memory and History," in Realms of Memory: Rethinking the French Past. Volume 1, Pierre Nora (ed.), New York: Columbia University Press, 1996, 1.

29 James E. Young, The Texture of Memory: Holocaust Memorials and Meaning, New Haven: Yale University Press, 1993, 5.

30 James E. Young, op. cit., 2002, 118.

31 Ibid., 96

32 Ibid., 92.

33 Ibid., 119.

34 On post-politics, see, for example, Jacques Rancière, "Introducing Disagreement," Angelaki: Journal of the Theoretical Humanities, 9(3), 2004; and Chantal Mouffe, On the Political, Routledge: New York, 2005.

35 See, for example, Francis Fukuyama, The End of History and the Last Man, New York: Free Press, 1992.

36 Pierre Nora, op. cit., 1996, 2. 
37 Nora's historiography in Les Lieux de Mémoire is thus continuous with his post-political activity in other domains, for example his founding of Le Débat as a platform for "post-partisan" discourse and his refusal to publish a French translation of Eric Hobsbawm's The Age of Extremes. On Le Débat, see Pierre Nora, "Que peuvent les intellectuels ?,' Le Débat, 1(1), 1980, 1-19; on the Hobsbawm non-translation, see Pierre Nora, "Traduire : nécessité et difficultés," Le Débat, 142(93), 1997, 93-95; and on the emergence of post-politics in France, see Michael Scott Christofferson, French Intellectuals Against the Left: The Antitotalitarian Moment of the 1970s, New York: Berghahn, 2004.

38 On the Paris Commune, for example, Marx wrote that "The working class did not expect miracles from the Commune. They have no ready-made utopias to introduce par décret du peuple. They know that in order to work out their own emancipation, and along with it that higher form to which present society is irresistibly tending ... they will have to pass through long struggles, through a series of historic processes, transforming circumstances and men." See Karl Marx, "The Civil War in France," in Later Political Writings, Terrell Carver (ed. ), Cambridge: Cambridge University Press, 1996 [1871], 207. See also Karl Marx, The Eighteenth Brumaire of Louis Bonaparte, New York: International Publishers, 1964 [1852].

39 Michel Foucault, "Two Lectures," in Power/ Knowledge: Selected Interviews and Other Writings, 1972-1977, Colin Gordon (ed.), translated by Colin Gordon, Leo Marshall, John Mepham, and Kate Soper, New York: Vintage, 1997, 83.

40 Tribute to Liberty, "Why a Memorial? Why in Canada?," http://tributetoliberty.ca/memorialwhy (accessed on 12 December 2017).

41 Michel Foucault, "What is an Author?," in Language, Counter-Memory, Practice, translated by Donald F. Bouchard and Sherry Simon, Ithaca: Cornell University Press, 1977, 135.

42 Entrepreneurs du commun, "Monuments aux Victimes de la Liberté," http:// entrepreneursducommun.net/?page_id=122 (accessed on 12 December 2017).

43 This question was taken up and discussed in detail as part of the Journée sans culture, an initiative that (de)mobilized several hundreds of players in the arts and culture milieus. Some of the organizers of this symbolic strike also participated in the Entrepreneurs du commun activities. For more information about this event see: www.journeesansculture.ca.

44 Geert Lovink, Networks Without a Cause, Cambridge: Polity Press, 2012, 46.

45 See my article "Omnia Sunt Communia," Spirale, 253, summer 2015, 6-7.

46 Bruno Latour, "Il n'y a pas de monde commun : il faut le composer," Multitudes, 45, summer 2011, 40

47 For more on this, see Didier Debaise (ed.), Philosophie des possessions, Paris : Les Presses du réel, 2011.

48 Gilles Deleuze, Pourparlers, Paris : Éditions de minuit, 2003, 121. Our translation. 
Biographies 


\section{Érik Bordeleau}

Érik Bordeleau est chercheur au SenseLab (Université Concordia) et collabore à l'Economic Space Agency (economicspace.agency). Il est l'auteur de Foucault anonymat (Le Quartanier, 2012, récipiendaire du prix Spirale-Eva-Legrand 2013) et de Comment sauver le commun du communisme? (Le Quartanier, 2014). Son travail s'inscrit principalement à l'intersection de la philosophie politique, de la théorie des médias, du cinéma et des arts, avec un intérêt marqué pour le tournant spéculatif et le renouveau de la question des possibles dans la pensée contemporaine. Érik Bordeleau est membre du collectif Entrepreneurs du commun.

\section{Mélanie Boucher}

Depuis 2013, Mélanie Boucher est professeure à l’École multidisciplinaire de l'image de l'Université du Québec en Outaouais où, à titre d'historienne de l'art et de muséologue, elle est appelée à se prononcer sur les relations entre l'art et le musée. De 2003 à 2013, elle a mené divers travaux de recherche en conservation, entre autres pour le Musée national des beaux-arts du Québec, et œuvré à titre de commissaire indépendante. En 2014, elle publiait La nourriture en art performatif. Son usage, de la première moitié du $20^{e}$ siècle à aujourd'hui. Son intérêt pour l'art performatif l'a amenée à orienter ses recherches sur le tableau vivant en art contemporain. Dans le cadre du Groupe de recherche et réflexion CIÉCO : Collections et impératif évènementiel/ The Convulsive Collections, Mélanie Boucher poursuit également des recherches sur les usages évènementiels des collections muséales.

\section{Michel De Broin}

Depuis près d'une vingtaine d'années, Michel de Broin approfondit une pratique transdisciplinaire en développant un vocabulaire visuel en constante expansion. Pièce par pièce, les objets qu'il met en jeu sont universellement reconnaissables, bien que leur comportement déjoue les fonctions et usages que l'on tient pour acquis. Les préoccupations inhérentes à sa démarche exercent une grande fascination du fait que l'artiste réussit à établir des relations inédites qui nourrissent un questionnement constant. Les objets remodelés qu'il nous propose laissent entrevoir des mondes de possibilités concrètes. Michel de Broin a reçu le prix Sobey en 2007, et le Musée d'art contemporain de Montréal lui a consacré une exposition bilan en 2013. Il vit et travaille à Montréal.

\section{Edith Brunette}

Édith Brunette conjugue pratique artistique et recherche théorique. L'une comme l'autre s'intéressent aux discours notamment dans le champ des arts -, à ce qu'ils révèlent des forces et des jeux politiques à l'œuvre. Ses projets récents portent entre autres sur la vidéosurveillance (Caméraroman, 2011), la prise de parole en période de crise sociale (Consensus, 2012) et l'agentivité politique des artistes (Faut-il se couper la langue?, 2013, et Cuts Make the Country Better, 2015, en collaboration avec François Lemieux). Ses projets ont été présentés dans différents centres d'art et galeries au Canada et en France. Auteure et chercheure, elle publie régulièrement dans des revues et des ouvrages sur l'art.

\section{Nathalie Casemajor}

Nathalie Casemajor est professeure-chercheure à l'INRSCentre Urbanisation Culture Société (Montréal). Ses travaux portent sur l'action culturelle, la mobilisation citoyenne et les pratiques numériques. Elle est coordonnatrice du Groupe de recherche sur la médiation culturelle et membre de la Chaire Fernand-Dumont sur la culture. Elle a récemment mené à bien un projet sur la présence de la culture et des savoirs des Premières Nations dans Wikipédia et codirigé un ouvrage collectif intitulé Expériences critiques de la médiation culturelle (2017, PUL). 


\section{Rebecca Clare Dolgoy}

Chercheure postdoctorale, Rebecca Clare Dolgoy partage son temps entre Berlin et Ottawa. Ses travaux portent sur la mémoire culturelle du patrimoine bâti en milieu urbain. Elle enseigne actuellement à l'Université Carleton.

Pour en savoir plus sur ses projets, veuillez consulter le site rebeccaclaredolgoy.com.

\section{Entrepreneurs Du Commun}

Formé en 2013, Entrepreneurs du commun est un collectif qui réunit des artistes, historiens de l'art, commissaires, philosophes et chercheurs avec l'objectif d'ouvrir un espace de réflexion et d'expérimentation sur l'hantologie monumentale et les spectres de la liberté. Ses membres fondateurs incluent Érik Bordeleau, Mélanie Boucher, Michel de Broin, Nathalie Casemajor, Gregory Chatonsky, Dalie Giroux, Michael Nardone, François Lemieux, André-Louis Paré, Jean-Michel Ross, Stefan St-Laurent, Bernard Schütze et Adam Szymanski.

\section{Bojan Fajfrić}

Bojan Fajfrić est né en 1976 à Belgrade. En 1995, il quitte la Yougoslavie pour effectuer des études en arts visuels aux Pays-Bas. Diplômé de l'Académie Royale de la Haye, il a bénéficié d'une résidence d'artiste à la Rijks Academy, à Amsterdam, et a participé à plusieurs expositions et festivals, notamment La Triennale-Intense proximité, au Palais de Tokyo à Paris; Theta Rhythm, au Baltic Centre for Contemporary Art à Gateshead; 1966 | Constellations Gaur | 2016, au San Telmo Museum à San Sebastian; STEM TERUG! VOTE BACK!, à De Appel à Amsterdam; The Pleasure of Love, au $56^{e}$ Salon d'octobre de Belgrade; au Festival international du film de Rotterdam; au Festival international du court-métrage d'Oberhausen; au Festival international du film de Vienne; à Doc Leipzig; au Festival du film documentaire Tempo à Stockholm; aux Rencontres Internationales Paris/ Berlin/ Madrid; et au Festival Impakt à Utrecht. Bojan Fajfrić vit et travaille à Amsterdam.

\section{Emmanuel Galland}

Emmanuel Galland travaille comme artiste, commissaire et consultant en culture et communication. Formé en arts plastiques et en histoire de l'art à l'Université de Montréal, il a entamé sa carrière en photographie à la fin du $X X^{e}$ siècle (Mois de la Photo à Montréal, Centre CLARK, Galerie B-312, Séquence, VU, Musée d'art contemporain de Montréal, Musée national des beaux-arts du Québec). II a reçu le Prix PierreAyot (AGAC et Ville de Montréal) et la Bourse DuchampVillon (Centre Plein sud). Ses œuvres figurent dans plusieurs collections publiques et privées. En parallèle, il développe des projets de commissariat, dont Rituel festif-Portraits de la scène rave à Montréal (1997-2000), Les Bricolos (1998), PEUT MIEUX FAIRE - Cahiers d'exercices (2009-2016), STATUER - Les figures du socle (2017- en cours). Impliqué à divers titres auprès d'OBNL culturelles (Centre CLARK, MUTEK, revue ESPACE) au fil du temps; il participe à plusieurs comités et jurys des conseils des arts. Conseiller, formateur ou mentor, il offre un accompagnement créatif et professionnel à plusieurs artistes.

\section{Clément De Gaulejac}

Artiste et auteur, Clément de Gaulejac vit à Montréal. II a exposé entre autres à VOX (Les naufrageurs, 2015) et au Centre Skol (Motifs raisonnables, 2013) à Montréal. Aux éditions du Quartanier, il a publié les titres Les artistes (2017), Grande École (2012) ainsi que Le livre noir de l'art conceptuel (2011); et aux éditions de la Mauvaise tête, Tailleurs d'histoires (2015) et Les cordons de la bourse (2014).

\section{Steve Giasson}

Steve Giasson est un artiste conceptuel qui utilise une grande variété de formes et de médiums (écriture conceptuelle, performance, installation, vidéo...) afin de transgresser les genres et interroger leurs limites. Les notions romantiques d'authenticité, d'autorité et d'originalité sont mises à mal dans sa pratique engagée qui ne ménage ni les emprunts à la vie quotidienne ni les références à l'histoire de l'art-entre hommage et outrage - dans un effort de démythification du processus créateur et de la figure de l'artiste. Steve Giasson poursuit actuellement un doctorat en études et pratiques des arts à l'UQÀM. En 2015, il s'est vu décerner le prix de La Vitrine culturelle, remis à un artiste émergent, et a obtenu une mention du Cirque du Soleil dans le cadre de l'événement Art Souterrain. II vit et travaille à Montréal. 


\section{Dalie Giroux}

Dalie Giroux enseigne la pensée politique à l'Université d'Ottawa depuis 2003. Ses recherches proposent une théorie politique et un plan d'expérimentation interdisciplinaire des formes d'articulation entre l'espace, le langage et le pouvoir dans le monde contemporain. Elle a écrit sur le poststructuralisme, l'histoire des idées, le théâtre, l'université, la territorialité, les questions indigènes, la colonisation et la violence d’État.

\section{Milutin Gubash}

Né à Novi Sad, en Serbie, Milutin Gubash vit à Montréal depuis 2005. Son travail a été présenté au Canada, aux États-Unis et en Europe. Il a notamment fait l'objet d'une exposition au Musée d'art contemporain de Montréal en 2007 et d'une rétrospective coproduite par six institutions canadiennes en 2011-2013 (Rodman Hall Art Centre, 2011; Carleton University Art Gallery, 2012; Kitchener-Waterloo Art Gallery, 2012; Southern Alberta Art Gallery, 2012; Musée d'art de Joliette, 2012; et Fonderie Darling, 2013).

Sa pratique englobe la photographie, la vidéo et la performance et implique souvent la participation de sa famille et de ses amis, appelés à incarner une version d'eux-mêmes dans des feuilletons maison, des réinterprétations historiques et des pièces de théâtre improvisées. Par des moyens simples et des gestes souvent absurdes, Gubash remet en question les suppositions qui sous-tendent notre récit identitaire, notre histoire et notre environnement. En 2016, il a occupé le Studio du Québec à Paris, octroyé par le Conseil des arts et des lettres du Québec.

\section{Andrew Herscher}

Andrew Herscher est membre fondateur de plusieurs groupes de recherche activistes, dont People of Detroit Community Research Collective, Detroit Resists et Commune Research Commune. Ses recherches portent sur l'architecture de la violence politique, la migration et les déplacements ainsi que la résistance et l'autodétermination à travers le monde. Herscher signe entre autres les ouvrages Violence Taking Place: The Architecture of the Kosovo Conflict (Stanford University Press, 2010), The Unreal Estate Guide to Detroit (University of Michigan Press, 2012) et Displacements: Architecture and Refugee (Sternberg Press, 2017). II est actuellement professeur agrégé à l'Université du Michigan.

\section{Peter Hodgins}

Peter Hodgins est professeur agrégé à la School of Indigenous and Canadian Studies de l'Université Carleton. Ses recherches s'intéressent à la politique de la mémoire culturelle au Canada.

\section{Sheena Hoszko}

Sculpteure, organisatrice anti-prison et allochtone, Sheena Hoszko vit et travaille à Tio'tia:ke (Montréal), sur le territoire des Kanien'kehá:ka. Dans sa pratique, inspirée des expériences de détention et militaires de membres de sa famille, elle explore la dynamique du pouvoir en jeu dans les sites géographiques et architecturaux. Hoszko a effectué des études à l'Université d'art et de design Emily-Carr et est titulaire d'une maîtrise en sculpture de l'Université Concordia, dans le cadre de laquelle elle a reçu le soutien du CRSH pour ses recherches sur le féminisme et le post-minimalisme. Elle a présenté des expositions individuelles, entre autres, au Centre Clark et à La Centrale à Montréal; à A Space à Toronto; à Artspace à Peterborough; à The New Gallery à Calgary; à la Forest City Gallery à London, en Ontario; et à la Blackwood Gallery à Mississauga. Elle est également passionnée de science-fiction. 


\section{Marie-Hélène Leblanc}

Depuis 2015, Marie-Hélène Leblanc occupe le poste de directrice de la Galerie UQO à I'Université du Québec en Outaouais. Elle a aussi été directrice générale du centre d'artistes Espace Virtuel à Chicoutimi (désormais BANG) et directrice artistique du centre de production DAIIMÕN à Gatineau. À titre de commissaire, elle a organisé une vingtaine d'expositions présentées dans divers lieux au Québec, au Canada et en Europe. Marie-Hélène Leblanc est candidate au doctorat en études et pratiques des arts à l'Université du Québec à Montréal. Ses recherches portent sur les rapprochements entre l'histoire racontée et le rapport au temps dans les pratiques contemporaines qui traitent des guerres depuis 1990. En 2013, elle recevait la bourse Jean-Claude Rochefort pour le commissariat d'art contemporain décernée par la Fondation de I'UQÀM.

\section{Thierry Marceau}

Thierry Marceau a grandi à Oka. II a terminé des études de maîtrise en arts visuels et médiatiques à l'Université du Québec à Montréal. Ses performances, ses vidéos, ses photographies et ses installations carburent à la mémoire collective, aux images populaires, aux forts personnages, aux costumes, aux spectacles... Vous l'aurez remarqué si vous étiez à VIVA! Art+Action en 2006 et en 2009, au Centre Clark ou au ElvisFest de Brantford en 2007, au Théâtre Plaza, à la Galerie de I'UQÀM ou à la Nuit Blanche de Toronto en 2008, aux funérailles de Michael Jackson à L.A. en 2009, au Mountain Standard Time Performative Art Festival (M: ST) de Calgary en 2010, au Gala des arts visuels en 2011 ou si vous avez vu le premier $1 \%$ performatif au 2-22, à Montréal (2012-2016).

\section{André-Louis Paré}

Depuis décembre 2013, André-Louis Paré est directeur et rédacteur en chef de la revue ESPACE art actuel, éditée à Montréal. À titre de critique et théoricien de l'art, il a publié plus d'une centaine d'articles dans diverses revues québécoises consacrées à l'art contemporain, ainsi que des textes dans plusieurs opuscules et catalogues. II a cosigné trois expositions collectives qui ont été présentées au Québec et en France, et dont la plus récente, intitulée $F E U$, a été présentée à Montréal au printemps 2018. II est membre de AICA Canada et de Transit, un collectif de critiques et de commissaires indépendants. Jusqu'en juin 2016, il était professeur de philosophie au Cégep André-Laurendeau à Montréal.

\section{Projet EVA (Étienne Grenier et Simon Laroche)}

Projet EVA est un collectif artistique fondé en 2003 dans le but de créer des œuvres critiques, expérimentales et transgressives en art numérique. Ses installations et ses performances comprennent des éléments robotiques, électroniques, vidéo et audio, et touchent aux thèmes de la perte et de la restriction. II porte une attention particulière à la question des relations entre les individus, les systèmes informatiques et leurs extensions physiques. L'exploration des moyens technologiques de déprogrammation des perceptions est au centre de la production du collectif, dont le travail a été présenté en Amérique du Nord et du Sud, en Asie, en Europe ainsi qu'au Moyen-Orient.

Simon Laroche est artiste et concepteur en médias interactifs. II enseigne les arts électroniques à l'Université Concordia et collabore avec des créateurs du milieu du théâtre, de la danse, de la mode et du cinéma.

Étienne Grenier œuvre dans le domaine de la culture numérique. À titre de concepteur multimédia, il a collaboré à divers projets dans le champ de l'architecture, du théâtre, de l'éclairage, de la danse et de la vidéo. Il a également enseigné à l'École des médias de l'UQÀM.

\section{Nicolas Rivard}

Nicolas Rivard privilégie une approche interdisciplinaire alliant l'art d'intervention, la performance et l'art conceptuel. Ses principaux centres d'intérêt, inspirés de l'actualité politique, sociale et culturelle, portent sur les nouveaux lieux et formes de l'art actuel comme moteurs de transformation sensible de l'espace social et des interactions qui s'y jouent. Titulaire d'une maîtrise en histoire de l'art et auteur indépendant, Rivard s'intéresse aux formes variées de l'art d'intervention et aux initiatives d'appropriation citoyenne. 


\section{Rosa Iris R. Rovira}

Rosa Iris R. Rovira détient un baccalauréat en sciences sociales, avec une concentration en communication de I'Université du Québec en Outaouais. Également formée en histoire de l'art, Rosa Iris a travaillé comme assistante de recherche pour le projet Espace public de la mémoire. Étude de la controverse sur le Monument aux victimes du communisme (FRQSC). Elle a également été wikipédienne en résidence à Bibliothèque et Archives Canada.

\section{Bernard Schütze}

Bernard Schütze est critique d'art et commissaire indépendant. Ses écrits ont été publiés dans plusieurs revues d'art, catalogues d'expositions et monographies d'artistes. Il a prononcé des conférences dans le cadre de plusieurs évènements artistiques, principalement au Canada et en Europe. D’origine allemande, il vit et travaille à Montréal.

\section{Frank Shebageget}

Natif du Nord-Ouest de l'Ontario, Frank Shebageget (Ojibway) réside présentement à Ottawa. Son travail d'installation porte sur la géographie du bouclier canadien et sur les qualités esthétiques de divers matériaux du quotidien. II recourt à la répétition pour explorer les tensions entre la production, la consommation et l'économie de la beauté, souvent en jouant avec l'incongruité de la production de masse par rapport à l'objet artisanal. Diplômé de l'Ontario College of Art (aujourd'hui l'ÉADO) en 1996, Shebageget a obtenu une maîtrise en arts visuels de l'Université de Victoria en 2000.

\section{Dominique Sirois}

À travers sa pratique caractérisée par un large éventail de médiums (sculpture, vidéo, dessin et image numérique), Dominique Sirois crée des espaces mentaux inspirés de constructions sémiotiques faites de liens et d'analogies comportant des références économiques, esthétiques, archéologiques et numériques. Son travail a été diffusé dans de nombreuses galeries au Canada, dont au Centre CLARK et à Latitude 53. Sirois a réalisé plusieurs projets et résidences à l'étranger, notamment au Center for Contemporary Arts (Glasgow), au Couvent des Récollets (Paris) et à Hangar (Barcelone). Elle a par ailleurs créé plusieurs projets en collaboration avec l'artiste Grégory Chatonsky, présentés notamment au MOCA de Taipei, au CDA Enghien-les-Bains, au Unicorn Center for Arts à Beijing, au Mois de la Photo à Montréal et à iMAL à Bruxelles. Elle vit et travaille à Montréal.

\section{Stefan St-Laurent}

Artiste et commissaire né à Moncton, au Nouveau-Brunswick, Stefan St-Laurent vit et travaille à Gatineau au Québec. II a été commissaire invité du Symposium international d'art contemporain de Baie-Saint-Paul en 2010 et 2011. De 2002 à 2011, il était commissaire de la Galerie SAW Gallery, et depuis 2010, il est professeur auxiliaire au Département des arts visuels de l'Université d'Ottawa. Ses œuvres ont été présentées au Centre national de la photographie à Paris, à Edsvik Konst och Kultur à Sollentuna, en Suède, à $Y Y Z$ à Toronto, à Western Front à Vancouver et au Musée des beaux-arts de la Nouvelle-Écosse. II a été commissaire et programmateur pour de nombreux organismes et festivals, dont le Lux Centre à Londres, la Cinémathèque québécoise à Montréal, le Festival international du cinéma francophone en Acadie à Moncton, Les rencontres internationales Vidéo Arts Plastiques en Basse-Normandie, ainsi que Pleasure Dome, le Images Festival of Independent Film \& Video et Vtape à Toronto. Il a été directeur du centre d'artistes AXENÉO7 à Gatineau. 


\section{Guillermo Trejo}

L'artiste mexicano-canadien Guillermo Trejo vit à Ottawa. II a obtenu un baccalauréat spécialisé en arts d'impression à l'École nationale de peinture, sculpture et gravure de Mexico avant de s'installer au Canada en 2007. Son expérience de la distance et en tant qu'immigrant influencent depuis sa pratique. II possède aujourd'hui une maîtrise en arts visuels de l'Université d'Ottawa et s'implique activement dans la communauté artistique. Ses œuvres ont fait partie d'expositions à la Galerie d'art d'Ottawa et à la Galerie Saw Gallery, ainsi qu'à plusieurs centres d'artistes autogérés au pays, de même qu'en Europe et au Mexique. Trejo a effectué des travaux de recherche pour le Musée des beaux-arts du Canada. II est également professeur à l'École d'art d'Ottawa.

\section{Étienne Tremblay-Tardif}

Étienne Tremblay-Tardif détient un baccalauréat en études cinématographiques et histoire de l'art de l'Université de Montréal, ainsi qu'un baccalauréat et une maîtrise en arts visuels de l'Université Concordia. Ses recherches et sa pratique matérielle traduisent son intérêt pour la densité et la complexité de l'espace social, la théorie critique et les pratiques de l'installation en art visuel. Les notions d'indexation, d'abstraction, de performativité, d'iconoclasme et de commémoration encadrent son travail axé sur l'histoire politique, l'architecture comme infrastructure idéologique ainsi que l'imprimé dans le champ de l'information et dans la culture matérielle. Il enseigne les arts visuels depuis 2015, entre autres à l'Université Concordia, à l'Université de Toronto, au Collège Montmorency, au Collège de Valleyfield et au Cégep de Chicoutimi.

\section{Anne-Marie Trépanier et Alexandre Piral}

Des études de sciences politiques et d'histoire de l'art mènent Alexandre Piral à une pratique interdisciplinaire mêlant écriture et action. Il s'implique au sein de différents évènements en art contemporain, collabore à la réalisation de publications et œuvre au quotidien à l'éducation et la médiation en milieu muséal. Monuments aux victimes de la liberté est sa première participation à une exposition collective.

Anne-Marie Trépanier s'intéresse au langage ainsi qu'aux notions de lecture et d'écriture. Ses projets interrogent les systèmes de représentation de l'information et les rapports entre le politique et l'affect. À travers des activités d'édition, de traitement d'images, de traduction et d'installation, elle développe des formes narratives qui évoquent la production, la diffusion et la préservation du savoir. Son travail a notamment été présenté dans le cadre de Beyond Spectacle-Residency (Gold Saucer Studio, Vancouver), Partage Montréal (La Centrale, Montréal) et Monuments aux victimes de la liberté (AXENÉO7, Gatineau). 



\section{Biographies}




\section{Érik Bordeleau}

Érik Bordeleau is a researcher at SenseLab (Concordia University) and collaborates with the Economic Space Agency (economicspace.agency). He is the author of Foucault anonymat (Le Quartanier, 2012, Spirale-Eva-Legrand 2013 award) and Comment sauver le commun du communisme? (Le Quartanier, 2014). His work focuses mainly on the intersection of political philosophy, media theory, cinema and art, with an interest in the speculative turn and the renewal of the question of the possible in contemporary thought. Érik Bordeleau is a member of the collective Entrepreneurs du commun.

\section{Mélanie Boucher}

Since 2013, Mélanie Boucher is a professor at École multidisciplinaire de l'image de l'Université du Québec en Outaouais where she reflects on the relationship between art and the museum from the perspective of an art historian. From 2003 to 2013 , she held various positions in conservation and research, among others at the Musée national des beauxarts du Québec, and worked as an independent researcher. In 2014, she published the book La nourriture en art performatif. Son usage, de la première moitié du $20^{e}$ siècle à aujourd'hui and, in 2009, the first monograph about Claudie Gagnon. Her interest in performance art led her to carry out research on the tableau vivant in contemporary art. As part of the research group CIÉCO: Collections et impératif évènementiel/The Convulsive Collections, Mélanie Boucher is also pursuing research on the event-based use of museum collections.

\section{Michel De Broin}

For over twenty years, Michel de Broin has been refining a transdisciplinary practice through a constantly evolving visual vocabulary. Piece by piece, the objects he displays are universally recognizable, even though they are put to odd uses that go against the grain of their customary functions. The concerns inherent in his practice are an endless source of fascination due to the fact that the artist proposes unusual relations that persistently stimulate thought. The repurposed objects he proposes provide a glimpse of worlds with real possibilities. He is a recipient of the 2007 Sobey Art Award and a mid-career survey exhibition of his work was presented at the Musée d'art contemporain de Montréal in 2013. He lives and works in Montreal.

\section{Edith Brunette}

Edith Brunette combines artistic practice and theoretical research with a focus on discourses-notably in the arts field-and what they reveal about the political forces at play. Her recent projects explore, among other things, video surveillance (Caméraroman, 2011), speaking out in periods of social crisis (Consensus, 2012) and artists' political agency (Faut-il se couper la langue?, 2013, and Cuts Make the Country Better, 2015, in collaboration with François Lemieux). Her projects have been presented in various art centres and galleries in Canada and in France. She is also an author and researcher who contributes regularly to magazines and books on art.

\section{Nathalie Casemajor}

Nathalie Casemajor is an Assistant Professor at the Urbanisation Culture Société Research Centre at INRS (Institut national de la recherche scientifique, Montreal). Her work focuses on cultural development, citizen engagement and digital culture. She is the coordinator of the Groupe de recherche sur la médiation culturelle and a member of the Chaire Fernand-Dumont sur la culture. Her recent activities include a research project on the presence of First Nations on Wikipedia and coediting the book Expériences critiques de la médiation culturelle (PUL, 2017).

\section{Rebecca Clare Dolgoy}

Rebecca Clare Dolgoy is an Ottawa/Berlin-based postdoctoral researcher. Her work explores cultural memory in built urban environments. She is currently teaching at Carleton University.

For more information about her projects please visit: rebeccaclaredolgoy.com 


\section{Entrepreneurs Du Commun}

Formed in 2013, Entrepreneurs du commun unites artists, art historians, curators, philosophers and researchers with the goal of opening a space of reflection and experimentation focused on Monumental hauntology, like spectres of liberty. Its founding members include Érik Bordeleau, Mélanie Boucher, Michel de Broin, Nathalie Casemajor, Gregory Chatonsky, Dalie Giroux, Michael Nardone, François Lemieux, André-Louis Paré, Jean-Michel Ross, Stefan St-Laurent, Bernard Schütze and Adam Szymanski.

\section{Bojan Fajfrić}

Bojan Fajfrić was born in 1976 in Belgrade. He left Yugoslavia in 1995 to study visual arts in the Netherlands. He graduated from the Royal Academy in The Hague and was the resident of the Rijks Academy in Amsterdam. Selected exhibitions: La Triennale: Intense Proximity, Palais de Tokyo, Paris; Theta Rhythm, Baltic Centre for Contemporary Art, Gateshead; 1966 | Constellations Gaur | 2016, San Telmo Museum, San Sebastian; STEM TERUG! VOTE BACK!, De Appel, Amsterdam; The $56^{\text {th }}$ Belgrade October Salon: The Pleasure of Love. Selected film festivals: International Film Festival Rotterdam; International Short Film Festival Oberhausen; Vienna International Film Festival; Doc Leipzig; Tempo Documentary festival, Stockholm; Rencontres Internationales Paris/ Berlin/Madrid; Impakt Festival, Utrecht. Bojan Fajfrić lives and works in Amsterdam.

\section{Emmanuel Galland}

Emmanuel Galland works as an artist, curator and culture and communications consultant. After studying fine arts and art history at Université de Montréal, he began his career as a photographer at the end of the $20^{\text {th }}$ century (Mois de la Photo à Montréal, Centre CLARK, Galerie B-312, Séquence, VU, Musée d'art contemporain de Montréal, Musée national des beaux-arts du Québec). He is the recipient of the Prix Pierre-Ayot (AGAC et Ville de Montréal) and the Bourse Duchamp-Villon (Centre Plein sud). His works are part of several public and private collections. In parallel, he has developed curatorial projects, such as Rituel festif-Portraits de la scène rave à Montréal (1997-2000), Les Bricolos (1998), PEUT MIEUX FAIRE - Cahiers d'exercices (2009-2016), STATUER-Les figures du socle (2017, ongoing). Over the years, he has been involved in various not-for-profit cultural organizations Centre CLARK, MUTEK, ESPACE magazine) and has participated in several arts councils committees and juries. As a consultant, trainer or mentor, he offers creative and professional guidance to various artists.

\section{Clément De Gaulejac}

Clément de Gaulejac is a Montreal-based artist and a writer. He has exhibited at VOX (Les naufrageurs, 2015) and Centre Skol (Motifs raisonnables, 2013) in Montreal, to name but these. He published the books Le livre noir de l'art conceptuel (2011), Les artistes (2017), Grande École (2012) with éditions du Quartanier; and Tailleurs d'histoires (2015) and Les cordons de la bourse (2014), with éditions de la Mauvaise tête.

\section{Steve Giasson}

Steve Giasson is a conceptual artist who uses a wide variety of forms and media (conceptual writing, text art, installation, video, performance...) to transgress genres and to question their limits. In a practice that does not refrain from borrowing everyday life elements or referencing art history-between homage and outrage-, romantic notions of authenticity and originality are undermined. This process is part of an effort to demystify the creative process and the figure of the artist. $\mathrm{He}$ is currently pursuing a PhD in Études et pratiques des arts (UQÀM). He is the winner of Vitrine culturelle Award for an emerging artist and a Mention from Cirque du Soleil, awarded during Art Souterrain 2015. He lives and works in Montreal.

\section{Dalie Giroux}

Since 2003, Dalie Giroux has been a professor of political thought in the School of Political Studies at the University of Ottawa. Her research focuses on the intersections between space, language and power in the contemporary world. She has written on poststructuralism, the history of ideas, territoriality, Indigenous questions, colonization and state violence. 


\section{Milutin Gubash}

Born in Novi Sad (Serbia) and living in Montreal (Canada) since 2005, Milutin Gubash has presented exhibitions in Quebec, Canada, the United States, and Europe, including a solo show at Musée d'art contemporain de Montréal (2007) and a ten year survey exhibition co-produced by six institutions across Canada (Rodman Hall Art Centre 2011, Carleton University Art Gallery 2012, Kitchener-Waterloo Art Gallery 2012, Southern Alberta Art Gallery 2012, Musée d'art de Joliette 2012 and Fonderie Darling 2013). He was the recipient of the Conseil des arts et des lettres du Québec studio residency in Paris for 2016.

His practice encompasses photography, video and performance, and regularly features the participation of his family and friends, who portray versions of themselves in Do-It-Yourself soap operas, historical rewrites and improv theatre pieces. Using simple means and often absurdist gestures, Gubash reconsiders assumptions about the narratives of our identities, histories and environments.

\section{Andrew Herscher}

Andrew Herscher is a co-founding member of a series of militant research collaboratives including the We the People of Detroit Community Research Collective, Detroit Resists and the Commune Research Commune. In his scholarly work, he explores the architecture of political violence, migration and displacement and resistance and self-determination across a range of global sites. Among his books are Violence Taking Place: The Architecture of the Kosovo Conflict (Stanford University Press, 2010), The Unreal Estate Guide to Detroit (University of Michigan Press, 2012) and Displacements: Architecture and Refugee (Sternberg Press, 2017). He is currently an Associate Professor at the University of Michigan.

\section{Peter Hodgins}

Peter Hodgins is Associate Professor in the School of Indigenous and Canadian Studies at Carleton University. His research focuses on the politics of cultural memory in Canada.

\section{Sheena Hoszko}

Sheena Hoszko is a sculptor, anti-prison organizer and settler living and working in Tio'tia:ke (Montreal), in Kanien'kehá:ka territory. Her art practice examines the power dynamics of geographic and architectural sites, and is informed by her family's experiences with incarceration and the military. She studied at the Emily Carr University of Art + Design and obtained an MFA in Sculpture from Concordia University, where she received SSHRC funding for her research on feminism and post-minimalism. Selected solo exhibitions include Centre Clark and La Centrale (Montreal), A Space (Toronto), Artspace (Peterborough), The New Gallery (Calgary), Forest City Gallery (London, 2018), and the Blackwood Gallery (Mississauga, 2018). She is also an avid sci-fi fan. 


\section{Marie-Hélène Leblanc}

Since 2015, Marie-Hélène Leblanc has occupied the position of director of Galerie UQO at the Université du Québec en Outaouais. Her independent curatorial practice has led her to produce around twenty projects presented in a variety of exhibition structures in Quebec, the rest of Canada and Europe. She has been the executive director of the artist-run centre Espace Virtuel (now BANG) in Chicoutimi and the artistic director of the production centre DAÏMÕN in Gatineau. Marie-Hélène Leblanc is a doctoral candidate in Studies and Art Practices at the Université du Québec à Montréal, where her research examines the connections between the told story and its relation with time in contemporary artistic practices addressing war since 1990. In 2013, she received the Jean-Claude Rochefort grant for contemporary art curating from the Fondation de I'UQÀM.

\section{Thierry Marceau}

Thierry Marceau grew up in Oka. He completed his Master's degree in visual and media arts at Université du Québec à Montréal. Through his actions, Thierry Marceau summons various well known images. Those popular images are put together in strange narratives, resembling dreams and al the freedom they provide. In costumed and occupying centre stage, the artist embodies those multiple images and surrounds himself with extras and other characters to complete the story. His work has been shown in various exhibitions, including "Glissements. Art et écriture" at Galerie de I'UQÀM and "poils" at Joyce Yahouda Gallery. His performance work and his video productions have been shown in many events, such as "Nuit Blanche of Toronto," M:ST of Calgary, VIVA! Art+Action (Dare-Dare and Praxis) and 8 personnages... (CLARK) and he is the first artist to carry out a performance art piece as part of the Quebec 1\% integration of art into architecture policy (at 2-22, Montreal).

\section{André-Louis Paré}

Since December 2013, André-Louis Paré has been the editor in chief of ESPACE art actuel, a magazine published in Montreal. As an art critic, he has published over a hundred articles in various Quebec contemporary art magazines, as well as texts for catalogues and pamphlets. He has co-curated three group exhibitions shown in Quebec and in France, among which the most recent, titled $F E U$, was presented in Montreal in the spring of 2018. He is a member of AICA Canada and Transit, a collective of independent critics and curators. Until 2016, he was a professor of philosophy at the junior college André-Laurendeau in Montreal.

\section{Projet EVA (Étienne Grenier and Simon Laroche)}

Projet EVA is an art collective that was founded in 2003 out of a shared objective of creating critical, experimental and transgressive artworks in the new media sphere. The scope of the collective's artistic activities spans robotics, electronics, video and audio. Projects are connected by the themes of loss and restriction and focus on problematics related to relationships among individuals, computer systems and their physical extensions. Projet EVA's productions have been presented in Asia, Europe, South and North America and the Middle East.

Simon Laroche is an artist and interaction designer. $\mathrm{He}$ teaches Electronic Arts at Concordia University and collaborates on theatre, fashion design, dance and cinema productions.

Étienne Grenier is an artist working in the field of digital culture. He has taught audiovisual interaction design for many years at Université du Québec à Montréal. He has collaborated as a designer with architecture and advertising firms, dance and theatre companies and video producers.

\section{Nicolas Rivard}

Nicolas Rivard favours an interdisciplinary approach that combines intervention art, performance art and conceptual art. His main fields of interest are inspired by current political, social and cultural realities and focus on new sites and forms of contemporary art as engines to palpably transform social space and the interactions that unfold in it. Rivard holds an MA in Art History and is an independent author. He is interested in a broad spectrum of intervention art and in citizen appropriation initiatives. 


\section{Rosa Iris R. Rovira}

Rosa Iris R. Rovira holds a BA in social sciences, with a major in communication, from Université du Québec en Outaouais. She has also studied art history at Universidad de Oriente in Cuba. Over the last two years she has worked as a research assistant for the project Public Commemoration Space. A Study of the Controversy surrounding Memorial to the Victims of Communism (FRQSC). She has also been a Wikipedian in Residence at Library and Archives Canada.

\section{Bernard Schütze}

Bernard Schütze is an independent art critic and curator. His essays have been published in numerous art magazines. He has written various catalogue articles and artist monographs. He has presented talks as part of several art-oriented events mainly in Canada and Europe. Originally from Germany, he lives and works in Montreal.

\section{Frank Shebageget}

Frank Shebageget (Ojibway) is from northwestern Ontario, and currently resides in Ottawa. As an installation artist, his work reflects his continued interest in the geography of the Canadian Shield and the aesthetic qualities of everyday materials. Through the use of repetition, he explores the tense relationships between production, consumption and the economics of beauty, often by playing with the incongruity of mass production versus the handcrafted object. Shebageget graduated with his A.O.C.A. from the Ontario College of Art in 1996, and received his Master of Fine Arts degree from the University of Victoria in 2000.

\section{Dominique Sirois}

Dominique Sirois holds an MFA from Université du Québec à Montréal, where she is currently pursuing a doctorate in art practice and research. Through her practice, which spans a broad range of practices (sculpture, video, drawing and digital image), she creates mental spaces inspired by semiotic constructions consisting of analogue links with economic, aesthetic, archaeological and digital references. Her work has been shown in several galleries in Canada, among which CLARK and Latitude 53. Sirois has carried out projects and residencies abroad, markedly at Center for Contemporary Arts (Glasgow), Couvent des Récollets (Paris) and Hangar (Barcelona). She has also created several projects in collaboration with the artist Grégory Chatonsky, notably at the Taipai MOCA, CDA at Enghien-les-Bains, Unicorn Center for Arts in Beijing, Mois de la Photo in Montreal and MAL in Bruxelles. She lives and works in Montreal.

\section{Stefan St-Laurent}

Stefan St-Laurent, multidisciplinary artist and curator, was born in Moncton, New-Brunswick and lives and works in Gatineau. He was the invited curator for the Biennale d'art performatif de Rouyn-Noranda in 2008, and for the $28^{\text {th }}$ and $29^{\text {th }}$ Symposium international d'art contemporain de BaieSaint-Paul in 2010 and 2011. From 2002 to 2011, he worked as curator of Galerie SAW Gallery, and has been an adjunct professor in the Department of Visual Arts at the University of Ottawa since 2010. His performance and video work has been presented in numerous galleries and institutions, including the Centre national de la photographie in Paris, Edsvik Konst och Kultur in Sollentuna in Sweden, YYZ in Toronto, Western Front in Vancouver and the Art Gallery of Nova Scotia in Halifax. He has been a curator and programmer for a number of artistic organizations and festivals, including the Lux Centre in London, the Cinémathèque Québécoise in Montreal, the Festival international du cinéma francophone in Acadie, the Rencontres internationales Vidéo Arts Plastiques in Basse-Normandie, France, the Festival international du cinéma francophone en Acadie in Moncton, as well as Pleasure Dome, Images Festival of Independent Film and Video and Vtape in Toronto. He was director of the artist-run centre AXENÉO7 in Gatineau. 


\section{Guillermo Trejo}

Guillermo Trejo is a Mexica/Canadian Artist based in Ottawa. He completed his BFA at the National School of Painting Sculpture and Engraving in Mexico City with a specialization in printmaking and moved to Canada in 2007. The experience of immigration and distance has shaped Trejo's work. Since moving to Ottawa, he has earned an MFA from the University of Ottawa and has been an active member of the artistic community. He has exhibited at the Ottawa Art Gallery, Galerie Saw Gallery, and other artist-run centers across the country as well as in Europe and Mexico. Trejo has worked as a research consultant for the National Gallery of Canada. He also teaches at the Ottawa School of Art (OSA).

\section{Étienne Tremblay-Tardif}

Étienne Tremblay-Tardif holds a BA in film studies and art history from the Université de Montréal and a Bachelor and a Master of Fine Arts from Concordia University. His research and material practice develop an interest for the density and the complexity of social space, critical theory and visual art installation practices. The notions of indexation, abstraction, performativity, iconoclasm and commemoration inform his work, dealing with political history, architecture as ideological infrastructure and print in the field of information and in material culture. Since 2015, he has been teaching fine arts at Concordia University, University of Toronto, Collège Montmorency, Collège de Valleyfield and Cégep de Chicoutimi.

\section{Anne-Marie Trépanier and Alexandre Piral}

Political science and art history studies have led Alexandre Piral to a practice combining writing and activism. He takes part in various contemporary art events, collaborates with various publications and is involved in outreach and education activities in museum environments. Monuments aux victimes de la liberté is his first participation in a group exhibition.

Anne-Marie Trépanier is interested in language as well as in the notions of reading and writing. Her projects explore systems of information representation and the relationships between politics and affect. Through publishing, image processing, translation and installation activities she develops narrative forms that evoke knowledge production, distribution and conservation. Her work has notably been presented as part of Beyond Spectacle-Residency (Gold Saucer Studio, Vancouver), Partage Montréal (Powerhouse / La Centrale, Montreal) and Monuments aux victimes de la liberté (AXENÉO7, Gatineau). 
Auteur / Author

Entrepreneurs du commun

Éditeur / Publisher

Codirection AXENÉO7

et Galerie UQO, Gatineau

Coordination principale /

Principal coordinator

Nathalie Casemajor

Comité éditorial /

Editorial committee

Mélanie Boucher

Érik Bordeleau

Nathalie Casemajor

André-Louis Paré

Bernard Schütze

Direction artistique /

Artistic direction

Galerie UQO

Conception graphique

Graphic design

Simon Guibord

Alexandra Nash

Direction de la section exposition

Galerie UQO / Edition of the

UQO Gallery section

Marie-Hélène Leblanc

Direction de la section marche

urbaine / Edition of the urban

walk section

Peter Hodgins

Assistante à la coordination /

Coordination assistant

Rosa Iris R. Rovira

Révision française /

French revision

Nathalie de Blois

André-Louis Paré

Révision anglaise /

English revision

Bernard Schütze

Adam Szymanski

Traduction vers l'anglais /

English translation

Bernard Schütze

Traduction vers le français /

French translation

Nathalie de Blois

Révision d'épreuves /

\section{Proofreading}

Marie-Ėve Marchand

Jean-François Boulé

Impression / Printing

Gilmore

ISBN

978-2-9816925-5-9

\author{
Remerciements \\ Le collectif Entrepreneurs du \\ commun remercie pour leur soutien \\ le Conseil des arts du Canada, \\ Transit-collectif de commissaires \\ et de critiques indépendants, \\ AXENÉO7, le Fonds québécois de \\ recherche société et culture, \\ I'Université du Québec en Outaouais, \\ I'Université Carleton, l'Université \\ d’Ottawa (École d'études politiques) \\ et le Groupe de recherche sur \\ les imaginaires en Amérique latine \\ (GRIPAL).
}

\section{Acknowledgements}

The Entrepreneurs du commun collective would like to thank the following organizations for their support: the Canada Council for the Arts, Transit-an independent curators and critics collective, AXENÉO7, Fonds québécois de recherche société et culture, Université du Québec en Outaouais, Carleton University, University of Ottawa (School of Political Studies) and Groupe de recherche sur les imaginaires en Amérique latine (GRIPAL).

\section{AXENÉO7}

80 rue Hanson

Gatineau (Québec),

Canada J8Y $3 \mathrm{M} 5$

\section{Galerie UQO}

Université du Québec en Outaouais Pavillon Lucien-Brault

101, rue Saint-Jean-Bosco,

Local A-0115

Gatineau (Québec)

Canada J8X 3X7
TRA ISIT

galerie uqo
Fonds de recherch
société et culture

Québec
A)ENE] $] 7$

UQO

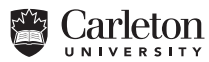

피

uOttawa 